

\section{THE LIBRARY}

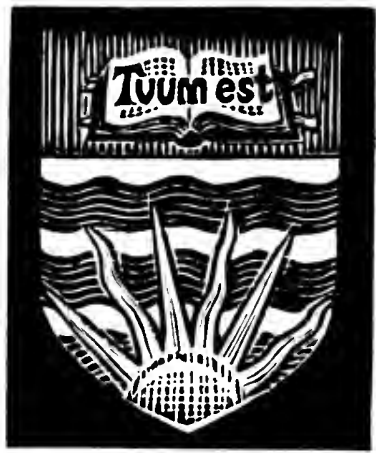

THE UNIVERSITY OF BRITISH COLUMBIA

Gift

Mrs. Bruce Mackedie 




\section{CHAPTERS ON}

MUNICIPAL ADMINISTRATION

AND ACCOUNTING 


\section{Zig the Same Autbor}

THE BANK AND THE TREASURY. Crown 8vo.

RAILROAD PROMOTION AND CAPITALIZATION IN THE UNITED STATES.

Crown 8vo. 


\title{
Chapters on
}

Municipal Administration and Accounting

\author{
By \\ FREDERICK A. CLEVELAND, Ph.D.
}

Director of the Bureau of Municipal Research

LONGMANS, GREEN, AND CO.

91 AND 93 FIFTH AVENUE, NEW YORK

LONDON, BOMBAY, AND CALCUTTA

1909 
Copyright, 1909, by

Longmans, Green, and Co.

The Plimpton Press Norwood Mass. U.S.A. 


\section{PREFACE}

There is a growing appreciation of the fact that democracy, if successful, must be informed. The officer is asked not only to be true to his trust, but also to lay before the citizen a full and prompt account of all matters concerning which the public has a right to know. Efficiency as well as fidelity is demanded of him who is given public position and public honors.

Four fundamental principles of government have been established as a result of experience.

I. Effective coöperation must be based on intelligence.

2. Officers, whether democratic or autocratic, can exercise intelligent direction over affairs only when fully apprised of the business to be administered.

3. Organized democracy can be made effective only so long and so far as it provides the means of regularly and currently bringing before its citizens the facts necessary to the exercise of the best judgment with respect to the fidelity and efficiency of those in positions of trust.

4. When the public may have the same information concerning public affairs that each member has concerning his private affairs there is no coöperative activity required for the highest welfare of a community that may not only be undertaken with advantage to the people but with honor to the trusted corporate servants.

Among the reasons which prompted this publication are the following: There is at present little literature available on the business aspects of government; a considerable number of the papers and addresses have been repeatedly requested and are not available; the papers and addresses 
disclose a historical relation to three important movements, viz.: the work of the National Municipal League; the work of the Bureau of Census; and the work of the Bureau of Municipal Research. The first of these organizations, through its annual conferences, has done much to stimulate interest in the subject of municipal government; the second has rendered invaluable service in bringing together the comparable statistics of American cities and in applying uniform classification to methods of reporting; the third has undertaken a scientific fieldstudy of municipal organizations and of administrative methods and results with a view (I) to informing the public with respect to official acts and community needs; (2) to coöperating with officials in applying to public business, methods that will both fix responsibility for waste and loss of public funds, and insure economy and fidelity; and (3) to developing progressively the power of enlightened public opinion through making available the data necessary to independent judgment, thereby enabling the beneficiaries of government to protect public funds and properties from waste and making citizenship an effective agency.

Although prepared for many popular and successful bodies, differing widely in their special interest to the historian and publicist, and more particularly to the beginner, there may be a significance in these fragments that a systematic treatise could not have at this time of pioneer work and pioneer thinking toward constructive municipal reform.

New YoRk, February, I909

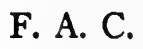




\section{CONTENTS}

CHAP.

I. The Genus Grafter - With Apologies to BACteriology . . . . . . . . . I

The grafter as an institutional parasite - The genus defined - Creatures of environment - How distinguished from other parasites - The two principal families of grafters - The grafter-vendor - The grafter-vendor not a serious menace - The graftertrustee - Some of the most dangerous varieties - The grafter-trustee-guardiansis - The grafter-trustee-insuransis - The grafter-trustee-incorporatus - Grafter-trustee-politicus - Political grafting less profitable than private - The grafter exists because conditions are favorable to his existence - An uninformed society is the grafter's opportunity - Adaptations of the species The modification of conditions - Condition favorable to grafting - Lack of information necessary to institutional control - The limit of control the limit of social organization.

II. How Municipalities put a Premium on GRAFT . . . . . . . . . . $\mathrm{I} 6$

The social induccment to immorality - The institutional inducement to graft - Why servants become dishonest - Dishonesty will continue if encouraged The grafter not to be blamed - The community at fault in not protecting honesty - How the grafter may be exterminated - Not by making war on the individual grafter-Must come through intelligent institutional control - The means of obtaining institutional control.

III. Who PAys for Graft and Inefficient

GovernMent? . . . . . . . . 25

A wrong assumption-Democratic government an agent of the common man - Waste and loss the loss of the common man - A concrete picture of waste vii 
CHAP.

Pay-roll waste - Loss on supplies - Interest on graft - Subversion of revenues - The meaning of infidelity in municipal service - What the amount wasted would buy - The price paid by the poor.

IV. What we do not Know about the Affairs

\section{OF OUR Cities}

The subject of pay-rolls - The purchase of supplies and materials - The keeping of municipal stores Municipal tools and equipment - Municipal repairs and replacements - Municipal revenues - The making of a municipal budget - The future of American cities.

V. The Financlal Management of MuniciPALITIES

Preliminary observations - The method of acquiring funds to be administered - Current funds - Capital funds - Limits of borrowing - Advantages of borrowing capital funds - Reduction of expenditures - Increase of capital by revenue saving - Difference in methods of acquiring capital - Sale of securities and corporate stock - Secured and unsecured loans - The administration of revenues and expenses - Definitions and use of terms - Administrative purposes of revenue accounts Determination of surplus and deficit - Methods of making revenues available - Devices for prompt collection - Delayed collections and temporary loans Hypothecation of revenues and anticipation of tax warrants - Local assessments in lieu of revenues - Application of revenue receipts - Financial economy in administration - English methods - The American situation - Agencies of public municipal education The administration of capital and loan funds - The capital balance sheet - "Capital funds" to be segregated - Capital assets to be protected-Capital assets not for realization - Classification for administrative purposes - Basis for judgment as to capital assets - Idea of protection fundamental - Administration of trust funds - Segregation of trust funds - Management of receipts and disbursements - Cash to be accounted by funds - Methods of financial control Organization for financial control - Revenue control Administrative discretionary control - English and American models - Centralization vs. decentralization - Methods of control under a centralized system Conditions under which decentralization is preferable. 
Constituent elements in municipal governments The budget as an instrument of control - Primary methods of control - Conditions precedent to the effective exercise of control - Electoral control Representative control - Official control - Methods of obtaining information as a basis for exercise of control - Information as a basis for control - The experience of private business-Safeguards of the past negative - Controlling purposes of the budget - Signification of limitation of authority to spend - Use of budget as instrument of positive control - Administrative accounts as means to end-Making of the budget-The preparation of estimates - Collateral inquiry - Publication of estimates of and examination of heads - Formulation of tentative budget and taxpayers' hearing - Supplementary inquiry - The administrative importance of the budget - As related to methods of control - In the audit and vouching of claims Transfers and revenue bond issues.

\section{A Business Man at the Head of a City's} Business Office

A business man's admission of failure - The lesson which his failure carries - Another side to the municipal institution - Why a business man may find himself helpless in a business office - Legal powers with which our business man was clothed - Legal means of enforcing powers - Conditions which have caused the business head to admit defeat - Administrative conditions essential to the intelligent exercise of powers - A system which compels official ignorance - Lack of accounting records showing liabilities - No relation between the accounts in departments and those kept in central office - How organization and methods of administrative procedure may affect municipal debt Doubt may be cast on legality of bonds - Increase of debt through failure to audit - The present audit of claims a farce - Claims passed for supplies without evidence of goods received - Inspections used to further graft - Debt increased by false charges to corporate stock - Extension through contracts - Inability of controller to fasten responsibility for infidelity - Sinking fund revenues may be diverted-General fund revenues may be lost - Conditions under which central control may be made effective. 
CHAP.

VIII. Municipal Accounts - A First Step toWARD MUnicipal ReForM . . . . . IOO

The responsibilities of citizenship under democratic government - Popular control over the public corporation - Ideals of popular control - Failure to provide the means necessary to enlightened political judgment - Doctrines of laissez-faire - Conditions demanding increase in government activities - Provision of methods of control necessary - Accountancy as a guide to intelligent administrative and political control - The data of business - Facts that are not forthcoming - Classes of financial transactions Relations of proprietorship and trusteeship - The progress of accounting science in response to administrative demands - Primitive methods of intelligence - Evolution of modern methods - Developments of methods of control in British cities - First step toward a better corporate procedure - First application to municipalities - Limitations of cash accounts - Application of methods for obtaining better results The lateness of accounting development in America - Our agricultural condition-Recent growth of cities - Chaos and maladministration the result of ignorance - Legal steps taken - Checks and balances - The need for accounts - A first premise to reform - Need for accounts a need for complete and accurate information - Recent steps taken to install complete system of accounts - General adherence to inferior methods - Obstacles in the way of the introduction of better systems of municipal accounts - Divided responsibility - Social inertia - Labor and time necessary to revise old methods - Necessity for professional assistance and advice - The example of the private corporation - The benefits to be derived.

\section{Municipal CRedit and Accounting Refori}

An arraignment of present methods - The basis of credit - Information necessary to exercising investment judgment - The citizen's right to know A prediction of reform - Responsibility of the past - The present opportunity - Pre-consolidation records - Lack of system - Multiplicity of processes The completeness of operative data - Need for central control - Departmental subsidiary accounts - Essentials of a complete system - Magnitude of the task - An expression of confidence - An enlargement of powers - Enlarged responsibility of controller. 
$\mathrm{X}$. The Administrative Significance of a Municipal Balance Sheet . . . . 137

The character of arguments used in challenging its significance - Defects in first form of argument Specious character of the second form of argument The affirmative side of the case - Two classes of problems to be considered - The purpose of accounts and reports which reflect municipal service rendered - The constituencies to be appealed to - Character of intelligence needed - The need for municipal accounts and reports which reflect resources and liabilities - Administrative questions to be answered with respect to resources and liabilities - Questions having to do with expenses of operation - Questions to be answered with respect to the funds provided for acquisition of public properties and equipment - The analogy of private accounting - The protection of municipal properties - The controlling purpose of the balance sheet - Conclusion.

XI. The Administrative Importance of Distinguishing between Revenues and ExPENSES AND RECEIPTS AND DISBURSE-

Ments in Municipal Accountlug . . . 155

What constitutes a complete system of municipal accounts - All data must be collected - Each transaction must be properly classified - All facts must be coördinated around problems of administration Essential difference in the nature of expenses and revenues as distinguished from receipts and disbursements - Two general classes of accounts - The balance-sheet item "cash" - The operation account - Different sources of revenue accounts and cash receipts - Accounting sources of expenses and disbursements - Difference in administrative purposes of the two classes of accounts - Purpose of expense and revenue accounts - Purpose of accounts of receipts and disbursements - Purpose of trust accounts The reason why the "cash book" accounts are the principal ones kept in American municipalities Cash the first asset to be guarded - Single entry the first accounting method - Complete double entry Recent development of administrative accounts Cities on a "cash basis" - Cash accounts do not give operative results - Sound judgment requires operative accounts - How a classified statement of cash 
CHAP.

receipts and disbursements may contribute to improved methods of accounting - Incomplete cash data better than none-Mistaken idea of progress Evidence of the perception of a need - An aid to statistics - The distinction between revenues and expenses and receipts and disbursements essential to administrative efficiency.

XII. The Nomenclature and Phraseology of Municipal Administration and Accounts

Principles determining scientific nomenclatureRelation of accounts and statistics to administration - Problems of ownership - Problems of municipal operation - Problems of municipal trust - Information required to determine ability to meet financial obligations - Information necessary to the preservation of properties - Data pertaining to municipal economy and official control-Nomenclature and phraseology.

XiII. What Constitutes Reasonable Uniformity in Municipal Accounts and Reports

Common functions undertaken by municipalities - Common corporate safeguards - Uniformity in the form of corporate organization of municipalities - Uniformity of classification - Schedule of the committees - The larger work of the committee - Uniformity in principles of accounting - Administrative problems common to municipalities - Essentials common to accounts - Common classification of income and expenses - Common basis for classification of asset and liability accounts - Departmental accounts showing relations of fidelity-Classification of cash receipts - Classification of disbursements - Conclusion.

XIV. Municipal Ownership as a Form of ConTROL

The transition from economic individualism to economic centralization - The newly developed interest in government control - Forms of control proposed - Doctrines of control as applied to cities - Arguments briefly stated - The question of success or failure of municipal industry a conditional one Fundamental considerations - Conditions precedent to successful ownership and operation of enterprises - 
Administrative elements the same whether public or private - Efficiency, economy, and fidelity of government essential to success - Standards for judgment required - The problem of intelligent control - The character of organization - The means for promptly obtaining accurate information - Defective administrative control in cities - The establishment of standards for judgment - Enforcing responsibility for results Conclusion.

XV. Chicago's Accounting Reform . . . 2 I 9

Charles Waldo Haskins - The growth of Chicago - The situation - Attitude of the mayor - The merchants' club - Defects in the system of administration - Financial and economic aspects - Faults in the financial system - Reform in accounts essential - Features of the new system - Monthly reports as a feature - Saving effected - Increase in revenues The work of audit and reorganization-Technical examination - The balance sheet - Classification of revenue accounts - Classification of expense accounts - Conclusion.

XVI. The Systemi of Accounts and Statistics of the City of New YoRk . . . .

The purposes of the investigation - Departments examined - Detailed reports on method - General criticism of the system - Charter provisions for financial control - Charter provisions for executive control - System of accounts needed for financial control - Defects in the system of accounts looking toward financial control - An imperfect account of revenue accruals - Revenue books not in control and not currently balanced - Multiplication of records of expenditure - Failure to provide accounts and statistics needed by the board of estimate and apportionment Defects in the general books and controlling financial accounts - Old accounts not analyzed - Defects in the system of accounts and statistics viewed in their relation to executive or operative control - Duty of mayor to keep himself informed - Inadequacy of office of commissioners of accounts - Methods by which a complete administrative accounting may be obtained - How operative accounts may be controlled - Advantages and disadvantages of each form of control - Mayor handicapped by present charter provisions Criticism and comment on the accounts of depart- 
CHAP.

ments examined - General criticism restated - Bellevue and allied hospitals - The street cleaning departments - Docks and ferries - The Board of Education - Department statistics - Need for better reports.

XVII. Principles Governing the Making of a SCHOOL REPOR

The purpose of making reports - Departmental reports - Reports of subordinates - Special reports What a published report should contain - What a superintendent's report should contain - What a report of a board should contain - Report as to service rendered - Report as to equipment used - Report as to financial relations and results - Premises summarized - 'The content of the "fifth annual report of the city superintendent of schools" - Principal subjects reported on - Chief criticism as to content The report of the city superintendent considered from the standpoint of form - Outline report subject of principal interest - Adequacy of schools and departments of instruction to render service - Organization of the supervising and teaching staff - Principles of exposition - Statements of general results - General exhibit of number and location of schools and departments of instruction - Exhibit of organization for supervision of instruction - Teaching staff by boroughs - Teaching staff by classes and sexes - Comment on special topics - Should lay foundation for board's report Why complete showing should be made - The "fifth annual report of the department of education" - Its form and method of presentation - Defective character of report - Analysis of published report - Content of the report as to service rendered - Defects in report of educational service rendered - Subjects for report on "Educational" service found in the law Subjects for report on administrative service - Exhibit of statistics of school operation - General administration - Content of the report of the board of education pertaining to physical equipment provided for school purposes - Defects in report as to equipment - General subjects of interest with reference to equipment Should establish units of comparison - Content of the report as to financial operation and financial results Defects in financial report - Absence of comparative tables of cost - Statements of revenues defective Lack of harmony with statements of comptrollerStatistics showing relations of economy - Expenses 
incurred - Revenues accrued - Comparison of service rendered to cost - No additional cost if books are kept to give results wanted - No statement of assets and liabilities - Uses to be made of such statements - Conclusions.

\section{Accounting Methods of the Depart-} Ment of Education of the City of New YoRK

Character of organization - Accounting requirements - The accounts kept by the board - Collateral records - Financial statistics - False basis for expenses Information not taken from the accounts - The character of data on which the administration must rely - Memoranda kept by bureaus - Uncontrolled records - Incomplete data - Lack of unity in the system Division of responsibility - Lack of central administrative purpose - Records of one department not coordinated with others - Difficulty in obtaining comparable facts - Lack of coöperation - On the part of the Bureau of Audit - On the part of the Board of Superintendents - Effect on service rendered - Work of schools hampered - Defects in classification - Advantage of uniform classification - Sites - Buildings - Advantage of classified information - Basis of classification - $\mathrm{A}$ restatement of conclusions.

XIX. Administrative NeEd for Accuracy and

UNIFORMITY IN THE ACCOUNTS AND REPORTS OF HOSPITALS . . . . . . .

The hospital as a subject of analysis - Definition of a science - The scientific study of hospitals What may be done by the scientific study of hospital activities - What may be done by the scientific study of hospital administration - The advantages of a hospital science to the individual institution - What may be done by the formulation of an effective system of accounting control.

XX. Eleemosynary Institutions and AccountANCY

Philanthropy and corporate trusteeship - The view of the past - A new idea as to corporate responsibility - The race ideal of accountability and control. 
CHAP.

XXI. An Agency of Citizen Inquiry - The Bureau of Municipal Research . . 346

A bit of Franklin philosophy - The citizen's business - Incidents of corporate trusteeship - Some conditions which suggest inquiry - A statement of principles - The work of the Bureau of Municipal ResearchSystematic inquiry for facts - Methods of making facts available-A constructive programme-"Muck-raking" no part of the Bureau's work - Work of reorganization in progress - Powers unused made operative - Coöperation of official heads - New methods and procedure installed - The need for citizen support - The continuing need for an independent agency of citizen inquiry - Needs of government, business needs - A citizen's business as defined by Governor Hughes. 


\section{CHAPTER I}

\section{The Genus Grafter - with Apologies to BACTERIOLOGY ${ }^{1}$}

THE "muck-raker" has done much to arouse; he has also done much to depress. To the average citizen he does not preach the gospel of hope but of political damnation. His graft descriptions have had much the same effect as would the circulation of a hand book on the ravages of consumption among the inmates of a hospital for incurables. The product of this feeling has been the despair which exhibits itself in the social insanity of the anarchist and the apathy or paralysis of the patriot. The anarchist would apply to institutional infection the firebrand, urging that purification may be accomplished only by wholesale destruction. The average citizen has lost much of his power to respond to patriotic appeal. The attitude of the public toward the "grafter" is much the same as was the attitude of the inhabitants of yellow fever districts ten years ago. Through ignorance they suffered; through ignorance, towns were burned and established institutions were demolished in vain attempts to obtain relief. For this hopelessness of ignorance, science has found a remedy. Through the recognition of a germ, and the study of the conditions favorable to its survival, the scourge of fever has been overcome.

Being asked to speak on the subject of "The Grafter," I come to the Schoolmen of New York to talk in terms

${ }^{1}$ Address to the Schoolmen of New York, November 26, 1906. 
of science - to ask you to consider the grafter as a product of conditions which are favorable to his culture. Let us abandon the attitude of the ignorant and superstitious, and accept the evolutionary hypothesis of the survival of the fittest as a principle of research. Let us not accept as a conclusion that our condition is hopeless, until we have exhausted every resource: (I) in attempting to isolate and describe the grafter in such a way that he may be distinguished from his fellows; (2) to ascertain what conditions are favorable to his survival; (3) to determine who or what is responsible for these conditions and (4) whether conditions may be produced which will cause the grafter to disappear, or to exist in numbers so small and in form so emaciated as to be socially and institutionally harmless.

\section{THE GRAFTER AS AN INSTITUTIONAL PARASITE}

Generically, the verb to graft means to insert or install a rootless bud or detached scion into the succulent fibre of a self-supporting stem in such a manner that the bud or scion thus inserted may feed on the sap which it takes from the foster stalk. Generically a grafter is one who

The genus deknows how successfully to do this - one fined

who, possessing skill in grafting, utilizes it for his own support. Figuratively, the word grafter has been given a social and political significance. The political grafter is one who is an adept at installing a blood-sucking constituency (or himself) on some part of the body politic. Socially he is one who insinuates or weaves himself or his agents into some part of the web of community life in such manner that he is permitted to absorb a portion of communal substance and appropriate it to his own profit.

A grafter has been described as an institutional parasite. 
The figure is instructive. Regarding the genus in this light it is found that, as with all microbes and animal pests, grafters have developed forms as varied as the social and institutional conditions on which they thrive. The corporate forms and institutional groups to which the germ in its many varieties has been found attached

Creatures of environment are both public and private. Nor are the zones restricted to particular occupations. The organic purpose of the institution infected may be business, education, philanthropy, religion, recreation, or general welfare. Institutional development has been one of specialization; it has classified individual workers and increased the limitations and restraints upon them in such a manner as to render them less able to take care of themselves and more in need of organized community protection. With each class or institutional form, we may find a species of the genus grafter which has adapted itself to the conditions there present, enabling the modified species not only to survive but to grow fat and strong. The distinguishing feature of the institutional parasite known as grafter is, that whereas a corporation, as a living organism, is a group of individuals each member of which is coöperating to attain a common end, a grafter (having found lodgment thereon) proceeds to divert the benefits of association to his own selfish purposes. In one sense a grafter is to a corporation what the parasitic insect is to the animal on which it feeds; How distin- in another sense he is sui generis in guished from that he gets his position of advantage by other parasites a deftness unknown to the lower forms of life. Possessed of highly developed reasoning faculties, reckoning on human sympathy and emotion as conditions with which he has to deal, his lust directs his faculties to devise the means by which he may successfully 
play on these sympathies and emotions and through them obtain the consent of the victim before he sucks his blood. This consent is expressed in form of legal and social conventions known as contracts, and therefore consent having been once obtained he claims his reward as a vested right, often using the machinery of justice as an instrument of subversion.

\section{THE TWO PRINCIPAL FAMILIES OF GRAFTERS}

The classes of legal conventions or contracts most frequently used by grafters are two, viz.: those of bargain and sale, and those of trusteeship. The forms of graft that are carried on through contracts of bargain and sale are accomplished either through the vendor taking advantage of individual or institutional ignorance or by reason of individual or institutional weakness. Ignorance

The grafteris taken advantage of by misrepresentation vendor

or fraud. Weakness being relative (he being weak who is unable successfully to compete or protect himself), the superiority which gives to the grafter his advantage is commonly acquired through obtaining from society a legal privilege or monopoly which is protected by society itself as a proprietary right. Deftness is shown in the method of obtaining this privilege or right to take from society a portion of its substance. The right may be attained by bribery and corruption, or it may have developed through the application of the ordinary rules of business. In either case the essential fact is the same - it is the impotence of the individual member of a great complex society, the constraint and comparative weakness of the purchaser, that is availed of by the vendor.

But as a social incubus, the grafter-vendor is not to be feared. The fraud and deception incident to a contract 
of purchase or sale may be readily detected through public inspection and through instruments of popular intelligence such as the press. This has recently been shown in the administration of the pure food law. Complaint is made concerning the exercise of monopoly powers - exactions by so-called Trusts; this again should enlist for society no sympathy. When a great political body The grafter- voluntarily permits its members to be vendor not a mulcted through one of its own corporate serious menace or foster creatures, it is in the attitude of the logger who openly maintains a colony of body parasites in the belief that they are a sign of good health, but whose indifference is the more fully explained by reference to his own ignorance and indolence.

The forms of graft that are carried on through contracts of trust, on the other hand, should be subject for the greatest concern. Graft of this kind is no less than a social crime and should be dealt with as is The graftertrustee

theft or murder. Having induced a victim to confide properties, business or income to his care, the grafter-trustee proceeds in a stealthy, cowardly, sneaking manner to rob the one by whom he is honored and trusted. The faith reposed in him is the cover under which he hides while he saps the life-blood of his quarry. That we may better know the traits of this social parasite, let us study some of the species of the grafter-trustee in relation to the environment which has favored their growth.

Our social structure rests on the family - a convensome of the tional group which has been evolved as a most dangerous means of giving physical comfort and menvarieties tal and moral vigor to the child. In this conventional group the father (not being encumbered with the burdens of maternity) has come to be held primarily 
responsible for obtaining the physical means of support. The mother, in turn, has come to be looked to for the proper administration of the food thus provided - for wholesomeness of home surroundings, for bodily comfort, and for the transmission of race morals and race ideals through which the child may be brought into social harmony with the community in which he lives. In this manner has our society worked out the conditions favorable for health and vigor in the child - favorable to his becoming a useful citizen and to the perpetuation and strength of the race. The family thus constituted is made our underlying social institution for race survival.

Preying on the family we find several specialized varieties of the order grafter-trustee. Pursuant to this race ideal of family responsibility, laws of inheritance have grown up by which, on the death of the male ancestor, the fixed or producing properties acquired during his lifetime, descending direct to the child, are to be held in trust in order that the producing power of this inherited estate may remain unimpaired and its income may be available for support during the heir's minority; on the other hand, the entire personal property or spendable estate is placed at the immediate disposal of the natural or legal guardian for the use and benefit of the

The graftertrustee-guardiansis surviving members. These trusts grow out of the highest and best instincts of humanity - the protection and care for the helpless or immature. Some person must be charged with the responsibility for their execution. Both social convention and the fostering instincts of fatherhood suggest the exercise of extreme care that the trust may be honorably fulfilled. Usually the surviving mother has little knowledge of business. It is in such an environment and in such a position of confidence that one species of the genus grafter thrives. 
Not long since a common illustration of the kind came forcibly to the attention of the speaker. A son who had reached his majority had been made executor for the benefit of himself, his mother and his sister. Immediately upon the estate coming into his hands, he began to plunder it. This was done by various methods; but the one by which the estate suffered most was that of falsely carrying through his trust accounts, purchases and sales of stocks and bonds at prices which caused the estate to lose. These purchases and sales were entirely false and were used as a trick by means of which the title to the personal property of others might be acquired by himself. Whenever he felt that he was in need of funds he ran a few deals through his books. There was no one to watch and no one to ward. The circumstances which made it so easy for him to turn the funds of the estate to his own use need not be described further than to say that even after evidence had been obtained with great difficulty which proved beyond a doubt that large sums had been diverted to the private use of a profligate son, the mother refused to believe that it was possible that her boy could prove untrue, and ascribed the story to evilminded persons reaching for his downfall. This same favoring condition of confiding ignorance is woven about an institution whose trustees, highly respected but neglectful of duties, permit their names to be used to induce the public to trust those who would subvert its functions.

The criminal ingrate who sought to rob his mother the mother who had given him birth, the mother who, while she sustained him and watched over him in illness had learned a confidence born of her own unselfish devotion that now shut her eyes to every suggestion of possible wrong in the boy - the traitorous, insinuating coward, who was successful simply because he was trusted, is 
typical of many an institutional trustee, whose acts have The grafter- brought certain of our insurance companies trustee-insur- and trust companies into disrepute and to ansis

an extent shaken the confidence of the public in institutions of saving and credit. Yet on the integrity of these both our race and national prosperity depends. Another notable aspect of this situation is, that this grafter was not required to make restitution. What is still more significant, the one who was guilty of this crime at that very time and for that matter still is a well-known trustee of concerns dealing with trust estates and conducting business on public credit - a man who, by reason of the reputation of his father and of the prominence of the family whom he had robbed as well as on account of his known fortune, is held out to the world as one eminently worthy of confidence. Relying on his name, patronage is asked for the companies with which he is associated. ' This example is taken as a type of a parasite the existence of which conditions at present favor, and which is permitted to live and thrive by sapping at the vitals of institutions of guardianship and trust.

Applying the institutional principle of broad coöperation to business, our great private corporations have been evolved. Recognizing the private as well as the social advantage to be derived from uses of large capital in the development of continental resources and the employment of labor, our laws have given every encouragement to the organization of stock companies. Those who,

${ }^{1}$ Since this was written millions of dollars have been lost to the institutions with which our trustee was associated. Respected grafters who did much to shake the foundations of credit, temporarily paralyze industry, throw a million men out of employment and cause wholesale distress, are still at large, many of them not even detected, the machinery of justice inert to mark them as even unworthy of further trust. 
by frugality and economy, have acquired a surplus have The graftertrustee-incorporatus found inducement to invest in the proprietary shares of these corporations or in their credit capital obligations. Those who are trained to the business find opportunity for employment of their services, the earnings and profits being divided among those coöperating according to contracts mutually understood by incorporators and employees. But to carry on a corporate enterprise, trustees must be appointed, who, in turn, are held responsible for the selection of officers and operating agents. Into the hands of these trusted representatives and agents are at times given millions of resources representing the combined savings of thousands of people laboring earnestly, honestly, and intelligently for a generation. In the proper use of these earnings is involved the destiny of many thousands more, for future generations. Though honored by such a magnificent trust, it has become common practice for corporate trustees to use their positions and the resources of their institutions for private gain. There are not a few, in fact, whose names have heretofore been held up to the youth of the land as examples of honorable success, whose principal occupation has been that of serving on directorates of corporations which in themselves have given small pecuniary rewards, but through which these same self-sacrificing, patriotic spirits, by methods known to themselves, have managed to divert immense fortunes to their own selfish purposes. Moreover, the officers who have been chosen by these directors have conspired with them to deprive industrial and commercial groups of their earnings.

For purposes of social order and peaceful employment, a public corporation is organized with functions of government. As community interest broadens, as society with 
common ends and purposes expands, occupying large territory, as social advantage and convenience bring individuals together into specialized groups at working centres called cities, as corporate activity becomes Grafter-trustee-
politicus ciety require that this public corporation representing common welfare shall take over the exercise of functions of business which have to do with community service. In this political corporation is represented the highest type of social organization. It stands for the highest and the broadest social concepts; its development has been in response to common inspiration; it is the ideal of common welfare to which individual well-being must be subordinated, the organic motive to which is found in the impulse of patriotism.

In a democratic society political organization takes its form from its democratic prototype, the private corporation. This, too, must act through agents chosen by citizens in whose behalf the trusts reposed in them are to be exercised. For the benefit of the persons residing within the territoral jurisdiction of the city, large funds are contributed in the form of revenues. In the hands of officers these fundsare trust funds. Supplies are purchased. These supplies are purchased for the purpose of promoting the public welfare and are to be strictly accounted for by their custodians. Large sums are paid for labor and personal service. Persons receiving salaries and wages from public funds and who are custodians for properties, stores, and equipment, have in their care the health and the happiness of the community. These things are placed in the hands of municipal officers and employees because they are trusted. Every dollar wasted, every dollar which goes to the one who has a "pull," every supply or material diverted from its proper public use, every hour 
stolen from the municipality by an employee, means more sickness, greater misery and poverty, fewer transportation facilities, lack of protection to the weak, lack of education to the young, loss of opportunity to the individual. BePolitical graft- cause he is trusted the grafter saps the subing less profit- stance of the community. By using a part able than of his ill-gotten gains for purposes of disprivate

play, he poses before the community as the conservator of order, the guardian of public health, the monitor of public education and recreation, and the controller of public convenience; he then asks for a vote of confidence that he may again be placed in a position to abuse his trust. In these several capacities agents of government must also say how private business shall be conducted, and in the exercise of this power they are given charge of the dispensing of privileges in the nature of monopolies by the use of which one set of private individuals and corporations may be enriched, while others may be oppressed or impoverished. It is to this form of grafting that public attention has been especially directed.

THE GRAFTER EXISTS BECAUSE CONDITIONS ARE FAVORABLE TO HIS EXISTENCE

In motive the grafter is anti-democratic and anti-social. So far as he himself is concerned he seeks to pervert both the private and the public coöperative social plan; he is truly individualistic and selfish. Though anti-democratic and anti-social in motive he is not anarchistic - he would not destroy social organization more than the lichen would destroy the oak. Organized society is his opportunity; he recognizes it as his "natural resource." Complexity of organization, comprehensiveness of modern group life and group activity, is the condition favorable. As the great awkward draft horse, when harnessed to a 
plow, is driven frantic by the midget fly, as it is the awkwardness which comes from size acquired through breeding and as it is the restraint placed upon the horse to render him subservient to social coöperative ends which gives the pest his advantage, so it is with the individual (natural or corporate) in modern social organization on which the grafter feeds. The larger and more complex An uninformed the social organization, the greater the need society is the for intelligence about the social institution. grafter's oppor- Does the organization become more comtunity

plex? Without increased knowledge of its affairs, the opportunity for grafting is increased. Although himself anti-social, every inducement may be offered by the grafter to others to be both social and moral. As applied to others he may be most earnest in supporting morality and law. He may teach Sunday school, build churches, and give large sums to charity. He may carefully watch the oppressed lest they may be crushed out in the new social adjustments which are constantly being made; he may do this with all of the consideration with which a shepherd looks after the weakling which later he intends to fleece, but he resents every suggestion that the public should be informed concerning the acts of its agents and trustees; he would preserve no evidence by which the law of trusteeship may be enforced. Evidence is feared by him as the Indian fears famine.

But moral reflection when applied to grafting is misleading. We have erred in not treating him as a creature of environment. If there is ignorance to be dealt with, the responsibility lies not so much with the untutored as with those who are responsible for his training. The street beggar or organ-grinder is not to be blamed, but those who grant the permission and offer the inducement to beg. In this instance we have erred by bringing into 
description terms which import responsibility. We should be more scientific. Discussing the grafter as a social parasite, we should hold more closely to the object of inquiry. Adaptations of Scientifically, we know no right except Adaptations of truth, we know no wrong but falsehood and
the species ignorance. The grafter is immoral, or nonmoral, or anti-moral only so far as we consider him social. Being anti-social, why should our estimate be based on assumptions of morality? To know the grafter as such, we must not look at him through the moral code as a glass, nor weigh him in the balance of justice. To properly describe him we must first isolate the parasite from his environment, then consider him in his relation to it. The fly is not to be regarded as a part of the horse, nor the scale louse as a part of the tree. Looking upon the grafter as a grafter, we can have for him nothing but highest praise. $\mathrm{He}$ has justified his right to survive; he has not only adapted himself to his environment but, human-like, he has in many instances changed his environment in such a way as to make it contribute to his own personal welfare.

The common grafter, whether of the species trustee or of the several varieties vendor, has simply appropriated to his own use and benefit the rich, institutional resources about him. Like the pioneer, he saw before him native resources awaiting only the assertion of rights of proprieThe modifica- torship. Our grafter kings and lords, our tion of condi- enfranchised monopolists and institutional tions

infidels, have done more; they have shaped the institution themselves in such a manner as to bring into their service a wider range of resources and a larger coöperative group; they have adapted the institution to their own ends that they might better support themselves, their children, and their children's children after them. 
THE CONDITION FAVORABLE TO GRAFTING IS LACK OF INFORMATION NECESSARY TO INSTITUTIONAL CONTROL

Moral considerations take us away from the parasite to the institution on which it feeds. Socially, we are primarily interested in the question of the moral responsibility for the existence of the pest. It is not the creature that is to be charged with immorality for adapting himself to conditions which are favorable to his growth; rather the responsibility lies with those who may be held chargeable with those conditions. If, for example, the mother trains her son to believe that he is not to be controlled by social rule; that he is above society; that he is better than his sister; that he is made of superior clay; if he has known no responsibility, no rule other than the satisfaction of his own desire; that he is not held to account; to whom should she complain if this son maltreats her, robs her, and finally, when the burden of protection and support may fall on him, casts her out to be cared for by the society whose welfare she had violated. If a society organized by fathers to comfort the bereaved and support the dependent has carelessly placed large resources in the hands of trustees for safe-keeping without requiring report or account, and without requiring the preservation of evidence by which responsibilities may be fixed, if under such circumstances these trustees shall prove untrue to their trust and to the temptation held out to them to become dishonest - and if on this account society shall be charged with burdens of support which should have been met by natural protectors - shall we condemn the grafter? Or is the responsibility to be placed on the society itself which created and maintained the conditions favorable to graft? Is the leach to be found guilty of breach of confidence for feeding on the water 
rat? or is the parasite seed, cast by friendly breezes in the crevice of the oak, to be condemned for sending its roots into the rich mould? Not the Aphis that has stripped the vine, but the gardener who permits the pest to thrive in his vineyard! By providing conditions favorable to the growth of new swarms of pests he endangers the plants and fruit of his more intelligent and industrious neighbors. These are the persons who are to be held at fault, and it is through forms of publicity by means of which responsibility may be located where it belongs that the application of effective remedy for graft is made possible.

\section{THE LIMIT OF CONTROL THE LIMIT OF SOCIAL} ORGANIZATION

The limit of social organization is the limit of human ingenuity to devise systems of inspection and of administrative account and statistics, which may provide the means for intelligent official direction and for comprehensive reports to the proprietor, the stockholder, or citizen. With such controlling devices adapted to an institution's controlling needs, the power of coöperation is limited only to the advantages to be gained through combining human activity and the power of the human mind to think, to expand, to invent and to execute. Administratively, the power to exact individual responsibility is as great as the power to command the forces which may be utilized for common ends. It is to the perfecting of such devices for controlling intelligence that we must look to rid ourselves of the ignorance and institutional irresponsibility which have been the conditions favorable to the development of the grafter. When society shall have possessed itself of adequate means for currently and accurately informing itself about its own affairs the genus-grafter will be numbered among the occasional and harmless parasites. 


\section{CHAPTER II}

\section{How Municipalities put a Premium on Graft ${ }^{1}$}

Speaking on the question of the social evil, one of the national leaders in charity work announced that he was not interested in the question whose daughter it is, or how many there are at the present moment walking the streets, so much as he was in the social and economic conditions which caused women to choose this method of obtaining a livelihood rather than suffer the hardships and endure the privations which virtue, morality, and social convention require. Given, to an intelligent, comely woman, a choice between ten or twelve hours per day for fifty-two weeks per year on her knees, in rags on a hard, wet floor as a common scrub and a social outcast, with a mere pittance at night for her care and pains given the choice between this and an opportunity to dress The social in- well, to associate with men and women of ducement to intelligence, to become a mistress in beautiimmorality ful private apartments, with servants to do her bidding and with every want supplied (the only price being that she shall forsake the code of conventions which has already marked her as an outcast because she works) - and which career will she choose? Those who despond of better conditions may also ask this question. Instead of hurling its scorching moral thunderbolts against the unfortunate who chooses the easier way, should not society castigate itself? We may at least inquire what it is

${ }^{1}$ Leslie's Weekly, May 4, 1905. 
in the present order of things that makes the path of virtue and honor so difficult for those who honestly toil in our service. May we hope to repress any evil so long as we are causing two persons to break down the barriers that society has thrown around itself for its own protection to each one restrained by forcible detention or benevolent asylum?

We are each members or stockholders in a corporation, the purpose of which is to promote and protect the common welfare. Our Steffinses, our Folks, our La Follettes, our officers of detection and prosecution, our news agencies, tell us that in conducting the business of this corporation there is graft. The common sense of the

The institutional inducement to graft community corroborates the conclusion, but this same common sense has not divined the underlying cause nor suggested an adequate remedy. It is the common habit of the time for public-spirited men to hold up their hands in reproach, to make a few spasmodic efforts to punish individual grafters, then to resign themselves to what may be called the blind workings of political fate. The significant fact is this: that as citizen-proprietors of this corporation, we continue to employ a system which leaves but one of two ways open - either that we ourselves must go the "easier way" and forsake political virtue, or play the rôle of political dependence on those whom we employ and do the bidding of a corrupt organization of our own servants - the grafters. The question for us to ask is not, who are the individual grafters or who are at the moment robbing the public and degrading citizenship to the level of brigandage and criminal association? Rather this - Why should we retain an administrative system which tends to encourage this sort of traffic and association among our public servants? 
Before answering the question as to "How our municipalities put a premium on graft," let us go further with the question as to why dishonesty exists? Why let us ask - why it is that private servants become dishonest. why servants You are about to open a private establishbecome dis- ment. To this end a good servant is honest desired. A neighbor recommends one that for twenty years has been tried and found true. When he engages himself, you say, "I wish to be entirely relieved of homely cares; here are the keys to the silver-chest, to the closet, to the wardrobe; you look after these; do the buying, run the house, and I will furnish the money." On administering your household you take no inventories, require no statements, audit no bills, exercise no supervision, make no inspection of the work. If, after a few months, you find that John has not lived up to his oldtime reputation, whose fault will it be? Is not some of the blame to be attached to yourself? But again let us go further. Suppose that John is only one of a large retinue. Primarily an honest and intelligent man! $\mathrm{He}$ comes to you with the best of intentions. He finds, however, that those around him are careless and faithless. When he plies the Golden Rule they stand by and jeer. With his fellows he finds nothing but discouragement to honest effort and honest dealing. You keep no record of his doings and give him no credit for his pains. When question is raised concerning any transaction that may come to your notice, adverse opinion among his fellows and false report causes suspicion to rest on him for the perfidy of a band of thieves and loafers that you have trained in the ways of deception. So long as your present administrative methods continue, his only protection must lie in the friendly offices and in the good opinion of his fellow servants - his employer affords him none. 
If, under such circumstances, John becomes degraded, what is the remedy? Will dishonesty be rooted out of your service by discharging or punishing John? Will reform be instituted and change of personnel when all of the conditions remain favorable to dishonesty and unfavorable to integrity and efficiency of service?

In private business circles the complaint is heard that employees cannot be trusted as in the good old days that men are less upright. Who says this fails to grasp the meaning of modern commercial and industrial progress Dishonesty will and conditions. Not that men are less continue if en- honest, but that more is required of them. couraged

Under the old régime, every transaction went on in plain view of the proprietor, or, if not in his presence, he was so far familiar with his little stock in trade that he would at once detect a loss. The system was one of close and constant inspection and "personal count." Business grew; it came to be too large for the system. The "personal count" of the proprietor was no longer possible and his direct supervision of each transaction was lost. When a private undertaking has reached this phase of development, then one of two results must follow - either the "personal count" must be supplemented by a system of "record account" that will reflect the acts and responsibility of each employee and protect him against the dishonesty of others, or the business itself will soon become numbered among the scuttled and stranded derelicts. If a merchant fails to encourage honesty and efficiency in his service, and if perchance his employees become careless of his welfare when he has shown himself indifferent to theirs, he may well reflect that the times are not what they were when the affairs of each man and the acts of every citizen were recorded in the intelligence of the whole community. 
We turn now to municipal affairs. Yes, there is graft. But who is primarily responsible for it? Does a banker condemn society for the loss of a bag of gold that has been carelessly left over night on the sidewalk? Not society, The grafter not to be blamed but the teller or clerk who in the "record account" is found short, and whose duty it was to put that particular bag of coin into safe-keeping! The stockholder of the bank may not witness a single detail of business transacted by his institution. He may not count the cash nor thumb over the securities, but he knows that every coin, security, voucher, and paper is accounted for. How? By having a system that so thoroughly records the acts of every servant that "the very hairs of his head are all numbered," not only that no harm may come to the stockholder, but that no harm may come to his employee.

In government we have thrown safeguards to the winds. Yes, the treasury has come to be protected against direct robbery; generally speaking, disbursing officers and clerks are true to their trust; we have given to the public and to tellers of cash adequate security by installing a system of strict "record account" for funds The community and for reccipts and disbursements. But at fault in not in every public contracting relation, in every protecting honesty position requiring the exercise of official discretion, in every administrative relation having to do with economy either of service or of public resource, we are without system and without "record account" which will aid our responsible agents in the direction of our affairs, protect them against infidelity from within or piratical enterprise from without. Such graft as exists is the direct result of the system by which we encourage our public agents to become dishonest, and discourage every effort and ambition to build up in 
our public institutions an esprit de corps and a morale that will hold the object of their creation (public welfare) above the claims of individual greed.

Even in the best organized and best equipped municipalities there seems to be a lack of information which either will aid the officer in the performance of duty or enlighten the citizen (the stockholder) as to the doings of his agents. A few American cities have installed systems of "record account" from which this information may be had, but, generally speaking, in these cities, little use is made of the system other than to strengthen financial control. Even the devices which have been installed in response to a popular uprising or a spasm of civil virtue have been left for execution to those who have been trained to defeat all efforts directed toward control. The citizen proprietor through whose effort the new method has been installed has failed to inform himself with respect to the integrity of its use or even to utilize the data obtained for civil ends. The result is degeneration of the system installed to the old level or as nearly to this plane as is considered safe.

Under the best of systems of government accounting the so-called reform municipal officer as well as the citizen has failed to appreciate the difference between "financial control" and "general administrative control." The first has to do with matters of budgetary estimates, revenue provisions, protection of funds, and the like. These matters are for the council, the finance committee, and the comptroller. The direction to be given to the many departments, the service to be rendered to the public, matters of municipal economy and efficiency, all of the operative activities, require effective organization, intelligent direction, constant supervision, rigid inspection, and honest endeavor on the part of every officer and employee 
in the service. These are the functions with which the mayor and the chiefs of departments are charged.

How may the mayor know whether the chief of the police department is competent to command the forces on which we depend for protection, unless he may have a complete record of the operations of the department laid before him for consideration, and standards of comparison set up by which competency may be gauged? How may the superintendent of streets know whether those in his service are giving honest return in service rendered? How may we as citizens know whether we are paying too much for light, for paving, for water, for municipal supplics? So long as questions of this kind remain unanswered, so long as we have no method established by means of which this information may be correctly and regularly brought before us, so long as we have no exact basis for judgment as to competency or integrity, just so long will we be putting a premium on official incompetency and public graft. What we need is a thorough system of municipal "cost keeping" together with a comprehensive system of centrally controlled "administrative accounts." More than this: These records and results should be translated into simple, plain English and currently reported to citizen-stockholders of the corporation organized to protect and foster the common weal. Until this is done we as citizens are putting a premium on graft, we are providing the conditions for a constantly increasing infection that must corrupt, degrade, and ultimately destroy the ability of the people to coöperate for their own protection and welfare.

\section{HOW THE GRAFTER MAY BE EXTERMINATED}

The rule of right when applied to the elimination of infectious disease proceeds from social necessity - a neces- 
sity which is itself a condition precedent to the extermination of the disease-producing germ. Bacteriological experiment by analogy teaches us that we may not protect the body politic from parasitic growth by making war Not by making on the individual offender or on a particular war on the colony of grafters. The only social reason individual for applying a germicide to a particular grafter

germ or ingrafted colony of germs is to save the one who has fallen a helpless victim of social neglect. Social protection must look to broader results - the extermination of the whole community of parasites or the rendering of them weak and harmless if perchance any of them may find lodgment in the system of the individual.

A crowded city cannot protect itself from the scourge of typhoid by perfecting methods of medical or clinical treatment to be given to those who have already been poisoned by the germ. Medicine may alleviate suffering and prevent the death of the individual who has been poisoned. The maintenance of the free hospital is in recognition of duty toward him who has been rendered incapable of protecting himself in a society that breeds infection; but science has long since demonstrated that Must come so long as conditions prevail favorable to through intelli- typhoid culture medical treatment will not gent institu- suffice. Through scourges of "Black tional control Death," Asiatic cholera, and yellow fever we have learned that the only way to successfully protect society is by enforcing a method of living which will protect the individual from disease, - i.e., the remedy of intelligence is sanitation and disinfection as a means of controlling the conditions favoring germ culture. The remedy for graft must have to do with institutional methods, rather than with the treatment of individual cases. The method must be one of intelligent control over the func- 
tions of public corporate activity, and the enforcement of responsibility for its proper direction.

\section{THE MEANS OF OBTAINING INSTITUTIONAL CONTROL}

The larger the institution and the richer the institutional returns the greater has been the inducement to graft. As before suggested, the social advantage to be attaincd through combination has given rise to corporate privilege, the use of which for common ends is dependent on corporate trustees and agents. Intelligent control can come only through a complete understanding of the facts. There has bcen a rapid development in institutional responsibility and trust rclations without a corresponding development of the means of institutional intelligence whereby the public servant and the trusted employee may be held to strict account. As institutional affairs have become too large for personal inspection, for lack of cvidence direct control over integrity and administrative efficiency has been lost. To cope with this situation it is nccessary that improved methods of administrative accounting may be devised, - methods of obtaining currently information as to the presence of conditions favorable to graft - that the institutional parasite may be rendered incapable of harm. On such conditions must depend our ability still farther to expand industrial, commercial, and other forms of institutional coöperation without destroying the end or purpose for which this coöperation is sought. 


\section{CHAPTER III}

\section{Who Pays for Graft and Inefficient Government? ${ }^{1}$}

IT is commonly assumed that the taxpayer pays for graft and inefficient government. This fallacy has been skilfully used and taught by many a self-seeking demagogue urging support for an officer or for an organization which has abused public trust, wasted public funds, and misdirected the energies of government in granting privileges and monopolies for their own enrichment. What is more to the point, in provoking class feeling, in stim-

A wrong assumption ulating prejudice, the argument has been successful. Through dispensing a small percentage of the funds subverted, as gratuities to the unfortunate and as evidence of personal interest in their welfare, the grafter has succeeded in holding himself up in favorable contrast with the man of wealth. This properly prepares the mind of the victim for the conclusion that the man of wealth and not himself is the one who suffers from political infidelity. In fact it has come to be believed by a considerable portion of the community that it is virtue rather than vice to steal from the government. Even the courts seeking popular applause have refused to consider such cases as stealing water and conversion of goods belonging to a municipality - they have gone so far as to reprimand officers who have placed public thieves under arrest.

Democratic government is the agency of the common

1 New York Sunday World, November 29, Igo8. 
man. It is the instrument created for the protection of the individual against social and economic conditions which, without this protection, would threaten his welfare - possibly his existence. Anything which tends to undermine government support, subvert its resources, or render its service inefficient, deprives the citizen of the protection and advantage which otherwise he might have. The man who pays taxes does not pay for bad

Democratic government agent of the common man government; he pays for good government. He pays for protection to the community; for the protection of each member alike, whether taxpayer or non-taxpayer. If government is not efficient, it is not the taxpayer as taxpayer who suffers, but each individual member of the community as the beneficiary of public funds.

The subversion of revenues, the taking of public goods or the theft of time and service which is paid for by the municipality is a direct loss to the weak rather than to the strong. This is necessarily so for the reason that persons of wealth can protect themselves; they have the means to provide themselves with wholesome food and wholesome surroundings. For these, persons less fortunately situated must depend on government regulation and control. Their hope lies in efficient government and the most painstaking care in the application of public resources to public use.

Even considered in its purely business aspects, bad government is relatively of unimportance to the taxpayer as a taxpayer. Most of the taxes are taxes on real estate, and taxes on real estate are usually shifted to the consumer. Assuming that land taxes are equitably distributed - with increased taxes come increased rents; with increased rents come increases in the retail prices of goods; increased prices are paid by those whose com- 
fort is to be served. Generally speaking it is found that retail prices of goods vary directly as do rents and taxes. Increased cost of government, therefore, ultimately falls on the consumer rather than the taxpayer, for the reason that the ratio of consumption to income decreases as individual wealth increases.

But to get the matter clearly before us, we must consider another side of the problem. Aside from the increased cost of living which increased taxes entail, what is lost by bad government and whose loss is it? What is the loss entailed on the individual who while a child suffered from tuberculosis of the spine and is left a cripple for life? What is the loss entailed on a man, his family, the community by virtue of the fact that when a boy he had no educational advantages - that he is unable to read and write? What is the loss entailed on the Waste and loss individual who in youth has been forced the loss of the to live among the immoral and criminal common man and who has become a pervert or a social and political outcast? What is the distress entailed upon a family through sickness and death from preventable diseases? What discomfort, loss of vitality, and lowered earning power result from living in unsanitary tenements, in dark rooms, in crowded and badly ventilated apartments? What happiness is destroyed through fear of violence or lack of police protection in districts where the vicious live? Who pays for the babies who die from infected milk? Who suffer from the germladen filth of the streets? Who are the ones who are the victims of the gambler, the seducer, the vendor of adulterated foods?

From any point of view, it is not the one who directly pays the taxes who pays either for the direct or indirect cost of waste of public funds or inefficiency of service. 
It is the man or woman who is handicapped. It is the child who in the future will be handicapped; the one who to-day is flattered by the personal attentions of the political infidel; the one who eats Christmas turkey - the gift of the despoiler to him who is despoiled. These are the ones who are paying in money, in health, in happiness, a hundred times more than the great taxpayer whose better fortune is urged as a reason why the unfortunate should still consent to support what has been so flippantly called "honest graft."

\section{A CONCRETE PICTURE OF WASTE}

The cost to the people of the city of New York may not be appreciated without reference to concrete facts. First let us ask ourselves how much public income is subverted by breach of trust and inattention to duty. Our budget this year is $\$ 140,000,000$. This was the amount Pay-roll waste provided for the beneficial use of residents that the people for whose benefit this fund is set apart would permit from $\$ 30,000,000$ to $\$ 50,000,000$ annually to be diverted from its proper public use. But is not this just what is happening? Approximately $\$ 80,000,000$ per year is spent for salaries and wages. Assuming that there is no waste in the salaries and wages of teachers and firemen, would it be too high an estimate to say that there is a waste of twenty-five per cent of the other pay-roll cost of government? Is $\$ 12,000,000$ per annum too high an estimate of the loss due to collusion, idleness, and inefficiency? Assuming that this amount is lost, is not the theft of $\$ 12,000,000$ of time and service just as criminal as the theft of $\$ 12,000,000$ from the treasury?

New York buys probably $\$ r_{5}, 000,000$ worth of supplies and materials per annum for current operation and 
maintenance. Yet it pays higher prices than are paid Loss on supplies by persons who buy at retail for a small family. It buys in wholesale quantities but does not obtain wholesale rates. It pays cash but does not get either trade or cash discounts. It takes millions of goods into stores without holding any one to account. It has little protection against deliveries short in weight and inferior in quality. It is safe to say that approximately $\$ 5,000,000$ of every $\$ \$_{5}, 000,000$, spent for supplies and materials is worse than wasted. New York buys from five to twenty-five millions of dollars of real estate each year. In the light of what is already known of the practices associated with such purchases, is it excessive to say that it pays double the amount that a private person would pay for the same properties? When some one by a process of unfair dealing deprives the city of its funds, and by collusion converts them to his own use, should we not ask ourselves the question, What is the significance of such malpractice?

The city pays $\$ 30,000,000$ per annum interest on debt and $\$ 20,000,000$ for redemptions. When we consider its real estate purchases, its construction contracts, its methods of using corporate stock to cover up transactions that are not to be reported in budget estimates, is it too much to say that one-half of the debt of the city represents the tribute of the poor to grafters and to those

Interest on graft who profit from the city's inefficiency? Assuming that this is approximately true, the city is paying over $\$ 20,000,000$ per annum as a current charge for something that it never obtained, besides being deprived of several hundred million dollars' worth of needed equipment.

Recent investigations have shown that the city is not 
getting all the revenue to which it is justly entitled. The same organized band of grafters in the government

Subversion of revenues

and out who are conspiring to divert the funds which are held in trust for the common welfare are busy at work diverting the revenues before they reach the municipal treasury. It would appear by conservative estimate that the city is deprived of not less than $\$ 5, \infty 00,000$ of its revenues each year, and that the distribution of favors is very wide.

THE MEANING OF INFIDELITY IN MUNICIPAL SERVICE

Let us stop and consider what all this means. What would $\$ 12,000,000$ per year, if used to pay for honest service, do to relieve sickness and distress, preserve order, What the encourage morality, educate the young, and amount wasted contribute to public welfare and happiness? would buy What would $\$ 5, \infty 00,000$ spent for supplies and materials do to support adequate service if devoted to the best uses of the community? What would $\$ 20,000,000$ or such sum as may represent the budgetary tribute of the present to the graft of past years, paid annually as interest and retirement of debt, mean if applied to the building of subways, the improvement of the streets, the equipment of parks and playgrounds? What would $\$ 300,000,000$ of indebtedness, or such sum as may have been incurred, which represents the margin of graft in the purchase of real estate and in construction contracts, mean if fairly expended for added school buildings, libraries, museums? What would $\$ 5,000,000$ of revenues sacrificed annually to organized graft do if used to the highest interest of those who need the protection of government?

Whether we be right or wrong in the estimates of the financial cost to the community of infidelity and in- 
competence in municipal service, the cost measured in human lives, in sickness, poverty, misery, and crime, can The price paid never be estimated nor accurately described. by the poor And this price is largely paid, not by the rich but by the poor, those persons who are constantly appealed to for support by the institutional parasites who are sapping the resources of the body politic. What is not understood by the victim of private greed in public station is that every dollar diverted from public use is a support withdrawn from community effort to protect itself against disease and discomfort due to the conditions under which the people of a great city must live; that while taking away the supports, the grafters would divert attention from the consequences of criminal selfishness, by making it appear that his own gains are derived from those who can afford to be victimized. 


\section{CHAPTER IV}

\section{What We do not Know about the Affairs of our Cities $^{1}$}

IT is frequently said by municipal officers who are striving to do their duty, as well as by persons interested in government, that a city may never hope to do business with the same fidelity and efficiency as do private corporations. The conclusion is not well founded. The time has come when the real causes of infidelity, waste, and inefficiency are being considered. It is beginning to be appreciated that no great business can be successfully conducted without exact knowledge conThe results of cerning its details being brought to those who are responsible for direction and control. It is coming to be appreciated that this is just as true of public business as it is of private affairs; that it is just as true in the management of municipal estates and the administration of funds in which an urban community has a beneficial interest as it is of the estates and funds of life insurance companies, savings banks, and other concerns. The affairs of our cities are clouded in darkness, so long continued and so black that it is only after long continued groping that any knowledge of conditions can be obtained. There cannot be intelligent or efficient administration while such a state of affairs exists. The citizen, the stockholder, the responsible officer, is asking for light to guide him.

1 Address before the League of American municipalities at its rath Annual Convention held at Omaha, Nebraska, September 30, rgo8. 
Let us make these generalizations more concrete. Approximately fifty per cent of the annual budgets of cities in the United States, or about five hundred million dollars per annum, is spent for salaries and wages. It is a common complaint that municipal employees are not displaying the same zeal for the city that they do for themselves; that they do not render the same character of service - are not as efficient; and that work is not as economically done as in private corporations. What is the method usually employed in cities for keeping before

The subject of pay-rolls

the eye of the responsible officer and the public, honesty and efficiency of service?

What is the method of keeping time and recording service in your own city? What means have you for fastening responsibility upon the individual employee, the timekeeper, or the foremen for a correct statement of the time actually spent and the character of work performed in the city's service? Upon what evidence of service is your pay-roll based? Even assuming that the time is correctly recorded, what method is employed in your own city for ascertaining whether or not the pay-rolls are properly prepared, and that the charges entered thereon are just claims against the city? Are the pay-rolls audited, or are they simply passed upon the signature of some one who knows nothing of the facts and therefore cannot be held responsible for misrepresentation? What would it mean to your city if such responsibility could be fastened, i.e., if the city could be protected against incompetence and waste with respect to fully onehalf of its budget? Is it too much to assume that fifty per cent of appropriations made in your city for salaries and wages is wasted through inattention to the city's business by those who are employed in its service? Is not the theft of time and service quite as much against public 
morals and public welfare as the misappropriation of money from the treasury, or the purloining of goods from a municipal storehouse? Is not the moral effect upon the employee just as degrading to steal time as to steal money and goods? What would a more effective application of five hundred million dollars per year spent in salaries and wages mean - in public health, in public order, in public convenience, in public education, and all that makes for public wellbeing? Does not success in your own private affairs depend upon knowledge of the details of business? Have you as citizen or officer a knowledge of the details of business within your own city? Is there any adequate means in vogue in the city whereby you may inform yourselves concerning these details, in so far as they pertain to the character of service rendered by municipal employees?

Second only in importance to the loss to the city for dishonest and incompetent service is loss to the city through contract for supplies and materials, and the handling of these supplies and materials after they have been received. These purchases, together with contracts for repairs, will The purchase probably make up between twenty per cent of supplies and and forty per cent of your annual budget. materials

In our large cities, the supplies and materials purchased amount to millions of dollars per annum. The city is usually a cash customer. It buys in larger quantities than any private consumer, and therefore should be able to obtain the benefits of wholesale or manufacturers' prices, with both trade and cash discount. What is the experience of American municipalities? On account of the method employed in making purchases and in making settlements for purchases, does not your city usually pay higher prices than any one else in the market, and receive inferior goods? Do you know whether your 
city receives short deliveries? Does your city avail itself of either trade or cash discounts? Is it not a proper subject for inquiry as to the definite causes which bring about such a result? What proportion of the goods purchased in your own city are purchased on competitive bids? In the preparation of proposals for bids, are the specifications so made that the wholesaler and manufacturer or other legitimate trader may be protected; or are these specifications so loosely drawn that some person in the municipal service who wishes to favor one contractor, and ruin another, may do so? Did you ever examine into the question whether these proposals conform to well-known trade specifications? If you have, it is safe to say that taking the contracts of any ten different departments of the city, for similar goods, it would be difficult to recognize the character of any standard article from the description. Is not this one of the reasons why you do not have real competition? Is not this a detail worthy of your attention?

Moreover, has there been any attempt made in your city to standardize the character of purchases to be made, so that wholesalers and manufacturers may prepare themselves for meeting the municipal trade demand? If you have hospitals, have you standardized your China and Queens ware, so that instead of having twenty or forty different sizes and qualities of dinner plates, you have two or three standard sizes and qualities which lend themselves to a definite trade specification? For purposes of preparing bids for the purchase of lumber, have you, in your city, sought to standardize the different grades and sizes to be advertised for and purchased? Have you established definite and well-known trade standards for coal to be purchased? Would not attention to such a detail mean much in bringing you to an honest and honorable 
trade basis, as well as save you much money, or increase the efficiency of your service? What have you done toward informing yourselves as to prices current? What have you done to make prices current available for the purpose of informing the officer who is charged with the making of contracts and the letting of bids, or the auditor who is charged with the responsibility for passing on the justice of claims presented for payment? In a large city this would require the services of a cataloguer, possibly a woman, who would be paid at the rate of perhaps twenty dollars per week. Assuming that competent service of this kind were obtained, would not a city which must purchase millions of dollars of supplies profit by such an administrative detail?

Again, assuming that the city has properly protected itself from the point of view of standard specifications as a basis for bids and by making provision for obtaining knowledge as to prices and availing itself of trade discounts, this still falls short of fair and honorable dealing; this does not protect the wholesaler or manufacturer in competition with the middleman with political influence who is permitted to make deliveries of inferior quality and short-weight, or possibly to render two bills for the same article and receive payment on each. What provisions have you in your city for knowing that the The keeping of goods purchased by the city are up to the municipal standard required, and that the quantity stores actually delivered corresponds with the amount stated in the invoice? In case you have an adequate method of protecting the city against short and inferior deliveries, then what provision have you for knowing that goods delivered have reached the uses for which they are intended - in other words, whether or not they have been diverted to private instead of public 
uses? Have you a system of inspection and a method of store account under proper accounting control which will hold the storekeeper or custodian of the goods to the same accountability as is the treasurer held for the cash received and disbursed? From the point of view of public morality and institutional efficiency, is it not just as important to control a million dollars worth of goods as it is to control a million dollars of cash with which the goods are to be purchased? Are iron pipe and brass fitting being taken from your municipal pipe yards and repair shops without anybody being held to account? Are loads of coal and barrels of sugar and sacks of flour (for which the city is paying) being delivered to the houses of private individuals? If goods are being diverted from their proper use, if weights are short and qualities inferior, if the manufacturer and wholesaler engaged in legitimate business are being driven out of competition, and no one but a straw-trader or an intermediary finds it profitable to deal with the city, should not some one be held criminally responsible for these acts? These are details of business worthy of attention in private business - in fact to neglect them would mean failure; should they not have the attention of those interested in public business? Or, is it still to be accepted that the taking of goods or the wasting of service belonging to the city is only a practical joke to be winked at?

A considerable portion of the municipal estate is in the form of tools and equipment. Many of these are of such a character as to be easily lost or disposed of. The cost of replacement probably amounts to at least five per cent of the annual budget. This in a city like New York would mean several million dollars of annual expenditure. In the smaller cities the expense and capital outlay would be proportionately less. May we not ask ourselves what 
provision is being made for knowing that this necessary equipment for municipal service is being properly cared for? How do you know that a large part of the cost is not

Municipal tools and equipment for the replacement of tools and implements that have been diverted to private use? Does the city charge to the employee or to the foreman the tools and instruments which are placed in his hands? When requisitions are made for tools and instruments to replace those which are alleged to be worn out, does the city require that the old tool shall accompany the requisition before it will be honored? Even old tools are valuable; does the city realize what it should on its scrap? Private institutions have found that insistence on such small details has saved them hundreds of thousands per annum - in fact has reduced their tool account to fifty per cent what it had been when no account was kept and the old tools were not required to be returned. Is it to be expected that a municipality can get good business results and can expect fidelity of service when they do not take the ordinary precautions used in private business?

Some of our cities operate repair shops which employ hundreds, even thousands, of men. In these shops all Municipal re- kinds of mechanical and machine tool work pairs and replacements is done, from the ordinary repair work of the blacksmith's shop to the making of delicate instruments, ship carpentry, and cabinet work. Is there any administrative method employed in your city whereby it may be determined what is the labor cost and the material cost of repairs even by classes of expenses to be charged thereby? Do you have any means of determining whether or not it is cheaper to do your repair work in a municipal repair shop or by contract? Of the valuable materials and supplies used in the repair 
shop, do you have any means of ascertaining whether or not these have been used for the purposes of the city? In the repairing of such valuable and expensive instruments as automobiles in municipal shops and garages, do you have any means for finding out what is the cost of keeping your automobile in repair? It is thought worth while to keep records of cost of repairs in private business and records of custodianship for valuable implements and tools; in fact, in private business it is thought to be necessary in order to protect those who are secking to serve the institution with fidelity as well as those who stand in the position of administrative responsibility. May we expect to obtain superior results in a municipality when inferior methods are employed, and when all of the traditions of the institution are based on holding out inducements to fraud, misappropriation, and institutional neglect?

Similar questions may be asked with respect to contracts for construction and other relations of expenditure which make for favoritism, waste, and inefficient service; similar questions may also be raised with respect to municipal revenue. Did it ever occur to you to ask the reason for the existence of the lucrative vocation of tax reduction agencies in our large cities - persons regularly employed who undertake to reduce your taxes for a percentage of

Municipal revthe reduction effected? Has it ever occurred enues

to you to inquire into the methods of handling such subjects of business as water revenues, dock revenues, ferry revenues, park privileges? Do you know what are the methods employed in your city for the handling of security deposits and other trust funds? Do you know whether the trust funds of the city have been impaired or diverted to other uses? Are methods of accounting and reporting employed which 
will regularly bring the answers to these questions to your attention and to the attention of others - which will currently give to you and to others the information necessary to a proper basis for judgment in the exercise of duties of citizenship or of administration? These are the inquiries which are raised by the general subject which is before us, and which are of the greatest importance in the solution of the problem of efficient government in the United States.

The most important event of the year in municipal life is the making of the Budget. This not only calls for report and account by officers, but directly appeals to every taxpayer and to every person residing within the territorial limits of the municipality whose interests are to be made the subject for the next year's expenditures. In the making up of the annual Budget, do you in your city proceed with full knowledge of the facts, or are you working in the dark? As officers do you know what the revenues and expenses of the last year have been, or do you rely entirely on information as to the amounts of moneys received and disbursed without knowing to what extent these have been on account of the business of the The making previous period? Are your estimates based of a municipal on pay-rolls which have been padded to budget make the need seem great? Have purchasing agents laid in a large stock of goods upon orders given to favorites and thus made it to appear that increased appropriations are necessary when by this amount the needs of the subsequent years may be decreased? Have liabilities to tradesmen incurred during the last year been deferred to make the expenses of the present administration seem small, and for the purpose of discrediting successors? Have a large part of the expenses of the year been charged to bond and corporate stock accounts as 
a means of keeping the tax rate down, while expenses are actually increasing? Are you acting on exact information with regard to these facts, or are you doing business by rule of thumb? If you are in the dark, can you expect or even hope to protect the community's interest when others whom we may call "insiders" through personal contact are keeping in close touch with every situation bearing on their own business relation? In the past has not the trouble been the fault of ignorance rather than any innate inability of a municipality to succeed in the conduct of its business?

The greatest problem of government must ever be the municipal problem. As population increases, as business becomes more urban, as the territory occupied by The future of townsmen yields less of subsistence, as inAmerican cities creasing proportions of our people must depend on exchange for foodstuffs and shelter, the functions of government as the organized agency for popular welfare must multiply. From economic necessity, activities which in the past have been left entirely to individuals and companies must be taken over by the municipality. The town-building tendency of the time can have but one meaning - the ever-increasing importance of corporate funding needs and corporate business needs of municipalities. Whatever the theory held as to underlying governing principles, these funding and business necessities, which grow as our cities grow, must force us over to methods of administration by which citizen control, legislative control, executive control, and judicial control may be made effective. This can be done only when these different forms of control are made intelligent. When the American people are in a position to act with intelligence with respect to matters of community interest, then will the municipality in its corpo- 
rate capacity be in a position to undertake any function which the highest welfare of the community may require, and to perform these functions with the same fidelity and the same economy as are found in the most efficient of our great private corporations.

This day is not far distant. There is an ever increasing demand for the introduction and continuance of administrative methods which will provide the information needed to make public administration efficient. It has come to be recognized that the malfeasances, the misfeasances, and the nonfeasances of office in the past have not been due to lack of law. The law at all times has been adequate to bring to justice every person who has proved false to a public office or trust. Failure of justice in every instance has been due to the same cause as inefficient administration, viz.: insufficiency of evidence - in other words, the inability of the courts to get at the facts. The great political campaigns of to-day are campaigns for facts, for publicity, for light, for the keeping and the preservation of records by which the responsibility of every person connected with the government may be proved, for making these records public records; one step further - for bringing a digest of this evidence regularly before every person who is interested and every one who is responsible for the exercise of citizen or official judgment in the management and control of municipal affairs. When this desideratum shall have been reached, then those who are laboring in the interests of the public will be the ones rewarded; then will the faithless and the inefficient be eliminated from the civil service. Not till then may we say that we have given to the municipal employee the same protection and the same encouragement that honest and efficient service is given in private life. 


\section{CHAPTER V}

\section{The Financial Management of Municipalities ${ }^{1}$}

For the purpose of this discussion the word "financial" will be taken to mean - pertaining to funds or to the means of purchase and of payment; "financial management" will be understood to include the means employed for the acquisition of funds, as well as for their administration and disbursement. For the purpose of

Preliminary observations presentation, the English basis of classification will be used as distinguished from the continental, or the prevailing American municipal practice. To be more specific, it will be assumed that, for the purpose of financial management, there are essentially three classes of funds, viz.: Current funds - or those to be used for current purposes of a municipality; capital funds - or those intended for investment or permanent improvement, and trust funds - or those in which the city is interested as trustee or agent for the benefit of another, what is known in law as a cestui que trust. Employing these distinctions throughout, the subject will be reviewed from six different aspects: (I) The method of acquiring funds to be administered; (2) the administration of revenues and expenses; (3) the management of capital funds; (4) the management of trust funds; (5) the administration of cash receipts and cash payments, and (6) methods of financial adminis-

1 Address prepared for the Empire Club, February 16, 1905, Toronto, Canada. Published in Public Policy, April 22, 1905. 
trative control. The nomenclature is that suggested by the secretary of the committee on accounting and statutes of the American National Municipal League for adoption.

THE METHOD OF ACQUIRING FUNDS TO BE ADMINISTERED

In this relation current funds and capital funds only will be considered. The intention is not to discuss the method of acquiring funds, except as this may be incidental to questions of subsequent management; nor can it be hoped that in an address of this kind more than a current mention may be made of some of the leading features of financial administration. To adequately treat such a subject as has been assigned by your secretary would require the preparation of a treatise.

First, then, to engage a few fundamental commonplaces: A city, in the main, must rely on its revenue powers for current funds, i.e., it must depend on its ability to obtain its current means of support from tax levies, excises, fees, fines, profits, or the exercise of other acts of sovereignty, police control, and municipal proprietorship; capital funds, on the other hand, are more frequently acquired by means of municipal borrowing. The reason for this difference in method is at once apparent. The current funds underlying purpose of acquiring what are here called current funds is to repair waste, to prevent depreciation, and to meet the costs of municipal service. Such funds are in the nature of temporary financial supplies - they are to be currently consumed; they are to be used, but in their use no increase in assets is obtained.

Capital funds are for the purchase of properties and equipment; their primary end is to acquire something which may be permanently retained or continuously employed by the city - something in the nature of prop- 
erty and equipment or of an investment which is to be protected, repaired, or replaced at current expense. To restate the distinction, current funds are raised for paying Capital funds expenses, while capital funds are for buying property or equipment which shall not be permitted to become impaired; the one is for municipal subsistence, the other is to increase the municipal estate.

Let us follow this distinction into questions of financial management. As a matter of policy a city could not long rely on municipal borrowing for current funds, since by process of waste and continued cost its borrowing power would soon become exhausted. Borrowing power depends on income; it cannot to any considerable extent, in municipal finance, be based on liquidation or realization on the municipal estate. The only place which borrowing can have as a means of supplying current funds is that of temporary financial relief pending

Limits of borrowing the collection of income accruements, or as a means of supplementing inadequate revenue levies. Such current borrowings must be in the nature of short-time obligations and should never exceed the amount of current income obtainable from revenue sources within the term of the loan. To illustrate: We will assume that the necessary current expenses for salaries and maintenance of equipment were $\$ 10,000,000$ per year. Resort to borrowing to meet this annual cost would only result in postponing the payment of an expense, which, when paid, would leave no increase in the municipal estate. To continue to borrow for such a use would be to cumulate the burdens of taxation which must be met in the future; i.e., to increase taxation without increasing public properties or utilities.

While this is true of current funds, the opposite is true of capital funds. For acquiring capital, municipal 
borrowing is usually better adapted than the making of extraordinary revenue levies. For example: A city hall Advantages of is to be built. To provide the funds necesborrowing cap- sary taxation would require an extraordiital funds

nary levy, which might double the current rate. This would prove oppressive; it might throw the business of the community out of adjustment; it might increase individual expenses of citizens to such an extent as to make business in that community unprofitable.

The financial justification for the building of a city hall is to free the city from annual rent for housing its officers, and for protecting its records and equipment. An immediate capital expenditure of one million dollars might save the corporation sixty thousand dollars per annum in rents. If a million dollars, therefore, were at once raised by process of taxation there would be a resultant decrease in the annual levies of sixty thousand dollars per year. That is, the community would receive six per cent return on its capital investment of a million dollars. But the capital burden is greater than the

Reduction of expenditures

community would care to accept. By issuing a million dollars of four per cent bonds, payable fifty years hence, there will be a margin of two per cent per annum as a saving on the capital cost. Thus, with financial advantage, the principal may be allowed to remain a continuing obligation. Without causing any financial drain on the community by such a management in the borrowing, the community as a whole not only would have gained one million dollars in invested capital, but also would have saved two per cent per annum, or $\$ 20,000$ per year, in current expenses.

We will take another view of the situation. Let us assume that it might be desirable to provide for the ultimate payment of the million-dollar loan. If the building 
were adequately maintained out of current revenues, by setting aside, as a sinking fund, $\$ 20,000$ per annum, or the amount which is saved from revenues, at the end of fifty years the bonds might be paid. The city would have provided itself with a million-dollar capital equipment, and not only have paid the current interest of three Increase of per cent on the loan, but at the end of capital by rev- fifty years would also have repaid the prinenue saving cipal. This would be done at the same annual expense as the city would have been under if it had continued to rent quarters at the rate of fifty thousand dollars per year. But is this the only consideration? Not only would the city have increased its capital equipment a million dollars, but the next generation would be relieved of a current expense in the form of interest and sinking fund equal to the amount of the rent previously paid; assuming that no provision were made for depreciation and the building lasted fifty years, and the city would have the site only, which with the appreciation of land valuation might save the city a large amount in future rents. This illustration is given to raise some of the points of management pertaining to the acquisition of funds for capital use.

Other questions quite as important from the point of view of financial management may be raised with reference to the several classes of capital loans which a city may undertake. Generally speaking, there are four sources from which a city may obtain its capital funds, viz.: (I) From sale of annuities; (2) from sale of corpoDifference in rate stock (or bonds); (3) from appropriamethods of ac- tions of revenue surplus (or extraordinary quiring capital revenue levies); (4) from gifts or bequests of private individuals or corporations. The last method is incidental and entirely beyond the purview of this subject. 
As between the sale of annuities and the issue of corporate stock (or bonds), a number of questions as to advantage may be raised. From the first class of obligations, the question of ultimate payment is eliminated at the time the contract for annuities is entered into.

sale of annu- In consideration of this fact, however, ities and corpo- there must be compensation in the annual rate stock rate. Again, the annual rate may be one in perpetuity, and, therefore, the capital charge is apportioned over future generations.

To bring such a financial plan into comparison with one which provides not only for an annual charge in the form of interest, but also an ultimate payment of principal, and this usually not more than one generation removed, is a matter which requires trained technical judgment. In regard to corporate stock (or bonds) which are unsecured and those which may be secured by a sinking fund or by the pledging of some definite source of income, another series of questions may be raised. To illustrate a point of practice in two of the large American cities: The established policy in the city of Chicago has been, not only to provide a sinking fund at the time that the loan is made, but also to make the tax levy and an appropriation by the same ordinance that authorizes the loan. The result is this: The municipal indebtedness of the city of Chicago is at all times secured; the capital appropriation for sinking fund is

Secured and unsecured loans made a prior lien on the annual assessment, coming ahead of revenue appropriations for current expenses; furthermore, the bonded debt is constantly in the process of liquidation out of appropriated revenue surplus. If, therefore, we compare the bonded debt of the city of Chicago with that of New York, we will find that, while in 
population the proportion is about as one is to two, the bonded debt is about as one to twenty. That is to say, the per capita indebtedness of the city of New York is many times greater than that of Chicago. Assuming the total capital assets of the city of Chicago to be one hundred and fifty millions, and the total capital assets of the city of New York to be three hundred millions, and assuming financial relations to exist as above described, by reason of the sinking fund requirements of the city of Chicago and the method employed for meeting them, the capital liabilities would be fifteen million dollars in the form of loans, and one hundred and thirtyfive millions would appear as invested revenue surplus. On the other hand, the full $\$ 300,000,000$ of capital assets of the city of New York would have been procured by means of loans with little or no invested revenue surplus. The exact comparative statistics are not at present available, but the difference exists and the amounts taken serve to illustrate a difference in funding methods employed in the two cities.

\section{THE ADMINISTRATION OF REVENUES AND EXPENSES}

Income and expenditures are those transactions which in English cities are included under "revenue accounts," as distinguished from "cash receipts" and "cash disbursements." For the same ideas the National Municipal

Definitions and use of terms

League has used the terms "revenues and expenses" instead of "income and expenditures," while the United States census, in dealing with the financial statistics of municipalities, employs the words "rerenues and expenditures." These, however, are but different terms for the same financial concepts, the purpose being in the "income or revenue" accounts to make a complete record and financial sum- 
mary of all accruements to the municipality from tax levies, fines, fees, licenses, etc., during a given period under review, and to oppose to this total the amount of all "expenses" or costs of administration incurred during a like period.

The purpose of such a record and such a summary is that those in administrative control may know whether the city is providing for itself adequate means of support or is cumulating for the future liabilities for the cost of current operations and maintenance. The management Administrative of the "revenues and expenses" of the purposes of rev- city must have reference to three adminenue accounts istrative problems: (I) A question of surplus or deficit in current funds to meet the running expenses of the city; (2) the availability of the "income" at the time that it may be needed, and (3) the question of economy in every branch of the municipal service for which funds are provided.

It is a trite saying that a city is not in business for profit. Nevertheless, it must provide itself with adequate revenue. The first problem of financial management is to protect the corporation against a deficit. It is to this end that the device known as a "budget" is instituted. But the budget may not be intelligently Determination constructed without a system of accounting of surplus and by which the "revenues and expenses" of deficit

the city may be as accurately determined as are the earnings and expenses of a railroad or of a manufacturing plant. The budget, when prepared from the municipal cash book - or the records of receipts and payments - is a financial chart prepared with only one of the two points established from which a safe administrative course may be steered. From this may be known whether the receipts of years past have been 
adequate to meet current obligations, but whether these receipts are drawn from current income sources, or from loans, whether the receipts were derived from current assets accruing during the fiscal year, or an account of a previous period, whether there was a deficit or a surplus of income as compared with current expenses, there can be little more than a guess. It goes without saying that such a method is not a safe one in the financial management of a municipality. Such a method does not lay the foundation for exact administrative judgment. If employed in private business of large undertaking, nothing but fortuitous circumstance would stand in the way of financial ruin. From such data neither the public officer nor the citizen is able to estimate the ability or intelligence of those entrusted with the direction of municipal affairs.

This suggests another consideration in the management of municipal income. Not only must the current revenue provisions be adequate, but the current revenues must be collectible and made available in the form of "cash" at the time that "cash" is needed to meet current obligations. The government is brought face to face with such questions as the following: (I) What method may be used the most effectively to reduce tax levies and other forms of revenues to "cash" when needed? (2) Assuming that such a method may be emMethods of ployed, will it be more expedient to have making rev- resort to financial provisions which will enues available insure prompt collection, or, with greater leniency to the taxpayer, to provide the city with current funds by borrowing? (3) If borrowing is resorted to, is the unsecured "temporary loan" or the secured "revenue bond" the more advantageous financially? (4) May it not be well for the city to shift the financial burden 
completely through local assessments and representative dealing?

To illustrate some of these methods: (I) A tax is levied under a law which offers a discount for payment before the tax becomes due; a constantly increasing penalty is placed on delinquency; supplemental to this, as in a Devices for number of American cities, a provision of prompt collec- law is invoked that no property transfers tion will be valid until the tax is paid. By application of such methods promptness in revenue payments is not only encouraged, but in a large measure insured. The city may reasonably expect to be able to live on its current income, provided the levy is sufficient. And these measures would be considered nothing more than reasonable diligence in private business. Yet they are seldom applied to municipal affairs. The thought seems to be that the municipality, at all times, should wait on the private and personal convenience of its citizens. Nevertheless complaint from citizens is sometimes heard that the affairs of the city are not conducted in a businesslike manner. (2) Not wishing to resort to such severity, the law may be made less strenuous and less exacting to the taxpayer. After it has taken the necessary steps to provide itself with adequate current revenue,

Delayed collections and temporary loans instead of collecting that which is due, it may decide to issue its current credit obligations to an amount of ninety per cent of the tax unpaid. This is a close approximation to the system now in rogue in the city of New York. (3) Or the city may be allowed to hypothecate the tax levy and borrow seventy-five per cent against it in "anticipatory tax warrants." That is, the city may avail itself of the levy before it is due for the purpose of hypothecation, as in the city of Chicago, with- 
out incurring any deficiency liability whatever for failure Hypothecation to collect. The second expedient above set of revenues and anticipa- rent obligations, when its revenue collections tion of tax warrants were nearly a year behind; the third expedient referred to would allow the city to meet all claims against it and run a year and a half behind in its revenue collections. While these methods may appeal to a self-centred taxpayer (and there may be an immediate gain to the individual on account of evasions), it can readily be seen that such methods do not permit those responsible for the management of the financial affairs of the city to exercise the best judgment or to render to the community the highest service. Neither may it be said that in the end it is a saving to the citizen; the method is one of postponement and final loss, rather than of economy or of reduction of corporate liabilities. (4) As a means of avoiding the current necessities for revenues and for the enforcement of revenue Local assess- payments to the city, it may be permitted ments in lieu of in such matters as street sprinkling, street revenues cleaning, street repairs, street lighting, sewer construction repairs, etc., to make local assessments. For such improvements as those the city may act as agent of the property owners, and these who take contracts for performing services of the kind would have a claim, not against the city, but against the individuals whose property may have been affected thereby. The contractor is permitted to recover by direct action against the property owner, as for debt; his security is a statutory lien given on the abutting property benefited.

Aside from questions of deficit and availability, another class of revenue problems inheres in the method of applying revenue receipts to the satisfaction of current demands, 
As a primary restrictive and protective device it is common among Anglo-Saxon people for a council, the representatives of taxpayers, to hold the public purse strings. To prevent extravagance each office and department may be restricted to appropriations, and to protect the treasury against collusion, these appropriations are in many instances made specific and not transferable. An appropriation is an authority to spend. Without this authority the office has no right either to incur expense

Application of revenue receipts

or to authorize payments by the treasurer. To make these appropriations specific and not transferable is one way to manage the application of funds to municipal use; another is to make appropriations general, leaving to the heads of the several departments a large measure of discretion. Again, appropriations general or specific may be made continuous or they may revert to the general treasury at the end of the fiscal period. The former device gives a certain amount of administrative independence, while the latter leaves the officer and department helpless until new appropriations are made by the council. Both as a matter of accounting and as a matter of financial administration and control, the English parliamentary method has much to commend it.

Financial management in its most important relation has to do with municipal economy in administration. For this the English system of revenue accounting is a Financial econ- necessary foundation. Not only must the omy in admin- officer and the citizen know that the govistration

ernment is living within its means - that it is not incurring a deficit - but it should also be known whether the people are receiving the largest amount of public service possible at a given revenue cost. It is by the latter standard that efficiency in government is to be 
judged. For judgment as to municipal economy the American cities are almost completely lacking in the necessary data. English cities also have much to do before the best management may be attained. Judging from published reports, one of the most complete and consistent systems of revenue accounts in England and Scotland is that of the county borough of Bolton. In the treasurer's report there is a complete exhibit of "revenue accounts," as well as of "capital accounts" for each department and municipal fund; but his report lacks a statement of "cash receipts" and "cash disbursements," one of the essential

\section{English}

methods elements for budget estimates. It also lacks a comparison of expenses incurred with municipal service rendered; from such a comparison must proceed all judgments as to administrative efficiency and economy. The significance of this report is this: that while the county borough of Bolton may have an accounting system which lends itself to every administrative need, there is nothing in the financial report to show that the management has made the highest use of that system. The same may be said of the report made for the city of Chicago, where a complete revenue system has been introduced.

Other English and Scotch cities have introduced a revenue system of accounting. Many of them have not, however, a complete accounting basis for the determination of questions of economy. Among the hundreds of American cities, not more than half a score make any attempt to get at a true basis for exact judgment as to relations of economy or cost to service The American rendered. In the few that are rising to
situation

the situation, however, they have adopted the best accounting standards, and it remains only for the application of accounting results to statistics of service, 
and for the reporting of these results, to serve as a guide to the officer and for the information of the public. The American cities within a few decades have risen from small beginnings to their present proportions. To-day we have sixty-two cities as large as New York was one hundred years ago. In truth the United States in common with the rest of the civilized world is coming to be a "nation of cities." It has been only within the last twenty-five years that the municipal problem has become a serious one. Within the last ten years there has been an awakening on questions of municipal reform looking toward efficiency in administration. Enlightened citizcnship has turned to the best models in England and continental Europe. The progress made in law, and accomplished reform, marks but in small measure the movement which has been going on.

For five years the National Municipal Lcague has had a large committee at work formulating opinions which might serve as a basis for legislation for the direction of Agencies of citizen movements, and for the crystallizapublic munici- tion of political thought. The bureau of pal education the census at Washington, adopting the general classification of cxpenditures formulated by the league committee, is at present employing an investigating force, and is doing much to unify and direct local methods and opinion, and to harmonize these with the best thought of the time. A League of American municipalitics has been organized and promises to give attention to the subject. Various technical and learned societies are applying themselves to the task. The best intelligence of all these is being coördinated through correspondence and conference. Citizen and patriotic socicties, such as municipal roters' leagues, legislative leagues, reform clubs, ctc., are cducating public thought 
and organizing forces to accomplish legislative results. The last decade has been one of educating public opinion; in the next decade we may hope to see definite results in administrative plans and in constructive law based on the highest ideals of municipal finance and management. In these efforts to obtain an intelligent basis for municipal organization, and for official and citizen judgment with respect to financial administration and control, questions of economy have played the most important part.

\section{THE ADMINISTRATION OF CAPITAL AND LOAN FUNDS}

The best device in present use for the management of "capital and loan" funds is the English capital balance

The capital balance sheet

sheet, by which there is a complete segregation in the summary made of capital and loan accounts. This, however, is not at all times followed by British cities in making their financial statements. To refer again to the county borough of Bolton, which has published such an excellent report of revenue accounts, the capital and loan items are not separately set forth. There is a complete asset and liability accounting, but in this the current accounts appear in the same summary as the capital accounts. In none of the published statements do we have the best administrative standards consistently followed by British cities. As a result, it is fair to assume that the best administrative ideals do not there prevail for the purposes of financial management.

Distinguishing the ultimate capital purpose as being one for permanent or long continuing use, the funds intended for the acquisition of properties, for investments, and for equipment, whether derived from bond sales, from revenue appropriations (as sinking funds), or from 
gifts and bequests, should be so completely segregated "Capitalfunds" and set forth that there could be no to be segre- confusion of thought with reference to gated these. There should not be a commingling of capital assets, for the reason that the officer and the citizen should, at all times, have before them the capital "funds," as distinct from "properties and equipment." And "capital funds" should not be confused with "current funds" or "trust funds," not only for the reason that such confusion in accounts and in public thought is the most frequent cause for misappropriation and official default, but such an accounting tends to distort official vision and thwart intelligent judgment.

All capital should be protected, and to this end completely segregated from current items. Municipal capital should not be used or reported as a basis for credit, neither should statements as to capital funds and capital equipment be esteemed as information published for the benefit

Capital assets to be protected

of bondholders and other public creditors.

Rather such accounts and such summaries should be set up for administrative reasons. The purpose of "current assets" is the liquidation of obligations. "Current cash" is for immediate application to obligations; other "current assets" are for conversion into "cash" for similar use. It is the income of the city and the amount of "current cash" and "current assets" on hand which determines the credit possibilities of a municipal corporation.

"Capital assets" are not for realization; they are for Capital assets continued and permanent use. It is connot for realiza- tended, therefore, that those English forms of tion

balance sheets which classify capital assets as (I) "Assets remunerative and realizable"; (2) "Assets unremunerative and realizable"; (3) "Assets unremun- 
erative and unrealizable," or any similar classification which has in mind realization, for administrative and financial purposes, is meaningless and confusing. Such classification does violence to the underlying principle and purpose of the capital balance sheet. A classified exhibit of capital assets is a statement designed not to show the possibilities of realizing of cash, but is intended rather to serve as a basis for property administration.

This distinction is as true of a railroad or of an industrial enterprise as it is of a city. A railroad cannot and does not intend to realize on its right of way as a distinct class of assets. It cannot realize on any part of its property that is intended and needed for permanent equipment without impairing its earning power, and, therefore, defeating the very end of realization. The only manner Classification in which an enterprise can realize on capital for administra- assets is, partially or wholly, to wind up tive purposes its affairs. When a particular property may be realized on, this fact should be reflected in the accounts by being at once taken out of statements of capital assets and set up as a current asset. As before suggested, the primary purpose of capital accounts in private business, as well as public, is to serve as a guide to officers in getting at such questions of management as renewals, depreciation, distribution of surplus, etc. These are all purely administrative problems, and the valuation of capital assets proceeds from an administrative point of view. The valuation represented on the capital balance sheet is not based on realization or salability, but rather on reproduction or capital cost.

Every judgment pertaining to the capital accounts, whether for purposes of financial and statistical representation or for purposes of management, has to do with a different class of judgments than those surrounding the 
current assets of the corporation. This is true in private Basis for judg- business. It is, if possible, even more true ment as to cap- in a municipality which has not the remotest ital assets idea of selling any part of its property or equipment represented in its capital accounts, and as soon as such an institution makes known its intention to dispose of any part of its property or permanent investments, just so soon must this part of its property or investment be taken out of the category of capital assets and revalued from the point of view of salability or cash realization.

A proper regard for the financial management of capital funds and for the administration of properties and equipIdea of pro- ment of a municipality should have in mind tection funda- their protection. Funds must be safely mental

kept and invested to protect them against loss of principal. The properties must be protected against wear, waste, and depreciation. Equipment must be replaced and the proper capital funds set aside out of current revenues for such replacement. An accounting which will lay the foundation for correct judgment must have respect to such problems as these - must have regard to this underlying distinction to lay a proper basis for financial management.

\section{ADMINISTRATION OF TRUST FUNDS}

The reasons above urged for a separate accounting and for a complete segregation of capital funds and properties from current assets will apply with equal force to Segregation of trust funds and estates. Added significance Segregation of
trust funds relations established. Not only does civic pride and the reputation of the community for fair dealing require that trust funds and trust relations be pro- 
tected, but also a proper regard for the rights of parties in contemplation of law. Another reason, purely administrative, is urged. There is no surer way of inducing dishonesty, corruption, and loose financial practice than to confuse trust moneys with municipal corporate funds. Not only should there be a strict asset and liability accounting for trust estates, but also such a record of income and expenditure as will insure economy in management. For better intelligence with respect to this department of $\mathrm{mu}$ nicipal service a distinction should also be made between private trusts and deposits, public trusts, revenue agency funds, and local improvement funds.

\section{MANAGEMENT OF RECEIPTS AND DISBURSEMENTS}

The more frequent fault in public accounts is to confine the record and reports to a detailed statement of "receipts and payments," while the accounts of "revenue and expenses" are neglected; in other words, cash accounts alone are kept. Quite as fallacious is the keeping a strict account of "revenues" and neglecting the cash transactions of the public treasury. The revenue accounts are necessary to economy of management. The cash accounts are necessary to the protection of official fidelity. A correlation of the two must be made as a basis for the budget. Receipts and payments have to do with the

Cash to be accounted by funds flow of cash - they pertain directly to the treasury. These must be strictly kept with reference to legal and administrative funds. Not only is official fidelity dependent on a strict account of the flow of cash, but also for administrative purposes, both as a guide to effort toward collection and as a basis for temporary loans, exact knowledge as to the balance in each fund is imperative. 


\section{METHODS OF FINANCIAL CONTROL}

Effective control is essential to efficient financial management. Under a system of popular government, such as is common in Anglo-Saxon countries, there are five distinct controlling relations to be noted: (I) Revenue control is secured through a representative house or council, Organization in which all revenue measures must originate for financial and whose action and approval is necessary control

to appropriation. (2) Administrative discretionary control is attained through the executive and through the various administrative discretionary heads subject to whose motion or discretion appropriations are disbursed. (3) Accounting control has more recently been added by the institution of a department or office, at the head of which is a comptroller, and in aid of which is devised a system of financial accounts. (4) Judicial control is found in an independently organized system of courts which may at all times be appealed to to enforce the performance of official duty and to protect municipal corporate rights. (5) Popular control - over council, executive and financial officers - is secured through elections and appointments.

For purposes of revenue control there are various forms of council organization and various boards of appraisement, apportionment, appropriation, etc., for the advice of members of the council, subject to whose initiation and final adoption revenue measures are passed and an appropriation made. These various devices canRevenue con- not be gone into at this time. Generally
trol speaking, there may be said to be two classes of orders. The first to be noted is one in which there is no coördination - each department or office representing its wants and pressing them before the council, their 
requests to be granted or not granted, cut, sliced, and finally passed without regard for administrative results, for political or other reasons. The other is a system by which all estimates and financial demands of officers and departments are submitted to a board or committee, which may properly consider the wants and administrative needs of every division of government, and having in mind the tax limitations or financial condition of the community, may trim and adjust them to a consistent plan and to such a revenue basis as may come within the taxpayer's means without jeopardizing the government or impairing its efficiency.

In administrative discretionary control lies the whole problem of directive intelligence and municipal economy. As to this there has been a wide divergence between the English and Scotch development and the newer American Administrative adaptation. In England and Scotland, for discretionary centuries, a contest was waged between the control representatives of the people in council and the representatives of the crown or executive head. The result has been that gradually administrative functions have been taken away from those in executive position and absorbed by committee of the council. Local conditions and those customs which have grown up around concepts of local official dignity have made the English and Scotch mayor a chief social functionary, while the principal business and the administrative functions of the municipality have been placed in the hands or heads of legislative committees. Through such organization mature discretion has been assured.

The newer American models have had in mind administrative effectiveness rather than deliberation as a basis for control. Under conditions which have in the main been without contention as between mayor and 
council - which have been utterly devoid of a sense of "dignity" to be supported by the chief exccutive - without those customs and social precedents which require English and an official personage to represent the comAmerican munity "socially" - there has been no models peculiar line of social demarkation between one class of officials and another which would require the mayor to devote himself to receptions and other courtly functions, leaving to the council (the representatives of the people) the less dignified and ungenteel "business" of a corporation. Our models for administrative efficiency and control in municipal government are found rather in the large private corporation, for which America has recently gained world fame. In an American railroad corporation, for example, the operative head is its president. The board of directors (the council) controls in all financial matters and determines corporate policy. This is the working ideal of the American corporation.

In private corporate organizations, the greatest economy and the highest working efficiency is obtained, not by portioning out official direction and administrative control to a number of committees responsible to a deliberate body, but by giving a single directing head the power to command and control the many corps of employees cooperating for common ends, and by holding this directing head - this person in command - responsible for the Centralization operative result. That he may be able to vs. decentraliza- exercise intelligent judgment in administertion ing the business of the corporation, an efficient accounting service is installed, one by means of which he may have a complete record and summary of financial results.

He is likewise given a department or burcau of inspection as a means of obtaining exact information with respect 
to the physical and operative results. Current periodical reports are required from each branch of the service, that he may have before him departmental results. A department or bureau of statistics and research is kept at work coördinating all of the various reports (financial, physical, operative, and departmental) around the problems concerning which exact knowledge is required for the exercise of mature official discretion, to enable him to have the best discipline in the service, on which he must depend for the execution of policies instituted. And for the administration of operative plans he is given liberal powers of appointment, suspension, and removal of departmental heads. Likewise, for similar purposes, the several heads of departments are given control over deputies, assistants, and employees serving under them.

With these several means of information at his hand, with these commanding powers of bringing the personnel of corporate employment into organic corporate service, the administration of the working Methods of con- group in a modern American corporation trol under a is very like the direction to the several centralized civic or industrial corps of an imperial system army. This ideal has not been entirely worked out in American municipalities, but it is the model toward which certain of our American municipal organizations have been moving - a model for administrative efficiency and for effective direction and executive control which, in turn, must find its safety in (I) the financial control which is exercised by an intelligent board of directors, the council, (2) in an independent accounting service under an independent and intelligent controller, (3) in the independent judicial administration of the courts, premised on their ability at all times to obtain full evidence of all transactions and full information necessary to the 
enforcement of official responsibility, and (4) in a wellinformed electorate exercising popular control through the election of a chief executive and the consequent possible reorganization of the departmental discretionary official staff.

When these conditions are not present, when the information for the exercise of intelligent financial control is not regularly and currently available, when an adequate

Conditions under which decentralization is preferable accounting service is not provided, when the judiciary may not be effectively invoked for the protection of the public trust and evidence is lacking by which judicial control may be effective, when the facilities are not present for keeping the electorate informed, the more effective method of government may be one of decentralization - i.e., one of dividing up the functions and responsibilities on some council or commission plan. In this manner the lack of records, the lack of needed evidence to fix responsibility, the lack of reports may be supplied in the same manner as in a small private business, viz., by personal contact. 


\section{CHAPTER VI}

\section{Principles of Budget Making ${ }^{1}$}

THE budget is an instrument devised to give to the direct representatives of the people control over administrative officers. Finding its origin in monarchical government, it has, where not neglected, become one of the

Constituent

elements in municipal governments most effective limitations of administrative authority. According to democratic ideals that form of corporation known as "the Government" is made up of three classes of persons: (I) a body of electors; (2) a council or board of representatives, and (3) a group of administrative officers and corporate employees. The corporation thus composed is responsible to what is known as "the State" - i.e., to the politically organized body of citizens for whose protection and welfare the government has been created. Each of these three classes of corporate agents have duties to perform and may be penalized for not performing them. In the interest of citizen welfare each is given a distinct form of governing control: To the elector is given popular or electoral control; to the council of representatives is given general directive or representative control; to the administrative officer is given administrative control.

1 Journal of Accountancy, October, 1907. 


\section{THE BUDGET AS AN INSTRUMENT OF CONTROL}

Corresponding to each of these several functions, each has developed appropriate instruments through which control may be exercised and made effective. Control

Primary methods of control

by electors is effected through petition and ballot, by which means electoral initiative, selection, and sanction are expressed in constitutional and charter grants, in the choice of representatives and elective officers, and in instituting, approving, or annulling the acts of representatives and elective officers. To the representative body or council the instruments of control available are statute, ordinance, and budget - the first and second being instruments of legal control, the budget being an instrument of financial control. To the officer, to whom is given the duty of corporate management and of administering the details of business, the most effective means of control over the many employees for whose acts he is held responsible and over the funds and properties in their keeping, is his power to appoint, suspend, and remove, and his power to induct methods by means of which the organization under him may be made effective.

CONDITIONS PRECEDENT TO THE EFFECTIVE EXERCISE OF CONTROL

Each of these three controlling groups of corporate agents must act on information if it acts wisely and efficiently. In towns or other governing bodies whose territorial limits are too wide for personal surElectoral control vey, whose population is too numerous or too diverse to retain neighborly contact, whose activities are too complex for the citizen to observe, intelligent action on the part of the elector must proceed 
from exact knowledge presented in the form of reports. Are constitutions or charters to be voted on? To act wisely the elector should have a full and accurate statement, not only as to the manner in which the old constitution or charter has operated, but also a well-considered brief as to the manner in which the proposed measures, if adopted, may operate. Are candidates presenting themselves for election or re-election? Electoral control can be intelligently exercised only after a full and accurate report on the manner in which those who have held positions of trust have conducted the affairs of the corporation. Are measures to be introduced by competitive or popular initiative? Are acts of representatives referred for popular sanction? Are the electors appealed to to recall those who have been appointed to positions of responsibility? Whatever the action to be taken, an electorate which is uninformed, instead of conserving public welfare, may, by appeal to prejudice or by demagoguery, defeat the very purpose for which electoral control is established.

The same is true of acts of the representative body. Effective control must proceed from such knowledge of Representative affairs that intelligent judgment may be control

exercised. Is the subject for consideration

a change in statute or ordinance, or the passing of the budget? Action taken which does not proceed from full and accurate information must of necessity be abortive.

The officer on whom rests responsibility for administrative control is under the same necessity. Each official official control act, each command to subordinates, each business transaction coming before the officer for his direction or approval, should be premised on an intimate and exact knowledge of all the details entering 
into the problem. Without such information the officer is a helpless incompetent who may at any time be made the victim of political scandal. Without the protection afforded by full knowledge of facts prior to a decision made or a responsibility executed, reputation for honesty and efficiency is at all times in jeopardy. Even when animated by the best of intentions, an officer who acts in ignorance may be made the tool of a coterie of persons seeking to subvert the powers and properties of government to private ends.

Efficiency, economy, and fidelity - these have come to be the criteria of official acts. The development of such qualities in a government is not so much a matter of men and measures as it is a matter of method; not so much men, as methods by means of which full and accurate information may be given to those upon whom fall the duties of exercising control. Given the methods by means of which the full situation may be known and by means of which responsibility for every act may be located, and efficient men and measures will necessarily follow.

METHODS OF OBTAINING INFORMATION AS A BASIS FOR EXERCISE OF CONTROL

The needed information must of necessity come from those who are in direct contact with the business of the corporation. The method has to do with the recording, classifying, and reporting of this information, as well as with the means of directing affairs after such information has been recorded, classified, and reported. The method itself, therefore, must be administrative. It must relate Information as to the collection and preservation of the a basis for con- evidence of efficiency, economy, and fidelity trol

and to the locating of responsibility for inefficiency, waste, and infidelity. New charters and new 
laws cannot produce effective public service. Any instrument effectively and intelligently used is preferable to a much more perfect device in the hands of the uninformed. When governments have been subverted to private uses, this subversion has not been due to essential defects in the law; fundamental laws, which establish the several forms of control enumerated, together with the broad legal and equitable principles of ultra vires and of trusteeship, are sufficient to protect citizens against every form of inefficiency and corruption. To reach this result, special laws and specific rules and regulations are not necessary. Where political and administrative action has proceeded from intelligence, there has been little cause for complaint; where charges of infidelity have been supported by evidence, there has been no cause for pessimism. Failure in municipal government has come from lack of evidence and not from inadequacy in law.

Nor are we lacking in the experience as to administrative methods which will enable the officer, the council, or the elector to obtain full and complete information on every subject and transaction concerning which information is needed for purposes of intelligent control. These The experience methods have already been established in of private business

the management of private corporations. They have also been applied to different aspects of public business. It remains only for electors to demand and insist on the introduction of these established methods of administrative accounting - to demand and insist on the introduction of scientific methods of obtaining accurate operative data - to demand and insist on the introduction of adequate methods of recording the evidence by means of which responsibility may be located for each order or advice given in the direction of the affairs of a municipality. In a word, it remains only 
for electors to shift the emphasis from men and measures to methods of administration and to demands for a full and accurate knowledge of results to avail themselves of the benefits to be derived from both.

In the past the safeguards imposed on government have been negative. Systems of check and balance and civil service regulations have been negative. We need something positive - methods which will put a premium on ability and honor. When a method shall be installed Safeguards of which will make and preserve the evidence the past nega- of personal credit or discredit to be attached tive

to the acts of each official and municipal employee, then and not till then will municipal administration lose its taint and men and measures be chosen with the same assurance that now obtains in industrial and commercial lines. Without methods which will locate responsibility for inefficiency and the wasteful use of public revenues, a premium is set on the abuse of power and privilege and honorable citizenship is itself ineffective as against persons who, though publicly condemned, are publicly subsidized to combine their resources in obtaining personal gain from the subversion of institutions of public welfare.

\section{CONTROLIING PURPOSES OF THE BUDGET}

The immediate purposes of the budget are two: (I) to enable a representative body, charged with the making of proper provisions for raising revenues and the protection of funds, to exercise control over the officers charged with Significance of the details of administration by placing limitation of limitations on their authority to spend; authority to (2) by establishing such limitations of spend authority, thus to enable the controlling financial officer (in most cities known as the comptroller) 
to make use of the law of ultra vires, in determining whether claims presented constitute legal obligations which should be approved by him for payment. The act of the representative body. by which the budget is passed and by which authority to spend is given, is called an act of "appropriation" - an act setting aside or reserving such amounts or funds of the corporation as may be therein determined and set forth. In most municipalities a council or board of aldermen is the appropriating body; in some of the larger cities, the budget originates with a specially constituted board or commission which is charged with the determination of facts, from which board or commission a definitely formulated document comes to the council for final approval or adoption. In New York, for example, this specially constituted board or commission is known as the Board of Estimate and Apportionment, composed of the mayor, the comptroller, the president of the board of aldermen, and the five borough presidents. This board or commission (each member being elective) receives estimates from the several departments or divisions of city government, as well as from private institutions asking for municipal support, and fixes the classification and maximum limit of appropriations; with the budget thus formulated it goes before the Board of Aldermen for final adoption - the Board of Aldermen having power to reduce but not to increase the amount of any item contained therein; thereafter it goes to the mayor for his approval or veto.

As commonly used, the budget operates as an instru-

Use of budget as instrument of positive control

this much," and to that administrative officer, "You 
may have that much," to spend during a definite fiscal period. Any board or representative body may listen to the importunities of politicians or may make a horizontal reduction to bring the total of all estimates within a given tax-rate. Negative control may protect the taxrate, but it does not give direction to an intelligent representative control over public service nor reward competence and honorable dealing. On the contrary, it encourages inefficiency and dishonesty. It puts the upright official into competition with the ward politician and success is made dependent on party organization and on false representation of facts in the padding of estimates as a means of obtaining a disproportionate share of revenues to be expended as party spoil.

The use of the budget as an instrument of positive control requires mature deliberation, based on full information. The budget-making body is a council of representatives and as such it is in a position to give direction to the whole corporate policy of a municipality. The support to be given to every function and activity of government is within its keeping. Not only is it within its authority to establish a policy and to publish to each department the amount of support to be granted at the beginning of each fiscal period, but also by revisory acts and transfers to change this policy and to add to or withdraw support at any time that it may deem such action necessary to the improvement of the public service or expedient for the protection of popular welfare.

Looking upon the budget as an instrument of positive control in the hands of a representative body or board, Administrative a first essential to this effective use is a sysaccounts as means to end tem of accounts and operative statistics by means of which an intelligent conclusion may be reached as to the public service rendered and as 
to the cost of such service in each of the several departments, divisions, and institutions asking for public support. In a municipality numbering its activities by hundreds, its employees by thousands, and its expenditures by millions, the intelligent making of the budget is at best a difficult process. Not only is the work of each department and division on the service to be considered, but each function and activity within each of these departments and divisions should be carefully scrutinized in the light of public necessity. If the budget-making body is to exercise financial control intelligently and effectively, it must consider (I) whether each function or activity which has been supported should receive further support; (2) the relative public importance of each function and activity to the general administrative scheme; (3) what amount of financial support is necessary to maintain this relative importance, from the point of view of the public and its interest. And no process should be considered as too laborious to make each of these considerations effective.

\section{MAKING OF THE BUDGET}

By reason of the peculiar position of the board, the third subject of inquest above suggested necessarily comes first. The information as to the amount of support needed is first sought from the department head. Initially, this inquisition takes the form of a request for estimates. A common form of request is that each estimate shall be accompanied by a statement as to the cost of maintaining the department during the last closed fiscal period with the proposed increases and decreases thereon indicated. This information, however, is usually deThe preparation of estimates

fective in the following particulars: First, the expenditures on behalf of the department may be shown without clearly defining whether these 
expenditures pertained to the fiscal period under consideration. Second, if the cost of the fiscal period has been carefully distinguished, this cost may not be set out in such detail as to make it intelligible. Third, if set out in detail, it may not be classified in such manner as to show the cost and the items of cost relating to each of the functions and activities maintained. Fourth, if the cost is set out in detail by function and activity, the statement may not be accompanied by a report showing the public services performed, such services being properly related to the cost of performing them. Fifth, the department may not be asked, or, if asked, may not show in what direction its functions and activities may be or should be developed to further promote the public welfare. Sixth, if such statement of proposed development be made, the opinions of the heads of the departments as to the relative importance of public service at present performed and of the suggested new or enlarged activities may not be made available to the board.

But even with a full report from the head of each department on all of the subjects above indicated before the board, it is not qualified to pass the budget. Representations by department heads are not the best evidence either as to whether all the present activities should be supported, $\begin{array}{ll}\text { Collateral in- } & \text { what amount of support should be given } \\ \text { quiry } & \text { to each, or as to the relative importance of } \\ \text { the work of the department as a whole to }\end{array}$ the general administrative scheme. The estimates and reports by department heads, therefore, should be received long enough in advance to enable the budgetmaking body to conduct an independent and collateral inquiry. For this purpose not only are departmental accounts and service records from which every essential administrative fact may be determined a prime 
necessity, but also an independent or essential service through which the board may direct the investigation an agency which may stand in advisory relation to the board through briefs carefully prepared both as to facts of past administration and as to prospective needs.

But such measures and such service do not exhaust the possibilities of inquiry. Independent advice, thus Publication of obtained, does not put the board in a poestimates of and sition to become intelligent inquisitors. examination of Preliminary estimates and statements of heads departmental needs should be made public in order that the people, in the press and in citizens' organizations, may discuss each of the issues presented. Heads of departments may be cited to appear and answer interrogatories. Citizen bodies may be heard in support of the enlarging or discontinuing of different branches of the public service in which they may be interested.

After full hearings as to relative needs, the board may with much intelligence fix the gross amounts to be appropriated, including all expenditures for the succeeding year, and show separately amounts for current expenses, amounts for the paying of deficiencies in past Formulation of appropriations which have been permitted tentative budget to accumulate in the form of claims or which and taxpayers' hearing amounts provided for the sinking of the funded indebtedness. Gross budget allowances being tentatively determined, the public can be taken into the confidence of the board by having these tentative schedules published, with a day appointed for a hearing in order that taxpayers may appear and oppose or support the tax-rate necessary to providing the revenue needed to make the budget effective. By some such proceeding the budget-making body may have the benefit 
of the expression of public opinion at every important step on subjects which would require increase or decrease in expenditures.

A conclusion being reached, subject to review as to the tax-rate, further important information may be elicited by notifying the heads of each department as to its apportionment, and asking them for written Supplementary advice on forms submitted as to how the
inquiry department would have this amount distributed among the several functions and activities to be maintained. This apportionment and the several advices being published and time being given to consider, another public session may be had, after which the budget may be definitely placed. Whatever procedure be followed, the board should seek to avail itself of every source of information both as to the past cost and as to the future need of each function and activity to be maintained, and so informing itself become a positive force in the general direction and control of departments and administrative officers.

\section{THE ADMINISTRATIVE IMPORTANCE OF THE BUDGET}

In this relation, something may be said of the administrative importance of the budget and of the conditions necessary to its effective use. The budget is in the nature of an allowance. As to whether proper use is made of this allowance depends on administrative intelligence and control. Efficiency, economy, and fidelity are administrative facts. The positive purpose of the budget is to As related to give direction to, and place limitations on, methods of administration. Administratively, there are control two general methods of control which relate themselves to the budget: (I) control by the audit and vouching of claims against appropriations, for which 
the city comptroller is responsible; and (2) control by the executive who seeks his information as to administrative facts in current reports and who enforces executive judgment through his power of appointment, suspension, and removal of departmental heads.

The administrative relation of the chief executive to the budget has in large measure been overlooked. Definite allowance having been made for the support of certain public functions and activities, the mayor may exercise a most wholesome influence in general supervision over the use of these functions. For example, an appropriation may be made to the board of health for salaries and wages under the general title of milk inspection. Presuming that the board of health may desire to use this money for political purposes on the approach of an election, it may decide to expend the whole amount within three months. The effect of such a decision would be to defeat the purpose of the appropriation. Generally speaking, the public service is to be a continuous one. In the audit Executive supervision may therefore be and vouching exercised to prevent a disproportionate exof claims

penditure at one time and a consequent crippling of the service or making necessary supplementary appropriations at another. In every such case where disproportional expenditures are allowed there should be clear administrative reasons for doing so, and these should be brought to the attention and discussed with the chief executive. This form of administrative control must be enforced through prompt and frequent reports rendered by the several departments to the mayor, to the making of which a thorough and centrally controlled system of administrative accounts is a prerequisite. Through the medium of reports regularly rendered, through inspection and the inquisitorial powers within his reach, 
the chief executive may also prevent the forcing the hands of the council by over spending in the management of certain necessary functions, thus requiring that provision be made for their maintenance by transfers or by the issue of revenue bonds. Without such executive control the head of a department may defeat the will of the council.

Administrative control of the comptroller requires the keeping of an account with each appropriation, against which is charged all vouchers passed on claims against the same, and an accurate account of contracts and orders outstanding which may ultimately become a charge. Such accounting is necessary to prevent the overreaching of authority on the part of department heads. To these accounts reference should be had in the audit of claims before they are vouched for payment. If contracts and orders exceed the authority given, the comptroller not only has the power to refuse to draw a warrant, but it is his duty to do so. In fact he becomes personally liable for vouching unauthorized claims. Nor can the contractor compel the comptroller to act, since any action brought must be in the nature of a proceeding citing the comptroller to appear and show cause, a defense to which action is found in evidence in his own hands showing that the head of the department exceeding his authority acted ultra vires.

\section{TRANSFERS AND REVENUE BOND ISSUES}

The bugdet is essentially an authority based on estimates. These estimates may not be well founded. By means of the budget the legislature seeks to effectively direct and control the action of administrative officers. In this its power is complete, as it may limit expenditure in every detail which it would directly control. Should its estimate be found to be inadequate or too large, it can at any time modify the authority originally given in so 
far as the officer to whom authority has been given has not incurred obligations which operate as claims against the funds voted. These modifications usually take the form of transfers - a certain amount, by subsequent act, being withdrawn from one use and definitely appropriated to another. Modifications of this kind, however, should be made only after due consideration, since the head of the department should be permitted to make his plans and execute them without unnecessary interference being held responsible for results. Before transfers are made at the request of the head of a department, careful scrutiny should be given to determine whether or not the will of the legislative body is not being defeated by subterfuge, one function or activity of public importance being weakened for the benefit of another in which the administrative head may have some special interest.

Should the function or activity for which supplementary support is asked prove a worthy one, and no appropriation for another purpose be available, the legislative body still has authority under many charters to issue bonds in anticipation of future levies. As such issues must of necessity become charges against future revenues, the legislature must have sufficient reason to cause it to forestall the activities of future administrations by support given to the present. The practice when regularly indulged in leads to an increase in the funded debt - a result which is wrong in principle, being in the nature of the capitalization of expenses, or the deferring of the operating cost of the present to be met by a future generation. Such a practice if continued must ultimately impair the credit of the municipality. Only emergencies which may not be foreseen should warrant the issue of bonds for current expenses, the retainment of which should be immediately provided for in subsequent budgets and tax levies. 


\section{A Business Man at the Head of a City's Business OFFICE $^{1}$}

WE have just heard from the business head of a great public corporation that he is not a reformer - that he is simply trying to give to his city a business administration. I do not know just what opprobrium is attached to the word reformer as used in this strenuous denial, but if Comptroller Metz succeeds in redeeming his pre-election pledge, i.e., if he succeeds in doing what he affirms he is still striving for, - he will prove the greatest among reformers. If he fails, then must not he accept for "the business man" some of the odium attached by him to the term "reformer"?

Two years ago the comptroller of the city of New York was installed in its central business office - an office through which about $\$ 500,000,000$ of business passes each year for his approval - an office designed to protect the city from loss on this great volume of transactions - an office no less important than that of the mayoralty. Comptroller Metz was elected on the issue of "a business A business man for the head of a city's business office." man's admis- He came to the task with a wide business sion of failure experience, and a reputation for accomplishment; he has deroted himself to the office with the same energy and ability that applied to his private affairs has placed him at the head of large industrial and com-

${ }^{1}$ Address before the City Club of New York, February 12, 1908. 
mercial undertakings. He has spent long hours in the city's service; he has not only worked alongside the clerical staff of the department of finance during office hours, but day after day he might be found applying himself to public affairs after his office staff had gone home and after three-fourths of the public whom he served had left their private businesses. How signally he has failed to keep his pre-election promise to date, we have his own words. He has just told the members of the city club an organization whose business it is to take note of every neglect to civil duty - "that the city's money is simply being thrown away"; "that the comptroller is practically helpless to protect the city except there be a complete reorganization of the department of finance and a complete revision of the city's administration and accounting methods"; "that the comptroller is being peddled every day in the week"; that by hard work he is able to "catch a few things here and a few things there, but the mass of details is so great that with all the vigilance one man can exercise the city treasury is being plundered from all sides."

The confession, startling as it may seem, carries with it a hopeful lesson in civics. When, in our political thinking, we shall have reached the point of considering the The lesson machinery and processes of public business, which his fail- as well as the character of man who is ure carries placed in control of the business office, when we accept the conclusion that a relatively incompetent man with a superior instrument may accomplish more than a highly competent man with an inferior instrument, when we appreciate the fact that graft is to be accounted for by the evolutionary theory of the survival of the fittest, and that the "good man" who is elected to office, and the "business man" without means 
of governing intelligently, as compared with the party boss and his army of well-organized and well-informed grafters, are unfit, then we may know why it is that a Tammany chief makes the better mayor and a more efficient alderman.

A subject of present consideration is the city debt, and in this relation the comptroller has made public this evening a new debt statement. As a preface he tells us that for two years he has tried - by use of the accounting means at hand, and with the assistance of one of the expert accountants in the department of finance - to definitely establish the amount of the city's outstanding

Another side to the subject of municipal institutions obligations, but that the best he can say for the statement just made public is that it is probably within $\$ 20,000,000$ of the truth. Considering the fact that the city of New York has the constitutional debt limit staring it in the face, perhaps nothing that Mr. Metz could say would better support the conclusion that the instruments with which he has to work are not what they should be. After listening to the address of the comptroller on the volume of indebtedness, and address of the president of the department of taxes and assessments as to the method of determining the debt limit, if there is anything that I might add, it would be to tell you why a "business man" may find himself helpless in the city's central business office, and how the method of business organization and procedure may affect the problem of municipal debt.

WHY A BUSINESS MAN MAY FIND HIMSELF HELPLESS IN A BUSINESS OFFICE

Before considering the reasons for the present helplessness of our "business man" at the head of the city's central business office, let us get in mind just what may 
be expected of him under the present charter. On its administrative side, New York has had applied to it more charter remedies for incompetence and graft than any city in the United States. The state assembly has usually been controlled by an opposition political party. Not a legislature has closed its deliberations without acting favorably on some proposal which has proceeded from the opposition in the government of the city. The most advanced theories of organization looking toward increasing efficiency and fidelity of municipal service have been enacted into law, and as the publicist has turned from theories of laissez-faire to those of centralized power and centralized administrative control, central administrative authority has been strengthened that responsibility may be laid on the chief executive heads. The mayor is Legal powers made personally responsible for efficiency with which our in the municipal service on the operative business man side of the government. The comptroller was clothed is made responsible for passing on all financial relations of the city. Legally, he is in much the same relation to the city as a trustee of a great private corporation who is vice-president, chairman of the finance committee, and, under the constitution and by-laws, responsible to the board and stockholders for the administration of all the central business functions, including (I) the making of contracts and purchases; $(2)$ the issue and retirement of bonds and temporary loans; (3) the purchase of real estate; (4) passing on construction and betterments; (5) the collection of all revenues and accounts receivable; (6) the settlement and payment of all claims; (7) the guardian of all trusts for the benefit of the municipality or for which he is liable for an accounting.

That these responsibilities may be enforced $(a)$ he 
has been given a seat on the board of aldermen; $(b)$ is given three votes in the board of estimate and apportionment, is made one of the three sinking fund commissioners; (c) is made one of three trustees for the selection of city Legal means of depositories; (d) is made one of the three enforcing trustees for the head of a great central powers

purchasing agency (the board of city record); $(e)$ is required to be present in person or by representation at the opening of all bids; $(f)$ must pass on the sufficiency of security deposits and must certify all contracts before they become valid; $(g)$ must approve all claims before payments and sign all warrants on the city treasury; (h) must issue all bonds; (i) audit all collections and revenue receipts; (j) prescribe the forms in which all accounts and all financial and statistical reports shall be kept and rendered in every department and by every officer and agent of the city. Such are the powers with which our business man was clothed when he accepted the position of comptroller of the city of New York.

Among the first public utterances he announced that he wanted the public to understand that he was no "rubber stamp," that before he placed his name on an Conditions which have official document he would know the facts. which have With all these powers, with ordinances, caused the busi- budgets, and resolutions authorizing con-

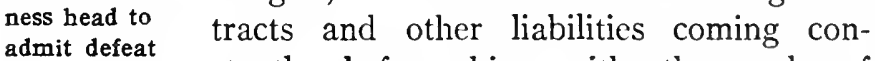
admit defeat stantly before him, with thousands of proposals for bids, with as many thousands of contracts to be certified, with hundreds of claims to be passed each day and as many warrants to be signed, with millions of bonds to be issued, markets and other properties to be managed, permits to be granted, leases to be entered into, by what organization, and by what instruments in his hands, might he be able to perform these duties with 
intelligence? What are the administrative conditions which caused the comptroller to admit that he has been "peddled"; that he has been used as a "rubber stamp," while "the city's money is simply being thrown away"?

To perform the functions of his office and properly protect the city, there must be a system of official intelligence as far-reaching as his responsibilities. Every ordinance or resolution proposed should be accompanied by a complete and well-digested brief as to the facts on which action is to be based. And for the accuracy and completeness of this report some one in subordinate position should be held liable. With every contract to be certified there should be a complete statement of the

Administrative conditions essential to the intelligent exercise of powers unencumbered balance of the appropriation or fund against which it is to be charged; every voucher to be passed and every warrant drawn should be accompanied by such evidence as would enable a court to pass on its justice and legality; every new issue of bonds should be accompanied with a thorough statement of present indebtedness; every collection made should be audited with respect to competent evidence of the amount due and which should have been collected. To the end of protecting the city against loss and waste, the comptroller should have within his reach complete information as to properties and equipment owned; he should also have at hand the means of readily determining the city's liabilities and responsibilities as trustee.

Whatever his aversion to serving as a "rubber stamp," the comptroller soon found that by force of circumstances A system which he was bcing used as a convenient tool of a compels official great system of private gain which made ignorance

official ignorance its opportunity. Instead of intelligence being focused in the official who is respon- 
sible under the law, knowledge of the city's business was centred in a number of small local groups of civil service employees, who in turn, through personal contact, kept those in outside political affiliation informed; between the civil servant and the central office there was a wall so inpenetrable as to be impervious either to light or to sound. Instead of the records containing evidence which would enable our business man to know the exact status of transactions, the only way provided was a process of inspection and detection which would ignore and go behind all records. Even this service depended for its success on personal fidelity to the central officer, and most of the inspectors being attached to several local centres of information, no clue was left by which central business intelligence might be gained or local business responsibility might be fixed.

To be more concrete: Although the comptroller was legally responsible for the certification and the validation of obligations incurred in excess of the debt limit, millions of dollars of liabilities were not set up on the books of the finance department: (I) there was no accounting record of condemnations authorized, although by such acts the city obtained legal title and became liable for the payment of the cost of such properties; (2) there was no accounting record of contracts for the purchase of real estate; (3) there was no accounting record of noncontract claims filed against the city or of actions pending or of judgments obtained for damages and on other noncontract claims; (4) there was no accounting record of Lack of ac- open market orders, although millions of counting rec- these were outstanding, as charges against ords showing funds and appropriations, and which in liabilities many instances overdrew unencumbered balances; (5) there was no record of orders issued against 
contracts or of engineering estimates of work completed under contracts for construction, although it was the practice to register these contracts against bond fund and corporate stock authorizations, before the bonds were sold and before any funds were available with which to meet such claims when presented for payment; (6) there was no accounting record of invoices payable for goods received and used by the city, thus constituting a legal claim for debt although there were millions of such liabilities outstanding, in many cases in excess of authorization; (7) that there was no central accounting record even for vouchers payable, although there were millions of such vouchers in the departments and in the hands of the bureau of clerks and auditors of the department of finance; (8) that the first knowledge which the chief accountant and general bookkeeper of the central accounting office had of any claim against the city or of any charge against appropriations or funds was after a warrant had been prepared after the voucher had been audited, ready for the signature of the comptroller, and this in many instances was months after the transaction out of which the claim arose - possibly months after the voucher had been certified to the department of finance. This left each local group of civil employees who had any contact with the city's business, and the heads of departments and bureaus, entirely without central control, free to deal with the city's creditors in any manner they chose; it also left the comptroller and the mayor in such ignorance of liabilities against the city that when a bond issue of $\$ 40,000,000$ was planned to meet current demands during the next three months, the city was unable to keep faith either with bond buyers or with other creditors.

Generally speaking, the records pertaining to every branch and division of the business for which the comp- 
troller was responsible were in the same primitive and chaotic condition. Not only was there an utter lack of records in many essential particulars, but such accounts as were kept in the department of finance bore no direct relation to the detailed records of the several departments

No relation between the accounts in departments and those kept in central office over which the comptroller was legally responsible for this exercise of control as to their accuracy and as a protection to the city against the infidelity of employees. The appropriation and fund accounts kept in the departments were charged with vouchers payable. In the department of finance no account was taken of vouchers; all charges were made from warrants; between the voucher charges and the warrant charges were all vouchers in transit, all vouchers held in the bureau of audit, all corrections of vouchers and warrants, and all transfers of which the department received no notice. Moreover, the warrants payable were registered in the department of finance by boroughs, while the control to be exercised was by departments. If a studied effort had been made to defeat every possibility of accounting control, a more effective method could not have been devised. The most generous interpretation that may be given to the accounting procedure in use in the department of finance is to assume that those who have acted in the capacity of experts had no support in such efforts as they may have put forth to bring system out of chaos since the time of consolidation, to ascribe the result to a process of evolution, the directing forces in which had been in organizations and alliances interested in defeating official intelligence. Like Topsy, the business procedure had "just growed," and there were in it as many kinks as in Topsy's unkempt hair. 
HOW ORGANIZATION AND METHODS OF ADMINISTRATIVE PROCEDURE MAY AFFECT MUNICIPAL DEBT

Returning to the problem of municipal indebtedness: The organization and methods of administrative procedure may affect municipal debt in one or more of three ways: (I) Through lack of information as to the amount of the debt, the constitutional limit may be exceeded and the price of bonds affected by casting doubt on the legality of issues. (2) Through inability to exercise central control over expenditures, the amount of the debt may be largely increased $(a)$ by the payment of unjust and excessive claims, and $(b)$ by the charging of current expenses against special revenue bond funds and corporate stock funds. (3) Through inability to exercise central control over revenues and collections, (a) the city may obtain money on revenue bonds in anticipation of taxes which ultimately must be refunded by issues of permanent debt, and $(b)$ revenue to which it is justly entitled for meeting expenses and the reduction of debt may not be collected.

The first of these results has already been discussed at length by the comptroller. Twice during the last year the city has been unable to keep faith with bond buyers on account of the amount of unknown liabilities which Doubt may be suddenly became known after the treasury cast on legality had been replenished. With the city close of bonds to, if not exceeding, the debt limit, the market for every issue offered must of necessity be affected. The principal investing constituency to which the city must appeal is the savings banks. Approximately $\$ 300,000,000$ of the city's issues are reported to be in institutions of this class. If any question may exist which would take these purchasers out of the market, or what is still more to the point, cause state superintendents of 
banking to discredit the issues at present held, the city would be seriously hampered in its borrowings, and the taxpayer would have an increased burden to bear.

The second result (inability to exercise central control over expenditures) is even more serious. By the present method and procedure the audit required by charter is Increase of a farce. If evidence were present, each debt through signature affixed to a considerable proporfailure to audit tion of the warrants drawn on the treasury would constitute a crime. A proper audit of a claim is the judicial review of the evidence supporting it for the purpose of passing on its legality and its justice. If, in the opinion of the auditor, the legality of the claim is not properly supported, it is his duty to reject it; in case the amount claimed is not properly supported, it is the duty of the auditor to withhold decision till the evidence is complete and then to reduce the amount to which in his judgment the claimant is justly entitled. This is the charter purpose in creating the bureau of audit in the department of finance and making it independent of all administrative interference in the exercise of its discretion. The action of the chief auditor is subject only to review by the comptroller, and after him, by the courts.

What is the character of evidence on which more than $\$ 100,000,000$ worth of claims are passed each year by the bureau of audit? Over one-half of this amount is in The present the form of pay-rolls. With these, no eviaudit of claims dence whatever is presented as to service a farce rendered. The approvals of heads of departments are accepted although it is known that no time records are kept and no certificates are cxacted from those who have knowledge as to whether employees are even present at the respective stations named. Between the 
head of the department and the bureau of audit the certification of the civil service commission is interposed, but this is formal except as to the fact that the employees are properly listed. In passing this class of claims there is not a line of evidence reviewed, and not a signature of a person affixed to a document who has any knowledge either as to the validity or the justice of the claim. Even in the department of finance, no record is kept from which a pay-roll may be reviewed, yet a person falsely certifying may be held responsible for forgery or for conspiracy. Men have been away from their posts for weeks at a time in the bureau of audit itself, and others have been in a drunken condition at their posts, yet the pay-rolls have been passed. It is no wonder, therefore, that men on the city pay-roll are regularly employed as bartenders and in other occupations, not even taking the time to come to a city office to draw their pay.

Claims for supplies purchased are regularly passed with quite as little evidence. To the claim is attached no competent proof that goods ordered are received in the quality and quantity required. A receipt may be attached, but no method is provided for determining whether Claims passed for supplies without evidence of goods received

the receipt is false. Goods may be short in weight, they may be below grade, they may not have been delivered at all; yet no method is employed in the department for locating responsibility for authorizations to audit. Certificates are regularly attached when, in the very nature of the circumstances, the one certifying could not receive the goods. As a protection against this lack of accounting procedure in the departments for holding purchasing agents, storekeepers, and others responsible for fidelity, the bureau of audit has provided itself with a corps of inspectors who are required to certify to the facts of 
delivery, etc., but no notice is received of the existence of an order, an invoice, a delivery, or a claim against the city to be audited until the goods have been consumed, the repairs have lost all marks of identity, or the construction has been covered up. Nevertheless, the inspectors of the bureau assume to affix their certificates as evidence for the auditors to consider in passing the claims, the auditors knowing that an actual inspection was not made.

Not alone is the loss to the city due to such procedure to be counted by the millions of excessive and unjust claims actually paid on the approval of auditors of the Inspections department of finance and on warrants used to further signed by the comptroller relying on such graft approvals, but the practices which have grown up have practically driven honest competition for city business out of the market. A large portion of contracts are handled by those who keep in touch with persons whose influence is a guarantee of payment, without embarrassing delays and inquiries. Those who will not resort to such practices refuse to make contracts and deliveries except at prices which are unfavorable to the city. Instead of being able to purchase to great advantage by reason of the large quantities consumed, the city pays higher prices for goods than the smallest consumer.

Indirectly the city debt is affected by the excessive expense to which the city is put by these practices. Directly the city debt is increased by the false charges made to Debt increased corporate stock and revenue bond funds. by false If a horse is purchased, it is purchased out charges to cor- of monies obtained by a sale of fifty-year porate stock bonds, although the life expectancy of the horse may not exceed ten years; the harness and the carts are purchased out of fifty-year bonds; the oats fed to the horse may be purchased out of fifty-year bonds; then as 
a means of supplementing the supply of fertilizer used to keep the grass green about the stables, horse manure is purchased out of fifty-year bonds. It has become a regular practice to direct as much of the expenses as possible to corporate stock and spend revenue bond funds as a means of making the appropriation go farther. It has been roughly estimated that not less than $\$ 25,000,000$ of the present debt of the city has been incurred for current expenses, in violation of law, and with the approval of the comptroller and his auditors.

Again, the debt of the city has been swelled by excessive prices paid and extortionate claims allowed, which in their nature are directly chargeable to corporate stock. Among these are contracts for construction and purchases of real estate. In conversation with persons having knowledge of municipal construction work - contractors and engineers - the lowest estimate received of the percentage which the city has to pay for the structures and equipment above what the same structures and equipment would have cost private corporations was twenty-five per cent. Several of these estimates ran between fifty per cent and one hundred per cent. The amount of the excess will never be known for the same reasons that, with the

\section{Extension}

through con-

tracts present method and procedure, the amount of excess paid on supplies may not be determined. But certain it is that so long as the amounts of these claims passed, and the contracts of construction may not be directly controlled from a central business office, responsibility for this form of graft may not be fixed, and the city will have its ability to provide itself with other needed improvements reduced by the amount of the added debt incurred. In purchases of real estate many cases of extortion have become notorious. The one thing lacking in this, as in other unjust 
claims which have been audited, is evidence - evidence which will fasten responsibility, and without which the comptroller may not intelligently exercise the functions of his office.

Neither is there any method installed and administered under central accounting control which will hold persons responsible for properties and goods in their keeping. Equipment may be neglected or destroyed, stocks of goods wasted or given away without detection. With millions of goods delivered to storehouses each year there Inability of con- is scarcely a store account kept in the city troller to fasten from which the storekeeper may be held responsibility accountable for goods received and disfor infidelity bursed. An incident is told, the truth of which cannot be vouched for, but which in its possibilities will serve as well to illustrate. A stock of goods is said to have been removed from one storehouse to another; it is related that the stock consisted of metal goods and tools of considerable value. As the drivers were going along the street, a boy on each wagon is said to have been busy dropping tools and castings, while a wagon belonging to a private party followed after picking them up. In most stores this device would be unnecessary, as considerable amounts might be diverted without any one being held even for dismissal from the service.

Let us turn to the third general method of effecting this debt - by lack of control over revenue. It is through revenues that sinking funds are created. Many of them have been pledged by the city to this end. In the water department all surplus revenues, outside of Manhattan, Sinking fund go to the sinking fund. The expenses of the revenues may dock department are paid out of corporate be diverted

stock and the revenues go to the sinking fund. Over these revenues, the comptroller has no means 
of exercising control. In the water department, for example, there is no way for the comptroller to know whether the charges have been properly made, or whether the cash returned corresponds to the charges shown on the books. In fact the charge ledgers are never balanced. The revenues from docks and ferries were not under central control and the receipts are not audited by the comptroller. Over the bureau of city revenue, controlling accounts have been established by the general bookkeeper, but these are set up from the report of the superintendent of markets as to what they should be, and then he is given credit for what he turns in. These controlling accounts serve no administrative purpose, and the receipt vouchers are not audited to determine that the amount returned is what should have been collected.

An example of the character of records and evidences available for the audit of receipts is found in the bureau of licenses - a branch of the mayor's office. Over thirty different classes of licenses are issued from this office in denomination from $\$ .25$ to $\$ 500.00$. These are all written from a common form of printed blank license book. As the license is issued a note is made in the stub to indicate General fund the class and amount. These stubs are revenues may used as a basis for checking the cash book. be lost

In many instances licenses renewed are issued at half the rate charged for originals. On the stub, renewals are indicated by the letter R., originals are indicated by the letter $\mathrm{N}$. As the old licenses expire and are surrendered, instead of being preserved in the office they are regularly thrown into the waste basket, thus destroying all original evidence and leaving the stubs as an undisputed record. 
CONDITIONS UNDER WHICH CENTRAL CONTROL MAY BE MADE EFFECTIVE

With admissions of inefficiency Comptroller Metz has indicated the business man's remedy - viz., "a complete reorganization." Admission of failure to redeem his campaign pledge during the last two years is not for him an admission of defeat. His two years of experience he proposes to turn to public advantage. What is the programme announced for the next two years? Recognizing neglect of their plain charter duties on the part of his predecessors to provide the means of exercising control over the financial transactions of the city, the controller purposes: (I) to so reorganize the department of finance as to equip it with the mechanism of accounting control; (2) to so revise the accounts as to enable those in controlling position to determine the accuracy with which departmental accounts are kept and the fidelity of employees responsible to the city for an accounting; (3) to devise and install a method and procedure of doing business which will provide the evidence necessary to the determination of the justice of claims against the city and responsibility for any failure to provide such evidence; (4) to reorganize the bureau of audit and revise its methods in such manner that such claim approved will be considered in the light of supporting evidence as to its justice; (5) to provide both the evidence and the means of control over revenues receivable and collections of revenues due the city; (6) under a completely constructed system of accounts to enable the city to get off a true balance sheet and a true revenue and expense account within a few days after the close of each month, and to have such statistical and operative reports made as to enable the mayor and the board of estimate and 
apportionment to exercise executive and budgetary control over the several functions and activities of government.

In publishing this programme the comptroller has set for himself a task which is difficult to execute. It means a complete revision of the methods and procedure of business. It means the training of some sixty thousand civil servants in new ways of doing; it means the establishing under central control of new institutional habits - an undertaking which will require every grain of nerve fibre which the comptroller can command, and an energy which a man of less experience and strenuous habits would not possess. If, after two years, this end shall have been accomplished, then may the electors of the city hope that the "business man" who may be induced to accept responsibility for the comptrollership may protect the city from those who would divert the funds raised for public service to private ends. Then may the citizens of New York hope to intelligently cope with such problems as protection to life, health, and property, adequate education to the young, the management of docks and ferries, and water supply. But so long as the "business man" is forced to accept defeat, what hope is there that the "good man" who has been elected on account of his eminent respectability will be able to administer our great corporation in such manner as to protect the common welfare and reflect credit to himself. 


\section{CHAPTER VIII}

\section{Municipal Accounts - A First Step Toward MUNicipal Reform ${ }^{1}$}

BEFORE the establishment of modern democratic ideals, the common people were little concerned with government. They lived under a régime in which political control was regarded as a prerogative of a privileged class and revenues as perquisites of office. In so far as questions of economy and fidelity of subordinates were considered, these did not seriously disturb the peace of mind of the governed. Against this régime there was revolt on the part of the tax-paying industrial and commercial classes. Those who had been ruled over asserted, and finally by revolution established, the doctrine of popular sovereignty. Increased personal freedom and the power of popular control over affairs of State were purchased at the price of increased civil responsibility. Casting off the bonds of political servitude, those who before had no business to engage their thought other than their private affairs placed on their own necks the yoke of civic duty. And as the demands of civilization have become more exacting the burdens of public business have increased.

THE RESPONSIBILITIES OF CITIZENSHIP UNDER DEMOCRATIC GOVERNMENT

According to the tenets of modern political faith, the people are sovereign; the Government is the corporate

${ }^{2}$ Paper published in the Political Science Quarterly, September, 1904, 
agent through which public welfare is to be concerned. The government at one time monarchical now has its powers and duties circumscribed by constitution, statute,

Popular control over the public corpora- of public servant, its activities are still tion and ordinance. The Government being degraded from regal position to the status further reduced to possibilities of popular control by its own limitations and necessities: As a legal incorporeal being, its primary limitation appears in its inability to act except through officers and agents whose election or appointment is made the subject of popular choice; its encumbering necessity is found in the impotence of its agents to act effectively when not provided with physical equipment - the means of procuring which is indirectly or directly made subject to will of the people.

In political organization, therefore, the people (we may say the business people) have imposed upon themselves responsibility for the exercise of sound discretion both in the selection of political agents and in the voting of supplies; and as a means to an intelligent exercise of these functions they likewise have taken upon themselves the duty of inquiry into the details of adminisIdeals of popular control tration. The two standards of popular judgment and control are found in the business principles of fidelity and economy. Or to state these doctrines in terms of political dogma, the first is contained in the familiar adage - "A public office is a public trust"; the second is as cogently expressed in the phrase - "The duty of the Government through its officers is to render the largest possible service at the least possible cost." To successfully carry these two business principles over into politics, it is not enough for the citizen body to retain to itself the legal powers of control over its official trustees, but it must also provide itself with the means 
of exercising intelligent supervision over the administrative acts of its representatives and agents.

\section{FAILURE TO PROVIDE THE MEANS NECESSARY TO ENLIGHTENED POLITICAL JUDGMENT}

To meet this last condition is what American citizenship has failed to do. Nor is the assignment of neglect one which should be stated in terms of culpability. The American people are not of that frivolous, careless, publicly irresponsive temper so often represented by superficial Failure to pro- observers and ignorant but disappointed vide conditions enthusiasts. When called on to make a of control decision on any well-defined political issue, subsequent years have in almost every case proved the wisdom of "the judgment of the majority." Neither are those in official position the time-serving miscreants that they are too commonly portrayed. The most of those who have risen to positions of confidence and trust have been men of ability, honesty of purpose, wishing to spare no pains to conserve the welfare of the community.

The present condition is in part due to the reactionary laissez-faire policy under which our Government was established. This doctrine was essentially the product of resistance and aversion to conditions which ceased to cxist in the minds of demagogues except after the Revolutionary War. In part, the present situation is due to the Doctrines of laissez-faire agricultural life of a people strongly moral, who were also inspired by a wholesome respect for social well-being. With few community functions to be exercised, with little motive to infidelity in office, with every act of the officer under the public eye, the business of government might well be delegated to any one whose intelligence would commend him, and who could find time and social interest to pay 
attention to public duty. In the meantime, the simple service for common good being thus disposed of, citizen electors devote themselves strenuously to the paramount struggle with nature; they give their attention to private enterprise without official interference or annoying burdens from taxation. Periodically the people came together to hear report from those who had been entrusted with the expenditure of common revenues, and to decide on the public work and public levies of another term.

Conditions have changed. From agricultural employment, we have turned to mining, to manufacture, and to commerce. To this end the people have come together in large working groups, great cities have grown up. The same intensity of purpose and the same strict adherence to principles of private economy and business fidelity which caused the pioneer to react against official control and excessive burdens of state have developed larger and

Conditions

demanding increase in government activities still larger industrial groups around which population has centred. Within a generation national characteristics have become essentially urban. There has been a complete change in social conditions and in demands for public corporate service; but in the strenuous pursuit of private business citizen activities in government have not kept pace with public need. Not until the last few years, when increased burdens of taxation have fixed attention on public administration, have the people stopped to inquire whether multiplied duties and responsibilities of citizenship have been attended to.

As in all business enterprise broader activities require a revision of method to insure intelligent control. Of one fact we feel sure - that there has been much waste of revenue and of resource in the administration of cities. A second conclusion is frequently arrived at - largely 
by inference - that public officials have been faithless. Attempting, however, to base our political judgment on exact knowledge, we strike a vital weakness - we are unable to determine at what points waste has occurred Provision of or to fix responsibility for loss. Evidence methods of con- is lacking. As a result of this condition trol necessary of affairs, neither officer nor taxpayer is able to apply a remedy to prevent extravagance in the use of public funds, or to conceive a plan to insure fidelity of service. In such circumstances many of our most intelligent and public-spirited citizens, after a few spasmodic efforts at reform, have resigned municipal politics to fate, while others still struggling in the dark are seeking a method by which intelligent direction may be given to public affairs. Realizing from evidence at hand that there is lack of economy, or feeling that the civic institution is being made the prey to piratical enterprise, many voices of command are heard in the gloom calling the way, but quite as often damage is done by misguided loyal citizenship as by those who are careless of duty or actively betraying public trust. The prayer of despairing reform crying in the darkness lacks one essential plea, "Let there be light" - the light that may be shed by a better devised system of public accounts and by regular and accurate reports.

ACCOUNTANCY AS A GUIDE TO INTELLIGENT ADMINISTRATIVE AND POLITICAL CONTROL

Accountancy is the science, or in practice an art or profession, which attempts to deal with the data of business. A system of accounts is a method The data of devised by business men, or by their pro-
business fessional advisers, for the purpose of obtaining accurate information about problems of administration 
and stewardship. With the enlarged scope of private business, the advisory aspect of accountancy has risen to the dignity of a profession, the purpose of which is to examine and report a true statement of affairs and to devise, install, and supervise methods of currently and accurately assembling the data of an enterprise in such manner as to give the best basis for judgment for the successful direction of undertakings. Without a system of accounts, successful management of cren our smaller concerns would be impossible; many a bankrupt may trace his downfall to the ignorance which comes from failure to provide a means of enlightened control.

A city carries on business of large proportions - a business so complex in its organizations that, without a complete system of accounts, officers cannot intelligently perform the duties imposed upon them. Without a system of record which will reduce transactions to stateFacts that are ments of final account which reflect adminnot forthcom- istrative results, a large city is hopelessly ing in the dark. Being inducted into office for a short term without a knowledge of affairs which may come from records in which are assembled the data necessary to enlightened judgment, it is a tribute to the ingenuity, integrity, and superiority of American public officers that they have done so well. Many of them have gone to great lengths to inform themselves with respect to a municipal situation which should have been an open book.

Before taking up in detail the inquiry as to what a proper system of municipal accounts may do to lay the foundaClasses of finan- tion for reform, it may be admitted without cial transac- controversy that there are four classes of tions persons interested in an intelligent view of the financial transactions of municipalities, viz.: (I) the 
citizens and taxpayers who are responsible for the choice of officers and who must bear the financial burdens of government; (2) the officers and public agents chosen by electors to manage the affairs of the corporation and who become responsible as guardians of public properties, as well as for intelligent administration; (3) those who have become investors in municipal securities and municipal warrants; and (4) the political scientist and the student of municipal finance and administration. A second assumption may with equal confidence be engaged - that for an intelligent understanding of the affairs of a municipality by any or all of these parties in interest, and for sound thinking concerning the problems of administration, the public corporation should be recognized as acting in two distinct legal capacities, viz.: (I) as a proprietor and (2) as trustee; in each of these two relations there should be a separate and distinct financial record and account.

For the enlightenment of all parties in interest with respect to the acts and transactions of the city whether as proprietor or as trustee the same subjects of inquiry above suggested are present, viz.: (I) that which looks toward economy of administration and which has in mind primarily the relation of cost to service rendered, and (2) that which looks to relations of fudelity or an accounting of officers and authorized agents for the properties Relations of entrusted to them and for liabilities incurred proprietorship by them, for which the city shall become and trusteeship responsiblc. If under a democratic political régime these correctly represent the main subjects of citizen or official inquiry, then it would seem that the following premise is self-evident: that for the purpose of satisfying the demands of all parties interested in municipal affairs (whether inquiry be directed toward an 
understanding of past operations, present conditions, or questions of future policy), the financial data should be collected around these two main subjects (economy and official fidelity), and that in the classification and coordination of such data the transactions of the corporation as proprietor should be segregated and kept entirely distinct from its acts as trustee.

THE PROGRESS OF ACCOUNTING SCIENCE IN RESPONSE TO ADMINISTRATIVE DEMANDS

Responding to the increasing administrative demands of business there have been developed two distinct methods of account. A historical statement may illustrate both the purpose and the conditions under which they have been applied. Scientific methods of accounting were first evolved in private enterprise. For this, exact knowledge and sound judgment were necessary to survival. In private enterprise, some method which would guard the fidelity or faithful accounting for assets and liabilities,

Primitive methods of intelligence and which would insure the strictest economy, was prerequisite. Gradually, as the government and the control of public corporations became more popular, and as the commercial and industrial classes gained and exercised the dominant influence in public affairs, rules of private thrift were translated into principles of public well-being; there has come to be an increasing demand for strict fidelity and economy in public administration. With this demand for intelligent statement of the doings of officers and corporate trustees the methods of financial analysis evolved and employed in public business for the purpose of securing economy and effective control have been to some extent applied to municipalities.

In the development of the methods of accountancy 
there have been four distinct steps. In enterprises which have been under the control of a single individual, and which were not so large that every detail and transaction might not be performed by the proprietor himself, in such small and primitive enterprises the records have been unsystematic, incomplete, and without method in other words, certain memoranda may have been kept, but no attempt was made to employ a method of scientific classification and no strict account was kept. This may be referred to as a state of development in which there was no account.

Proceeding from a condition of "no account" the evolution has been as follows: (I) As enterprises became Evolution of
modern methods entrust agents and representatives with more complex and as it became necessary transactions pertaining to certain portions of the business, a form of partial or incomplete accounts was resorted to which would require a statement pertaining to properties and liabilities or relations of business fidelity. Examples of this kind of accounting are found in institutions which keep nothing but a cash-book. Such a system continues to be used in some small private businesses, and it is the system in vogue in nearly all of our Amcrican cities and is the present method of the British Imperial Government as well as of our own State and Federal Governments. This is what may be termed an incomplete method of single-entry accounts, i.e., a system of entries in accounts showing in an incomplete way the single relation - official fidelity or trusteeship. (2) A still higher development in private business has produced what we may term a complete single-entry system - a system of record in which all the data of financial transactions are first collected in memorandum form and then coördinated in statements of final account, but still a 
system in which the accounts have to do with categories of proprietorship and official trust only. By such a method a strict account may be had of assets, and a statement may be made of liabilities outstanding. This method is well adapted to holding officers and agents to strict account for custodianship, but it contains no principle and involves no classification of items which will give information with respect to any relation of administrative economy. (3) The need and increasing demand for statements which would reflect the various transactions and state them in summaries of expense and financial return (as a means of determining relations of cost to amount of service rendered), and the further need of reflecting the good judgment of managers, led to the introduction in private business of what is known as a double-entry system of accounts. This method or system has two distinct categories, viz.: (I) those of proprietorship and official trust (or asset and liability); and (2) categories of economy of administration (or expense incurred and income accrued). In the first application of such a system to public accounts, however, the records are necessarily incomplete. Omissions are made of certain transactions and financial relations that may take years of experience to install; such a system may be called an incomplete double-entry system of accounts. Example of omissions of the accounts referred to are: Failure to set up reserves against current revenues receivable, where for good reason they are encumbered or made unavailable; failure to account for depreciation or the current wear and tear to properties which have not been repaired, and consequently not made an item of current expense; failure to record accruals of interest payable, consequently not getting the charge within the proper fiscal period; failure to record accruals of expense of administration, leaving 
these to be met by subsequent administrations; failure to set up judgments against the city as a part of current liabilities, etc. The final development of this method of accounting is a complete double-entry system - i.e., a method or system of collecting all of the financial data pertaining to the business and of classifying this under categories $(a)$ of economy, and $(b)$ of proprietorship and official trust.

DEVELOPMENTS OF METHODS OF CONTROL IN BRITISH CITIES

The first marked advances toward modern public accounting were made in response to the need for publicity and for reliable summaries and statements of the financial condition of semi-public enterprises. Among the public acts directed toward this end were those following railway speculation in the fourth and fifth decades of the last century. The abuses which had grown out of this character of promotion in England, and the failures that followed the absence of strict financial control, were the reasons for the enactment of the "companies' clauses consolidation act" (8 vict., CXIX). Under the provision First step of this act, auditors were to be appointed toward a better by the stockholders of the corporations at corporate pro- their regular meeting, and these auditors cedure

were empowered to employ accountants to assist them in making reports, or in framing such reports as were prepared by the officers themselves for the information of the stockholders. The reports of the auditors when appointed were to include a certificate as to the correctness of the balance sheet. They were also to give a "distinct view of the Profit and Loss which shall have arisen in the transactions of the company in the course of the preceding half year." It is furthur 
provided that no dividends should be declared except out of profits, and that dividends should never be apportioned to stockholders when this would impair capital resources.

Gradually statutory provisions requiring the appointment of auditors either by the stockholders of companies at their regular meetings or by the board of trade were extended to include public gas works, public water works, commercial banking campanies, savings banks, university and college estates, judicial trustees, county officers, etc. In the movement toward political reform a local government board was finally created (I $87 \mathrm{I}$ ), which would force upon all county councils, municipal

First application to municipalities corporations, and town councils (except the large cities) audits of accounts and reports to the government of financial operation, as well as of financial condition of local governing bodies. The same spirit of reform and the same necessity for providing a system which would furnish the exact knowledge of details in summaries of resources as a means of aiding administrative direction and control, induced the large municipalities to employ professional accountants to install improved systems of financial records and to audit their accounts periodically.

Theretofore the accounts had been little more than cash-book entries of treasury statements. Reform movements had been directed toward holding the officers of the government to strict account in the handling of public funds - in other words, the books of municipalities and local governing boards had been based entirely on prin-

Limitations of cash accounts ciples of official fidelity, without any attempt being made to obtain results bearing on questions of administrative economy. As before observed, private business of very much smaller proportions had been forced over to the double-entry 
system as a means of self-protection. With the public corporation, however, the rule of survival did not apply, as the government could not be allowed to die whatever might be the cost of carrying it on. Better municipal accounting came as a result of popular demand for administrative reforms which would give the desired service at a lower cost. When taxation became oppressive and it was found that public officials could not give an account of the cost of administration, when functions of municipal government became multiplied and municipal activities had grown too complex to allow of an intelligent grasp of detail by those in control, the futility of the cash-book system became apparent.

From the best records that might be made, and from the best summaries deducible from records of the flow of cash, no notion might be had of the real problems of administration so far as economy and efficiency were concerned. What the officer would know, and what the taxpayer was primarily interested in as a matter of strict Application of economy, was the current cost of governmethods for ob- ment and the current revenue provisions taining better made to meet this cost. As a means of results

knowing present financial condition it was also necessary to have a complete accounting for the various properties belonging to the city (or assets), and a complete statement of municipal obligations. None of these results could be obtained from a current record of receipts and disbursements. The city, following the Imperial Government, had been used to a system of partial single-entry account only, and the larger problems which confronted the administration demanded not only a complete system of financial record and account, but also one which would show operative results in terms of economy as well as transactions of its fiduciaries pertaining to assets 
and liabilities - i.e., a complete double-entry system of accounts.

THE LATENESS OF ACCOUNTING DEVELOPMENT IN AMERICA

In America less progress has been made. Here accounting ideals remained undeveloped long after they had arisen to a basis of scientific classification abroad. Here also financial reports were retained in primitive confusion long after accountancy had become well established as a profession in England and Scotland. This was largely due to the lateness of our national development. During the period that accountancy was being erected to the plane of a profession in Great Britain, commerce

Our agricultural condition and industry in America was fast beginning to feel the need for a method which would insure integrity of summaries of financial result and which would lay a sure foundation for administration of private affairs. As before observed, until the middle of the nineteenth century America was primarily an agricultural community, and the farmer needed no account other than a simple statement of receipts and payments together with a memorandum of credit obligation.

Before 1830 the bank was the only enterprise of large capital and its transactions were treated as cash. To show the gradual evolution of the population from rural to urban employment, the census returns may be adverted to. In I820 the city population of the United States was only 4.93 per cent of the whole, and there were only Recent growth thirteen cities having a population of over of cities

eight thousand. The Census of 1850 shows an urban population of only 12.49 per cent. At this time the American transportation company had become the only concern whose volume of business and 
breadth of organization demanded modern methods, or a complete double-entry system of accounts; after the Civil War, industrial and commercial enterprise came to take so important a place in our national life that the current of population set more strongly to the city - a process of centralization was begun similar to that felt by Great Britain nearly a century before; in I89o about one-half of our population was found by the census takers in the large cities; and in 1900, in the most highly industrial portion (viz.: the North Atlantic States), only 31.8 per cent of the population remained in rural employment.

The sudden development of cities here, the hopeless chaos in municipal administration, the known mal-practices on the part of some of our public officers, and the

Chaos and maladministration the result of ignorance abortive attempts by honest and conscientious officials to locate responsibility as well as to protect themselves against the suspicion of corruption which the public had come to entertain toward all those connected with local government, has, within the last two decades, raised up a universal demand for municipal reform, which has brought the combined intelligence of honest citizenship to bear on the solution of the problem.

Advance steps first taken were in the nature of constitutional and legal reforms. By this method it was hoped to so hedge the officers of government round about with restrictions, checks, and balances as to make it Legal steps taken most difficult for them to go wrong. Such was the first reaction against official infidelity. In the United States, as in England and in Continental Europe, attention was first called to attacks on the public treasury and to the subversion of public funds to private use. To protect the citizen taxpayer against misappropriation of funds contributed, the 
first movement toward constitutional and legal reform was the creation and the election of an independent treasury official; and the first method introduced to detect fiscal abuses was the installation of a complete system of record of treasury transactions and the publication of detailed treasury reports. Legal check Checks and balances after legal check has been added to little or no avail. The changes made in the constitution could not be more than inhibitive in character and tended only to weaken official capacity and to still further confuse official intelligence, while the method of accounting in vogue served only as a protection against fraudulent inroads on the Treasury.

\section{THE NEED FOR ACCOUNTS - A FIRST PREMISE TO REFORM}

The need for a system of complete accounting in American municipalities as a first premise to municipal reform has in recent years been enlarged on by many. This view has come from those who have had to grapple with administrative problems of large cities, and the awakening has not been without result. Efforts toward legal reform are being shifted from constitutional and legal

Need for accounts a need for complete and accurate information restrictions placed on official conduct or negative measures, to those which will provide for greater efficiency and constructive activity - measures which will secure a better understanding of municipal activity and administrative results. The most fundamental of these are directed toward a more enlightened system of official records and reports. The city of Boston, for example, under a revised ordinance of 1898 , empowered the city auditor, with the approval of the Mayor, to designate expert accountants to examine the books and accounts periodically. This was to the end of obtaining a critical 
review, and resulted in a more intelligent report, but did not contemplate the installation of a new system of control. In I 900 the State of Missouri appointed a special commission for much the same purpose. A number of States have inaugurated movements to create a permanent board or officer of central control over municipalities and local government bodies, with powers similar to those enjoyed by the local government board of Great Britain. The State of Ohio furnishes an example in point: It has enacted a complete municipal code which applies to the principal cities and towns of the State, giving them uniformity of administrative organization, in addition to which the State has organized under the State auditor a bureau of uniform accounting with power to prescribe forms and systems and to compel their adoption by all of the municipalities. Other States, as Wyoming, have introduced uniformity in accounts for county and town organization.

Some of the American cities, reorganizing their helpless administrative condition with their antiquated and unintelligible records, within the last few years have taken the steps necessary to have installed systems of account which will give a complete and accurate statement each month of revenues and expenses as well as assets and liabilities, and relate these definitely to the annual budget. The first to do this was the city of Chicago; this became effectRecent steps ive in Ig02. The example of Chicago has taken to install been followed by Houston, Texas; Oklahoma a complete sys- City, Oklahoma; Minneapolis, Minnesota; tem of accounts Rochester, New York; East Orange, New Jersey, and a number of other towns of importance. Many are considering the installation of a complete system devised for that purpose. Generally speaking, however, American municipalities and local government 
bodies still attempt to work out their administrative problems from the cash book, and even in States where the law requires a statement of "revenue and expense," attempts are made to reach such result through subsidiary schedules, making the treasury statement of receipts and disbursements the principal feature of account and report. Such a method never has and never can reach main problems toward which municipal reform is directed, the purpose of accounts being to furnish the information necessary to intelligent administration. To do this the accounts must be organized and classified in such a way as to reflect administrative problems. The cash book or treasury statement cannot form the basis for such consideration.

Few municipal accounting officers have yet risen to the dignity of professional accountants. Most of them are in temporary political positions and have been given places as a reward for partisan service. If we judge from the results of their work the conclusion is inevitable that few of them have such a knowledge of the principles General adhe- and methods necessary to a complete doublerence to inferior entry municipal accounting that they appremethods

ciate the futility of the cash-book system. Even in cities like New York and Boston the cash-book is still retained as a central feature of account and report - their published statements show little else than the flow of cash as it is exhibited in summaries of receipts and disbursements. The additional information given bears on relations of fidelity and proprictorship; but they furnish little or no information which may serve as a guide to judgment as to economy or efficiency. The assumption is still engaged, that the chief aim of municipal accounts and reports is to know whether fiscal agents have gone wrong. Neither the officers of munici- 
palities in responsible positions, nor the taxpayers, have any means of determining from such a system current expenses incurred (annual cost of administration), nor revenue accrued (current provisions made for covering such cost). There is no intelligent guide for making appropriations - no means of ascertaining revenue surplus or revenue deficit as distinct from cash balance no logical basis for budgetary estimates from which a rate of taxation may be arrived at.

OBSTACLES IN THE WAY OF THE INTRODUCTION OF BETTER SYSTEMS OF MUNICIPAL ACCOUNTS

The obstacles in the way of the introduction of better systems of municipal accounts are many. In the first place, a clear appreciation of the need is not general even among the most enlightened citizens, and for that matter,

Divided responsibility

among political scientists themselves. Many still cling to the more primitive method of control (restricted political power), rather than that of centralized official direction and better equipment for intelligent and effective administration. The underlying principle in a government of divided executive powers is to insure fidelity by pitting one officer or department against another. This method assumes that the chief aim of reform is to prevent fraud and autocracy, and the method was well adapted to the political and social conditions of a century past. The problem of to-day, however, is one of increased administrative efficiency. This cannot come from a policy of negation. Administrative efficiency must be associated with responsible but highly centralized control, which becomes effective only when intelligence in an administrative head is reflected from such a record of corporate transaction as may lay the foundation for the exercise of cffective official discretion. 
Another obstacle to reform is found in the very element which gives to democratic institutions their stability, viz.: in what we may call institutional inertia or custom. What habit is to the individual, custom is to a society living under popular government. The individual having first chosen to act in a certain manner under conditions Social inertia present, the action appearing to be most advantageous, he continues to act in like manner under like conditions. But with each repetition of the act both mind and body acquire such increased facility for acting in this particular way that it will require a constantly greater effort to act in any other manner. By the laws of habit, conditions remaining the same, the repetition of an act is of constantly increasing advantage and the habit continues unchanged. The same has been postulated of society in its collective activities. And it being true of the individual, on the principle that what is true of each of the parts is true of all, the conclusion follows. In social activities, however (i.e., the activities of individuals coöperating with each other), this fact becomes much intensified for the reason that it requires far greater effort for a number of men to agree on a new plan of coöperation, than for one man to make a decision for himself; the collective habits or customs of men acting in coöperation, therefore, are the more firmly fixed. And as the individual will put forth the effort necessary to change his habits only when, by change in environment, the disadvantage of continuing to act in the old way is greater than that of effecting a change by cultivating new habits, so with society - a new custom is acquired only when the disadvantage of the old one becomes practically unbearable.

A third, and perhaps one of the most potent deterring factors, is the cost of installation of an adequate system 
of accounts. A city in its business organization is much like a large industrial plant. Around its many differing but

Labor and time necessary to revise old methods allied functions are organized its departments. Each department is necessary to the successful operation of the government; each requires highly specialized equipment and a complete record of departmental transactions as a means of intelligent supervision; but all must be moulded into a general centralized system before the general manager (or chief executive) may obtain a proper view of administrative results and execute official functions in a vigorous and effective way. Operating under the older theory of division of powers, many of the departments in the past have acted independently; and acting in this manner they have organized the work and evolved systems of records peculiarly their own. Some have kept nothing but memoranda of transactions, others have reduced the memoranda kept to classified statement for their own advice. Few of the cities, however, have what may be called a system of central accounts, and the departments themselves are opposed to unification.

In such circumstances the devising and installation of a system of accounts based on the theory of centralized control requires the best professional service; and before this may be successfully undertaken, some one who is able to comprehend the problems of administration in all its bearings - some one who is competent to exercise judgment with respect to the technical aspects of administration, some one independent of all departmental traNecessity for ditions and official influence, must make a professional assistance and tail of service which is to be brought under advice the single executive head, as well as of the powers and duties of allied governing bodies. The cost 
of devising such a system of effective control - one which will at the same time enforce fidelity of service, make possible the strictest economy, and give the facility to departmental operation - is not inconsiderable. But the cost of devising a new system of account is not the most expensive part of the work. Before the city may avail itself of a system devised, it must be installed and supervised. That is, the past records (such as may have been kept) must be closed, and the financial results transposed into the new system. In so far as the old system has failed to account for properties and financial obligations these must be set up, after which the ones devising and installing the account must train the clerical staff, employed by the city, in the use of the new device to make it effective. For this character of professional service, the citizens of $\mathrm{mu}$ nicipalities are usually unwilling to pay.

It is not an uncommon thing for a private corporation to pay large sums for an examination and improvement of a system already in use - and one too far superior to those employed by municipalities. This, by them, is considered a good business investment, one made in the interest of permanent cconomy and higher working efficiency. In any large concern, public or private corporation, a large part of the general expense of operation is in the clerical service necessary to the keeping of records of The example transactions and classifying them and bringof the private ing them into summaries of administrative corporation

result. A manufacturing concern will pay more for an improved cost-keeping system alone, than the largest of our municipalities are willing to expend for an entire modern accounting plant. 'This was done that the manager might know how much each item of product has cost. By means of a system of record that will trace an individual product or process from place to place and 
record every item of expense, the general manager may intelligently ascertain where expense may be reduced without impairing working efficiency, may fix a selling price, and know how much will be the profit or loss at the price sold. The highest economy in municipal administration can come only when public service is reduced to a basis of the unit of cost. A municipality may have a business many times larger than a private concern and be almost entirely devoid of books of general account which will show administrative relations, yet the municipal officer, fearing popular disapproval, is not willing to incur even a small portion of the expense of this private concern for the record equipment, to the use of which it has in large measure owed its business success.

The benefits of an improved system of accounts are largely to be found in the future. Yet it is a significant fact that so far as accounting reforms have been introduced, the cities installing them even at large expense have profited by them by direct saving the first year after their installation, more than the entire cost. Another

The benefits to be derived

fact quite as significant may be adverted to: that in each case where complete systems of account have been installed, those who have undertaken the professional work, seeking to meet the conditions imposed by the unwillingness of citizens to incur expense, and contracting to render the service at a fixed price, have done the work at a loss; the actual cost of doing it has exceeded the contract price received. With the attitude of cities averse to making an expenditure necessary to equip themselves with more effective administrative machinery, and with the experience accountants already had in the devising, installation, and supervision of new systems, there seems little hope that any very radical reforms will come before citizens are forced out of cus- 
tomary habits of thought and a change of attitude has come about which will recognize in municipal business the same conditions for precedent to administrative success as are commonly accepted to be necessary in private corporate affairs. 


\section{CHAPTER IX}

\section{Municipal Credit and Accounting Reform ${ }^{1}$}

THE vice-president of the City National Bank is among the latest to call attention to the declining credit of the city of New York. The increase in the bonded debt of the city from $\$ 225,000,000$ to $\$ 600,000,000$ in seven years he does not view with alarm, predicting a revival of confidence as investors come to know more about the true situation. What is by Mr. Vanderlip regarded as a subject for chief concern is the present condition of the city's records.

"Here is this great metropolis, with its income well exceeding $\$ 100,000,000$ annually, undertaking vast public works, issuing millions upon millions of obligations, and presenting a system of municipal accounts that have, even with the improvements already inaugurated, been brought to a point not much short of chaotic."

\section{An arraign-} ment of present methods

"To-day there is no true balance sheet."

"Its so-called balance sheet contains meaningless credits that have been carried from year to year since their disgraceful birth in the corruption of the Tweed Ring."

"In none of the reports of the Controller is it possible to obtain in succinct form an intelligent view of the city's true financial position."

Thus are the city's records and reports characterized in his address before the Savings Bank Officers' Asso-

${ }^{1}$ Published in the Journal of Accountancy, New York, June, 1906. 
ciation. Not infrequently have such utterances come in the past, though usually from a less authoritative source. This is the voice of a representative of one of the largest dealers in the city's credit, laying down the conditions for future investment judgment.

The investor in long-time obligations of the city twenty-year or fifty-year bonds - must look to the prospectively remote ability of the municipality to meet its outstanding credit. Currently it must pay expenses of operation - for the government must be maintained at

The basis of credit whatever cost or sacrifice of other interests; currently it must meet its interest payments; currently it must make its sinking fund contributions. But if in any of these obligations it shall fail for lack of ability to procure adequate revenues, the sinking funds will be first to suffer; i.e., the security for the payment of the principal of the city's debt will be the first to be impaired. This is the reason for the bond buyer's concern at the rapidly rising debt - this increasing need for current revenue for sinking fund purposes, with a limit fixed on taxation.

This long-time creditor of the city is interested in knowing not only what is the total amount and what are the different classes of municipal liabilities, but also what current assets and capital resources are held by the city. $\mathrm{He}$ is interested in a true statement of current assets, as a

Information necessary to exercising investment judgment means of knowing whether the corporation will be able to pay expenses, and have enough of current revenue left to pay interest and meet sinking fund requirements. $\mathrm{He}$ is interested in a true statement of the permanent improvements and equipment, that he may know what use the city has made of funds borrowed, and how its present estate will affect the future revenues and 
expenses. But further than this, he is interested in a true asset accounting in order that he may know whether proper and adequate provision is being made for maintenance and depreciation of properties that should be currently cared for. Is the city borrowing money on long-time bonds to meet present expenses? The classified current report and balance-sheet statement should show this. Are long-time bonds being issued to buy brooms for street-cleaning? Are fifty-year bonds being issued for the repair and repavement of streets, when the life of these repairs or repavements will not be more than a fourth or a fifth of the period which the bonds have to run? Such a condition should be shown by a proper asset and liability and expense accounting. The fact that the current revenue provisions are inadequate to provide for expenses by the amount of bonds so improperly applied to the purchase of supplies and to current maintenance charges, should also appear from adequate reserves set up to meet such expenses. Unless the levy be adequate to meet current charges including all proper expense and depreciation reserves, the income and expense accounts would show a revenue deficiency. This is some of the information that will be required by investors before the city of New York will be able to sell bonds at their full worth, i.e., without the price being scaled on account of the wide margin of risk that lies in uncertainty as to those corporate facts and conditions which should be revealed by a proper system of accounts.

The bond buyer, however, is not the only one to lay The citizen's right to know claim to more exact information concerning the city's affairs. The demand of the citizen was recently expressed editorially in one of our leading dailies as follows: "There ought to be available for use in each fall election a report on the city's 
business resembling those presented to stockholders of leading corporations." This demand includes all the information required by the creditor, but it goes further; the citizen would have reported such additional data as will enable him to judge as to the economy with which public moneys have been expended, and as to the efficiency of public service rendered. The taxpayer would not only know what resources the city has to represent bonds outstanding, but would also know what resources are in hand to represent bonds paid from sinking funds. These funds are the capital contributions of municipal taxpayers. What properties has the city to account for them; or if not properties, then in how far have the current expenditures been reduced by allowing properties acquired to become impaired or by suffering them to depreciate? Has there been a reduction in taxation equal to the depreciation, or have reserves been created for replacement? Has the municipal estate been administered in such manner as will reflect credit upon the officer and will prove economical to the taxpayer?

Mr. Vanderlip is sanguine not only with respect to the future of the city's credit, but also of the immediate prospect of accounting reform. In the present comptroller he sees "a man who recognizes with remarkable clearness the exact situation surrounding the city's credit; one who has the force and energy that gives every promise that great improvement will be wrought." But lest A prediction of through some misapprehension as to the A prediction of task which the comptroller has before
reform him and the unstinted coöperation necessary to the accomplishment of this much desired end, something may be said of the office which he took in January. Speaking of conditions of the records in the office of central control not long since, a man of national 
reputation cognizant of the facts said, "There are on the city's books several hundred accounts which the accountants of the municipality themselves do not know whether they represent assets or liabilities." This may seem somewhat startling, but not less so than a recent expression of one old in the city's service who vouched for the statement that "there were between one and two hundred accounts on the general ledger alone, representing millions of dollars, concerning which those in the comptroller's office know practically nothing." These accounts are balances inherited from pre-consolidation times, and have never been analyzed.

That those who are at present in the comptroller's office are not responsible for the conditions will be understood when it is known that on the occasion of one of the largest boroughs being brought under the present charter, several millions of dollars were turned over to the chamberlain by the borough treasurer, and several wagon-loads of books were dumped upon the comptroller; these books were not in balance and the accountants for the city have not to this time been able to reconcile the cash received with the records.

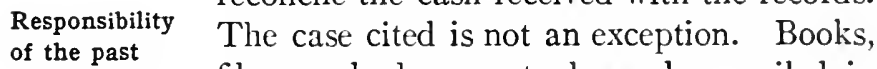
files, and documents have been piled in heaps into the offices occupied by the finance department of the city by the various borough officers after consolidation; the records have been left in most confused condition; the filing space is inadequate; negligence is displayed by the city in permitting its most valuable records to be crowded up in unused corners, or at best packed away in sheet-iron shams for safes, some of which were found to have wooden backs. To walk through this chaos would leave no wonder in the mind of any unbiased observer that the city to-day is unable to pub- 
lish a balance sheet or for that matter even to tell within several millions of dollars the amount of assessments and arrears it has on its books. In view of such a condition we need not marvel so much that some of the books representing revenue assets have not been balanced since $\mathrm{I} 898$, as that the records of cash received and cash disbursed by the general officers of the city since consolidation have been kept clean. During the last eight years there has been a complete balancing record maintained with appropriation accounts, bonds, trust funds, and with cash receipts and cash disbursements.

Much has also been done to untangle the maze of subsidiary records and to analyze the balances inherited from the old books. Yet this work is scarcely begun. It will require years before official knowledge may be gained of all the subsidiary records. And in the nature of things the cost to the city will be great. This, however, should be done and the comptroller should be given the means of unraveling this financial mystery.

But with a mastery obtained over existing records the city will know only what it has inherited; it will not be put in position to liquidate and realize on this inheritance, and to state its financial condition as reflected from the past. The comptroller will still have before him the

The present opportunity task of devising and installing a new system of accounting or of so far modifying the old one that a balance sheet may be currently taken off, and a revenue and expense statement may be currently and economically made. Unless provision be made for obtaining these data regularly and promptly from the current closings of the books, and a system of asset and liability and income and expense accounts be installed which will currently answer the demands of creditors and give to officer and citizen such 
information as to enable them to think intelligently about the business of the city, the municipality will still be under the same disadvantage as is at present the subject of continued comment.

In the boroughs, prior to consolidation, and in the city of greater New York since, the accounts have not been such as to lend themselves to the purposes of creditor judgment nor to the purposes of those interested in obtaining a view of administrative results. Whatever may be

Pre-consolidation records

the multiplication or complication of records of cash received and cash disbursed, when kept with appropriations (the present system), there can be only a statistical approximation as to assets and liabilities, revenues and expenses, and such data as are kept for the purposes of such reports will not be under the same control. Nor will there be the same necessity for keeping them up to date, for prompt reporting, as if these were made subjects of general controlling account - accounts which must be closed and, correctly stated before a trial balance may be drawn off.

Coming down from prior practice and from departmental custom, there are at the present time instances of duplication, triplication, and even quadruplication of accounts representing the same transactions, in each case closing with the same appropriations and funds, but in no case reflecting financial condition or adminLack of system $\begin{aligned} & \text { istrative economy. Much of this energy is } \\ & \text { misdirected. One of the tasks of the comp- }\end{aligned}$ troller is to properly utilize the staff which is at the present on the pay-rolls of the city. Generally speaking, books are kept in departments from which any information may be obtained, but, usually, this is not made available, either to the administration or to the public except spasmodically, and in fragmentary form as statis- 
tically gathered in special reports. The only information that is regularly and currently closed into controlling accounts pertains to funds and appropriations. The balance unexpended of appropriations may be known within a few days after each closing date, but the city cannot tell what amount of obligations are outstanding against appropriations. Moreover when the head of a department, or mayor as chief executive, desires information in matters pertaining to economy of operation or departmental cost compared with service performed, there must be the expense and delay of special statistical investigation and reclassification of data on collateral departmental records and files.

In one department three records are kept in which expenditures, as summarized from invoices, are distributed against appropriations; in another department two sets of records are similarly kept. At the same time the same data is brought together in the finance department.

\section{Multiplicity} of processes

This information can be of little use to the department since it has no bills to pay. There is relatively small need for the department keeping records with city creditors. It being the duty of the comptroller to report to the departments each month the amount of appropriations unexpended, there would seem to be small need for a duplication of similar accounts in the departments. It would seem imperative that accounts should be kept which would show the cost of operating the several functions for which the head of the department is held responsible. But this is not done. In the street-cleaning department, the costs of operating the incinerating plant, the tug-boats, and scows are not made the subject of controlling account; in the department of Bellevue and allied hospitals, the general accounts do not show the cost of operating the 
kitchen, the cost of the laundry, the cost of housekeeping, or the cost of the several wards for each of the several hospitals operated by the board of trustees; the general accounts are designed to show what is the balance of each fund and appropriation unexpended, information which the charter requires the comptroller to furnish each month.

The present accounting system presumes that the administration is not interested in economy and efficiency, but only in knowing whether it is keeping within appropriations authorized - a character of information which both the comptroller and chamberlain are required to keep at the central office as a basis for audit and disbursement. But as a guide to the executive responsible for The complete- the economical and efficient management ness of opera- of the city affairs, and as a guide to citizen tive data and creditor, such departmental accounts can have but little value. If the head of the department of docks and ferries is asked to make a statement of the cost of carrying a passenger or a ton of freight to Staten Island, not even a statistical approximate may be gained till the data of the department has been summarized, the expenses of ferry administration, of operation, of maintenance and repairs, etc., have been brought together and lined up with the amount of business done, instead of being currently and regularly laid before the commissioner, the mayor, and taxpayer.

The man who takes up the task of devising and installing a system of accounts which within each department will give administrative results and which in the general office Need for cenwill summarize these as well as record transtral control

actions of cash and show appropriation balances unexpended - which will do this without unnecessary duplication or complexity of records 
- must have in mind the character of the administrative divisions known as departments. Leaving out of account the trust and corporate records which would be kept by such departments as are separately incorporated, such as the board of education, and taking cognizance only of departmental activities as a division of the great public corporation, the department has no assets and no liabilities, it has no cash, except such petty cash as may be collected or disbursed, it has no bonds outstanding, no interest to meet, no bills to pay. The departmental accounts are purely subsidiary, and as subsidiary accounts their chief value is to show administrative expense relations. As to the disbursements of the city against appropriations, the original vouchers and supporting invoices are returned to and become a part of the records of the comptroller's office.

Since the comptroller is required to furnish the departments with a monthly statement of appropriation balances, the only purpose of keeping accounts in departments would be as a basis for administration. But administrative cost is not usually derived from invoices. Departmental expenses are generally of two kinds, viz., salaries and supplies used. Summaries of expenses which will show economy and efficiency of management may in most cases be obtained from the time books and from requisitions on department storekeepers. The forms in which these expenses may first be obtained are in classified Departmental summaries of pay-rolls, and in classified subsidiary ac- reports of storekeepers. In organizing a counts

system of departmental expenses for corporations, which will reduce the details of accounting to a minimum, it is common to require such summaries and reports to be made in such form that when checked to time books and requisitions, and properly audited, they 
may be used as journal vouchers from which the several footings may be posted direct to the departmental expense ledger. The storekeeper must make his report to clear himself of stock, and the expenses of the department may be reported to the comptroller within a few days after the first of each month, there in turn to be entered into general controlling expense accounts of the city. A duplicate of each departmental report, and a copy of the general administrative accounts on the general books, together with a digest of administrative statistics, might also be laid before the mayor, from which the economy of operation and the efficiency of those in responsible position might be judged.

By whatever method the comptroller may undertake to reform the administrative accounts and lay the foundation for current reports and statistics necessary to intelligent direction of affairs, it will be necessary for him to Essentials of map out a system based on a common a complete classification such as will serve as a uniform system

basis for departmental reporting, and such as will lend itself to central control in the general office of municipal account. In other words it will be necessary to institute both a system of asset and liability accounts, and a general classification of income and expense accounts, in addition to the appropriation and fund accounts that are at present kept by the comptroller.

To lay the foundation for a uniform system of accounts such as is suggested by Mr. Vanderlip and by others, a system which will serve as a basis for investment judgment as well as for administrative and citizen control, and to kecp these under accounting control while order is being brought out of the chaos in the old borough records, it will be necessary for the comptroller to engage some temporary accounting device, such as for the time being 
to carry these old balances into suspense until they can be analyzed.

The work of organizing, of devising, of installing a system of administrative accounts, and of training a staff used to old ways, a staff which is leaning on a vested right to employment under civil service rules, in many cases subject to discharge only when crim-

Magnitude of the task inality or gross discourtesy and insubordination or inability can be proved, is an undertaking in which many a one who has been successful in the organization and execution of an administrative system in a business corporation might signally fail.

There are those, however, high in authority who are not wanting in faith. To advert again to the recent essay of Mr. Vanderlip: "One of the greatest opportunities to do a public service existing anywhere to-day, lies in the position of comptroller of the city of An expression of confidence

New York. The demands of that position fall but little short, in real importance, to the position of chief finance minister of the nation. In the financial world the position should be regarded as a close second in dignity and recognized responsibility to the treasury portfolio itself. There is the opportunity for the genius of a Hamilton in reforming the accounting methods and presenting to the public a true report of the business of the city. It is a fortunate thing that the position of comptroller carries with it a centralized power that makes it possible quickly to obtain effective results. It is fortunate too - and some of you may be surprised at the statement - that there are among the old employees of the comptroller's office a number of men who, for ability, loyalty, and devotion to their work, and for unselfishness of motives, may well challenge comparison with the staff of any financial institution of the city." 
The recent act placing in the office of the comptroller a statistical bureau still further adds to his power. But there are certain legal and organic difficultics to be encountered, some of which must be removed An enlargement of powers

before the best results may be insured. And above all it is to be held in mind that the comptroller is an officer independent of the mayor. The chief executive as official head of the administration, responsible for the economy and efficiency with which the business of the city is administered, must wait on the voluntary coöperation of the head of the department of finance for the installation and maintenance of departmental accounts suited to the administrative purpose.

The opportunity of the comptroller lies in his power and in a situation which offers full scope to use it. Municipal Enlarged re- accounting reform for the city of New York sponsibility of waits on the broad coöperative intelligence, comptroller and the active patriotism of the comptroller in the use of that power rather than a duty imposed by law. The fund and appropriation accounts now kept may be held by him, as by his predecessors, to meet the full measure of his responsibility. 


\section{CHAPTER $\mathrm{X}$}

The Administrative Significance of a Municipal Balance Sheet ${ }^{1}$

The literature of accountancy which deals with the use and purpose of municipal balance sheets invites greater attention in two very important particulars: (I) Those who have expressed themselves as favoring the installation of accounts which lay the foundation for a balance sheet have seemed not to perceive the administrative importance of complete and well classified statements of assets and liabilities; (2) others whose experience entitles them to be heard, have declared by most positive assertions that such a form of financial statement is meaningless - and the conclusions of these essayists, in a large measure, have gone unchallenged. In other words the literature in its present condition leaves one with the feeling that the administrative significance of the balance sheet has been but little perceived. To such an extent is this true, that the profession of accountancy has not attempted to refute the conclusion that a municipal balance sheet, in the sense in which the term is generally understood, is worse than useless.

THE CHARACTER OF ARGUMENTS USED IN CHALLENGING ITS SIGNIFICANCE

The first and principal argument of those who challenge the utility of the balance sheet may be resolved into the following deductive formula:

1 The Government Accountant, September, I908. 
That the balance sheet is an instrument designed to show the financial condition of individuals and companies engaged in gainful occupation;

That the purpose of municipals corporation is not gain;

Therefore, the balance sheet may not be used to advantage in the accounts and reports of municipalities.

Many of the assertions and assumptions made, when stated separatcly and supported by suggestive illustration, seem conclusive. The truths and half-truths contained Defects in first in statements when viewed in isolation or form of argu- arrayed in process of indirect reasoning ment make arguments seem quite plausible. But when brought to the test of careful analysis each deductive process is found to be defective. Either the one premise does not bear a logical relation to the other (and the conclusion is, therefore, a non-sequitur), or the reasoning process being logical, one or both of the premises assumed for the purposes of the argument are found to be untrue.

Accepting both of the premises assumed in the proposition stated above as being true, they bear no logical relation to each other. That is, for the purpose of this argument, the first premise ("that the balance sheet is an instrument used to show the financial condition of persons in gainful occupation") is not logically related to the second premise ("that the purpose of the municipal corporation is not gain"). In the first place, it is not assumed that the use of a balance sheet is limited to persons engaged in gainful occupation. In the second place, it is not even suggested that the balance sheet is used as an instrument for showing gain. If the first of these objections were overcome, then there would be no need for further argument, as the premise itself would state the conclusion. The second objection is quite as decisive for the reason that the assumption if made would not be true.

The balance sheet is not used to measure gain; it is 
designed to show financial condition at a particular moment. Moreover, it may be used by any person having assets or liabilites to exhibit. The balance sheet is in the nature of an instantaneous photograph of condition; by balancing resources against liabilities, the amount of the surplus or deficit at one moment may be compared with the surplus or deficit at another moment. But no information is given as to the reason for changes in the surplus or deficit. The person or corporation which shows a diminishing surplus may have had an increase of profits or vice versa. Every factor of gain and loss and every factor of distribution is left out of the analysis presented by a balance sheet. Simply the net results of all forces combined is portrayed. The second premise in the first logical form, viz., "that the purpose of the municipal corporation is not gain," therefore, carries no conclusion with respect to the use of an instrument which is not used to measure gain.

A second form of argument less frequently heard, but still one to be reckoned with, is as follows:

That the purpose of the balance sheet is to display the amount of resources, in statement form, as opposed to the amount of liabilities.

That the municipality (being an entity made up of all the people and the aggregate of all private estates and common properties within its jurisdiction) as such has no resources and liabilities.

Therefore, a municipal corporation cannot properly have a balance sheet.

This is quite as defective as the first and less ingenious. Specious character of the The logic is sound, but its second premise has no semblance of truth. Lest question second form of be raised with respect to the fairness of argument

this statement of the case, the following is quoted in haec verba from a recent address at Wash- 
ington by one of the most outspoken disciples of the school: ${ }^{1}$

"A city as such has neither capital nor revenue."

"The municipal corporation when considered as a separate entity and apart from the private estates within its territory is a penniless nonentity.'

"Any attempt, therefore, to recognize in the general statement of a city the value of common properties, is sceking to express a condition which does not exist and forces a construction that is fictitious, arbitrary, meaningless, and withal misleading."

\section{THE AFFIRMATIVE SIDE OF THE CASE}

To say that a city has no resources and liabilities does violence to every experience, every transaction, and every legal principle associated with municipal life, municipal business, or municipal law. But the fact that those who have inveighed against the making of a municipal balance sheet have failed to convince, does not raise even a presumption in favor of its use. The question must be answered: In what manner can such a statement of resources and liabilities contribute in giving an intelligent understanding of the city's business?

The municipality has been truly described as a corporation organized and maintained for the purpose of rendering to the people residing within a definitely described district, services which, by reason of density of Two classes of population, are necessary to their existence problems to be and welfare - services which could not be considered

as economically or as efficiently rendered by individuals in their private capacity as by an incorporated public institution. To perform these services

${ }^{1}$ MacInnes, Proceedings of the Second Conference on Uniform Municipal Accounting, February, 1906, page 98. 
economically and efficiently, it is necessary that the municipality have large funds provided and that it shall own and maintain extensive properties and equipment. These facts give us two classes of problems and responsibilities concerning which we should have accurate information, viz.:

I. Problems and responsibilities covering service rendered or to be rendered, and

2. Problems and responsibilities concerning the funds, properties, and equipments owned or possessed by the city for rendering such service.

THE PURPOSE OF ACCOUNTS AND REPORTS WHICH REFLECT MUNICIPAL SERVICE RENDERED

The accounts and reports of municipal services rendered, have been fairly well established along the lines determined by the character of activities undertaken; that is, by process of examination and analysis it has been found that there are five general classes of data necessary to an understanding of municipal activities, viz.:

I. Those which pertain to the corporation as such.

2. Those which have to do with activities governmental in their nature.

3. Those which relate to public education and recreation.

4. Those pertaining to public industries and investments.

5. Those associated with public or private trust relations.

To be specific: In its corporate capacity, the city must The constitu- provide for the expression of popular opinion encies to be through petition, election, initiative, referenappealed to dum, and recall. In its governing capacity it must provide for the meetings and the promulgation 
of acts of representatives; must maintain courts and central executive offices; must provide for the protection of life, health, and property, and to this end organize a police force; control the administration of health, sanitation, street cleaning, and the removal of garbage; must conduct hospitals for the sick and the injured; must carry on institutions for the insane, for the cure of social dependents, for misdemeanants and criminals, and regulate the administration of public charities. In its capacity as agent for social uplifting and individual welfare, it may provide for public schools, museums, art galleries, parks, gardens, gymnasiums, baths, playgrounds, public celebrations, music, and exhibitions. In the interest of social economy, the city may also operate and maintain enterprises for the supply of water, gas, electric lights, heat and power; may conduct transportation by street railways, subways, boats, ferries, and bridges; may give easements through tunnels and conduits, manage markets and trading places; as investor, it may rent lands and structures and provide capital for private undertakings through the purchase of shares and the making of the loans where public welfare may seem to demand such use of the communal estate for common ends. In its capacity as trustee it may hold and administer intestate estates, become responsible for the proper application of funds and the proper management of properties bequeathed to the city for specific use; it may become liable for security deposits, cash bail, pension funds, and other properties held in fiduciary capacity, for specific private or public ends.

For the intelligent direction of expenditures incurred in maintaining these several classes of activities the same information is needed as if they were administered by a private corporation. The fact that the municipality is not conducted for gain makes no difference either in form 
or classification of operative accounts. The purpose of Character of expense accounts, whether conducted by intelligence private or public corporations, is to give needed

information necessary to the determination of questions of economy and efficiency. Assuming that a particular enterprise is managed with greatest economy and efficiency, the deduction arrived at through summaries of gain and loss relate themselves to the revenue side of administration. If under such circumstances it appears that the enterprise is operated at a loss, then the only conclusions to be drawn are: (I) That the prices charged for the product or service are too low, or (2) That such part of the enterprise as is unprofitable should be discontinued, or (3) That there is some reason in institutional policy which determines that the unprofitable activities should be continued even at a loss.

The essential difference between public and private enterprise lies not in problems affecting expenditures, but in questions of price making and distribution. That is to say, the stockholder or member of a private corporation expects his returns in the form of a margin of price which will yield money dividends; the citizen or member of a municipal corporation expects his returns in cheaper or better service rendered at cost.

THE NEED FOR MUNICIPAL ACCOUNTS AND REPORTS WHICH

\section{REFLECT RESOURCES AND LIABILITIES}

The duties of administrative officers, however, do not end with economical and efficient service. Upon them also is the obligation of fidelity and exercise of judgment in the care of funds and properties, and in the protection of the institution's credit. By common law as well as by statutory enactment, a corporation assumes the same relation to property and may incur credit obligations to the 
same extent as a private person. The members of a corporation (citizens or stockholders) have no more right to trespass on the property of the "artificial person" in which they are interested or to interfere with its proprietary rights than if they had no interest whatever in it. The proprietorship of the corporation, however, is limited by its own legal incapacity. In common law it has much the same status as a minor or a married woman; it cannot transact business except through duly elected and appointed agents. By both common and statutory law, the officer is made trustee of all properties and funds belonging to the corporation or which it has in its possession. The officer, however, must act within authority, and this applies to all acts, including the incurring and paying of its debts. Notwithstanding this fact, few municipalities have attempted to hold their officers to strict account as trustees; and there are still those who stoutly advocate that it is needless to have accounts or to publish reports which reflect official responsibility as trustee.

Let us consider some of the administrative questions which arise with respect to municipal proprietorship. These are of two general classes, viz.: (I) Those which relate themselves to resources and liabilities having to do with the financing of current expense of the corporation, and (2) Those which relate themselves to the acquisition of permanent properties and equipments necessary to carry on city functions with economy and efficiency. The necessity for making this distinction lies in the difference of official responsibility attached to the various classes of resources and liabilities. The first class of resources is intended for current consumption. It is to be applied to the cost of operation and maintenance. The fiduciary relation of the administrating officer is to see that the amounts are applied with economy, and 
that the balance unused is accounted for. The second class of resources and liabilities has attached to it quite different administrative conditions. Funds raised for the acquisition of properties and equipment are not to be consumed; they are to be carefully guarded and preserved for the purchase of lands, buildings, machinery, and other apparatus intended for continuous or permanent use by the city in carrying on its current operations. When so expended the properties and equipments are to be maintained in such condition that they may not become impaired; and the cost of maintenance is to be met out of the first class of funds - i.e., set up as an operating expense. The second part of the municipal estate stands in the same relation to the city as capital to a private corporation; and the municipal officer has the same responsibility for its care and keeping as the officer of the private corporation for the protection of its capital.

ADMINISTRATIVE QUESTIONS TO BE ANSWERED WITH RESPECT TO RESOURCES AND LIABILITIES HAVING TO DO WITH EXPENSES OF OPERATION

Our next inquiry follows: What information is necessary to the proper execution of these two classes of trusts and what reports should be made to the corporate membership through the accounts? Let us ask ourselves first, what are the administrative questions to be answered with respect to resources and liabilities having to do with financing expenses of operation? The principal subjects of inquiry with respect to these are:

I. The due and demand liabilities, i.e., obligations incurred in financing the expense of operation that must be immediately met.

2. The cash on hand to meet such obligations.

3. The obligations incurred by hypothecation of revenue 
and other accounts receivable to provide the cash with which to meet due and demand liabilities.

4. The collectible revenue and other accounts receivable which have been hypothecated to secure the payment of such short-time liabilities.

5. The other obligations incurred to provide cash for current expenses, or to meet due and demand liabilities not secured by hypothecation of revenue and other accounts receivable.

6. The collectible revenues and other accounts receivable not hypothecated.

7. The surplus:

(a) Of cash over due and demand liabilities (or vice versa).

(b) Of collectible revenue and other accounts receivable hypothecated over current liabilities secured thereby.

(c) Of collectible revenue and other accounts receivable not hypothecated over current liabilities not secured.

(d) The balance of resources applicable to the payment of liabilities which may be appropriated for future expenses.

8. The amount of inventories of goods on hand and the amount of advances made which are not available for the payment of liabilities, but which may be applied as against future expenses.

9. The balance unexpended of appropriations made for future expenses and for the future purchase of supplies, etc.

Io. The present encumbrances and contract liabilities incurred against such appropriation balance unexpended.

II. The unencumbered balances of appropriations available for the expense period not yet elapsed.

All of these subjects of administrative care raise questions with respect to the current assets and current lia- 
bilities of a municipality. Each of the classes of data above suggested are absolutely necessary to an intelligent administration of the trusts imposed on the officers responsible for the funding of current operations - whether they be executive officers empowered to borrow and protect the city credit, or an appropriating and tax-levying body charged with the duty of providing the city with adequate revenues and granting the necessary authority to spend the same.

It is a fact which reflects on the American public and on its professional advisers and law-making agents more than on the municipal officer, that such accounts as have been described are not kept and such reports are not made. The individual officer who is held as trustee for the exercise of duties in these several relations seldom has the time or opportunity within a single term to work out and install the means by which he will be enabled to give such an account of his trust. It will be only when the public law sets up such a standard that we may hope for accounting methods through which these several classes of information may be accurately obtained and reported. To construct such a law is one of the problems of primary importance to charter revision commissions and to state legislatures. Having required, as a matter of legal prescription, an accounting for current resources and liabilities, periodical statements may be made which answer the questions reflecting official fidelity and which are so necessary in making an intelligent official forecast. The same enactment should require operative statements based on accounts of expenses incurred and revenues accrued so that the officer may be held to his responsibility for economy and efficiency of service during his administration. In other words, the current surplus or deficit accounts on the balance sheet should find complete 
analysis in the details of municipal operation accounts, and in gain and loss accounts.

QUESTIONS TO BE ANSIVERED WITH RESPECT TO THE FUNDS PROVIDED FOR ACQUISITION OF PUBLIC PROPERTIES AND EQUIPMENT

Quite as well defined are the classes of administrative questions to be answered with respect to the funds provided for the acquisition of permanent properties and equipment, with respect to the liabilities incurred in raising such funds, with respect to the sinking fund or other contracts made for the payment of these obligations, with respect to the investments of the city and to the properties and equipment to be maintained for continuous or permanent use. Again following the line of official responsibility, accurate and detailed current information should at all times be available for answering such questions as these:

I. What amount of indebtedness, incurred for municipal capital and equipment, is still outstanding?

2. What are the contracts for maturing these obligations; what the sinking fund provisions made for meeting them when due; are these sinking fund contracts being fulfilled?

3. What are the balances unexpended of funds obtained for construction or investment purposes; are these balances intact or have they been diverted to other uses; what uncompleted contracts or other encumbrances are there against these balances; what is the condition of the property under construction for which these funds have been provided?

4. What has been the cost of properties and equipment provided for purely governmental functions; are these properties currently maintained, and if not, how much have they been allowed to depreciate? 
5. What amount of the properties and equipment for purely governmental purposes has been obtained with funds obtained by borrowing on municipal credit; what amount is represented by appropriations from revenue either directly, through sinking fund instalments, or by payment of the debt incurred for these purposes?

6. What has been the cost of properties and equipment provided for education and recreation; are these properties being currently maintained, and if not, how much have they been allowed to depreciate?

7. What amount of the properties and equipment for education and recreation has been obtained with funds obtained by borrowing on municipal credit; what amount is represented by appropriations from revenue either directly, through sinking fund instalments, or by payment of the debt incurred for this purpose?

8. What classes of municipal enterprises are owned by the city; what has been the cost of properties and equipment of each class; is each class of properties being properly maintained, or if not, how much has each class of properties and equipment been permitted to depreciate?

9. What amount of each class of these properties and equipment has been purchased with funds obtained by borrowing on municipal credit; what amount of each class is represented by appropriations from revenues either directly, through sinking fund instalments, or by payment of the debt incurred for these purposes?

Io. What investment has the city made in stocks, bonds, real estate, or other properties or rights not included in the other classes of accounts enumerated; how were these investments obtained; how have they been administered?

When considering the accounts of municipal industries, few accountants have had the temerity to deny that "capital accounts" have a distinct administrative ad- 
vantage: (I) by keeping before the officer the properties to be maintained; (2) by giving a proper basis for the actuarial estimates of depreciation to be overcome through the aggregate of provisions made for maintenance; (3) by providing through accurate cost accounts for the information necessary to the making of an intelligent rate of charge to the public for services rendered. None of these problems may be properly dealt with, without an adequate system of capital accounts maintained in conjunction with an equally adequate system of operative accounts.

Relatively few accountants, however, have perceived the administrative advantage of maintaining accounts which show what we may call the net present worth of the properties and equipment used for purposes of eduThe analogy cation and recreation, and for purposes of of private ac- purely governmental functions. Pavements counting

and sewers have been frequently cited as forms of improvements concerning which no capital accounts are to be carried. While this is to be admitted if considered in relation to the public debt, from an administrative point of view the sewer has a present worth which should be represented in accounts. Administratively, the moncy paid for paving a street with asphalt, which will last ten years, is to be considered as belonging to the same category as money paid in advance for the insurance of a building for ten years. In the latter case, no question is raised with respect to both the financial and administrative advantage of showing each year's insurance charge separately as an expense of that year and carrying the balance of the "advance" as "prepaid insurance." And any institution which carries such an account will show the amount of "advances" for prepaid insurance, prepaid rents, etc., on its balance sheet. 
For the same reason the actuarial depreciation of the pavement should be charged to the current year's expense, while the balance, or the total cost of paving, less depreciation, should remain on the books and should appear in The protection the capital balance sheet. The adminisof municipal trative advantage of such an account is properties

not difficult to see. It keeps constantly before the officer a matter which leads to intelligent inquiry. What pavement does this account in the general statement represent? What are the details supporting it? What streets will need repaving this year; what the next; what the next; etc.? What current provisions are being made to meet the depreciation of the streets? Will a large number of streets require repaving within a single year? If so, then what year and what provisions are being made to equalize the burden?

All of the permanent properties and equipment of a city may be accounted for on the same theory. If the amount of the cost of such improvements is considered as the actuarial depreciation of subsequent years, then there is the same reason for carrying the cost of a school building into a balance sheet as there is for carrying the cost of prepaid insurance or prepaid rents. The account for permanent improvements, however, would appear in the capital balance sheet, instead of being The controlling considered a current asset - a conclusion purpose of the made necessary by reason of the character balance sheet of the administrative questions to be answered through the two classes of accounts. The controlling purpose of the current balance sheet is to display the several forms of assets available for meeting current liabilities and current expenses. The controlling purpose of the capital balance sheet is to represent the capitalized cost of permanent improvement and equipment and the 
funds provided for such use. Items affecting the debt limit may be taken from both, but should be set up as a statistical summary from the accounts, since the debt limit is purely arbitrary and may bear little or no relation to the administrative accounts.

With relation to the current charge to be made for the purpose of protecting the capital of a city from becoming impaired, we have the same problem before us as is presented by any corporate enterprise, viz., that of providing for the actuarial depreciation of a building which has been erected, in order that the corporation may have either a building of similar kind and quality, or a fund sufficient to replace such a building at the end of a given actuarial period. Having determined on the amount of such annual charge to expenses, this amount should be set up as a "reserve for depreciation" and the cost of the repairs against the reserve. Each year it should be the aim of the city and of the officers holding positions of trust and responsible for the protection and maintenance of its properties to expend an amount for repairs which will maintain its properties and, as a whole, protect them from depreciation. In case such repairs are not made, then the account should show by what amount the city has permitted its properties to depreciate and to what extent it has failed to charge the current year with the amount which is necessary to equitably distribute expenses of maintenance over a period of years. Without such provision, either the city is suffering a loss without knowing it, is diverting its funds to uses to which they should not be put, or is piling up the expenses of current years to be met out of the revenues of years to come.

To assume that such funds when accurately presented through accounts must necessarily be "fictitious" is to 
indict the integrity of every resource and liability account other than cash kept by a private corporation, and the intelligence of every administrative judgment based thereon. To state that the capital balance sheet when applied to Conclusion municipal enterprises is meaningless and misleading, reflects not on the methods used for obtaining information as a basis for administrative judgment, but condemns the one who indicts it. The conclusion that the categories used in capital balance sheets when applied to municipalities are misleading, and, therefore, not to be used, is premised on an assumption that no information is needed other than a statement of receipts and disbursements with its residual balance of cash. This assumption fails to consider every question of economy, every question of efficiency, and every question of trusteeship other than that relating to the custodianship of money. Another defect is also found in this kind of reasoning, namely, that no financial statement is to be considered of importance, except one by means of which may be ascertained the amount of resources immediately available for the payment of debt. This, again, is based on erroneous assumption, viz., that the payment of debt is the only administrative responsibility which a municipal officer has to meet or in which the citizen is interested. That the administrative significance of the balance sheet has not been considered by those who deny its usefulness, cannot be more conclusively shown than by the analysis of the accounts and the financial statements of municipalities to which such a method has not been applied. In the city of New York, for example, its officers hold in trust properties and equipment which have cost not less than $\$ 1,000,000,000$, without an account being carried on the books to represent the present cost of any property, or even to preserve a list of the real estate, buildings, and 
equipment which the city owns; as a result of which it has more than once paid for properties to which it has already acquired a title. Each year these officers purchase and have delivered to warehouses or municipal stores not less than $\$ 20,000,000$ worth of supplies and material for fully one-half of which no store accounts are kept, and such as are kept are nothing more than memoranda, not being under accounting control. Constructions and betterments are written off as soon as completed and no accounting control has been maintained over departmental expenses. Liabilities, amounting to millions of dollars, are not kept on the books, either of a department or in its central office. Each year most elaborate statements of receipts and disbursements are prepared and published without shedding any light whatever on the many problems relating to municipal activities, which should be reflected in the accounts and published reports. Moreover, these reports are usually so late in their appearance as not to be of aid even as information collateral for the making of the budget. The administrative significance of accounting and reporting has been in a large measure lost sight of, and ninety-five per cent of all our American municipalities are in the same dilemma. It is therefore urged that accounts through which information may come to the public in balance sheet form is one of the most urgent needs of modern municipal affairs. 


\section{CHAPTER XI}

The Administrative Importance of Distinguishing BETWEeN REVENuES AND EXPENSES AND ReCEIPTS and Disbursements in Municipal Accounting ${ }^{1}$

THE degree of elaboration here given to the two sets of ideas - revenues and expenses on the one hand and receipts and disbursements on the other - would seem without warrant before a Convention of Accountants were it not for the fact that the general practice in municipalities of the United States is to confuse them. Few American cities have a complete system of accounts. They have various books of original entry and departmental records; prominent among these are the accounts of the municipal treasury. The "cash account" is classified and subdivided and differentiated by bureaus and by departments and stated with a degree of elaboration and complexity that has led many municipal officers and citizens to think that in this they have a comprehensive system. In most cases, it may be said, memoranda are kept of other financial transactions which might have been classified and correlated and reduced to a complete system of accounts, but they are not. Many cities have complete data in the form of books of original entry; these again might have been used as subsidiary and supporting records to a complete system of controlled accounts.

Few of our municipal accounting officers have even

1 Paper read before the Congress of Accountants held at St. Louis, Mo., September 26, 1904 . 
considered the need for accounts of expenses and revenues and of keeping records which will exhibit any relation of service rendered to expense incurred; nor have they endeavored to bring into alignment cost of service with current revenue provisions made for meeting expenses. Responsible officers are unable to obtain these results for their own guidance. The Burcau of the Census in its attempt to collect the municipal financial data with respect to the assets and liabilities and revenues and expenses of municipalities has not been able to obtain complete information from the books on any subject other than cash receipts and cash disbursements. The published reports of cities contain little else than exhibits of the flow of cash. Citizens and taxpayers are not able to learn from the published reports or from the accounting officers the facts necessary to judge as to the efficiency of administration in any of its departments.

\section{ELEMENTS ESSENTIAL TO A COMPLETE SYSTEM OF MUNICIPAL ACCOUNTS}

A system of municipal accounts is a method or means whereby all of the financial transactions and all of the data pertaining to the financial management of the city are (I) collected, (2) classified, and (3) finally coördinated around problems of municipal administration. The books and records are simply instruments used for accomplishing the ends above indicated. These three essentials of a system must, therefore, be represented in the books and in the records kept.

The books, vouchers, and other records of original All data must entry are kept for the purpose of collecting be collected financial data. To be complete they must contain evidence of all transactions, whether of cash or of operative relations. But for this purpose no 
classification or final statement of account is necessary. In a small business such data are usually kept in a day book in chronological order, because of the greater convenience in making current entries. So far as the purpose of the record is concerned, the only need for order or for having any system about these data is to know that all transactions have been recorded, and to aid the proprietor or management in locating the evidence of a transaction when such evidence is desired.

In small concerns separate books or records of classification are kept. These are known as journals. To "journalize" means to classify. Usually, in large enterprises and in municipalities having complete systems, for reasons of economy the books of original entry or those used to collect the financial data are themselves classified, thus forcing a classification of the data recorded at the time of making the original entry. In whatever form they are found, however, books of original entry Each transac- and of classification are not books of final tion must be account. They simply record isolated facts properly clas- and register the judgment of the auditor or sified

other accounting authority as to the account to which a particular isolated transaction belongs. These books and records for the collection and classification of data are necessary to a complete system of accounts, but they must be regarded as purely subsidiary and supporting documents.

The accounts themselves are found in the third class of

All facts must be coördinated around problems of administration books or records indicated, viz., books of final coördination. In municipalities they are of two kinds: (I) special and departmental ledgers, and (2) general ledgers. Completeness in the general ledgers (the controlling accounts themselves) is usually lacking in American munici- 
palities. A city may have the vouchers, the memoranda and other forms of original entry of every transaction and financial relation, but these are left incomplete both in their classification and in their final coördination. In many instances, even the records of vouchers and the books of original entry of transactions are also defective. The only transactions pertaining to which there has been a uniform demand for completeness in municipal accounting are those which have to do with the municipal treasury - the "cash" accounts of a city.

ESSENTIAL DIFFERENCE IN THE NATURE OF EXPENSES AND REVENUES AS DISTINGUISHED FROM RECEIPTS AND DISBURSEMENTS

Corporate limitations and necessities on the one hand and corporate purposes on the other determine the classification of ${ }^{\prime}$ accounts. Corporate limitations and necessities inhere in the fact that a city is impotent to act or Two general render service without physical equipment classes of ac- adapted to its ends. Its corporate purcounts poses are principally in the public service rendered or to be rendered. Conformably to these controlling needs and conditions, administrative problems are of two general classes, and for this reason the accounts of a municipality (in any complete system) must be grouped around two general categories, viz.: (I) those of proprietorship and (2) those pertaining to service or operation.

Accounts of proprietorship relate to ownership (or to assets acquired) and to financial obligations (or to liabilities incurred) by the city acting in its proprietary or The balance- corporate capacity. Cash is an asset. It sheet item reflects relations of proprietorship only. "cash" Receipts and disbursements indicate the volume and direction of the flow of cash. Accounts of 
service rendered pertain to cost of service and to the provisions made for meeting this cost. Expenses and revenues are the terms used to characterize the two classes of controlling accounts which have reference to the two principal aspects of municipal service, as distinguished from controlling accounts representing relations of proprietorship - or assets and liabilities. Accounts of receipts and disbursements have no reference to service rendered. They pertain to the other general category referred to as proprietary accounts. Receipts and disbursements are the names given to the debit and credit sides of an asset account. By a process of subtraction of "disbursements" from "receipts" the "balance" of current funds on hand at a given moment is shown.

In accounts "revenues" are not "cash." The revenue account records the total accruals from tax levies, fines, fees, licenses, etc., during the period for which it is kept. A statement of revenues is a record of increments of wealth to be used for the current support of government; these increments are usually in the form of rights to receive money, the payment of which, The operation however, may be deferred for months and
account even for years; receipts have reference to cash only. Revenues do not include accruals that are not intended for current support of government, such as assets obtained on account of the sale of bonds, temporary loans, or other credit contracts. Receipts, on the other hand, comprehend all cash received from whatever source. Revenues do not include transactions in the nature of sales of permanent properties and equipment; receipts include the amount of cash realized on every class of sale.

Revenues have to do with all transactions which are carried on for the purpose of obtaining a financial increase 
as a means of carrying on the operations of the municipality and of maintaining its physical equipment. The revenue account is not made up from the same original entries or vouchers as is the cash account. Tax revenues are drawn from the roll of tax levy; license revenues are made up from the license registers; revenues from fees are taken from dockets and fee books; revenues from municipal industries are drawn from the various industrial income accounts. Accounts of revenue are made up from

\section{Different} sources of revenue accounts and cash receipts records kept of increments of wealth (usually in the form of rights to receive) for current administrative purposes. The accounts of cash receipts are drawn from records kept of cash actually taken in; the fact that any amount of money was received on account of revenue accruals of previous years, or that the transaction pertained to the issue of bonds, makes it no less a cash receipt. The accounts of cash receipts are drawn from the records and statements made to the treasurer of licenses and fees paid, etc., and in municipal industries from cash books; or if the treasurer of the municipality is custodian of these funds, from statements of cash returned to him. For the purpose of determining revenues accrued no inquiry is made as to the amount of cash received on account of these accruals. For the purpose of determining receipts no thought may be had of revenue accruals. The two statements are absolutely separate and distinct categories of business, of accounts, and of finance.

The same general distinction may be made between accounts of expense and accounts of disbursement. A statement of expenses shows the total amount of cost incurred in an enterprise, public or private, on account of current operations and maintenance. This statement is drawn from records of cost and has no reference whatever 
to payments in cash. "Cost" and "Cash paid" have very different meanings. The entire expense or cost may have been incurred for a period stated without a dollar having been paid out or disbursed. Again, during the same period, there may have been disbursements amounting to many times the expenses incurred. In a banking Accounting business, for example, a statement of exsources of ex- penses incurred for a given year would penses and dis- include summaries of salaries and wages, bursements

rents, insurance, supplies and stationery, taxes, interest on account, etc. For a given institution this may amount to ten thousand dollars. During the same period the same institution may have received and disbursed several hundred thousand dollars. A city having current expenses amounting to a half million dollars per annum may, through various refunding processes, disburse a million and a half. A statement of revenues and expenses is a summary made up from all the accounts of a municipality which have to do with cost of operation and with the provisions made for meeting this cost. Such a statement and summary is based on vouchers and reports drawn from every department and bureau. Statements of receipts and disbursements, on the other hand, pertain to the municipal treasury alone. They are the summaries of transactions of the "receiving" and "paying" tellers of the municipality. The cash balance or "Cash on hand" is one of the items of municipal assets. The balance obtained from current revenue and expense accounts shows the revenue surplus or deficiency for the fiscal period.

DIFFERENCE IN ADMINISTRATIVE PURPOSES OF THE TWO CLASSES OF ACCOUNTS

Another line of demarkation is found in the different administrative purposes of these two classes of accounts. 
The purpose of assembling the financial data of a municipal undertaking around the two categories expense and revenue is to enable those interested in the public service to reach conclusions with respect to economy and efficiency of administration, and the relation of cost to provisions made for meeting it. In these the taxpayer is financially interested as the contributor of funds for the support of current municipal activity; he would have

Purpose of expense and revenue accounts economy as a means of reducing his own personal expenses; the citizen is interested in economy as the one for whose benefit the corporation was organized and is maintained; for him the greater the economy the greater the amount of service available. The officer of the public corporation is also interested in well-authenticated statements of revenues and expenses as a means of protection and as a guide to official judgment; such an assembling of data is necessary to the proper guidance of the affairs with which he is interested and for the direction of officers under him. A detailed and comprehensive statement of expenses is essential to a proper appreciation of cost to service rendered. A comparative statement of expenses and revenues serves two purposes of administrative economy: (I) Such an exhibit is necessary to determine whether adequate provision has been made to cover the costs of operation and maintenance in the past; and (2) a comparative statement of past expenses and revenues is the only safe guide to budgetary estimates and appropriations for the future.

Accounts of receipts and disbursements, on the other hand, serve quite a different administrative purpose. As before suggested, statements of receipts and disbursements are statements pertaining to the cash account. The cash account does not and cannot of itself represent 
any feature of administrative economy. The one side of a cash account shows the cash taken in, and the other side shows cash paid out. Money balance is an asset. Money taken in is not a revenue. Money paid out is Purpose of not an expense. Money may be derived accounts of from "taxes receivable," from "accounts receipts and receivable," from "judgments receivable," disbursements from "sales of bonds" or other "credit contracts payable," or from the sale of buildings and equipment. Receipts and payments have relation to asset and liability accounts only. In making provision to meet current liabilities appropriations are made, and these appropriations may have separate accounts in the treasury department, or may be separately set up on "appropriation ledgers." But for purposes of final statements of asset and liability accounting, it is of administrative importance to know the amount of receipts and disbursements with respect to each fund, the purpose for which the funds have been expended, and the balance on hand.

It is of importance to the taxpayer, the citizen, and the administrative officer, also, to know that those into whose hands the properties of the city are placed have been faithful to their trust. Aside from the fact that a department record is an integral part of a general system of accounts, and for this reason is necessary to an intelligent controlling summary of assets and liabilities, the officer

\section{Purpose of} trust accounts entrusted with funds must be held to an account for his stewardship. One of the most important of departmental records reflecting relations of fidelity is that of the municipal treasury. Besides an asset statement of cash-balance, therefore, accounts of receipts and disbursements are important as a means of insuring fidelity of service and protecting the corporation against losses due to peculation and 
misappropriation. These two classes of administrative purposes, however, pertaining to accounts of receipts and disbursements, are quite separate and distinct from the purposes governing accounts of expenses and revenues.

THE REASON WHY THE "CASH-BOOK" ACCOUNTS ARE THE

\section{PRINCIPAL ONES KEPT IN AMERICAN MUNICIPALITIES}

The fact that the cash-book accounts are the principal ones kept by American cities is not without reason. The cash-book is the first record developed in the evolution of accounting methods. Until comparatively recent date, "tallies" were used by British government. In primitive enterprises, one not so large that every detail and transaction may not be performed by the proprietor himself, Cash the first there may be an entire absence of record. asset to be Even when memoranda are kept no attempt guarded

is made to classify them and reduce them to a form of final statement. The first necessity for complete records comes with the introduction of employees into the business, charged with the custodianship of property which may readily be misappropriated.

The most easily disposable property is cash. The primitive cash account was used as a means of detecting infidelity among servants or employees. This at best could not be more than a special record, since it leaves out of consideration all transactions not accompanied by cash. To the cash-book as a beginning were added other books of asset and liability account. Based on the principle of fidelity of servants and of protection to the proprieSingle entry the first accounting method tor, there was finally developed a complete system of asset and liability accounts. In the evolution of business the first complete accounting system was the "singleentry" system, which gave a complete record of financial 
transactions and grouped them around categories of proprietorship and relations of fidelity.

The single-entry system, however, was not found well adapted to the modern and more complex business development. From the primitive simplicity of a one-man tradesman's establishment to the complexity of modern corporate organization, in which an army of employees is brought under coöperative management, with an estate worth millions or even billions of dollars, there has been an evolution in accounting methods which not only would protect the proprietor against infidelity of his many servants and employees, but would also give to the one in control such information as will enable him intelligently to direct the enterprise.

The proprietor and the management must have a system that would insure efficiency as well. With depart-

Complete double entry

mental organization, with the division of service into cohorts and battalions, each cohort working under its captain, who is responsible to the head of a department, the heads of departments in turn being accountable to a chief executive - under such conditions and with such an organization, central administration requires that all of the data pertaining to operation be assembled, classified, and finally stated in accounts such as would lay the foundation for the exercise of mature administrative discretion. Without a method of obtaining complete information concerning every question to be administered on, which would produce this information accurately and promptly, intelligent judgment could not be exercised. A second and more advanced system of accounts was developed (known as the "double-entry" system), in which the aim was not only to collect all of the financial data of a business and to assemble them around the "single" relation of proprietor- 
ship, but to distribute these in "double" relation, viz., (I) to accounts of assets and liabilities, and (2) to categories of income and expense, from which might be drawn summaries of profit and loss, financial distribution and surplus. And in further elaboration of which accurate and current cost data might be made available in every service and activity.

Even in private business this development has been comparatively recent, and in America accounting ideals remained undeveloped long after they had risen to a basis of scientific classification abroad. As has been pointed out before, this was largely due to the lateness of our national development. The fact that the cash-book is still the central feature in the accounts of American Recent devel- cities can also be explained by their comopment of ad- paratively recent origin and by their failure ministrative to appreciate the necessity of a well-organaccounts

ized system of double-entry accounts, not only as a means of insuring official fidelity, but also for purposes of municipal control and the attainment of higher administrative efficiency. The accounts of municipalities (even of many of our largest cities) are primitive. They are of the kind that would be found in a business amounting to a few thousand dollars per year, in which the cash-book is the principal record kept.

It has been said that the smaller cities need nothing more than a statement of receipts and disbursements. This may be admitted on the same principle that a small merchant needs nothing more than a cash-book or that a peanut vender needs no books at all. If the business of a town or village is so small that all of the administrative facts and relations may be held in mind both by officers and citizens, and the properties and liabilities are not important, then an accounting for "cash" may serve the 
need. The need for books of account is a relative one. The whole question is to determine at what period in the development of municipal enterprises a complete system (either "single" or "double" entry) is necessary to the intelligent direction of affairs.

"The business of this city is on a cash basis; we therefore need no accounts other than those of cash." This is the answer usually given to a criticism that a particular municipality, large or small, has no accounts of revenue accrued and expenses incurred. While the answer is offered in good faith, and the one offering it may be strong in the belief, yet neither the premise nor the conclusion is true of an American city, and it may be doubted if it Cities on a "cash basis" is true of any city. What is really meant is this: The city has borrowed money, by hypothecation of its revenues or otherwise, to meet current obligations. It is paying one class of creditors by means of cash obtained on credit from another class of creditors. There is not a city in the country whose revenue collections for a given year are not from six months to two years (in some cases even three or five years) behind the expenses incurred for the same period. In ordinary affairs business done by means of current borrowing is not considered a "strictly cash business." It is this situation that makes so difficult even a statistical approximation of current revenues and expenses from accounts reflecting treasury transactions.

But even assuming that a city were in such circumstances that it were not necessary to borrow, assuming that its revenues were all paid on the very day that they are made payable, still the administrative need for operative accounts (showing relations of cost to provision made for meeting cost) would be just as necessary to efficient government. There is no form of enterprise whose rev- 
enues are more nearly on a cash basis than a railroad company. And there is no organization whose administrative officer watches more closely accounts of revenues and expenses. Those railroads whose accounts do not give this information, or whose administration does not use the data so collected and classified as a basis for judgment, have either long since passed into history or are fast approaching that abyss which awaits the financial suicide. The operative head of a large transportation Cash accounts company seldom looks at the cash statedo not give ment of receipts and disbursements. These operative re- are for the consideration of the financial sults

department. The president of a railroad knows that administrative efficiency and administrative success must be the results of judgments made with respect to cost of operation and financial return for service performed. If these judgments be such as to leave a small margin of profit, or even if only that operative cost be met, the financial head of the organization will be able to provide the cash. Whether the cash is provided out of current revenue collections, or from bills and accounts receivable, accrued from past operations, or from temporary loans, he has little concern, except in so far as these financial transactions may increase expenses and make his operative problem the more difficult.

When the administrative heads of our municipal corporations may have accurate current accounts of revenues and expenses, and when their judgments may be made with respect to these, and they in turn shall be judged according to the efficiency of their own administration measured by standards of cost and service rendered, we may look for the dawn of a new day. In the business world failure to adopt proper methods is marked by financial failure; as a result the administrative methods 
which survive are those which are efficient - those which are adapted to success. With a city, however, the fact that it cannot be permitted to go out of business so long as the community remains, makes the question of determin-

Sound judgment requires operative accounts

ing just when a modern method of accounting shall be applied wait on the exercise of political rather than business discretion. Municipal administrative methods cannot be improved through the operation of that principle of evolution known as the "survival of the fittest," except as this principle is applied to parties in power. Reform must come through a perception of municipal needs and through a force in the form of popular demand that will break through the lethargy of custom and compel an abandonment of primitive business methods.

HOW A CLASSIFIED STATEMENT OF CASH RECEIPTS AND DISBURSEMENTS MAY CONTRIBUTE TO IMPROVED METHODS OF ACCOUNTING

That any change is beneficial which will give to the administration and to the people a better understanding of municipal affairs will not be gainsaid. In the absence of a complete system of accounts the transactions of the treasury may be so classified that by process of statistical compilation and mathematical reasoning a fair approximation as to results may be reached. It is for the reason that some light is better than none, that a published report of classified receipts and disbursements is to be

Incomplete cash data better than none welcomed. Not that the cash books can ever be made into a complete system of accounts - nor that statistics drawn from cash books can take their place. Not that a report of cash receipts and cash disbursements can ever give the administration the best basis for intelligent con- 
trol, the details of whose business are not entirely under the direct scrutiny of its chief executive; nor that a statement made of cash receipts and cash disbursements can ever give to the public the information necessary to a proper estimate of the ability and economy of their agents. But whenever resort is had to a rearrangement of the cash account as a means of supplying statistical information of this kind, such action on the part of officers is to be considered as an attempt to get at results which before were unattainable, and to deduce from such accounts as are kept conclusions which are not found in the "footings" - viz., to get at revenues and expenses. Such an effort, while it may require a process of mathematical computation to enable those in control to get a better basis for administrative consideration, is in itself an admission of a need for a complete double-entry system of accounts.

Attempt has been made to justify the classification of receipts and disbursements around categories of revenues and expenses on another ground, viz., that the city's accounting officers must be led on step by step - that they cannot appreciate nor operate a complete system. While the introduction of a classification of receipts and disbursements in lieu of accounts of revenues and expenses may be justified as an immediate step demonstrating the limitations of such a practice, the relation which this bears to the evolution of accounting systems is not correctly perceived. Any attempt to restate the cash-book to give results desired as a beginning in the installation of a complete double-entry system of accounting starts the Mistaken idea of progress evolution at the wrong place. From the cash-book a system of accounts can never be developed without abandoning the very methods which are here applied as a first step in the. 
evolution, viz., the classification of receipts and disbursements around subjects of revenue and expense. As soon as accounts of revenue and expense are set up, there is no further use for the statistical method which before was applied to the cash account. After the introduction of a complete system of double-entry accounting the only cash accounts that need be kept in the general ledgers and the only statistical statements of cash which need be made are those which relate to funds and appropriations.

The evolution which comes from, and which is to follow, a classified cash-book must be regarded as a development in the perception of a need for a complete system of accounts - rather than a step in the direction of its installation. When this perception has grown to a demand that such a system be installed, the previously reconstructed cash accounts must be thrown out as a temporary Evidence of encumbrance on the foundation to be used perception of a for the permanent structure. To restate need

the conclusion: In the absence of systems of account from which information may be had as to revenues, expenses, assets, liabilities, and current surplus and deficit, the advantage of having the best information obtainable from books in use makes it desirable that the accounts kept be reduced to a form of statement which will admit of mathematical deductions as a means of approximating the conclusions desired. In such event, however, the report of a city may more properly be prepared by a statistician. The work of preparing such a report is not accounting, the method is not governed by accounting principles, and the report itself is not a publication of accounting results. But in doing this statistical work there is a distinct administrative advantage by adopting a form of statistical statement which will permit one city to compare administrative results with those of another. 
Recognizing the indisposition on the part of municipalities to introduce complete systems of account, efforts have been made (notably by the National Municipal League and by the Bureau of the Census), to bring over the statistical statements and reports of receipts and disbursements to a form which would admit of the use of the cash-book accounts (actually kept by cities) to the highest statistical administrative advantage. The statistical method of these two organizations is necessarily

An aid to statistics one which would give a uniform basis for comparison. The problems which each have had in mind have been primarily those of administrative economy. For this statistical purpose each has carefully worked out the categories of revenues and expenses. In applying these categories of revenues and expenses to the cash-book as a basis for their statement and report of receipts and disbursements, they have recognized that the method adopted is an expedient calling attention to the need which is not supplied in the accounts, and looking forward to a time when a system of municipal accounts may be installed which will furnish an accurate statement of revenues and expenses without the use of this statistical expedient. For the work of the League and of the Bureau of the Census nothing but the highest commendation is to be given. But the fact that they have employed a useful statistical expedient, in the absence of proper systems of account, is no reason why accountants should employ the same method in devising accounts intended to remove the necessity for use of this statistical method. The accounts should close with a statement of revenues and expenses direct, and give to the statistician an accurate summary of transactions representing administrative economy without resort to mathematical approximations drawn from the transactions of the treasury. 


\section{IMPORTANCE OF THE DISTINCTION}

For the last two decades American cities have been struggling with the problem of administration, and in their struggle have been brought face to face with the need for a change in political organization which will remove the various checks and balances heretofore imposed as a means of insuring official honesty. It is found that integrity may be vouchsafed through devices by which responsibility may be fixed without impairing administrative efficiency. The demand of the time is for increased efficiency, and as a means to this end the tendency is to centralize executive control in the mayor. With the centralization of administrative responsibility, however, efficiency requires that a complete record of transactions be placed in the hands of the mayor. As a means of securing both economy and fidelity, for the enlightenment of officers and for the satisfaction of citizens and taxpayers, a complete system of accounts is demanded which shall be more than a record of receipts and disbursements of the treasury together with such ancillary data as may be collected by means of statistical schedules and special reports. To devise systems of municipal accounts, and to install these for the use of officers of administration and for the instruction of citizens, is the Essential to work of the public accountant. This work administrative cannot successfully be attempted, however, efficiency

by ignoring the fundamental distinction between revenues and expenses on the one hand and receipts and disbursements on the other. Such a confusion bespeaks an utter disregard for the purposes of accounting, for the problems of administration around which accounts are to be classified and coördinated, and for those well-established principles of finance and admin- 
174 REVENUE AND EXPENSE ACCOUNTS

istration with which accounting results and financial reports must be harmonized. It is in this situation that the importance of such a distinction is found and warrant for the discussion of elementary principles at a National Congress of Public Accountants. 


\section{CHAPTER XII}

The Nomenclature and Phraseology of Municipal Administration and Accounts ${ }^{1}$

So far as is reported, there is only one occasion when an address on nomenclature and phraseology would have been an attractive subject for popular presentation that was at the building of the Tower of Babel. Times have changed. With us it is not a corrupt and wicked generation that is confronted by failure to make themselves understood. The modern municipal grafter thrives best in silence and in darkness. He desires no language that may leaven popular ignorance as to his doings. Not the civil servants who have profited by their own insolence, but political masters with tongues confused, are seeking common emblems of speech.

Words are symbols - they are artificial signs expressing ideas. To convey meaning they must be commonly understood; but a common understanding presumes common ideas which may be similarly expressed in words. Common ideas, in turn, require that subjects of thought shall be analyzed; and that objects of thought shall be commonly classified. Finally, every classification which takes hold on the mind of man must proceed from some common, intelligent purpose. For principles governing common words, therefore, we must look to common ideas, common analysis, common classification, and, back of

${ }^{1}$ Paper read before the Ninth Annual Conference of the National Municipal League held at New York, April 25-28, 1905. 
all, a common end or human desire. An example: The word "dog" will convey no idea, unless the one using the symbol and the ones to whom it is addressed have the same mental picture. But the image aroused by the symbol d-o-g proceeds from a classification of animals dependent on a common analysis by which the domesticated canine is distinguished from his associates, cats and fleas. This analysis and classification proceeds from a common, human interest which requires that living and creeping things be so distinguished as to permit us to think about them in a rational manner. We say the dog whines, and in using the symbol "whines" we presume that all are able to distinguish the class or kind of vocal disturbance common to hungry dogs.

Science is a codification of exactly determined commonsense, i.e., common observation of facts, common analysis

Principles

determining scientific nomenclature and common classification pertaining to a single subject of human interest. The end of science is to establish conclusions that may be accepted without question for purposes of research or instruction. To express these scientific observations, analysis and classification must be accurate, and we must have words that are commonly understood and that leave no room for doubt as to the object or subject or class intended. Since science is a body of exact knowledgc, it must have an exact nomenclature and phraseology. Without a common language, exact knowledge would be confined to the observations, to the analysis and to the classification which each individual makes for himself. Without exact symbols by which we may convey to others the results of our investigation and intellectual labors, the human race could never rise above the plane of the Bushman or the digger Indian. Intellectual progress may be said to proceed in almost 
direct and exact ratio to the precision with which ideas and intellectual results may be conveyed through symbols. As each relation becomes established, this intelligence may be exactly expressed and conveyed to others, who, using this as an accepted premise for further thought, or as a working hypothesis for further investigation, move on in the intellectual procession, each establishing a new monument, or leaving a new marker to guide others in the exact survey of the field.

All of this is commonplace in the so-called exact sciences. What about politics and economics? In neither of these fields of investigation may there be said to be a wellestablished method of analysis, a commonly accepted classification, or an incontrovertible conclusion. What is the reason? There is among political and economic investigators a total lack of system whereby a common count can be taken or a consensus of judgment may be obtained. Private business, in some respects, has been fortunate; for purposes of investigation and instruction to those in control, private business has reduced itself more nearly to scientific standards than has any department of economics. In this, however, the whole effort of the persons obtaining exact knowledge has been to preserve secrecy, both as to methods and as to results, so that the one possessing superior information might turn it to his own advantage, even against his associates. In a modern corporation, for example, the best of methods may be employed and accurate information may be brought together on every subject and detail that is of interest to those in control. In reporting this information only so much is given out as will satisfy the most urgent demands of stockholders - the rest is not told in order that the public may be kept in ignorance. More commonly the stockholders themselves are compelled 
to rely implicitly on the fidelity of their agents, they themselves being given practically no information concerning any essential feature of the business. Too often the result is that the officer of the corporation having "inside" information is turning this to his personal account, while the stockholder and other "outsiders" are left in the blind faith that all is well.

The public administrator has not the seal of secrecy placed on his lips. Every opportunity may be given to him who would know the facts, provided he collects this information for himself. Yet so complicated and so numerous are the transactions of a modern municipality that no one person (even though he give his entire time), is able to analyze, to classify, and to summarize them. To act wisely, the head of a municipal department must have every detail of service for which he is responsible and every transaction constantly before him; to do this may require accurate detailed daily reports from his foreman and division superintendents. As a means of making these detailed reports useful, a staff of clerks must be employed in organizing and digesting the information as received. By some such system the head of a department may intelligently direct the affairs of his own branch of the municipal service. The mayor of a city should understand every transaction and every detail of service in all of the departments; more than this, his judgment should be quick and certain. With the thousands - perhaps millions - of current transactions to master, his control must rest on information accurately classified, well digested, and intelligently summarized, and this should be kept constantly within his reach. The citizen also would know every result obtained; besides, he would have a measure by which the fidelity and intelligence of each officer and agent may be determined. Without this 
knowledge he cannot vote intelligently or exercise judgment with respect to the doings of his many public servants. In each division, each department, and in each office, therefore, a staff must be kept constantly at work arranging the facts of administration around questions that are to be answered for the foreman, the division head, the mayor, the citizen. And as a means of intelligently reporting the answers to the questions, for which these facts have been collected, analyzed, classified, and summarized, it is necessary to have words and phrases that are as exact in their definition as are the classifications and summaries established for the purpose of collecting the facts. Such are the principles and the fundamental necessities which lie back of the need for an exact "nomenclature" and "phraseology" in the subject which has come to be one of the keenest interest to every American citizen - municipal administration.

Answering its wider purpose, municipal accounting should be a scientific or exact method or system whereby all of the financial data pertaining to the management of a city may be currently collected, analyzed, classified, and summarized with respect to problems of municipal adminRelation of istration. Using the same scientific method, accounts and the same exact analysis, the same intellistatistics to gent classification, and the same purposeful administration summaries, a department or bureau of municipal statistics should likewise collect all of the data pertaining to physical properties and municipal service. That is, a well-devised system of municipal accounts and statistics when properly coördinated should give a direct and accurate answer to every question about which the officer and citizen must think. When, therefore, a bookkeeper says that a layman is not supposed to understand accounts, there is either something the matter with his 
books or he is seeking to cover his own ignorance by playing the role of superior wisdom. The same may be said of an officer who answers a demand for information by the excuse that he is not called on to enlighten the public with respect to the work of his department, or, again, that these are matters in which the public is not interested. Either he himself is ignorant of the facts or he is not true to his trust. More often officers are ignorant than mendacious. They themselves have not the information to impart, and there has no way been provided for ascertaining the truth. A most important acquisition to effective municipal control is a system of intelligence, but before a system may be adopted which will supply the information to the ones desiring it, those devising the system must answer the two questions fundamental to the classification of accounts and statistics, viz.: (I) What are the problems of municipal management and control? (2) What information is necessary to their proper solution? After these questions have been answered, we may then decide what name we shall give to each class of facts and to each relation established, i.e., what shall be our "nomenclature and phraseology."

In the first place, a city is a corporation owning property and, as an incident to performing its many functions, incurring financial obligations. Assuming that the properties and financial obligations of the city alone were

Problems of ownership to be administered on - that there were no problems pertaining to the various municipal functions undertaken by the corporation - then in this case what would be the questions of common interest; what duties would devolve on the city's several officers and agents in the discharge of their responsibility with respect to property and indebtedness? Both those in control and the citizen body would know: 
(I) the ability of the corporation to meet its current financial obligations. As a means to this end it would be necessary to ascertain (a) the resources available which may be or are intended to be converted into cash as a means of payment, compared with (b) the obligations outstanding which have matured, or will mature, within the next fiscal period, and (c) the net amount of resources convertible and available in excess of current obligations, or the net amount of current obligations in excess of resources. (2) As a matter of property administration, it is also necessary to know what properties or equipment have been acquired and are set aside to be permanently or continuously used by the municipality, as well as the financial means employed for procuring them. For this purpose no question is asked as to whether they are salable or unsalable, or whether they might be converted into cash as a means of meeting obligations; the point is this, that an accounting is to be had and some knowledge is to be gained with respect to the maintenance and protection of properties which have been acquired and set aside for the continuing use of the municipality, and which are not intended for conversion. An exact knowledge should also be had with respect to the protection of the capital funds provided for this purpose against misuse or misappropriation, as distinguished from the funds or cash available to meet current expenses and liabilities. (3) The officer and the citizen would know what amount of the permanent properties and equipment has been procured from revcnue sources (the invested revenue surplus), and in what manner these funds have been applied, i.e., whether they have been directly appropriated to the purchase of properties, are held in reserve funds, or have been applied to the payment of past obligations incurred as a means of procuring properties and equipment. (4) There should like- 
wise be exact knowledge as to the current increases or decreases in the several classes of properties that are intended for continuous or permanent use, as well as the increase and decrease in the several classes of resources intended for conversion into cash, and for payment of current obligations. (5) For purposes of administrative control, as well as for public protection, each citizen and officer should know something about the fidelity or infidelity of those servants entrusted with public property or funds, for which they have been made responsible.

In the second place, citizens have organized themselves into a corporate body for the purpose of doing certain Problems of things, or exercising certain powers in the municipal interest of public welfare, which they could operation not do, or do as well, in their individual or private capacity. But as a corporation they cannot act except through officers and agents. Looking toward questions of welfare and public service, therefore, it is necessary and proper not only that the officers who are charged with this trust, but also that citizens should know: (I) The amount and character of service rendered by each department or division of the municipality; (2) the total cost of each class of service rendered, or of each function performed; (3) the different current revenue provisions that have been made for meeting this cost, and the total amount that has been derived from each source; (4) whether the current revenue provisions have been sufficient to cover the current cost and the amount of excess of revenue over expenses, or of expenses over revenue; (5) the relation of cost to service rendered as a means of determining questions of economy; (6) the different kinds, and the amount of each kind of financial loss or gain during the period reported on, and under review; (7) the distribution that has been made of any 
surplus as well as the adjustment made as a means of meeting any deficit that has occurred during the period.

In the third place, as the corporate representative of public welfare, the city is empowered to undertake and, on occasion, to accept certain trust or agencies. The Problems of officer in control, as well as the citizen, municipal trust should know (I) the condition of each trust and agency fund or estate; (2) the fidelity of the city in all of its transactions with respect to the administration of these funds or estates; (3) the fidelity of the officer and agent of the city (that is, of its public servants) in dealing with those funds or properties for which each is responsible.

Such, in general, are the problems concerning which we should have full, direct, and accurate answers. The measure of responsibility placed on the citizen, as well as the officer in control, should be nothing less than a complete knowledge concerning, and a complete report on, each of these relations. We come now to the second premise, the classification of the data required for the exercise of intelligent judgment concerning the several problems suggested.

While it is not intended at this time to go into the detailed accounts or classes of financial or physical facts, above suggested, as a matter of gaining a comprehensive

Information required to knowledge of the current financial resources determine abil- know of what these several resources and ity to meet obligations consist. Information of this financial obli- kind should have a classification which
gations

would indicate the cash or current funds on hand, whether the convertible resources are in the nature of revenues receivable, credit contracts receivable, judgments receivable, etc., as all of these several classes of current resources are governed by different laws and 
require a different character of treatment in order to determine their availability or to convert them into cash. For the same reason it is advantageous to know the different classes of obligations to be met, whether they are past due or maturing, as well as the accruing liabilities thereon under contracts for payment of interest, etc. In collecting the facts they should be classified, and finally summarized under these important divisions; and the classification should, at all times, go as far as may be necessary to facilitate thought and to increase efficiency of official control.

In collecting the data pertaining to properties that are set aside for permanent or continuous use, another class

Information of judgments is to be satisfied. The adnecessary to the ministrative problem is one of protection preservation of and preservation of the properties; it has properties nothing to do with conversion. Therefore, the data must be so classified and summarized, that is, such detailed accounts should be kept, that the one in control may know whether the properties are being kept up, how much is being spent for repairs and replacements, what is being done to prevent depreciation, or if the repairs and replacements have not been adequate to maintain the property, what amount it would cost so to replace them, - in other words, the amount of the depreciation. In classifying these facts, it is necessary to sharply distinguish between the data obtained as a means of securing exact knowledge concerning the preservation and protection of properties on the one hand, and that giving the additions or betterments to the municipal plant on the other.

Going to another class of problems, namely, those having to do with cost of service rendered and provision made for meeting cost! For the solution of all questions of economy and for all tests of efficiency, we must have the financial information so classified that the results in units 
of cost may be compared with units of service. It should

Data pertaining to municipal economy and official control be known what amount is spent for salarics, for rents, for heat, for light, for supplies, etc., that the amount paid for each of these may be reduced to standards of economy. Every element that enters into and becomes a part of the problem of economy of administration should be made separate, and a distinct subject for inquiry. The same principles should also govern statistics, by which it is attempted to measure the amount of service that has been rendered at a given cost and the physical wear and tear incident thereto.

About two years ago the League Committee on Municipal Accounts and Statistics undertook to work out the foundation for the classification of accounts. Its first labors were directed toward the question of, What information is desired? This result having been formulated, it next proceeded to the problem of Classification of financial and statistical data, which would furnish this information desired as a matter of current account. These Nomenclature schedules were gone over by the committee and phraseol- as a whole, and having been tentatively ogy adopted were referred to a sub-committee to work out a nomenclature and phraseology that might be adopted as a part of the general report. Within a short time, it is hoped, a compendium of terms may be laid before the general committee. Without assuming to set forth results in detail or to make a report for the committee as a whole, this is offered simply as an exposé of the principles that have governed its action, and to explain the method of procedure by which conclusions will be reached. ${ }^{1}$

1 The sub-committee appointed were: Dr. Hartwell, Mr. Le Grand Powers, and the writer. Mr. Powers has since published an elaborate report on nomenclature in Bulletin 50 of the Bureau of Census. 


\section{CHAPTER XIII}

\section{What Constitutes Reasonable Uniformity in Municipal AcCounts and Reports ${ }^{1}$}

THE administrative functions undertaken by municipal corporations are of three general classes, viz.: (I) Those

Common

functions undertaken by municipalities exercised in the interest of established order and social necessity; (2) those which pertain to social betterment or social elevation; and (3) those which have to do with social economy. Welfare, therefore, as comprehended within the meaning of modern municipal citizenship, and as conserved by municipal administration, must include all of these institutional purposes and activities.

A corporation is a lifeless, bloodless fiction. It is a legal person of sovereign powers - without the ability, however, to exercise these powers except through living human agents. Moreover, these living corporate agents are competent to exercise such powers only as are granted; and again, they are able to perform the functions granted only when provided with physical equipment suited to the accomplishment of the corporate ends. It is in this situation that the advantage of corporate politiCommon cor- cal organization lies. The political powers porate safe- of government (those which pertain to the guards form of corporate organization, and to the exercise of other electoral functions) are retained within

1 Paper read before the Conference of the National Municipal League at Chicago, April 28, 1904. 
the direct or indirect control of the people whose welfare the corporation is to serve; the active administration of the affairs of the corporation is left to agents thus selected or appointed, with authority to direct its functions and to enforce its rights.

To become effective as a public corporation, the service of a municipality (i.e., the living agents into whose

Uniformity in form of corporate organization of municipalities hands the corporate powers and physical equipment are placed) must be organized around the functions undertaken. And the community interests of one politically organized legal society being similar to the community interests of another, the functions to be performed by the corporation organized to serve these interests are similar; for the same reason the structural and legal form of municipal governments bear a close resemblance.

Common provisions for the exercise of political functions are found in constitutional and legal enactments for "the election and appointment of officers." Common provisions for the exercise of administrative functions are found in the creation of departments and bureaus. Distributing the various political offices and the several bureaus and departments of corporate activity in such manner that they may be shown in relation to the common functions exercised, an outline classification would appear as follows:

I. General Organization:

I. For Elections and Appointments.

2. For General Officers and Offices.

(I) Mayor.

(2) Council.

(3) Municipal Courts.

(4) Law officers. 
(5) Finance officers.

(6) City Hall and general offices.

(7) Department of public supplies.

(8) Public printing.

(9) Miscellaneous.

II. Departmental Organization:

I. For the Maintenance of Order and Providing Social Necessities.

(I) Protection of life, health and property.

(I) Police department.

(2) Fire department.

(3) Fire and police telegraph.

(4) Public pounds.

(5) Bureaus of inspection.

(a) Building inspection.

(b) Tenement house inspection.

(c) Weights and measures.

(d) Fuel inspection.

(e) Others.

(6) Militia and armories.

(7) Health department.

(8) Insane hospital.

(9) Cemeteries and crematories.

(IO) Homes for the aged.

(II) Orphan homes.

(I 2) Institutions for defective youths.

(I3) Public lodging houses.

(I4) Outdoor relief.

(I5) Prisons and reformatories.

(I6) Workhouses.

(2) Public highways and sewers.

(I) Building and maintenance of free bridges, 
(2) Opening and grading of streets.

(3) Maintenance and repair of streets.

(4) Maintenance and repair of sidewalks.

(5) Street lighting.

(6) Street cleaning.

(7) Snow removal.

(8) Street sprinkling.

(9) Refuse collection and disposal.

(ro) Sewers and sewage disposal.

2. For Social Betterment.

(I) Public Education.

(I) Elementary schools.

(a) Kindergartens.

(b) Grade schools.

(c) Trade schools.

(d) Special courses of elementary instruction.

(2) Schools of higher instruction.

(a) High schools.

(b) Training schools.

(c) City colleges.

(3) Miscellaneous.

(a) Free lectures.

(b) Other educational services.

(2) Public libraries, art galleries, and museums.

(I) Public libraries.

(2) Public art galleries.

(3) Public muscums.

(4) Public aquariums.

(5) Zoological gardens.

(3) Public recreation.
(I) Public parks. 
(2) Public playgrounds and gymnasiums.

(3) Public baths.

(4) Public celebrations.

3. For Social Economy.

(I) Municipal Industries.

(I) Water works.

(2) Gas works.

(3) Electric light plants.

(4) Municipal heating.

(5) Street railways.

(6) Municipal subways.

(7) Municipal conduits.

(8) Municipal markets.

(9) Municipal docks and warehouses.

(Io) Municipal ferries.

(I I) Municipal toll bridges.

(I2) Muricipal ice plants.

(2) Municipal Investments.

(I) Real estate.

(2) Stocks and bonds.

(3) Other investments.

In none of the cities do we have all of the departments of service above shown; but in all of them, in so far as the service is organized, the relations indicated are present. From the point of view of functions undertaken and of organic provisions made to perform these functions, therefore, a common basis for classification is found. With this all the data pertaining to either the political or administrative activities must be associated.

The form and classification of accounts are necessarily determined by the form and purpose of organization. Municipal administration is largely a matter of business. 
In a free society the services employed by a public corporation must be voluntary and, therefore, a subject of contract - i.e., one of offer and acceptance. In most of its aspects the exercise of administrative powers rests on bargain and sale, while even in its political and governUniformity of ing functions the corporation must have

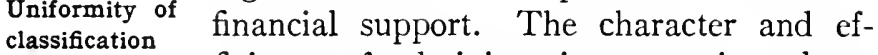
ficiency of administration must in a large measure depend on the character of business judgment exercised by those in administrative control; in an institution having such variety of transactions and such complexity of organization (one whose business in the aggregate amounts to many thousands or even millions of dollars), the exercise of sound official discretion depends on a system of financial account and statistical report which will not only record each transaction in its proper administrative relation, but which will also reflect, in properly classified summaries, the net administrative results.

Municipal accounting has been defined as a method employed by a city for the purpose of recording its business transactions, and finally coördinating these data around problems of administration. A system of accounts employed by a city, if true to this purpose, must, like the administrative Service itself, take its form and character from the form and character of corporate functions exercised. The same is true of statistical reports. As a principle of uniform classification in municipal accounts and reports, this is not stated as a possibility but as an administrative necessity. Such uniformity as is found in the functions undertaken by the various municipalities, and such as is reflected in common forms of organization, require that the general categories for the final summaries of account and statistical report in one city be similar to 


\section{REASONABLE UNIFORMITY IN ACCOUNTS}

those of another. This is the assumption which lies at the foundation of the work of the Committee of Uniform Municipal Accounts and Statistics of the National Municipal League.

Proceeding from this assumption, the committee of the league on uniform municipal accounts and statistics has, till recently, turned its energies entirely toward the

Schedules of the committees discovery of those functions and forms of organization that are common to municipalities. For guidance they have gone to the charters and organic laws; they have also availed themselves of the results of research of political scientists, and of the experience of professional accountants and officers of municipal control. Each result has thus been brought to a critical test. So useful were the schedules of classification thus formulated, that, from the date of their first publication, they have been utilized by cities attempting to restate their reports. In fact, the progress of the work of the committee may be traced in the new classification from time to time adopted by municipalities. To-day there are no less than eighty cities whose financial statements bear the stamp of the work of the league; and the United States Census officers have made use of them in the collection and classification of municipal statistics. At the last conference of the league it was thought the success of this part of the work of the committee warranted an enlargement of the scope of their labor. The committee was therefore continued and instructed to report in outline a complete system of municipal accounts and reports.

It is to be held in mind that up to this time no attempt had been made by the committee to apply its classification to any part of the accounts of a city, nor to any part of a municipal report except to "Receipts and Disburse- 
ments." And the use that had been made of the schedules by the cities themselves had largely been under the same limitation. Till the time of the last annual conference of the league only three cities had adopted complete systems of accounts, in which attempt was made to apply the classification of the league, and two of these systems were then in process of installation. Chicago was the only city that had made a report after having adopted such a system of accounts. In this (the comptroller's report for 1902), the application made of the schedules had been to Revenues and Expenses of the city, instead of the transactions of the treasury (i.e., to Receipts and Disbursements). Thus, as before, the "larger work" to be undertaken by the committee was in the nature of pioneering.

To answer the specification of "completeness" the committee must outline a plan by which all of the transactions pertaining to municipal activity may be classified

The larger work of the committee - i.e., it must not only include the transactions of the treasury and mark the flow of cash, but it must also take into account the transactions and the properties pertaining to every other department and municipal relation. The success of the committee in introducing a "uniform" system must depend on the adoption of a classification of detailed accounts from which the central controlling officers may bring the work of the bureaus and departments into relation with the common problems of municipal administration, and which in turn might be used as a basis for financial report. To accomplish such a task, to devise schedules which may be acceptable and serve as a basis for uniform accounting, is an undertaking that will require years of continuous effort and must reflect the technical knowledge and experience of a large community 


\section{REASONABLE UNIFORMITY IN ACCOUNTS}

in interest. The service which the committee hopes to render is the one of bringing this knowledge and experience together and of expressing it in intelligible form.

The initial work of the committee was to obtain a formulation which might serve as a working hypothesis for discussion and by means of which this experience might be drawn out in conference. The scope of the committee's investigation was to include the physical and operative statistics of cities, as well as their financial accounts and reports. At the first meeting held, the first draft of that part of the programme which pertained to statistics was assigned to the chairman and the preliminary draft on the outline of accounts and financial reports was assigned to the secretary. This draft was formulated and submitted to the committee February, 1904, and tentatively adopted, but no final action was taken. It was this draft that was placed in the hands of Mr. LeGrand Powers, of the bureau of census.

The application of schedules of uniform classification to a complete system of accounts, and finally the evolution and statement of principles of uniformity, require that we first ascertain the categories of classification common to municipal accounting. Accounts being devised as an aid to clear thinking about the affairs of a city, the discernible uniformity that may exist must have reference to the elements of common interest in administration.

As before suggested, we have to deal with a corporation - a legal entity with sovereign powers and proprietary rights, the purpose of whose creation is to render Uniformity in service to the community, but which can principles of exercise powers only through officers and accounting agents equipped with the physical means necessary to make them effective. This corporation, therefore, so far as its business is concerned, has two 
distinct relations, the one being with respect to its own proprietorship (its assets and its liabilities), the other being the business aspect of its operations (the corporate income and expenses).

Reflecting these two relations there have grown up two distinct systems of account, either of which may be used and either of which may be complete. The most primitive of these is what is known as a single-entry system; it attempts to exhibit in form of final statement one relation only - that of asset and liability. That is, in a single-entry system of account, its final summaries are set up in what is known as a balance sheet, or an exhibit of present proprietary conditions; in its final statement it attempts to give an instantaneous photograph of properties and financial obligations of the cities. The other, known as the double-entry system, attempts not only to state relations of asset and liability, but also to give a classified summary of operations. In this a financial biograph is given of the fiscal period; also an instantaneous photograph of conditions at its close. Before we attempt to outline a scheme of uniformity of accounting, therefore, it is necessary to decide as to which of these two systems of account will be used. And this in turn must again be decided by appeal to corporate purposes.

What are the administrative interests common to municipalities? Are statements reflecting corporate conditions in terms of asset and liability sufficient? What are the problems about which both electors and responsible municipal officers must exercise discretion? Administrative Generally speaking, there are two classes problems com- of administrative problems pertaining to mon to mu- the management of every public corporanicipalities tion: (I) The citizen, in his judgment of the administration, and the controlling officer, in the 
performance of his duty, wish to know whether or not the corporation, as an agent of general welfare, has rendered the best service of which it is capable at the least cost; (2) and, as a corporation necessarily owning properties and intrusting its funds and equipment to officers and agents, all parties in interest desire to know whether or not this proprietorship has been protected against misuse and infidelity. To supply the data essential to intelligent judgment, a complete double-entry system of accounts is requisite.

From this we may proceed to a consideration of the essentials common to accounts. Accounts being a method of collecting, classifying, and coördinating business data, Essentials com- we look to the adequacy of means. A mon to ac- complete system would require that every counts transaction be recorded. This should be done by the person in charge if possible, at least by the bureau or department in which the transaction arises. In a large city, however, chronological record of events kept in each department could be of little use to any one. To utilize this unclassified historical record and adapt it to the purposes of control, the various transactions must be classified, and this having been done they must then be brought into statements of final account prepared for a central office. Both the "original entry" and the first "classification" may take place in the department. From this the classified result is reported to the central office the items contained in this report must be "posted" to the central or controlling accounts. The classification of "controlling accounts" therefore must determine that of the "detailed account" of the transactions in the departments.

We now come to the classification of the "controlling accounts." These being organized around the two gen- 
eral administrative categories (viz.: "municipal economy" and "municipal proprietorship"); within these two general categories there are also some common interests which require uniformity in statement. The relations of economy are determined (I) by comparison of expenses with the statistics of service performed. This not only introduces us into the categories of expense and income, but also in the other branch of the committee's investigation, viz., physical and operative statistics.

Confining ourselves to the accounting side of the problem, all cities derive their income for the support of government from about the same sources, viz., from taxes, licenses, and miscellaneous fees of departments, etc. common clas- Organizing accounts of income accruing sifcation of for the use of a city during a fiscal period income and according to sources, we have a common expenses basis for the classification of revenues. Statements of taxes are taken from the tax levies; licenses may be taken from license registers; and the miscellaneous fees, etc., are reported from the several bureaus and departments. For the statement of miscellaneous revenues, the schedules of the league would form a common basis for classification. The expenses are also recorded in the office of the comptroller in the form of expense vouchers, etc., or are reported from the department. Here again the schedules of the league, based on administrative relations common to municipalities, may serve as a guide; and such a classification would be of the highest utility. It may be said it is absolutely necessary in getting at relations of economy of administration when reduced to cost of units of service by comparison with the operative statistics.

One of the most important proprietary relations of a public corporation, and one which involves a problem 


\section{REASONABLE UNIFORMITY IN ACCOUNTS}

most serious to the officer as well as the citizen, is that

Common basis for classification of asset and liability accounts of ability of the government to meet its maturing obligations. A proper accounting of this relation requires a classification of assets and liabilities in such manner that the properties intended as equipment, or for continued use in the business, may be segregated and set apart from assets to which the city may look as a means of payment. Quite as important also is classification of liabilities in such a manner that the current or maturing liabilities may be distinguished from those long-time obligations that are not a current charge. These relations having been set up, judgment as to the ability of the government to meet its maturing obligations requires that the current liabilities be compared with the assets available to meet them. The classification of the current asset and liability accounts should be similar in the accounts of cities for the reason that the assets are derived from similar sources, and the contractual and legal liabilities are similar in kind. If such comparisons are to be made, therefore, there must be uniformity in the general controlling accounts of current asset and liability.

The long-time liabilities are usually incurred for purpose of equipment or permanent improvement. The general classification of equipment used by the cities being the same, uniformity in the controlling accounts of both bonded debt and of the permanent asset accounts follows - and in the schedules of the league may be found a common outline as well as a common nomenclature. In conclusion it may be said that whatever be the difference in forms of records used for "original entries" of transactions in the various bureaus and departments, common administrative interests and purposes of control would suggest a common classification 
of the general controlling accounts of municipalities. Not primarily as a means of bringing the records of one city into comparison with those of another, but as an essential to enlightened conduct of its own affairs.

We turn now to the accounts of special officers and departments, in which the prime purpose is to insure

Departmental accounts showing relations of fidelity fidelity. Aside from the fact that a department record is an integral part of a general system and for this reason the truth of departmental records is essential to intelligent controlling summaries, the officer entrusted with properties or funds must also render an account of his stewardship. One of the most important of these departmental records reflecting relations of fidelity is that of the municipal treasury. So far as the general asset and liability statement is concerned, no return is needed except that of "balances on hand"; to this end no classification is necessary except that the "current cash" be returned separate from the "cash obtained from bond sales for permanent improvements," etc. But from the point of view of official fidelity, a statement of "receipts" and "disbursements" should be made which will reflect the transactions pertaining to and the final condition of each fund kept.

In this I am somewhat at variance with those who have attempted to use the cash-book as the central record of municipal account, and even with the use that has been made of the schedules of the league in many cities; in some of these, receipts and disbursements are reported according to a classification of revenues and expenses, irrespective of treasury funds created.

For administrative purposes money received should be shown by the treasurer in his report according to the sources from which these receipts have been derived. 
Money is not revenue. Money is an asset. It may be deClassification of cash receipts rived from "taxes receivable" or "accounts receivable" or from "judgments receivable"; from sales of bonds or other "credit contracts payable," or from the sales of properties. The receipt usually has a direct relation to an asset or liability account. The treasurer, therefore, in his classification of receipts and for the purpose of making his report, should have direct reference to the source from which the money came. The common source of money receipt is the common basis for the one side of the treasurer's report.

When money is received, it is entered directly to the credit of a fund to which that particular class of receipts Classification of disbursements

has been apportioned, or it goes into the general fund of the treasury, from which appropriations are made. The books of a treasury should be kept with respect to the funds created and the disbursements from each particular fund should be separately stated. These funds are created by appropriation. There is absolutely nothing gained by trying to show on the books of the treasury the purpose for which a payment is made. This summary is made on the books of the comptroller in entering up the warrants and vouchers to the "expense" account, or "asset" or "liability" accounts affected. The treasurer knows nothing about "expenses," "assets," and "liabilities." He knows only "rnoney," "money" funds appropriated, and the order or warrant of a duly qualified officer for the payment of "money." The common basis for uniformity in classification of disbursements will be found, therefore, in the similarity of funds carried as a result of municipal appropriation.

Such may be stated as the common principles which lie 
at the foundation of any system devised, which we, as a committee, may hope to have adopted by municipalities.

\section{Conclusion}

Such uniformity as may come into the accounts of cities must come for the same reason that there is uniformity in the human anatomy, or in the conclusions reached by the human mind when reasoning from common premises assumed - it must come as a result of the device adopted being adapted to the purposes and ends of municipal organization and administration.

Looking on the problem that confronts the committee, and recognizing that the character of the accounts must be governed by the comptrolling purpose, it was thought The form of that the first classification concerning which comptroller's agreement should be reached is that which report pertains to the central or controlling accounts. But since the purpose of the controlling accounts is that of obtaining summaries of results, which are needed by citizens and by officers in responsible positions, it is esteemed that consideration of the form of statement of the comptroller's report should be first obtained. To this end such a tentative draft has been submitted to the committee for further consideration and deliberation on its part. 


\section{CHAPTER XIV}

Municipal OwNership as a Form of GovernMental CONTROL ${ }^{1}$

In the eighteenth century, theories of democracy were in the nature of protest against government regulation and control; these theories found expression in political and economic doctrines of laissez-faire. To-day the situation is reversed. Having succeeded in reducing government to forms of political responsibility there has been

The transition from economic individualism to economic centralization a gradual increase in the demand for the exercise of federal and state control. A summary statement of the successive steps in this evolution may serve to bring the present situation into clearer light. They appear about as follows:

(I) Government regulation of matters of business by the early establishment of the principle of a protective tariff and by the organization of a federal bank.

(2) The granting of direct aid to commerce and transportation.

(3) Federal regulation and control over the foreign trade and the shipping interest of the East by federal embargo and non-interference Acts, thus forcing New England and its economic institutions into alignment with prevailing national ideals with respect to internal improvement.

- Paper published in the Annals of the American Academy of Political and Social Science, November, I906. 
(4) Federal interference with the social and economic institutions of the South by military force, compelling a complete industrial reorganization there.

(5) The enactment of laws, state and federal, the motive to which has been the more rapid development of national resources by increased grants of corporate privileges, market monopolies, etc., the net result of which has been to encourage the building up of great capitalistic and labor combines that latterly have been able directly or indirectly to control practically every branch of business.

Thus, employing agencies of government as a means of giving direction to investment and private undertaking, the transition from economic individualism, as it existed one hundred years ago, to an economy based on group activity and highly centralized administrative control, as it exists to-day, has been rapid. We have reached a state of social and industrial organization in which, from motives of self-interest, nearly all classes combine in making political demands for a still stronger hand of the government in the exercise of control.

Capitalists, enjoying franchises and privileges, ask that the integrity of their corporate estates and capitalized incomes may be guaranteed; laborers, having organized for mutual advantage in making contracts with capital The newly de- for wages, demand that the hours and conveloped interest ditions of labor may be regulated; creditors in government and investors contend for public inspection control

and for legislation giving them added facilities for control over corporate agents; beneficiaries of trusts would have a more strict law for institutional trustees; independent civic societies are seeking prohibitive, regulatory, and mandatory legislation with respect to public education, child labor, and other measures for 


\section{OWNERSHIP AS A FORM OF CONTROL}

social betterment and looking toward a better adjustment to the new order of things; citizens as a whole, on the grounds of general welfare, urge increased government action prohibiting monopoly regulating forms of association and providing a more effective means for group control. The phrase "The Trusts" suggests at once a condition of capitalistic organization and private monopoly advantage as well as a subject with respect to which increased powers of government are to be used.

How are these enlarged powers of government to be employed? By what means may we best retain the benefits of broad coöperation and at the same time direct and control group activity for great common good? It is only with respect to the method of accomplishing this end that our recognized political leaders and political

Forms of control proposed platforms are at variance. In matters of legislation, conservatives would "stand pat," claiming adequate remedy in a better enforcement of the present law. Among those less conservative, one national leader would have enacted radical legislation looking toward public regulation of "the Trust" and restricting inheritances. Another would reduce monopoly advantage by the abolition of market constraint and would increase the possibilities of government control by limiting and restricting corporate franchises. Another sees no remedy adequate to cope with centralized capitalistic influence over interstate public service activities short of government ownership. Still another argues for a socialistic state.

Reasoning from similar conditions on questions of local welfare, measures are proposed for increasing the activities of municipal government among which both the doctrine and the practice of public ownership has been fast gaining ground. With respect to the munici- 
palization of public service activities there are three distinct schools of opinion: The first, and in most cities the predominant group, we may call conservative - clinging Doctrines of to a modified form of the ancient doctrine control as ap- of laissez-faire. This doctrine is strenuplied to cities ously urged by those who would not have the present order disturbed. A second school holds that in circumstances where the public welfare demands it, the cities should take over public service enterprises, as has been done in the cases of the subway in New York and the gas works in Philadelphia, for purposes of exercising proprietary control, but that for political reasons the city should not attempt to operate them. A third school insists on both public ownership and operation as offering the only effective means of protection.

For purposes of proselyting, both argument and illustration are arbitrarily chosen. Each school proceeds from an assumed premise of public welfare. Those opposed to the municipal ownership of public service enterprises point to the prevalence of political graft; to increased patronage; to increased inducement Arguments to bribery and electoral corruption; to inbriefly stated evitable political appointments - all of which are opposed to efficiency and economy of service. Those who advocate municipal ownership argue that an increase in functions will increase public interest in government, will carry with it a choice based on fitness that is equal to the new and increased responsibility; that the present inducement to use corporate influence on legislative and judicial bodies will in a large measure be removed; that the public service will be improved because it will be more responsive to public demands; that public charges will be reduced because they will be laid on the basis of cost of operation 
instead of being laid on the principle of "what the traffic will bear," as is the case when these activities are performed by private corporations. In each case the conclusion reached is an absolute one. The solution offered is regarded as specific - as if there could be neither alternative nor doubt.

THE QUESTION OF SUCCESS OR FAILURE OF MUNICIPAL INDUSTRY A CONDITIONAL ONE

The fact that success or failure of such enterprise necessarily must be relative, and that this relation is one which has to do with administrative conditions, seems to have been quite overlooked in the controversy. Assuming that a municipal industry may be managed with the same economy, efficiency, and fidelity as a private industry,

Fundamental considerations even then the question as to whether the city should embark on a particular enterprise is to be determined by conditions. From the point of view of public welfare the citizen must consider: (I) whether, after including interest charges on capital in the cost of the service, the price to the public of the same service may be materially reduced; (2) assuming that there would be no reduction in charges to the public for service rendered, will the control obtained over the enterprise which may be secured by public ownership be adequate reason for the change?

To state the case conversely: assuming that the actual cost to the private corporation of rendering service (including a fair return on capital) is less than the price charged to the public, then the questions for the citizen to answer before he accepts the conclusion of advocates of public ownership are: (I) Can the enterprise be as economically and efficiently managed under municipal authorities? (2) If it is conceded that it may be as eco- 
nomically and efficiently managed, will the charges for service be materially reduced? (3) In case the price may not be materially reduced, will public ownership render the service more responsive to legitimate public demands and contribute more to the convenience of the city as a whole? If these questions be answered in the negative, then it were better to retain private ownership and operation. But there is still another question that is avoided by this assumption: Is the government so organized and the business of the city so controlled that an economical and efficient administration of the functions may be insisted on and enforced?

In each case presented the question as to whether a city should own, or own and operate, is not to be answered by a priori reasoning and arbitrarily, but in relation to two factors: first, what are the conditions precedent to the successful administration, and, second, are these conditions present in the city which has under consideration the particular municipal venture?

CONDITIONS PRECEDENT TO SUCCESSFUL OWNERSHIP AND OPERATION OF ENTERPRISES

Considered administratively, the elements of successful management of municipal enterprise are the same as the elements of successful management of private enterprise. In each are the same problems of capital cost, the same problems of construction and equipment, the same questions to be dealt with in operation and mainAdministrative tenance. The differences are not differences elements the in principles of administration, but differsame whether ences in methods of control and in methods public or pri-
vate

control differ only in the character of contract by which service is obtained. In public enterprises 
the personnel of organization is obtained by a form of contract known as political appointment; in private enterprise the personnel of organization is obtained by contract of employment. In each, however, the intelligence of control depends on the adequacy of means of obtaining information as to the efficiency of the service and the economy of operation -- on methods by means of which personal responsibility for results may be enforced. Public enterprise is capitalized, maintained, and operated for public gain ; private enterprise is capitalized, maintained, and operated for private gain. In public enterprise the distribution of gains to citizens is in the form of a lower price or better service rendered; in the private undertaking gains take the form of surplus and are distributed to the stockholders as dividends. While, therefore, the financial scale by which distribution is measured is a different one, the elements which go to make administration successful, and the standards for measuring the quantitative administration results or gains to be distributed are exactly the same, viz.: Economy, efficiency, and fidelity of management; in each case administrative questions revolve about these three categories.

If the citizen ask himself the question as to whether his municipality may succeed in the management of a given industry, the answer must depend on whether or not this particular municipality may procure agents who will Efficiency, econ- manage the industry with economy, effiomy and fidel- ciency, and fidelity, and not on what some ity of govern- other city has accomplished. What assurment essential ance have citizens that the proposed underto success

taking will be so managed? This assurance must lie in the same principle of government that is applied by the Standard Oil Company or by any well-managed business corporation. Some provision must be made 
not only for procuring a type of intelligence in management competent to exercise the sort of discretion required, but also for a complete and effective means of obtaining information necessary to such discretion in the exercise of administrative control by the officers having the business in hand. There must likewise be provisions made for bringing home to citizens at large the results of management in order that official responsibility may be enforced through the election of a board of aldermen or a chief executive.

The problem of intelligent and efficient municipal ownership and operation of industry is a problem of the same kind as that of intelligent and efficient government. It Standards for differs only in this, that in the industries judgment re- the results of mismanagement or the results quired

of misjudgment are subject to more exact measurement by well-established and well-defined business standards and may be brought into favorable or unfavorable comparison with results obtained through private organization.

\section{THE PROBLEM OF INTELLIGENT CONTROL}

Analytically the prerequisites of intelligent administrative control may be stated as follows: (I) An organization adapted to the business purpose by means of which managing competence may be secured; (2) a means of obtaining accurately and currently the data necessary to the exercise of intelligent judgment with respect to questions of adminstration; (3) a means for enforcing individual responsibility in the service.

Managing competence must in a large measure come through experience. To procure a successful and experienced manager, or retain such a manager when developed, and at the same time provide the means whereby the gen- 
eral policy may be made to respond to demands of citizens The character or stockholders, is the underlying principle of organiza- of efficiency in corporate organizations. This tion

principle has been regarded as of highest importance in private business, and in its development there has been evolved a highly centralized executive responsibility. With a highly centralized executive those who are competent have been retained as a matter of executive advantage. When, in response to a change in stockholding policy, the chief executive officer has been removed or supplanted by another, the new president of the company, in his own interest, may retain any and all of the former departmental heads in order that he may avail himself of the best experience in the successful prosecution of the enterprise. Being held to strict account for administrative results, he has not filled the ranks of the company with his own friends, for the reason that such a course would have worked his own destruction. In any large corporation, the president's success must be attained through his subordinates, and being constantly measured by standards of economy and efficiency, certain it is that his reputation for success will not be enhanced by supplanting an old departmental head by some one less competent.

The trend of American municipalities in charter-making has been to follow this principle of private corporate organization. The great defect in municipal administration has not lain in failure to make provision for the exercise of executive powers, but in the lack of means in the hands of a chief executive for determining the economy, efficiency, and fidelity with which operative departments of government are managed. Not having this intelligence, and there being no provision made whereby the citizen may hold the chief executive to strict account, the 
tendency has been to extend political influence beyond the chief executive himself and include the personnel even of industrial department activities within the patronage to be dispensed by the party boss.

Turning now to the second essential, there are two general branches of corporate service by means of which those in responsible administrative positions can keep themselves informed with respect to the doings, economy, efficiency, and fidelity of their subordinates. These two arms of administration, by means of which information is collected, are inspection and accounting. The method used to convey information collected to the proper head is reporting. When the business has come to be so large

The means for promptly obtaining accurate information that the one at the head may not have immediate contact with its every detail, intelligent management requires that complete and accurate information be regularly brought to the attention of administrative heads through branches of the organized service, i.e., through subordinates. So far as the results may be numerically and financially stated, this information may be furnished by means of a well-devised system of administrative accounts and statistics. So far as information has to do with the quality of the materials furnished, with service performed, with the physical condition of properties, with the number of employees actually in the service of each department, with the attitude of subordinates toward their work, and their fidelity toward the institution in whose service they are employed, the accounts must be supplanted by inspection. The administrative value of facts obtained depends on its accuracy, its completeness, and the promptness with which it is brought to the attention of responsible heads. These two branches or arms of administrative control 


\section{OWNERSHIP AS A FORM OF CONTROL}

(independent of each other, but each responsible to the executive head) are the means by which the most difficult, complex, and widely extended corporate activities are intelligently directed. Without these two branches of the service effectively organized, large corporations would fall a victim to their own impotence and incapacity. In order that a system of accounts may be adapted to such a controlling purpose, adequate provisions must be made for an accurate record of all the varied details of the business, as well as the collection and summarization of these data about the problems concerning which those in controlling position are required to think. A system of accounts which falls short of this mark does not measure up to administrative needs. Inspection as a branch of control must cover every physical and operative relation which does not come under the personal scrutiny of the executive, or which, owing to its nature, may not be regularly and promptly reported in the accounts.

\section{DEFECTIVE ADMINISTRATIVE CONTROL IN CITIES}

Administration comprehends two distinct subjects of controlling intelligence: (r) That which pertains to property and funds, and (2) that which pertains to service rendered and operation. In the American municipality great care has been exercised to obtain a strict accounting for funds. Every caution has been drawn around monetary receipts and disbursements, but with this the accounting has practically ended. In but few municipalities (and these within the last few years) has any attempt been made to introduce accounts which will reflect economy, efficiency, and fidelity of management. Few have attempted to keep an account even of properties. In the great cities, like New York, Philadelphia, and Boston, there is no way in which the chief executive may inform 
himself accurately and regularly on questions of current business with respect to the water departments, the cost to the city per kilowatt of electric light manufactured at municipal plants, or the cost of operating other municipal enterprises. How may he intelligently think about matters of economy and operative efficiency in these departments? How may he know whether the city is charging too little or too much for water? How may he know whether the head of the department is supplying water to certain large users who can afford to be generous toward the city's employees without adequate compensation being made for the same to the city? How may he know if water rents are properly collected if only cash receipts are reported? How may the head of the department himself know whether the pumping or storing is being economically done? Whether adequate provisions are being made to keep the mains and reservoirs in repair. In so far as he has an intelligent basis for administrative control, this at present comes through inspection and not through operative accounts and statistics. By methods of inspection he may keep the property in running condition, but he may know little or nothing about questions of economy and may obtain only a half view of efficiency. Were private corporations to rely on similar methods of administrative control, they would be quite as loosely managed and quite as incompetently manned as are our municipal industries. So soon as we have efficiency in government, we may efficiently manage public industries. Until we do have efficient government, not only may we not construct public works with economy, but our great municipalities will also suffer even more from incompetence and infidelity in protection of life, health, and property and the promotion of public education and public morals. 


\section{4

Certain cities have recently responded to demands for accounts and reports by means of which administrative results may be shown. Some of these, however, are making little or no use of these accounts after they have been introduced. The financial operative results are not

The estab-

lishment of standards for judgment being coördinated with physical operating facts, the outcome being that the people know little more about the affairs of the city than before such accounts were introduced. The fact that the operating cost of water is $\$_{3,000,000}$ per year, gives little information, either to the citizen or to the official, more than might be obtained by the old method, which reported $\$ 5,000,000$ per annum had been disbursed by the department. The only differerence in the form of statement is that the operation account clearly distinguished current expenses from betterments. But to make $\$_{3}, 000,000$ intelligible, either to the administration or to the citizen, this amount must be divided between the cost of pumping and storage and the cost of distributing; more than this, every division of cost must be interpreted in terms of some standard of judgment such as gallons produced, and, so far as possible, this result must be classified by districts or stations or other operative groups for purposes of showing administrative relations. If need be, as a part of management and as a means of determining administrative facts to be reported, there should be meters put on the pumping and distributing mains. Some method should be applied for determining whether, and where, there is an excessive wastage; what the amount pumped at each station; what the amount distributed through each main; in whose official district the wastage is large, etc. The administrative bearing of such information does not end with fixing responsibility, but enables the officer in control to think 
whether the rates charged are adequate, and to efficiently direct the management in the interest of economy. Until some plan is adopted by cities by means of which ordinary intelligence may be exercised in the management of municipal affairs it would be worse than foolish for a city to attempt to manage industry and to compete with private corporations offering to perform public service.

Another consideration which has to do with the enforcement of responsibility: Assuming that adequate method be provided whereby economy, efficiency, and fidelity of service may be established, and that this method may be such that every one in responsible position may be conEnforcing re- fronted with his own record, it is important sponsibility for to know whether or not executive control results

may be enforced. It has been noted before that private and public enterprises bear this marked difference: that private service is by contract of employment; that political service is usually by contract of election or appointment. This difference has a direct bearing on administrative discipline. To make the municipal problem more complicated, civil service reform measures have been interposed which, with the present means of accounting and inspection, practically render responsible heads of departments and chief executives helpless in the face of a combination of inefficient municipal employees. Not having a method of inspection and account by means of which evidence of each act and transaction is produced and preserved, and not having a method of promptly reporting the facts supported by such evidence, executive and subordinate responsibility is left unprotected, established policies are unenforced. The chief of the administration, as well as departmental heads, have no legal ground on which they may stand before a court in action for removal or discipline; they have no claims which 
may be supported before the people other than those of partisan character. As a result, remedy for the spoils of patronage has been sought in measures called "checks and balances," practically taking away from those in directing position the power to efficiently manage and direct.

But lack of means necessary to the enforcement of the responsibility is not alone applicable to disciplinary acts. The heads of divisions, even the heads of departments, may not be held to an intelligent responsibility for operative results. About the only information which comes regularly to the mayor has little or nothing to do with the administrative duties of his office. He is in a position to be promptly confronted with complaints or refusal to perform acts demanded of subordinates by a political boss, or to have heads of departments convicted of offensive partisanship; but so far as the manner in which the department or municipal activity is managed, he has little to show by way of defense, nor has the mayor, as chief executive, adequate data for judgment on issues presented.

The same situation prevails with respect to the responsibility of the mayor to the people. Being held legally responsible for the official acts of heads of divisions of the service, and for knowledge with respect to the doings of each department, he not only does not have before him the information essential to intelligent judgment on matters of public business, but he is unable to render an intelligent report of his own doings. He may not even act intelligently on the annual budget. In consequence the mayor falls victim to the shifting fortunes of the political boss whose creature he is made, or having been elected independently of party, is swept aside by a wave of popular prejudice raised on an issue of duty without anything to 
show for conscientious service rendered. So long as this condition prevails, municipalities are not in a position intelligently to undertake the ownership and operation of industries.

\section{CONCLUSION}

Intelligent ownership requires that there may be an intelligent method whereby the duties and responsibilities of proprietorship may be performed. Even as owner of a gas plant company without operation, there should be required such an account of stewardship and such an inspection as will inform the city official and the citizen whether or not the plant in the possession of the private corporation is being adequately maintained or, if not adequately maintained, whether an adequate reserve is being made for depreciation. A municipality which would own and operate an industry has the problem of proprietorship compounded by all of the problems of operation and all the problems of service.

Just so soon as cities provide the means for intelligent control, for the protection as well as the enforcement of managing responsibility, for the reward of the efficient and the faithful and the degradation of the inefficient and the time-serving civic infidel, just so soon will it be prepared to undertake functions now performed by private corporations and to perform these functions in a manner not only creditable to themselves but in harmony with the highest welfare of the people. In the meantime the evils to be feared or which have been realized in municipal ownership will have to be balanced against evils complained of at the hands of public-service-private corporations and, as in Philadelphia, the people will continue to flee from evils known, in a system in force, to evils unknown, in a system which offers itself as a temporary expedient. The public service will be kicked and bantered 
about as is the municipal official who, be he true or be he false, is carried away by partisan policies or in a response to the cry of the demagogue to "sweep the rascals out."

Asking for increased government control, should not the American people premise this request on an insistent demand for increased intelligence concerning the management of business affairs? Until adequate provision has been made for such intelligence, increased government control through public ownership and operation may not safely be undertaken. Is not citizen organization and citizen endeavor which looks to methods of business and a knowledge of results, an organization which will insistently strive through publicity both for an enlightened electorate and an intelligent directorate, the missing link between government for the satisfaction of personal greed or graft and government for the common good - the introduction of the principle of the old town-meeting into the modern metropolis, with the methods necessary to make this principle effective? 


\section{CHAPTER XV}

\section{Chicago's Accounting Reform ${ }^{1}$}

As secretary of your Committee on Uniform Municipal Accounts, I am requested to report on the Chicago situation. This report was to have been rendered by Mr. Haskins. His long professional experience had made him an authority, and his appreciation of the need for a broader basis for the classification of municipal accounts had brought him into enthusiastic coöperation with public accountants and other professional men who make up the working membership of your committee. What is more to the point, his accounting firm for the last two years has had immediate charge of the installation of the new system on which this report is to be based. Mr. Haskins' sudden death, ocurring only a week after the last meeting of your committee at his home Charles Waldo in New York, together with the expressed
Haskins desire of the secretary of the League to have this - the largest accounting operation to which the schedules of the committee have been applied reported on at this time, are the conditions under which this hastily prepared essay is undertaken.

Two years ago Mr. Haskins made a brief report to the Municipal League on the subject in hand. His professional firm had then just entered on an investigation which has led to the present result. In this preliminary report

1 Paper read before the Ninth Annual Conference of the National Municipal League held at Detroit, Michigan, April 23, I9०3. 
Mr. Haskins set forth some of the conditions which made necessary a revision of the financial records of the city. The situation was gone into in greater detail in his report to the Merchants' Club. For perspective, these conditions may be briefly restated: Within fifty years Chicago had grown from a frontier village to a municipality of two millions; it had begun with the small town organization; as its population and territorial jurisdiction had spread over the surrounding prairies and swamps, these primitive local town governments had been incorporated by annexation rather than by process of readjustment and reorganization. The municipal child had so rapidly

The growth of Chicago grown to manhood that its political dress was a constant misfit; its clothes were too small and the neighboring youths over which it stood as a foster brother refused to give the cloth necessary to complete a'decent cloak of authority; - the last pattern had been designed for a city of about one-fourth its present size.

The city of Chicago had finally come to include more than twenty separate taxing jurisdictions, over which it had little administrative control and between which there was no well-defined method of coöperation for common ends; the financial side of the administration had become unmanageable and the government in all of its activities was crippled. Recognition of this situation on the part of both citizens and administration was the first step toward reform. Citizen activity and discontent were in evidence on every side. The administration had four The situation grave facts confronting it which seemed to reflect on the government. In the first place, court judgments had gradually accumulated against the corporation until, on January I, I900, they were known to amount to over three million dollars; these, however, had 
not been properly incorporated into the accounts of the city. In the second place, it was found that the funded debt of the city was much larger than represented on the books. In the third place, it was discovered by the comptroller that previous administrations had been using trust funds for running expenses. In the fourth place, the methods of accounting in use failed to show the amount of taxes assessed and uncollected. That something must be done was apparent, and in the face of an active public opinion the administration was in such position that it could protect itself only by a thorough revision of accounts.

The mayor of the city of Chicago was alive both to the public demand and to the probable results of public censure in case his own incumbency were mayor of not relieved from suspicions which were sure to follow. In his annual message he commended the insistent agitation of citizens for municipal reorganization and for central control; he urged the "welding of the present taxing bodies exercising municipal functions within the limits of Chicago into a harmonious whole, by which useless officers may be dispensed with and all the various municipal functions may be combined intelligently under individual control."

The means adopted to accomplish this end were largely the result of the activity of an independent citizen organization - the Merchants' Club. This was one of the many independent bodies of public-spirited business men who The merchants' had interested themselves in the problems club merchants' of municipal reform, and who were working in harmony with the mayor. As a business proposition, the Merchants' Club was first to recognize the necessity for a thorough and well-adapted system of accounts. Such a method appealed to their practical judgment as the first result to be obtained before any 
sound thinking might be done about present financial condition or future administrative action. This organization, therefore, requested of the mayor permission to have an independent investigation of the city's accounting methods. The request was granted, and a firm of well-known certified public accountants was employed. The preliminary investigation lasted several months, a report being made to the Merchants' Club, March 2I, rgor.

Reporting on accounting methods, the investigation showed (I) that although improvements had been introduced by the administration within the two years preceding, there was still a lack of uniformity and a confusion of Defects in the methods inherited from the past which practisystem of ad- cally made the records of the city unavailable ministration for any administrative purpose; (2) that the accounts with different city departments, as shown on the books of the comptroller in many instances, did not agree with the same accounts on the books kept by the departments themselves; (3) that there was no adequate system of audit and no way of bringing the various accounts into harmony; (4) that the comptroller lacked the authority in many instances to compel a uniform method, and had not adequate power to inspect or audit before authorizing disbursement; (5) that there was such variety in the methods of disbursements as to make auditing and verification of claims difficult, even if adequate authority were given; (6) that in the records of receipts and disbursements, both revenue receipts and the proceeds from loans were accredited to the central funds and subsequently distributed, in such manner that the general accounts in many instances did not furnish an intelligent statement of operating expense as distinct from construction, property, and other permanent accounts; 
(7) that all warrants drawn on the treasurer were paid by him, by means of his own private check, and these were not a part of the public records; (8) that entries such as judgments of valuation were made against the "stock account," or what is sometimes known as "closing" account, thus making statements of current revenues and expenses more uncertain; (9) that the treasurer's special assessment cash-books were frequently destroyed, thus leaving a large amount of trust funds without books of original entry; (Io) that errors and discrepancies of account were adjusted by "posting" a balance without investigation of the errors or discrepancies; (II) that the item "cash," as shown in the general balance sheets rendered, was stated without regard to the funds to which the cash belonged, thus giving a false impression as to available assets; (I2) that the records of disbursements in the comptroller's office were incomplete and defective; (I3) that there was no record in the comptroller's office of compensation in arrears, and no record of departmental materials and supplies; (I4) that no proper record was kept of current or fixed liabilities of the city, and the city had no means of finding out the extent of its present indebtedness.

The report, however, did not stop here. It went into the financial and economic aspects of the situation as well. In reference to the revenue system it was shown Financial and (I) that adequate provision was not made economic as- for meeting the current expenses of the city. pects

In so far as the city relied on taxation for revenue, taxes for the current year were levied on April I, and were not payable until December; - in other words, the current revenues did not anticipate current expenses. In order to utilize taxes assessed but not collected, as available resources, the city was required to borrow in 
anticipation of taxes to be collected during about ten months of the year, and to pay on an average about four per cent for the advances. To further this kind of borrowing, a law had been enacted which allowed the treasurer to issue tax warrants against taxes assessed, but not collected, to the extent of seventy-five per cent of the total amount uncollected. Similar arrangements had been made for meeting expenses of the water department. Water certificates were issued in anticipation of revenue. (2) The taxing bodies had no direct or immediate correlation and did not place the collection of taxes immediately under the supervision of municipal officers. Taxes levied were to be collected by what were known as town collectors - officers elected within the jurisdiction of the old "towns" that had been absorbed by the broader political organization. Delinquent taxes were to be collected by the county treasurer, who was ex-officio county collector. There was no municipal officer, therefore, who had any immediate responsibility for the collection of current revenues in the form of direct taxes. (3) The money when collected had been retained by these town and county officers for their own personal profit. It was shown that although by provision of law they were allowed two per cent on the taxes collected, not to exceed \$I,500 per year, the excess to be turned over to the city treasurer, these officers had regularly retained two per cent on the total amount collected, and, following the established custom, during the preceding five years the city had lost $\$ 280,699$ on this account; that, by reason of the withholding of taxes collected, the city had been required to borrow. money to meet current expenses, while these officers had been obtaining a large revenue in the form of interest on account. It was estimated that the indirect cost to the city through the employment of such methods was very large. 
(4) Another fault in the financial system was found in the losses and depreciation due to taxes written

Faults in the financial system off or uncollected. These losses were allowed on the mere representation of the town or county collector without investigation, audit, or inquiry. Such losses, according to the report of the comptroller, amounted to about $\$ 500,000$ per annum. (5) The comptroller's books of adjustments showed no record such as taxes uncollectible or held in abeyance, nor of taxes in arrears. The collection of franchise taxes was under a separate bureau, and returns of this class were received without question or audit. In two cases it was shown that neither car licenses nor mileage licenses had been collected for five years; the records were incomplete and unreliable. Considerable loss was entailed on these accounts. (6) Special assessments, while under the administrative direction of a local improvement board, because of an inadequate system of accounting, had been a heavy burden to the city. The expenses for interest resulting from withholding the collection of such assessments were shown to be very large. (7) The waterworks and other municipal industries were bureaus of a general department of public works, in which there were no adequate accounting provisions for showing the operations of the public industries. (8) The method of payment of city employees in cash by sending the paymaster's wagon from place to place where men congregated was a waste of time and, therefore, a charge on the city, while the method of paying the police and other regularly employed persons in the service tended to interfere with the duties to which they were assigned. (9) The real estate record was so inaccurate and so poorly kept that the city had allowed many of its rights to lapse, and the city had suffered loss on this account. 
From the report thus submitted it became evident that the first judgment of the members of the Mercharits' Club was fully justified; that the place where municipal reform must begin was with the accounts and financial records of the city; to reduce them to such order as to make the data available as a basis for politiReform in ac-
counts essential report having been laid before the mayor, an ordinance was drafted and passed authorizing Haskins \& Sells, certified public accountants, to install a new system of accounts, and to supervise its operation during the first year after installation.

Detailed consideration of the auditing and accounting difficulties of the city of Chicago prior to the introduction of the new system would be of little purpose, per se. Ours is not a historical interest; our attention is directed to the present and toward the future. A perspective of past conditions is of value only as a background from which we can mark progress. For the present purpose, two questions are before us: (I) Those interested in the general work of the National Municipal League wish to know the extent of the reform accomplished - the progress made by the introduction of a new system of accounts; (2) the Committee on Uniform Accounting are interested in knowing whether the schedules and classification of financial data proposed by them as a basis for scientific and uniform accounting will apply to such a situation as that described. The first is a local question; the second is a general one. The work of the committee has been directed toward the establishment of a common basis for municipal financial records as a first premise for thinking about common problems of administration and enlightened citizenship.

Answering the first question, we turn to the official 
report of the comptroller of the city of Chicago just issued. The features of the new system as there set forth are Features of the
new system as follows: " ( $\mathrm{I}$ ) Uniformity in accounting methods. (2) Concentration of the accounting in the Comptroller's office. (3) Collection of all revenue by the City Collector. (4) Daily remittances. (5) Monthly reports and balances between the Comptroller and all departments. (6) Monthly financial report of the Comptroller. (7) Organization of an Audit Bureau and of a methodical plan of auditing by officers and employees retained specially for that purpose, and independent of all departments. (8) Accruement of revenues on the General Books of the City, where they will always be evident as obligations due the city until paid. (9) Approval of all contracts and requisitions for supplies by the Comptroller, to prevent departments from incurring liabilities in excess of appropriation. (Io) The issuance of all fiscal stationery, forms and receipts, consecutively numbered by the Comptroller, and holding the departments responsible for their use or cancellation. (II) The use of graduated stubs or coupon receipts to check the collection of money. (I2) The establishment of a complete chain of accounting, from the inception of revenue or expense throughout the various branches of the city to the Comptroller's office, where all the accounting is finally centralized.

"The financial operations of the city are summarized in the monthly report compiled in the Comptroller's office not later than the twentieth of each month, for the preceding month. This report shows: (I) Balance Sheet. The financial condition of the city at the end of the month, Monthly re- as compared with the same month of the ports as a fea- previous year, and the resultant increases and ture decreases during the year. The Balance Sheet is so classified as to show the financial condition 
of the municipality in its relation to the City Corporate, the Trust Funds, the Water Works, the Schools and the Library. Schedules supporting the Balance Sheet show the component details of each item contained therein. (2) The Revenue ${ }^{1}$ and Expenses ${ }^{2}$ for the month, compared with the same month of the previous year, and of the elapsed period of the current fiscal year, compared with the corresponding period of the previous year. The Expenditures authorized by the appropriation ordinance remaining unexpended, and the percentage of the appropriations expended. The Revenue, Expenses, and Appropriations are shown in detail, segregated, first, as between City Corporate, the Trust Funds, the Water Works, the Schools and the Library, and, second, between Ordinary Revenue and Expenses and Extraordinary Revenue and Expenses. Ordinary Revenue represents the income from taxation, licenses, fees, etc. Extraordinary Revenue represents income which must be set aside or reserved for special uses such as the building of schoolhouses, the payment of bonds or water certificates, or income which is derived from a decrease in the fixed assets of the city, such as the sale of buildings, lands, etc. Ordinary Expenses represent the amount expended in conducting the City Government, as for salaries and wages and supplies for current operation, maintenance, repairs, operation, etc. Extraordinary Expenses represent the amount expended to increase the fixed assets, such as the purchase of lands, erection of new buildings, construction of additional sewers, the payment of bonds, etc."

The same report also tells us something about the suc-

1 Revenue indicates accruements of revenue renewable accounts pertaining to a fiscal period, whether collected or to be collected.

${ }^{2}$ Expenses indicate the expenses of the city, incurred on account of the period, whether these expenses have been paid or are to be paid. 
cess of this new system during the time that it has been in operation. "All departments of the City Government have been operating thereunder during the past year. The change from the old to the new method was accomplished without confusion or detriment to the conduct of public business, and the detailed workings of the new system have progressed without friction. It is now evident that the system has proved an advantage to the City Government; that it has improved the efficiency of individual employees and promoted an intelligent and interested direction of their efforts by departmental heads." From the point of view of economy, the comptroller also shows that during the past year there has been a reduction in running expenses amounting to $\$ 72,630$, and alludes to this decrease in expense as a permanent economy. The Saving effected savings to various departments of the service brought about through increased efficiency and reduction of clerical force are given in detail, as follows:

Civil Service Commission............ \$3,750.00

Bureau of Local Improvements........ $\quad 3,240.00$

Police Department. ............... $\quad 5,500.00$

Department of Supplies ............ $\quad 1,800.00$

Fire Department ................. $\quad 2,400.00$

City Clerk.................... 5, 5, 100.00

Boiler Inspector.................. $\quad 1,000.00$

Board of Examining Engineers........ 900.00

Comptroller's Office .............. $4,600.00$

City Collector................. 12,440.00

Total Corporate .........

PUblic Library -

Secretary's Office................. \$1,250.00

Reference Department............ $\quad 1,300.00$

Circulating Department........... $\quad 2,560.00$

Total Library ............ $\overline{\$ 5, \text { I 1 } 0.00}$ 
WATER-WORKS -

Water Pipe Extension.............. \$ \$8,000.00

Pumping Stations. .............. $\quad 6,300.00$

Collection Division, Water Office...... $12,500.00$

Total Water-Works ......... $\overline{\$ 26,800.00}$

ReCAPITULATION -

Total Corporate.................\$40,730.00

Total Library.................. $\quad 5,110.00$

Total Water.................. 26,800.00

Total reduction............ $\overline{\$_{72,640.00}}$

Moreover, the mayor, by official acknowledgment, has confirmed the first judgment of the accountants as to the increase in revenue which would be effected Increase in by an efficient system of central control.
revenues

Besides an increase of over $\$ 600,000$ in revenue from direct taxation, there has been an increase in the revenues from various departments of government, as follows:

\begin{tabular}{|c|c|c|c|}
\hline & 1902 & 1901 & Increase \\
\hline Licenses . . . . . . . . . & $\$ 3,770,735 \cdot 37$ & $\$ 3,633$, Or $7 \cdot 73$ & $\$_{137,717.64}$ \\
\hline Police Justice Courts........ & I $10,334.33$ & $98,213.16$ & I 2,12 I.I 7 \\
\hline House of Correction........ & I I I , I O5.96 & $88,303.93$ & $22,802.03$ \\
\hline Police Department........ & I $5,740.42$ & $7,968.84$ & $7,771 \cdot 58$ \\
\hline Public Pounds............ & $2,519.46$ & $1,454.76$ & $1,064 \cdot 70$ \\
\hline Department of Buildings..... & $75,265 \cdot 30$ & 66,3 I 7.85 & $8,947 \cdot 45$ \\
\hline Department of Electricity.... & $5 \mathrm{I}, 904 \cdot 5 \mathrm{I}$ & $27,8 \mathrm{r} 8.95$ & $24,085 \cdot 56$ \\
\hline Department of Public Works & I $27,56.64$ & $98,313.57$ & $29,251.07$ \\
\hline Insurance $\operatorname{Tax} \ldots \ldots \ldots \ldots$ & $158,702.18$ & $151,013.40$ & $7,688.78$ \\
\hline Other $\ldots \ldots \ldots \ldots \ldots \ldots$ & $860,642.64$ & $771,433.00$ & $89,209.64$ \\
\hline Total. . & $\$ 5,284,5$ I $4.8 \mathrm{I}$ & $\$ 4,943,855 \cdot 19$ & $\$ 340,659.62$ \\
\hline
\end{tabular}


The total of decreased expense and increased revenues of the city seems to be close to a million dollars. Without going further into detail more than to refer the reader to the final report, it may be said that, from a point of view of municipal reform, the new system of accounts has laid the foundation for effective administration, and that the reports based on this system give to the citizen a well-classified digest of financial results, supplemented by schedules in sufficient detail to allow the citizen to obtain a comprehensive knowledge of the affairs of the municipality.

Before undertaking a critical examination of the new system for the purposes of the second inquiry, it may be said by way of introduction that, at the time the work of audit and reorganization was begun, our own committee had not yet settled its general accounting programme, nor had we definitely formulated our schedules. Moreover, those in charge of the Chicago operation were required to act promptly, and to recommend to the mayor and council a definite programme for such final action as was necessary to get authority to make needful changes in records and administrative machinery. It was June 24, r9or, when the council authorized the mayor, comptroller, and chairman of the Committee on Finance to engage the services of an independent firm of accountants. On November 20, I90I, Haskins \& Sells submitted a report not only outlining the general system of municipal accounts to be followed, but also furnishing detailed schedules defining the operations of the system The work of in each of the various departments, bureaus, audit and re- and offices of the City Government. The organization details reported went so far as to prescribe all the necessary books, blanks, and reports. In preparing the general outlines of the plan, one member of our committee was brought into advisory relation with the 
certified public accountants in control, one of whom was also a member of your committee; hence the new plan had the direction or advice of two of our members. This report covered 236 printed pages, and included a revision of all ordinances which conflicted with the proposed system and drafts for new ordinances required. On December 23, I90I, the City Council passed an ordinance making the system as shown in their report, "with all accompanying exhibits submitted," the final accounting and auditing system of the city of Chicago.

Another fact must also be taken into account: that, without precedents to guide and to govern, those who had charge of the Chicago operation had to face local conditions which were by practice traditional, and the inertia of a body of administrative agents which stood like an army trained to tactics that they well understood but which the accountants in charge were asking them to discard for new ones. Local traditions, local ordinances and local statutes were to be reckoned with. The new system once inaugurated by ordinance and fortified by practice of a large administrative body must stand as placed until strong reason is again shown for change.

While the schedules of the committee, therefore, have been undergoing constant change, the work at Chicago some two years ago assumed a permanent form, and must be regarded in the light of its creation. It may be further said that the schedules of the committee adopted on January 2, 1903, have been drawn from the accounting experience of members, beginning with small places like Brookline, Massachusetts, and extending locally over other cities, until finally, during the last year under Ohio's code, they have been brought to the test in application to all cities in that populous State. From this varied experience the members of the committee have com- 
pleted their general schedules with reference to municipal revenues, expenditures and appropriations; but the schedules and statements of final condition, as shown in the balance sheet and exhibits ancillary thereto, have not been formally taken up. This part of this work is still in the hands of a sub-committee.

With these explanations, we take up for technical examination the system of accounts introduced into the city of Chicago. Having no balance sheet

Technical examination for comparison, except that which is to be reported by the sub-committee at this session, the one worked out for the city of Chicago seems to have such special value that it is incorporated here:

Corporate Purposes - Comparative General Balance Sheet DECEMBER 3I, IgO2 AND I 9 OI

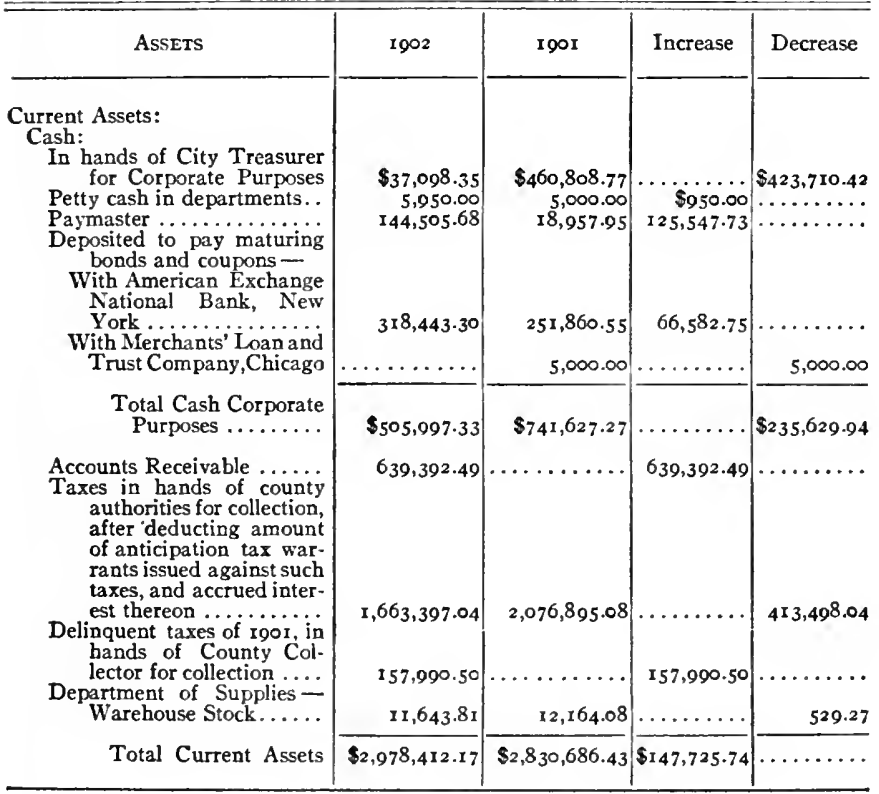


Corporate Purposes - Comparative General Balance Sheet DECEMBER 31, I902 AND IgOI - Continued

\begin{tabular}{|c|c|c|c|c|}
\hline Assets & 1902 & 1901 & Increase & Decrease \\
\hline $\begin{array}{l}\text { Contingent Assets: } \\
\text { Uncollected sewer tax ..... } \\
\text { Norwood Park tax certifi } \\
\text { cates } \ldots \ldots \text {............ } \\
\text { P. Radieski - Shortage.... }\end{array}$ & $\begin{array}{r}\$ 5,345.80 \\
596.78 \\
6,702.84 \\
\end{array}$ & $\begin{array}{r}\$ 5,345.80 \\
596.78 \\
6,702.84\end{array}$ & & $\cdots \cdots \cdots$ \\
\hline $\begin{array}{r}\text { Total Contingent As- } \\
\text { sets } \ldots \ldots \ldots \ldots \ldots \ldots\end{array}$ & \$r $2,645 \cdot 42$ & $\$_{12,645.42}$ & & \\
\hline $\begin{array}{c}\text { Total Current and } \\
\text { Contingent Assets. }\end{array}$ & $\$_{2,991,057.59}$ & $\$_{2,843,331.85}$ & $S_{147,725.74}$ & \\
\hline 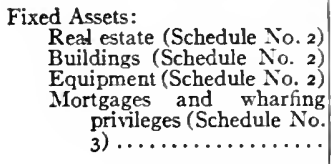 & $\begin{array}{r}\$ 2,265,332.39 \\
4,101,248.25 \\
4,503,312.13\end{array}$ & $\begin{array}{r}\$ 2,119,227.24 \\
4,152,407.40 \\
4,392,036.27\end{array}$ & \begin{tabular}{r}
$\$ 146,105 \cdot 15$ \\
\hdashline$\ldots \ldots \ldots .96$ \\
$111,275.86$
\end{tabular} & $\begin{array}{r}\$ \ldots \ldots \ldots \\
\$ 51,159.15 \\
\cdots \ldots \ldots \ldots\end{array}$ \\
\hline Total Fixed Assets... & Sro,895, 139.8r & $\$ 10,688,917.95$ & $\$ 206,221.86$ & $\ldots \ldots$ \\
\hline $\begin{array}{r}\text { Excess of Deferred Liabilities } \\
\text { and Bonds over Fixed } \\
\text { Assets ............... }\end{array}$ & $9,824,290.01$ & $9,5 \times 2,574 \cdot 46$ & $311,715.55$ & $\cdots$ \\
\hline Total .... & $\$ 20,719,429 \cdot 82$ & $\$ 20,201,492.41$ & $\$ 517,937.41$ & $\cdots$ \\
\hline Grand Total. & $\$ 23,710,487.4 \mathrm{I}$ & $\$ 23,044,824.26$ & $\$ 665,663.15$ & \\
\hline
\end{tabular}

Corporate Purposes - Comparative General Balance Sheet DECEMBER 3I, I9O2 AND I9OI

\begin{tabular}{|c|c|c|c|c|}
\hline LiaBILITIES & 1902 & 1901 & Increase & Decrease \\
\hline 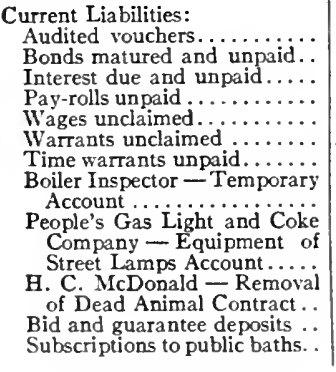 & $\begin{array}{r}\$ 426,945.96 \\
8,600.00 \\
309,843.30 \\
144,505.68 \\
6,155.64 \\
\ldots \ldots \ldots . . . \\
810.33 \\
\\
336 . \infty\end{array}$ & $\begin{array}{r}\text { \$1,119,091.76 } \\
19,700.00 \\
237,160.55 \\
18,957.95 \\
6,254.19 \\
331.53 \\
810.33 \\
\\
336.00\end{array}$ & $\begin{array}{l}\ldots \ldots \ldots \\
\$_{72,682.75} \\
125,547.73 \\
\ldots \ldots \ldots \ldots \\
\ldots \ldots \ldots \ldots\end{array}$ & $\begin{array}{r}\$ 692,145.80 \\
11,100.00 \\
\ldots \ldots \ldots \ldots \\
\cdots \ldots . \\
98.55 \\
331.53 \\
\ldots . \cdots \cdots \\
\ldots \ldots \ldots \ldots \\
\\
85.00 \\
1,000.00 \\
9,515.55 \\
\ldots \ldots \ldots\end{array}$ \\
\hline
\end{tabular}


Corporate Purposes - Comparative General Balance Sheet DeCEMBER 31, I902 AND 1901 - Continued

\begin{tabular}{|c|c|c|c|c|}
\hline Liabil ITIES & 1902 & I9OI & Increase & Decrease \\
\hline Vehicle and bicycle tax repay- & & & & \\
\hline 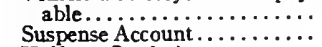 & $\begin{array}{r}\$ 733.50 \\
25,179.44\end{array}$ & $\begin{array}{r}\$ 734.25 \\
26,744.25\end{array}$ & & $\begin{array}{r}\$ .75 \\
I, 564.8 \mathrm{I}\end{array}$ \\
\hline Uniform Stock Account....... & 402.88 & 508.46 & & 105.58 \\
\hline $\begin{array}{l}\text { City Employees' Transporta- } \\
\text { tion Account .............. }\end{array}$ & $6,696.70$ & 275.92 & $\$ 6,420.78$ & \\
\hline $\begin{array}{l}\text { Judgments and costs, appro- } \\
\text { priated for ............... }\end{array}$ & $14,248.98$ & $24,380.44$ & & $10,135.46$ \\
\hline Reserve for cost and deficiency & & & & 20,13040 \\
\hline $\begin{array}{l}\text { in the collection of taxes ... } \\
\text { Reserve for uncompleted con- }\end{array}$ & $240,243.0 \mathrm{r}$ & $I 74,335 \cdot 59$ & $65,907 \cdot 42$ & $\cdots$ \\
\hline $\begin{array}{l}\text { tracts and unexpended ap- } \\
\text { propriations of } 1902 \text { (Sched- } \\
\text { ule No. } \mathrm{r}) \ldots \ldots \ldots \ldots \ldots \ldots\end{array}$ & $225,163.8 \mathrm{I}$ & & $225,163.8 \mathrm{r}$ & \\
\hline Reserve for doubtful accounts & $43,467.59$ & $\ldots \ldots \ldots \ldots$ & $43,467 \cdot 59$ & \\
\hline $\begin{array}{c}\text { Total Current Liabili- } \\
\text { ties } \ldots \ldots \ldots \ldots \ldots \ldots\end{array}$ & \$I, 457,954.00 & $\$ r, 644,842.95$ & & $\$ 186,888.95$ \\
\hline $\begin{array}{c}\text { Excess of Current and Contin- } \\
\text { gent Assets over Current } \\
\text { Liabilities............... }\end{array}$ & $\mathrm{I}, 533,103.59$ & $\mathrm{I}, \mathrm{I} 98,488.90$ & $\$ 334,6 I_{4} .69$ & \\
\hline Total ............ & $\$ 2,991,057.59$ & $\$ 2,843,331.85$ & $\$ 147,725.74$ &.. \\
\hline Deferred Liabilities: & & & & \\
\hline $\begin{array}{l}\text { City of Chicago - Trust Funds } \\
\text { Account ................... }\end{array}$ & $\$ 1,383,232.53$ & $\$ 1,183,682.83$ & & \\
\hline Judgments............... & 4,2 I $3,197.29$ & $3,547,809 \cdot 58$ & $665,387.71$ & \\
\hline $\begin{array}{c}\text { Total Deferred Lia- } \\
\text { bilities ........... }\end{array}$ & $\$ 5,596,429.82$ & $\$ 4,73 \mathrm{I}, 492.4 \mathrm{I}$ & $\$ 864,937.4 \mathrm{I}$ & \\
\hline City of Chicago Bonds: & & & & \\
\hline Municipal $\ldots \ldots \ldots \ldots \ldots \ldots$ & $835,000.00$ & $835, \infty 00 . \infty$ & & $\ldots \ldots$ \\
\hline $\begin{array}{l}\text { Tunnel....................... } \\
\text { Sewerage Loan......... }\end{array}$ & $\begin{array}{r}496,000.00 \\
2,124,500.00\end{array}$ & $\begin{array}{r}496,000.00 \\
2,124,500.00\end{array}$ & & \\
\hline River Improvement .......... & $2,605,500.00$ & $2,605,500.00$ & & \\
\hline School $\ldots \ldots \ldots \ldots \ldots \ldots$ & $895,000.00$ & $895,000.00$ & & \\
\hline Village of Rogers Park ...... & $7,000.00$ & $7,000.00$ & & \\
\hline $\begin{array}{l}\text { Water } \ldots \ldots \ldots \ldots \ldots \\
\text { World's Fair Bonds }\end{array}$ & $3,643,000.00$ & $3,990, \infty 00 . \infty 0$ & & $\$ 347,000,00$ \\
\hline World's Fair Bonds............. & $4,517,000.00$ & $4,517,000.00$ & $\cdots$ & \\
\hline $\begin{array}{l}\text { Total Bonds (Sched- } \\
\text { ule No. 4) }\end{array}$ & $\$ 1_{5}, 123,000.00$ & $\$ 15,470,000.00$ & & $\$ 347,000.00$ \\
\hline $\begin{array}{l}\text { Total Deferred Lia- } \\
\text { bilities and Bonds.. }\end{array}$ & $\$ 20,719,429.82$ & $\$ 20,201,492.4 \mathrm{I}$ & $\$ 5 I 7,937.4 I$ & . \\
\hline Grand Total.... & $\$ 23,710,487.41$ & $\$ 23,044,824.26$ & $\$ 665,663.15$ & \\
\hline
\end{tabular}

Referring to these, several items may be mentioned: (I) Attention is called to the title "cash" under current assets which, it is to be noted, is subdivided to show the 
several departments or funds to which the cash belongs; (2) the last item under current assets, "department of supplies - warehouse stock" may be open to question. Technical objection may possibly be raised as to whether or not warehouse stock is to be considered a current asset, against which current liabilities may be set off; (3) it is to be noted that under the heading "contingent assets," the items are set up in detail; (4) another The balance sheet important feature is found under the titie "fixed assets," from which it appears that complete supplementary schedules of "real estate," "buildings," "equipment," and "mortgages" are made a part of the report. These schedules, under the ordinance, are required and serve as inventories of municipal properties, which are published for the information of the people.

On the liabilities side of the balance sheet it is to be noted (I) that the current liabilities are minutely classified; (2) that reserves have been set up against current assets - (a) "for cost and deficiency in collection of taxes; (b) for uncompleted contracts and unexpended appropriations of I9O2; (c) for doubtful accounts;" it further appears that the second reserve referred to is itemized on pages 48 and 49 of the Report of the Comptroller, and the schedule there found is one of the forms prescribed under the new system adopted by the city; (3) under the heading "deferred liabilities" are found all of the over-drafts on "trust funds" and "judgments" for which the city is liable; (4) the bonded debt of the city is set out in full and classified and further illuminated by schedule, which is also a required form; (5) the surplus account is also fully illuminated by schedule. Looking to the balance sheet as a whole, it conforms to the best canons of accounting, and is in thorough alignment with the work of the committee, so far as it has gone. 
It is here set forth for the purposes of comparison with the balance sheet used in Ohio and in other operations to be reported by others at this session.

The schedules of the Committee on Uniform Municipal Accounts, adopted January 2 last, reduce revenues, expenditures, and appropriations to the same basis of general classification. The report of Mr. Chase on the schedules adopted by Ohio as a basis for uniform municipal accounting in that State shows the same classification. In adopting the schedules for the city of Chicago this uniformity of classification is not observed. The "revenues," "expenses," and "expenditures authorized by appropriation ordinances" each have a separate groupClassification ing. Revenues are divided into (I) taxes, of revenue (2) licenses, and (3) miscellaneous. Under accounts what is called miscellaneous revenue, however, the various departments of government are set out in detail, so that the several items and summaries may be redistributed under the classification proposed by your committee for purposes of comparative study:

Miscellaneous Revenue-Corporate Purposes by Departments and Months - Year Ended December 3r, 1902

\begin{tabular}{|c|c|}
\hline $\begin{array}{c}\text { Dept. } \\
\text { No. }\end{array}$ & Account \\
\hline ० & Mayor's Office - Auctioneers, Permits ....... \\
\hline I & City Clerk - Miscellaneous............ \\
\hline 2 & Corporation Counsel's Office... \\
\hline 3 & Prosecuting Attorney's Office........ \\
\hline 4 & City Attorney's Office $\ldots \ldots \ldots \ldots \ldots \ldots \ldots$ \\
\hline 5 & Department of Finance - Comptroller's Office... \\
\hline 6 & Finance Department - City Treasurer .......... \\
\hline 8 & Finance Department - Miscellaneous ......... \\
\hline $9 \mathrm{~A}$ & $\begin{array}{l}\text { Police Department }- \text { Special Details and Appoint- } \\
\text { ments } \ldots \ldots \ldots \ldots \ldots \ldots \ldots \ldots \ldots \ldots \ldots \ldots\end{array}$ \\
\hline
\end{tabular}


Miscellaneous Revenue - Corporate Purposes by Departments And Months - Year Ended Decesiber 3I, I902 - Continued

\begin{tabular}{|c|c|}
\hline $\begin{array}{c}\text { Dept. } \\
\text { No. }\end{array}$ & Account \\
\hline $9 \mathrm{C}$ & Police Department - Miscellaneous.......... \\
\hline $10 \mathrm{~A}$ & Police Justice Courts - Fines and Forfeitures... \\
\hline IO B & Police Justice Courts - Miscellaneous.......... \\
\hline II $\mathrm{A}$ & 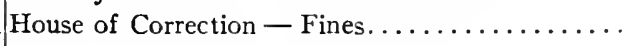 \\
\hline II $\mathrm{B}$ & House of Correction - Sale of Produce....... \\
\hline II $\mathrm{C}$ & House of Correction - Laundry Work ..... \\
\hline II $\mathrm{D}$ & House of Correction - Boarding Prisoners... \\
\hline II $\mathrm{E}$ & House of Correction - Miscellaneous....... \\
\hline $13 \mathrm{~A}$ & Public Pounds - Dogs ................. \\
\hline $13 \mathrm{~B}$ & Public Pounds - Other............... \\
\hline 14 & Fire Department.................. \\
\hline $15 \mathrm{~A}$ & Department of Buildings - Permits.... \\
\hline$I_{5} \mathrm{~B}$ & Department of Buildings - Inspection . \\
\hline $16 \mathrm{~A}$ & Health Department - Inspection ..... \\
\hline $16 \mathrm{C}$ & Health Department - Miscellaneous ...... \\
\hline $17 \mathrm{~B}$ & 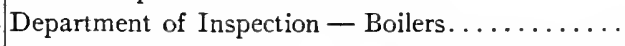 \\
\hline $17 \mathrm{D}$ & Department of Inspection - IVeights and Measures \\
\hline I7 $\mathrm{E}$ & 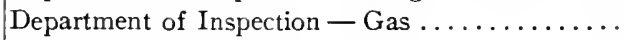 \\
\hline $17 \mathrm{~F}$ & 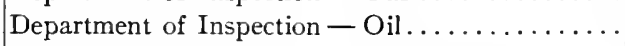 \\
\hline $17 \mathrm{G}$ & Department of Inspection - Automobiles........ \\
\hline I $7 \mathrm{I}$ & Department of Inspection - Miscellaneous....... \\
\hline I9 A & Department of Public Works - Map Fees...... \\
\hline I9 C & 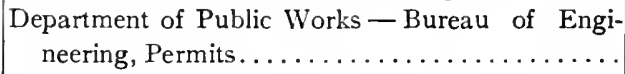 \\
\hline I9 E & $\begin{array}{l}\text { Department of Public Works - Bureau of Engi- } \\
\text { neering, Bridges and Viaducts } \ldots \ldots \ldots \ldots \ldots\end{array}$ \\
\hline I9 $\mathrm{F}$ & 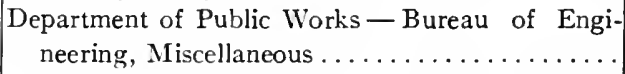 \\
\hline $19 \mathrm{G}$ & $\begin{array}{c}\text { Department of Public Works - Bureau of Streets, } \\
\text { Permits } \ldots \ldots \ldots\end{array}$ \\
\hline $19 \mathrm{H}$ & 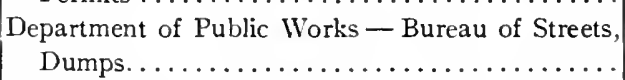 \\
\hline I9 I & 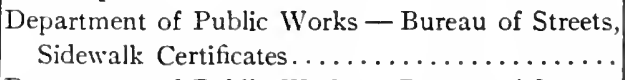 \\
\hline $19 \mathrm{~K}$ & $\begin{array}{c}\text { Department of Public Works - Bureau of Streets, } \\
\text { Miscellaneous......................... }\end{array}$ \\
\hline
\end{tabular}


Miscellaneous Revenue - Corporate Purposes by Departanents AND Months - Year ENDEd DeCEMber 31, 1902 - Continued

\begin{tabular}{|c|c|}
\hline $\begin{array}{c}\text { Dept. } \\
\text { No. }\end{array}$ & AccounT \\
\hline I9 L & Department of Public Works - Bureau of Sewers, \\
\hline & Permits...$\ldots \ldots \ldots \ldots \ldots \ldots \ldots \ldots \ldots \ldots \ldots \ldots \ldots$ \\
\hline I9 $\mathrm{N}$ & Department of Public Works - Bureau of Sewers, \\
\hline & 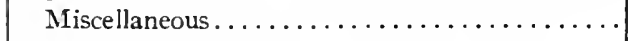 \\
\hline $20 \mathrm{~A}$ & Department of Electricity - Sale of Power ....... \\
\hline $20 \mathrm{~B}$ & Department of Electricity - Permits........... \\
\hline $20 \mathrm{C}$ & Department of Electricity - Inspection.......... \\
\hline $20 \mathrm{D}$ & Department of Electricity - Miscellaneous....... \\
\hline 2I A & $\begin{array}{l}\text { City Real Estate and Buildings }- \text { Rents and Com- } \\
\text { pensation } \ldots \ldots \ldots \ldots \ldots \ldots \ldots \ldots \ldots \ldots \ldots \ldots \ldots\end{array}$ \\
\hline 2I B & City Real Estate and Buildings - Miscellaneous. . \\
\hline $23 \mathrm{~A}$ & Licenses - Saloon (Statement "A")............. \\
\hline $23 \mathrm{~B}$ & Licenses - Other (Statement "A") ........ \\
\hline $24^{*}$ & 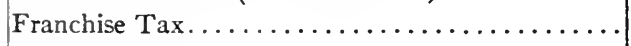 \\
\hline 25 & Insurance $\operatorname{Tax} \ldots \ldots \ldots \ldots \ldots \ldots \ldots \ldots \ldots \ldots \ldots$ \\
\hline 30 & 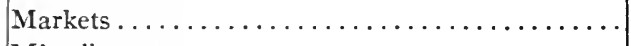 \\
\hline $3 \mathrm{I}$ & 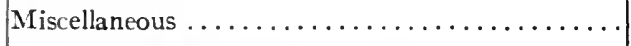 \\
\hline & Gross Miscellaneous Revenue ............ \\
\hline & Deductions from Miscellaneous Revenue \\
\hline $\mathrm{roA} \dagger$ & Police Court - Fines and Forfeitures .......... \\
\hline I 4 & $\begin{array}{c}\text { Fire Department }- \text { Paid to Firemen's Pension } \\
\text { Fund } \ldots \ldots \ldots \ldots \ldots \ldots \ldots \ldots \ldots \ldots \ldots \ldots\end{array}$ \\
\hline I $7 \mathrm{~B}$ & Department of Inspection - Boilers - Expense .. \\
\hline I7 G & $\begin{array}{r}\text { Department of Inspection }- \text { Automobiles }- \text { Ex } \\
\text { pense } \ldots \ldots \ldots\end{array}$ \\
\hline $23 \mathrm{~A}$ & Licenses - Saloons - Paid to Pension Fund..... \\
\hline $23 \mathrm{~B}$ & Licenses - Other - Paid to Pension Fund ...... \\
\hline 25 & $\begin{array}{r}\text { Two Per Cent Insurance Tax }- \text { Paid to Firemen's } \\
\text { Pension Fund } \ldots \ldots \ldots \ldots \ldots \ldots \ldots \ldots \ldots \ldots \ldots\end{array}$ \\
\hline 30 & Markets - Expense of Dayton Street Market.... \\
\hline & 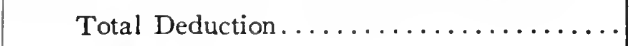 \\
\hline & Net Miscellaneous Revenue............. \\
\hline
\end{tabular}

* Includes unpaid warrant for collection against the People's Gas Light and Coke Co. amounting to $\$ 375,000$.

† Paid to Erring Women's Refuge, House of the Good Shepherd, Illinois Humane Society and the Police Pension Fund. 
Licenses are also classified. The city of Chicago has a more thorough and exhaustive statement than is found in the committee's report.

\section{Licenses Issued by Months and Classes}

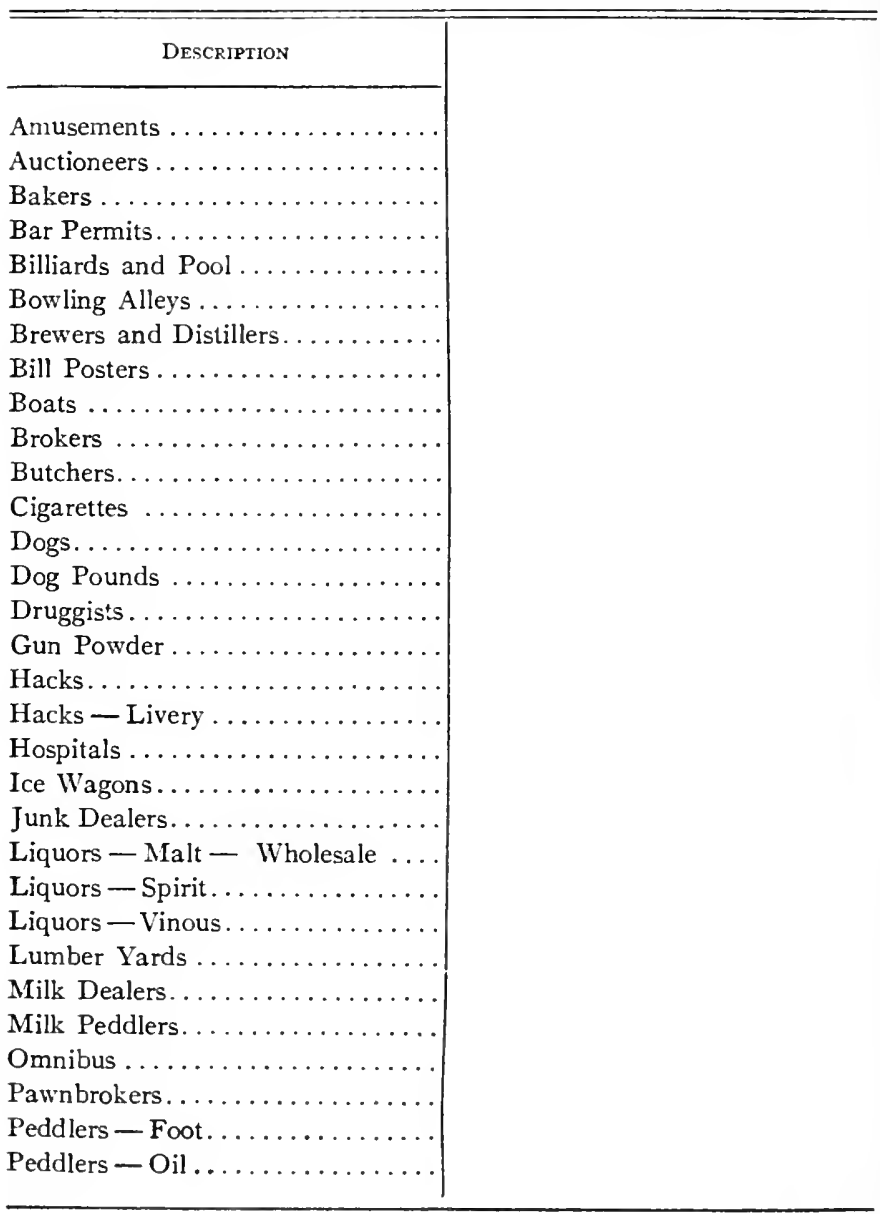


Licenses Issued by Months and Classes - Continued

DESCRIPTION

Peddlers - Wagon

Peddlers - Wood

Real Estate

Rendering

Roofers.

Runners .

Saloons.

Scales - Public

Scavengers.

Second-hand Dealers

Shooting Galleries

Smoked Meats

Soap Factories

Street Cars

Tanneries

Undertakers

Wagons - Junk. .

Wagons - One-horse

Wagons - Two-horse

The schedule of expenses for the city of Chicago is arranged as follows:

I. Corporate Purposes -

I. General government, including executive, legislative and administrative departments.

2. Public Safety, including police and fire departments, hospitals, police courts, prisons, reformatories, etc.

3. Public Works, including streets, sewers, and all works except the water-works.

4. Public recreation and art.

5. Miscellaneous.

II. WATER-Works - Taken out of the department of "Public Works" by the adoption of the new system.

III. Education - Made a separate department by law.

IV. LIBRARY - Also on a separate financial foundation. 
Separate schedules are given for "ordinary" and "extraordinary," showing expenses under each class. Classification By comparing these schedules with those of expense accounts prepared by the Committee on Uniform Municipal Acccounting, it will be found that the outline of Chicago's accounts has a quite different distribution under general titles, but that in nearly every case the sub-titles may be so arranged as to conform almost exactly to the plan adopted at our last meeting. In Chicago, the electric light plant is retained under the general department of "Public Works" for legal and local reasons - this being comparatively unimportant, and the service being organized by law under this department. For like reason it will be found that the "fire and police telegraph" is retained under the department of electricity, although it is set up as a separate title; this may be reclassified, and, for comparison, taken out and put under the class suggested by the committee. No division is made in the new Chicago plan, in the general classification between "protection to life, health, and property" and "public charities and corrections." Special sub-classification, however, is so thoroughly preserved that the various summaries may be reclassified under the committee's outlines. On the subject of "appropriation and expenditure," the budgetary arrangements of Chicago are such that appropriations lapse at the expiration of each year, and the exhibit, as set forth in the new system, seems to be needed in Chicago, a wholesome sliggestion for other cities to follow.

Taking the new system of accounting adopted by the city of Chicago, as a whole, it is a masterly piece of work, and will serve as a milestone in the movement toward municipal reform. To those interested in better government, it may be said that Chicago has taken an advanced 


\section{CHICAGO'S ACCOUNTING REFORM}

position worthy of emulation by other large municipalities. Conclusion

To those who are interested in municipal accounting as a science, it is encouraging to find that the schedules adopted by the city of Chicago, while conforming to legal and local requirements, are so nearly in harmony with those in use by Ohio under its new code and by the various municipalities that have undertaken new systems of accounting. 


\section{CHAPTER XVI}

The System of Accounts and Statistics of the City OF NEW YORK ${ }^{1}$

Staring the purposes for which the Advisory Commission on Finance and Taxation was appointed, the The purposes mayor requested (I) an examination into of the investi- the financial methods of the city and (2) gation that a plan be reported for improving them. More specially, the commission was asked to report a plan looking toward "the reorganization of the city's method of keeping and stating accounts."

Following the lines of the first request a detailed examination was made of the administration and accounting methods employed in five departments, viz.: (I) The Department of Finance, (2) the Department of Docks and Ferries, (3) the Department of Street Cleaning, (4) Bellevue and Allied Hospitals, and (5) the Board of Education.

In selecting these departments the aim was to take those which were typical - the first being the department of general financial control, the second beDepartments examined ing in the nature of a municipal industry, the third, a branch of general administration with an incidental revenue, the fourth having its

${ }^{1}$ Report to the Sub-Committee on Accounting and Statistics of the Mayor's Advisory Commission on Finance and Taxation, appointed by Mayor McClellan, January, 1906, the draft of which was prepared by the chairman. 
expenses and operations controlled by an independent board, the fifth, an administrative unit, organized as a separate corporation entitled to a distinct revenue and having control over the properties used as well as over expenditures and operation.

A detailed description of methods of conducting business and of accounting in the first four of the departments

Detailed reports on method referred to is submitted. The system employed in the Board of Education was examined in detail, but, for reasons later given, only the conclusion reached and a general discussion of the administrative needs of the department are herewith presented (Chapter XVII).

\section{GENERAL CRITICISM OF THE SYSTEM}

The administrative purpose of accounts and statistics being that of obtaining intelligent control over the Administrative activities of an institution, the nature of the purpose of accounts and statistics to be kept must accounts and depend on the different forms of adminisstatistics trative control to be exercised and on the nature of the information needed by those in responsible position, for the exercise of official discretion and for rendering a report of their stewardship. Under the charter of greater New York there are essentially two forms of administrative control to be exercised, viz.: (I) Financial Control and (2) Executive or Operative Control.

The organization within the corporation for the exer-

Charter provisions for financial control

office or division for the collection of revenue, for the exercise of accounting control, and for 
the issue of and account for bonds and obligations of the city, at the head of which is the comptroller; (2) the City 'Treasury, at the head of which is the city chamberlain; (3) Trustees for the selection and approval of depositories of the funds of the city, composed of the mayor, the comptroller, and the chamberlain; (4) Commissioners of the Sinking Fund, composed of the mayor, the comptroller, the chamberlain, the president of the Board of Aldermen, and the chairman of the Finance Committee of the Board of Aldermen; and (5) the Board of Estimate and Apportionment, composed of the mayor, the comptroller, the president of the Board of Aldermen, and the presidents of the boroughs of Manhattan, Brooklyn, Bronx, Queens, and Richmond.

The executive power of the city is located in the mayor and heads of departments. Executive control is provided for through the independent election of a mayor and through a form of corporate organization which gives the mayor the power to "appoint the heads of departments and all commissions, except as otherwise provided," and to "appoint all members of any board or commission authorized to superintend the erection or Charter pro- repair of any building belonging to or to be visions for ex- paid for by the City" ( $\$$ II8). In last ecutive control analysis, responsibility for the character of executive control exercised lies with the mayor. Section 95 provides: "The Mayor may, whenever in his judgment the public interests shall so require, remove from office any public officer holding office by appointment from a Mayor of The City of New York, except members of the Board of Education, and Aqueduct Commissioners, Trustees of the College of The City of New York, and Trustees of Bellevue and Allied Hospitals, and except also judicial officers for whose removal other provision is 
made by the Constitution." Having reference to the exercise of control, it is made the duty of the mayor (Section II5 of the city charter): (I) "to keep himself informed of the doings of the several departments"; (2) "to communicate to the Board of Aldermen, at least once in each year, a general statement of the finances, government and improvements of the City"; (3) "to recommend to the Board of Aldermen all such measures as he shall deem expedient"; (4) "to be vigilant and active in causing the ordinances of the City and the laws of the State to be executed and enforced," and for that purpose it is provided that he may "call together for consultation and coöperation any or all of the heads of departments."

The system of accounting needed by the city as a means of exercising the control contemplated by the charter of organization should provide for accurate and complete knowledge with respect to: (1) the audit and account of revenues accrued as well as revenues collected, and rev-

System of accounts needed for financial control

enues in arrears; (2) the audit of all claims against the city growing out of expenses of current operations as well as capital outlays; (3) a complete and accurate record of bonds and other corporate issues and obligations by the city, together with such information pertaining to the city debt as will enable the comptroller and the Board of Estimate and Apportionment to know when the legal limit of indebtedness is reached; (4) complete and accurate records of receipts and disbursements by funds and appropriations as a means of protecting the fidelity of those entrusted with the keeping of the public funds and the authorized disbursement of the same; (5) a record or list of transactions by depositories, for the information of the trustees for the selection of depositories; (6) a full and true account of the sinking fund to protect the fidelity 
of the Commissioners of the Sinking Fund and as a means of enabling them to exercise the discretion required of this office; (7) such a record and report of operative needs, operative expenses, capital needs, and capital outlays in the departments as will enable the Board of Estimate and Apportionment to exercise intelligent judgment with respect to the apportionment and appropriation of the revenues of the city to the several administrative purposes; (8) such general controlling accounts giving readily and accurately and clearly an intelligent view of the city's true financial position, in order that the public may have a basis for investment judgment and thus enabling the city to dispose of its bonds and corporate stock to the highest advantage.

DEFECTS IN THE SYSTEM OF ACCOUNTS LOOKING TOWARD FINANCIAL CONTROL

Examining the accounts of the city of New York for information necessary to financial control, the first defect to be noted pertains to control over revenue. In the

An imperfect account of revenue accruals first place the controlling accounts of the city only imperfectly take cognizance of revenue accruals, i.e., the taxes and other revenues accrued are not set up in the general accounts as assets, but are taken up on the basis of collections. The result is, that neither officers of financial control, nor the city's creditors, nor the people, have before them an accurate current account of revenues uncollected. In the accounts of the city chamberlain there may be kept a true statement of revenue receipts by sources and a distribution of these to the proper funds. It is unnecessary to duplicate these. The need for revenue accounts in the office of the comptroller is for control. But financial control must be to 
small purpose unless the eye of the comptroller is kept on revenue assets still to be realized. This supervision is important in order that there may be prompt and correct report of the amount of current revenue assets overdue; the amount of each class in the hands of the city marshal for collection and the period to which they belong; the amount of each class in the hands of the Law Department for collection and the periods to which they belong; the amounts of each class in the hands of the Bureau of Assessments and Arrears and the periods to which they belong; the amount of each class of revenue assets realized on by execution and sale and the period to which these assets belong; their present value; and the amount of each class of revenue loss each year on account of failure to collect. All of this information is proper subject of controlling account and current monthly report from the general books of the city.

In this relation it is to be noted that there is no uniform system of accounts of Assessments and Arrears, the accounts of the boroughs examined (Manhattan and Brooklyn) being on a different basis. Of these, the books of the Borough of Brooklyn were in the better condition, Revenue books some of those of the Borough of Manhattan not in control not having been balanced since I898. In and not cur- the department of water supply, the books rently balanced

of ledger account with consumers have never been balanced. The city relies on a system of occasional check on the entries in books representing millions of assets of the city, as a result of which it is possible for entries to be made relieving charges on property, or for payments to be made, without proper account, and for such mistake or fraud to go undiscovered for such time as to hold out a constant inducement to civil servants having access to the books to become dishonest. 
Moreover, the accounts representing special assessments are opened and closed without knowledge on the part of the comptroller's office as to the actual condition of the special assessment with which the account is kept. At times the account is closed before the collections are made, in other instances it remains open after assessments have been realized on.

Reserving criticism on the classification of expenditures (accepting the system in vogue), it is to be observed that there is a multiplication of records of expenditure which is not only unnecessary and useless but which is confusing and expensive. The present basis of expenditure accounting is "funds and appropriations." The information obtained from such accounts is primarily of use in obtaining financial control over the treasury, and for the guidance of the Board of Estimate and Apportionment in making comparison of actual expenditures with amounts apportioned. Instead of satisfying the demand for this inforMultiplication mation through the accounts of the treasury of records of and through an accounting control in the expenditures office of the comptroller, this "fund accounting" extends from the treasury through the office of the comptroller to the departments - fund accounts being thereby kept in triplicate and in some instances in quadruplicate and even greater multiplicity. From the point of view of results obtained, a large part of the work of the present clerical staff in the department is therefore unnecessary. A notable instance of this purposeless restatement of the same facts and of the useless waste of effort in accounting with funds and appropriations is found in the books of account of Bellevue and Allied Hospitals. Aside from the distribution of the expenditures of the department on the books of the treasurer to the proper fund and appropriations, and in like manner 
on the accounts of the comptroller, they are distributed five times to the same appropriation accounts on the books of the department.

From the point of view of accounting control, the defect of multiplication is not as serious as the lack of accounts through which information may be obtained currently for the financial control to be exercised by the Board of Failure to pro- Estimate and Apportionment. This imvide accounts and statistics needed by board of estimate and apportionment portant body has before it very inadequate information for the intelligent discharge of its duties. The character of the accounts and statistics necessary for good judgment as to operative needs and capital outlays in the several departments and divisions of municipal service will be commented on later in detail. But in this relation it may be said that the effect of this lack of intelligence in the work of the board is that appropriations are commonly based on custom and practice or on an apportionment which looks to past expenditures rather than to present or future needs, and this too without any adequate knowledge as to whether past expenditures have been either wisely or economically made.

Attention was recently called to the condition of the

Defects in the general books and controlling widely quoted public address. The records financial ac- kept for giving information to creditors
counts president of the National City Bank in a general accounts of the city by the viceand to the people are characterized as "not much short of chaotic."

It was pointed out that the balance sheet was a misnomer; that reports and financial statements were unintelligible; that even with such few changes as had been made since the greater city was incorporated, creditors and other persons interested in the affairs of the city 
were left to grope in darkness for information necessary to an intelligent opinion as to the value of large issues of securities. When such conclusions are reached by persons who have the best of facilities for inquiring into the conditions of the city's accounts small hope remains for the average citizen, or even for the officers themselves to act with enlightened discretion.

Aside from the defects of system above referred to, it is stated by those in official position that there are several hundred accounts in the general and subsidiary books concerning whose meaning the city's accountants themselves have little or no knowledge. Some of these represent balances of millions of dollars. We are informed

Old accounts not analyzed by one of the accountants in the service of the city that there are upwards of two hundred such accounts on the general ledgers. These are balances inherited from preconsolidation times that have never been analyzed.

DEFECTS IN THE SYSTEM OF ACCOUNTS AND STATISTICS VIEWED IN THEIR RELATION TO EXECUTIVE OR OPERATIVE CONTROL

With powers of appointment and removal of heads of departments, the mayor is responsible to the people for the economy and efficiency with which each department is managed. If the mayor is to live up to the duties and responsibilities placed upon him, there must be a system of accounts and coördinate operative statistics which will keep before him the information necessary to the exercise of mature directive and executive discretion - in other words, as enjoined by Section II 5 of the charter, a system adequate "to keep himself informed of the doings of the several departments." ,

To the end that he may "keep himself informed of the 
doings of the several departments," the mayor is emDuty of mayor powered and required by law (Section II9) to keep him- to "appoint and remove at pleasure two self informed persons who shall be Commissioners of Accounts," who shall "make such special examinations of the accounts and methods of the departments and offices of the City ... as the Mayor may from time to time direct, and such other examinations as the said commissioners may deem for the best interests of the City, and report to the Mayor and the Board of Aldermen the results thereof." For the purpose of ascertaining the facts in connection with these examinations, the Commissioners of Accounts have been given full power to compel the attendance of witnesses, to administer oaths, and to examine such persons as they may deem necessary.

The office of the Commissioners of Accounts, as created by law and developed by the city, operates in a double capacity, viz.: (I) that of an audit bureau which may serve as an executive check on the comptroller, and (2) that of a bureau of statistics for the gathering of data desired by the executive in the exercise of his duties. In this latter capacity the office of Commissioners of Accounts Inadequacy of is practically helpless. Without a complete office of com- and unified system of administrative acmissioners of counts and statistics in the department, Accounts information required for intelligent executive judgment "as to the doings of the scveral departments" may not be currently obtained and reported. Adequate provision for obtaining data necessary to the exercise of judgment in the executive direction of the heads of departments on the part of the mayor would require that the Commissioners of Accounts have a staff approximately as large as the present accounting staff of 
the city. In other words, in an enterprise as large as the city of New York and having such a volume of current transactions, a bureau of statistics is of little value for furnishing current data except as the data are first collected and classified in the departments and divisions of origination.

To duplicate the present accounting staff would be quite as unnecessary as the present office of Commissioners of Accounts is impotent. Section I49 of the charter provides: "The Comptroller shall furnish to each head of department, monthly, a statement

Methods by which a complete administrative accounting may be obtained of the unexpended balances of the appropriation for this department." There being a complete and accurate system of accounts with appropriations in the office of comptroller, by confining the fund and appropriation accounts to the Finance Department, where it is needed for financial control, this would leave the departments free to do the detailed accounting and to keep up the current statistics necessary to furnish a complete digest of the results of operation - the information needful to the head of the department as a means of controlling administrative details, to the mayor that he may "keep himself informed" of the doings of the departments, and (by way of published reports) to the public that an intelligent riew may be had as to the economy of operation and the efficiency of the service supported by public taxation and other forms of public contribution. To state the transactions in the form of controlled accounts would in many instances require less clerical work than at present, where the work is done for statistical purposes and the accounts kept on the fund basis. A notable instance of the duplication of work without obtaining administrative accounting results is found in the Depart- 
ment of Street Cleaning, comments on which may be found in another portion of this address.

Control over administrative accounts may be obtained in one of two ways: (I) through the office of comptroller by the introduction of a uniform system of administrative How operative accounts in the departments under the accounts may powers given to comptroller in Section I49, be controlled making these department accounts subsidiary to general accounts kept in the Department of Finance, or (2) by an amendment of the charter in such manner as to make the Commissioners of Accounts the head of the administrative accounting system and the accounts of the departments subsidiary to this control. In either case, however, it would require that a complete system of accounts be devised and installed in the departments looking toward executive and operative control, leaving the fund and appropriation accounting to the Department of Finance.

The advantage of having the accounts and statistics, which look toward executive or operative control, devised, installed, and supervised by the Commissioners of Accounts would be that the commissioners are appointed by and are responsible to the mayor, for whose information (as

Advantages and disadvantages of each form of control well as that of his subordinates, the heads of departments), the data are to be obtained. Should the commissioners be given accounting functions, the disadvantage of such a control would lie in the possible conflict of authority between the commissioners and the comptroller, and in the possible increased expense. The advantage of having the operative accounts and statistics controlled in the Department of Finance would be that all of the accounts and statistics would thus be brought together in a central office. A possible disadvantage, however, 
lies in the fact that the comptroller is by law made one of the principal officers of financial control, and his administrative responsibilities under the charter have been entirely of this character. As such officer it is incumbent on him to devise and install a system of controlling financial account, but having no responsibility for the economy or efficiency of departments, being independent of the mayor, there has been no provision in the charter making it his duty to devise, install, or control executive and operative accounts.

By reason of this fact, the mayor, in the past, has been seriously handicapped, the interests of the comptroller being financial, not operative; "the forms for keeping and rendering the accounts" have been principally for his information. Nor has the mayor the power to compel the keeping of such departmental accounts as will supply the data necessary to the intelligent performance of his Mayor handi- own duties. As a result the mayor as chaircapped by present charter provisions man of the Board of Estimate and Apportionment, and in passing on the acts of the Board of Aldermen while sitting on the Budget, has been subordinate in the power of exercising intelligent judgment to the comptroller; as the chief executive of departments he has been dependent for current information on one who has no official interest in or responsibility for departmental results; he has been compelled to administer his office with no adequate method for assembling operative administrative data. In any case the charter should be so amended that accounting control would be made consistent with efficient administration. 
CRITICISM AND COMMENT ON THE ACCOUNTS OF DEPARTMENTS EXAMINED

To restate the general situation in the departments visited: In each of them there was found a system of uncontrolled accounts kept by funds and appropriations, the only administrative purpose for which would seem to be to inform the department head with respect to the balance of funds and appropriations unexpended - information which by charter is required to be furnished

General criticism restated monthly to the heads of departments by the comptroller. The present accounting system presumes that the mayor and other administrative heads are not interested in economy and efficiency while the charter makes them responsible. The present system presumes that the only question in which executives are interested is whether departments are keeping within appropriations authorized - knowledge for which the comptroller and the city chamberlain are made responsible and which looks toward financial rather than executive control. If the head of the department or the mayor desires operative data these are to be collected spasmodically by the Commissioners of Accounts or are to be tabulated currently in the form of uncontrolled departmental statistics. In several of the departments, therefore, there are two distinct branches of the clerical service, one duplicated in the Finance Department keeping fund accounts, and the other one uncontrolled by accounts but keeping statistical records of its own making.

An example of the practice last above referred to as

Bellevue and allied hospitals well as of useless complexity of records is found in Bellevue and Allied Hospitals. By reference to the special report submitted to the committee on accounts and statistics, it will be seen I8 
(I) that the system of organization of Bellevue and Allied Hospitals is unnecessarily involved; (2) that there is a needless multiplication of work and of entries; and (3) that with all this expensive machinery there is no commensurate result which will give to those in discretionary position an intelligent basis for judgment with respect to problems of administration. The following list of books kept in the department shows multiplication of records:

I. Books and records kept by the purchasing agent - called in the department "the Bookkeeper":

I. "Contract Book."

2. Order press-copy book - called "Letter Book."

3. Order and Requisition Register - called "Requisition Book."

4. Invoice Register - called "Memo. Invoice Book."

5. Invoice Distribution Book - called "Appropriation Charge Book."

6. Invoice File - called "Invoices."

7. Invoice Register (2d) - called "Stock Ledgers."

8. Three Purchase Ledgers - called "Stock Ledgers."

9. "Journal."

Io. Purchasing Agent's General Ledger - called "General Ledger."

II. "Trial Balance."

II. Books and Records kept by the General Storekeeper:

I. "Order Register."

2. "Requisition Book."

3. Memoranda of Goods Forwarded - called "Memo. Book."

4. Combination Register of goods received at the branch stores direct and of goods delivered to the branch stores by the General Storekeeper - called "Invoice Book." 
5. Verified Record Invoices - called "Manifold Book."

6. A final manuscript record of distribution of goods to Hospitals - called "Distribution Book."

7. "Stock Ledger."

III. Books and records of general account kept by the Department Accountant - called "the Auditor":

I. "Bid Proposal Register."

2. "Requisition Book."

3. "Invoice File."

4. "Invoice Record."

5. "Voucher Book."

6. "Ledger."

7. "Recapitulation File."

The needless multiplication of work and entries is best seen in a restatement of the facts: Orders are copied three times, invoices are copied in toto twice; they are initialed fifteen times - five times on each of three copies; they are stamped six times - twice on each of three copies; they are numbered six times - twice on each of three copies; the name of the contractors in each invoice is written in the books ten times; the date on each invoice appears in the books sixteen times; the amount of each invoice is written ten times; the quantity of goods on each invoice is written seven times; the invoices are distributed to the same appropriation five times; and the requisitions are recorded six times.

While the controlling accounts of the Street Cleaning Department are practically the same as those kept by the Finance Department, the distribution for statistical purposes is highly classified and better adapted to obtainThe street ing administrative results than that of any cleaning de- other operative department visited. The partment inability to obtain accounting results which will give to the head of the department, and to the mayor 
as chief executive, an adequate basis for intelligent direction and control is due to lack of general accounts which will make this information currently available as a matter of acquiring control.

The docks and the municipal ferries of the city are in the nature of municipal industries, being operated on the basis of commercial remuneration received from those who avail themselves of this branch of the municipal service. The accounts should therefore show relations of operating expenses to income in order that those in Docks and ferries administrative position may know whether fees and charges are adequate to protect the city from loss, whether the properties are being properly maintained out of current incomein fact should answer every operative question which would be necessary to intelligent and effective control in case the department was operated as a private corporation. Aside from operative control there should be accounts which would protect the fidelity of employees, and to this end there should be a strict accounting for stock, materials, and supplies as well as of cash.

Operative accounts are lacking and the system of stockkeeping and stock-accounting is lax. The mayor wishing a statement as to the cost of operating a municipal ferry, it is necessary for the clerical staff of the department to make a special investigation and report. The cash accounting on the other hand is well adapted to the exercise of financial control.

Soon after the organization of the advisory Commission in Finance and Taxation, the chairman of the sub-com-

The Board of Education by him on the system employed in this department of mittee on accounting and statistics was requested by the president of the Board of Education to report to a committee appointed 
municipal activity. This was undertaken with the understanding that such part of the report as might be deemed of interest to the advisory commission might also be submitted for their consideration. In the course of the examination every branch of the department was visited and every important record kept in these branches was examined; forms and statements were obtained from heads of bureaus and employees were interviewed; conferences were had with members of the board and of important committees as well as with superintendents of instruction. The report as rendered to the committee of the board was based on the signed statements of members of the board and heads of bureaus.

Later, as a means of verifying, from independent sources, the methods of the department, Dr. W. R. Patterson, and Mr. H. H. Rathyen of the Comptroller's Department, were asked to prepare a statement of method; but on calling at the office of auditor of the department they were refused access to the books. An amended statement of the report made to the committee appointed by the president of the board is herewith submitted (Chapter XVII), and made a part of this report. In general it may be said that the accounts of the board are accounts designed for financial control, but have little regard for questions of administrative efficiency, economy of operation, or other matters of executive concern. Since the report was made to the committee of the Board of Education, the auditor has proposed a revision of the accounts to accord with some of the suggestions made, but in these he seems not to have grasped the administrative aim and purpose of executive and operative accounts. Efforts have also been made by the board through the supply department to get at relations of economy in matters of fuel, etc., as a result of which it is reported that large reduc- 
tions have been made in the cost of physical operations.

While efforts to solve administrative questions by independent statistical methods may prove of eminent service to an institution, the only safe, accurate, and economical way of obtaining current information necessary to intelligent executive control is to make this a matter of current and controlled accounting - to have the data obtained in such way that the whole system will at once feel the shock of any inaccuracy in statement and to make this data availDepartment able soon after each monthly closing. Much statistics

time is now spent in the departments in keeping unnecessary multiple accounts looking toward financial control; much time is lost in statistical investigation and special reports as a means of obtaining information which may serve the executives in giving direction to the city's affairs. This may be done away with by the installation of administrative accounts in the departments which will regularly and currently place the data desired before department and executive heads. Besides the government of the city may be much more effectively managed and controlled by having accurate and well-classified reports of operative results constantly before those in position of official responsibility.

Not the least among the benefits to be derived from a system of accounts designed to give executive control is Need for better that reports may be regularly and promptly Need for better rendered to the public by means of which
reports intelligent judgment may be exercised in the choice of officers - in other words such a system of reports is necessary not only for administrative control but also as a means of obtaining operative control over the officers and agents of the city entrusted with the management of its affairs. 


\section{CHAPTER XVII}

Principles Governing the Making of a School REPORT ${ }^{1}$

BEFORE subjecting the reports to a critical analysis submitted, it is to be noted that no access has been had to the books and records of the Board of Education from which these reports were drawn, nor to the books and records of the comptroller of the city of New York, where the treasury accounts and central records of school funds are kept. The opinion applies only to the reports themselves. The bases for the criticisms herein offered are found (I) in the Law (i.e., the constitution and statutes of the State of New York, and the charter of the city of New York, which provides for the organization of schools, the care and distribution of funds, the preparation of budgetary estimates for apportionment and appropriations, for the levying and collection of revenues, etc.), (2) in the evident purpose of making such reports, and (3) in certain assumptions made as to what the content of a report should be as determined by legal requirements and the evident purpose of the exhibit.

\section{THE PURPOSE OF MAKING REPORTS}

The evident administrative purpose of making and publishing a report of any department of municipal ser-

${ }^{1}$ Opinion rendered to Dr. William H. Allen, General Agent of the New York Association for Improving the Condition of the Poor relative to the administrative and instructional value of the Fifth Annual Report of the Department of Education (for 1902) and of the Fifth Annual Report of the City Superintendent of Schools (for 1903). 
vice is twofold: (I) To lay before officers and administrative agents such well-digested information as Departmental reports will give to them the data for the exercise of sound discretion in the performance of their duties and for the protection of public welfare; (2) to bring before the public such records of service rendered by public officials and such summaries of administrative results as will inform them of the doings of the agents into whose hands the affairs of the city have been placed. Both of these purposes are within the duties of office, to the discharge of which an adequate report is essential.

While the report of a subordinate officer within a department (one having direction and control over a certain division of departmental work and whose duties are special within the administrative group of which the department is composed) is governed by the same general purposes, it is limited by the narrower scope of official duties. Such an officer cannot intelligently represent the

Reports of subordinates work of the department. His report is not to the general government of the city, and should form no part of a report of the general government to the citizens. His return is to the head of the department to which he belongs and within which his special duties lie.

The purpose of a special report, as distinct from that of the report of a department, is to convey to those in charge of the department, and to whom the one making it is officially responsible, such detailed information and summaries of transactions as may serve as a guide Special reports for administrative judgment within the department. It should also be the means of supplying the data from which certain portions of the report of the head of the department to the chief executive officer of the city may be drawn. From the many special 
reports a general report of the work of a department may be compiled; but the first may also have a significance in themselves that will warrant individual publication. Whatever may be the reasons for its separate circulation, however, when so published it must be regarded as a document supplementary to the general report of the department containing details in which the officers of administration and the public may be separately interested, but which could not be conveniently handled in the general publication.

\section{WHAT A PUBLISHED REPORT SHOULD CONTAIN}

The second criterion for judgment of the reports of the Board of Education and its superintendent has reference to content, or the character and completeness of the data exhibited. A general guide to content is found in the purpose of the report, and in the Law, in so far as this contains a prescription. Generally speaking, however, legal prescriptions proceed from a failure on the part of officials to properly perform their duties with respect to the demands of government for information and the claims of the public on their agents for a proper report of their doings. A report should exhibit in a welldigested form all the data pertaining to the branch of service represented which will be of interest to the officers in control, or to the public. To apply this to the two reports in hand: The duties and responsibilities of the city What a super- superintendent of schools pertain to serintendent's re- vices rendered or to be rendered by the port should educational staff. $\mathrm{He}$ is the administracontain tive head of public instruction in the city of New York. He is not the head of the Department of Education - this position is occupied by the Board of Education. He does not direct the administration of the 
Department of Supplies, nor is he responsible for Buildings and Grounds; he has no control over the financial administration or financial records. Any data that he may obtain which relates to these several subjects must come as a matter of voluntary inquiry and response; as to subjects outside of his province his report could not be official. As the head of public instruction, what should an officer report to the Board of Education, and through the board to the public? Evidently the content of the report should be confined to the content of his powers and duties - a report of purely educational services rendered.

The same standard as to content would require that the report made by the Department of Education to the chief executive officer of the city (the mayor) be an entirely different one, both for the information of officers of administration and for the enlightenment of citizens and taxpayers. A published report from the board, as the What a report official head of the department, should set of a board forth in clear light and in readily intelligible should contain form all the data of interest pertaining to work of this entire branch or department of municipal activity. The following relations and conditions are fundamental: The Department of Education has been organized and officered to render a special class of service; to accomplish the ends of its creation the department must be suitably equipped; as a means of employing officers and providing equipment, funds are necessary. These fundamental facts lend public as well as administrative interest to three principal inquiries, answer to which should be contained in a published report, viz.: (I) What is the service rendered by the department and by what agents? (2) What is the equipment provided and in hand for rendering service? (3) What are the financial provisions made and the financial results of administration? 
An adequate report on the first subject suggested (service rendered) would require at least two distinct exhibits, viz.: (I) A statement pertaining to the purely educational service rendered, the data for which should be made available to the board through the report of the city

Report as to service rendered superintendent of schools, and (2) a statement of administrative service, or that which is incidental to providing the agencies and equipment necessary to the rendering of the purely educational service. The former would include the services of supervising and teaching staff; the second would include the services of the Board of Education and of the several administrative bureaus or divisions organized under it the Department of Supplies, the Division of Buildings and Grounds, etc.

Data pertaining to the second subject of inquiry (equipment) are of interest only in so far as they may be correlated with the purposes to which equipment is applied. These purposes are: (I) Superintendence and instruction, and (2) general administration. In each of these relations three distinct classes of properties are in Report as to
equipment used equipment, and $(c)$ furniture, apparatus, etc. Again, the city has two distinct relations to real estate and buildings and equipment - i.e., as owner and as lessee. These various related conditions give to the board a basis for the classification of data, which may be amplified by subclassification and comparison in such manner as to answer specific questions of public and administrative inquiry.

Report as to financial relations and results

As a means of properly understanding financial operations and their results, both the public and those in administrative control would have a final statement and report showing (I) relations of economy, drawn from a compari- 
son of income and expenses with service rendered, (2) relations of proprietorship, or the finances pertaining to property and equipment acquired and liabilities incurred, and (3) relations of fidelity of subordinate officers or agents as trustees or custodians.

If the report of the city superintendent of schools contains all of the information that the public or officers of administration may demand pertaining to Premises sum- instruction rendered, and if the report of
marized the Department of Education conveys the information desired on the main subjects of interest above set forth, then there can be no room for criticism as to content; in such case the only criticism that might be offered would go to the form or method of exposition; the inquiry to be raised would be as to whether or not the data might not have been set forth in such a way as to make the conclusions more clear and more readily intelligible to the reader. If, on the other hand, information as to any of these leading points is lacking, then assuming that the standard for judgment is accepted, criticism must be directed to the content of the reports as well as to the form and style.

THE CONTENT OF THE "FIFTH ANNUAL REPORT OF THE CITY SUPERINTENDENT OF SCHOOLS"

The "Fifth Annual Report of the City Superintendent of Schools" is contained in the first one hundred and twenty-nine pages of the volume bearing that title. This report is supplemented and supported by exhibits containing reports of subordinates, which, together with a small amount of general information, make up the remaining portion of a book of three hundred and fifty pages. This general arrangement of report and subsidiary exhibits conforms to the usual method of presentation. As 
to content, also, in so far as the attempt is to set out the data pertaining to the duties and activities of the Principal sub- office of the city superintendent and of his jects reported subordinates, there is little else to suggest. on

There are three general subjects reported on, and these coincide with the three subjects concerning which information is desired, viz.: (I) The adequacy of schools and departments of instruction to render service; (2) the organization of the supervising and teaching staff; (3) the educational service rendered. Further data might have been introduced to give completeness to summaries showing organization of supervising and teaching staff, as well as summaries pertaining to service rendered. This criticism refers especially to the lack of data pertaining to evening schools, vacation schools, recreation centres, playgrounds, special classes, etc.

As to content, the chief criticism would be that the superintendent has attempted to report conclusions, and to exhibit data pertaining to subjects entirely outside of the scope of his official duties and responsibilities. Reference is here made to such exhibits as the following: " $\mathrm{Ex}$ penditures for school purposes," pp. I20-3; "per capita cost of instruction," pp. I 24-7; "litigation and diminished appropriations," pp. I $2 \tau_{-1}^{-8}$; "new buildings and equipment," pp. 23-3I ; etc. It is to be remembered that the Chief criticism superintendent's report is to the Board of as to content Education as the head of the department in which he is an officer, and that the board has better facilities for obtaining information pertaining to the financial administration of schools than has the superintendent - in fact, the information exhibited to the board by the superintendent must first be obtained by him from the board. The same criticism holds true with reference to exhibits of buildings and equipment; 
the information given comes second-hand. The superintendent of buildings, and other officers entirely outside of the authority of the superintendent - those responsible and directly subordinate to the Board of Education are the ones from whom this information is to be obtained. There is no reason why the superintendent may not make use of any data obtainable from reliable sources for the purpose of presenting the needs and activities of his own department, but the exhibits here referred to are not of this kind. They are in the nature of a presentation of facts as information to the board and through the board to the public. Even though the Board of Education might fail in its duty (to the general government and to the public) to make a proper exhibit of certain branches of its own work, there is no reason why the superintendent should assume responsibilities which he cannot meet. Such unofficial information weakens his own report and at the same time tends to shift attention from the weakness of the report of the board.

THE REPORT OF THE CITY SUPERINTFNDENT CONSIDERED FROM THE STANDPOINT OF FORM

Admitting excellence as to content in so far as the report deals with the functions and duties of the purely educational branch of the service, any attempt to review the form and method of exposition must be undertaken with considerable hesitation. In representing a view, therefore, reasons are given, and these reasons are offered as subjects for consideration.

While the literary style of the report is such as to carry the attention of the reader, an attempt to analyze the context and to fix the data in the memory discovers the fact that its plan is not easy to trace. Applying principles of exposition, it may be said that the form does not 
give emphasis to conclusions. Again, the use made of outline report tables and statistical statements of general subjects of conclusions reached has not been such as principal in- to strike the eye; these oftener follow rather terest

than precede the textual treatment. Any attempt made to suggest an outline or to restate the report might be open to as serious objection. But assuming for the sake of illustration that the three main subjects of administrative and popular interest are as above indicated; viz.: (I) the adequacy of schools and departments of instruction to render service, (2) the organization of the supervising and teaching staff, and (3) the educational service rendered - then these might be made the three main divisions of the report and all of the data might be organized accordingly. Attempting to reorganize the report along these lines, the following outline is submitted:

I. ADEQUACY OF SCHOOLS AND DEPARTMENTS OF INSTRUCTION TO RENDER SERVICE

I. Number and location of schools and departments of instruction organized.

(I) Number and classification, I9-22.

(2) Consolidation of schools, I07-8.

2. Prospective schools and departments of instruction.

(I) New buildings, 23-3 I.

(2) Brooklyn training school, 48.

3. Instruction needs not adequately provided for.

(I) Sittings and register, 35 .

(2) Increasing demands compared with new schools.

(a) Increase in average attendance, 35 .

(b) Growth in kindergartens, 40-4I.

(3) Need for special schools. 
(I) Training schools.

(a) Brooklyn, 48.

(b) Kindergarten training school, 49-50.

(2) High schools.

(a) Manual Training High School, 55.

(3) Schools for defective children, I IO-I 7 .

4. Vacation schools, playgrounds, and recreation centres, I I 7-I 8 .

5. School libraries, I I8-I9.

II. ORGANIZATION OF THE SUPERVISING AND TEACHING STAFF

I. General exhibit, 38 .

2. Supervising staff.

(I) Organization.

(a) Board of Superintendents, I6-I8.

(b) District superintendents, I8-I9.

(2) Methods for increasing efficiency of staff.

(a) Superintendents' conferences, I I9-I 20.

(b) Syllabus Committee, 70-72.

(c) 'Teachers' Plan Books, ıo8-ı ıо.

3. Principals and teachers.

(I) In elementary schools, 37-38.

(2) Educational and service requirements.

(I) Licensing, 42-49.

(a) Training school teachers, 42.

(b) High school teachers, 43.

(c) Elementary schools.

(I) Heads of departments, 43.

(2) Teachers of graduating classes, 43.

(3) Evening schools, 45 .

(d) Kindergartens, 44 .

(e) Special branches, 45 . 
(f) Substitutes, 45 .

(g) Vacation schools and playgrounds,

45 .

(2) Service recognition.

(a) License for promotion, 43 .

(b) Permanent licenses, 46-47.

(3) Teaching methods.

(a) Departmental system, 72-106.

(I) Schools employing plan, 75-6.

(2) Departmental work and teachers' interest, 76-9.

(3) Effect of departmental work on methods, 79-82.

(4) Effect of departmental work on students' interest, 82-89.

(5) Effect of departmental teaching on students' work, 89-92.

(6) Departmental plan and discipline, 92-98.

(7) Effect of departmental instruction on penmanship, 99-102.

(8) Summary, I03-106.

III. EDUCATIONAL SERVICE RENDERED

I. Courses of instruction offered.

(I) High schools, 54-55.

(2) Elementary schools, 62-72.

(3) Manual branches, 64-65.

(4) Electives, 65-66.

(5) Special branches, ro6.

2. School attendance,

(I) Enrolment.

(a) Net enrolment, 33 .

(b) Net enrolment and population, 33-34. 
(2) Average attendance, 52-53.

(a) Increase, 52-53.

(b) Increase in kindergartens, 40-4I.

(c) Distribution of pupils, 38-39.

(I) Distribution by sexes, 39 .

(3) Part time pupils, 36-37.

3. Graduates.
(I) Training schools, 48.
(2) High schools, $5^{-}-52$.
(3) Elementary schools.

(a) Average age of graduation, 4I.

Without offering the above as an outline for use, but simply for the purpose of discussion, it is urged that a plan which has in mind a definite answer to questions of prime administrative and popular interest should be adopted; that in developing this plan the general statistical tables and conclusions should first be presented; and that in the textual treatment and detailed statements

Principles of exposition these should be governed by questions of immediate interest at the time of making the report. In opposition, it may be argued that a subject may be best presented by putting the concrete first. This might be true if the primary purpose were to convince the reader as to the accuracy of the conclusions; it might also be accepted as a principle of research. The purpose of a report, however, is to present conclusions and not to argue them; to give confidence these may be supported by such details as may serve to illuminate the result. But aside from the academic reasons there are several practical ones. A very small portion of those interested in the report care to master the details; accepting the accuracy of statements, a general knowledge of results only is desired. This should be 
made the most accessible - if possible, capable of being taken in at a glance. A second practical reason is found in the fact that even a special feature may be better understood if looked at from the viewpoint of the relation of the special feature to the whole. A third reason is urged - that a statement of summaries and results not only gives to the reader a working hypothesis
general results as a basis for the investigation of details reported, but also forces a classification which will give greater clearness and consistence and better coördination to the textual and detailed discussion of the report itself. The same reasoning has led to the introduction of general tables and schedules at the beginning of a subject treated, when such devices may convey the general conclusion with greatest facility.

The following exhibits are given not as substitutes for any that may already have been made, nor for use in making a report, but simply for illustration of the principles of exposition above outlined. The first two schedules relate to $(A)$ Adequacy of Facilities for Rendering Service, and to the $(B)$ Organization of Supervising and Teaching Staff.

In the textual treatment given to these divisions of the report, following the tables, the several classes of schools and departments may be discussed and illuminated in the order adopted by the authorities as the basis for classification and tabular statement. Within each of the minor subjects so discussed may be inserted any specific tables or data that may contribute to the presentation. 


\section{ExHIBIT A}

General Exhibit of Number and Location of Schools and DEPARTMENTS OF INSTRUCTION

Higher Instruction.

Day Schools:

Training Schools.......

High Schools..........

High School Departments Evening Schoolş:

High Schools

High School Departments Elementary SCHOOLS AND BRANCHES:

Grammar Schools:

Day........................

Evening ............ 33

Kindergarten Classes ...... ${ }_{15}$

Vacation Schools ......... *

Recreation Centres........

Play Grounds.............

Work Shops ............

Training Schoo's........

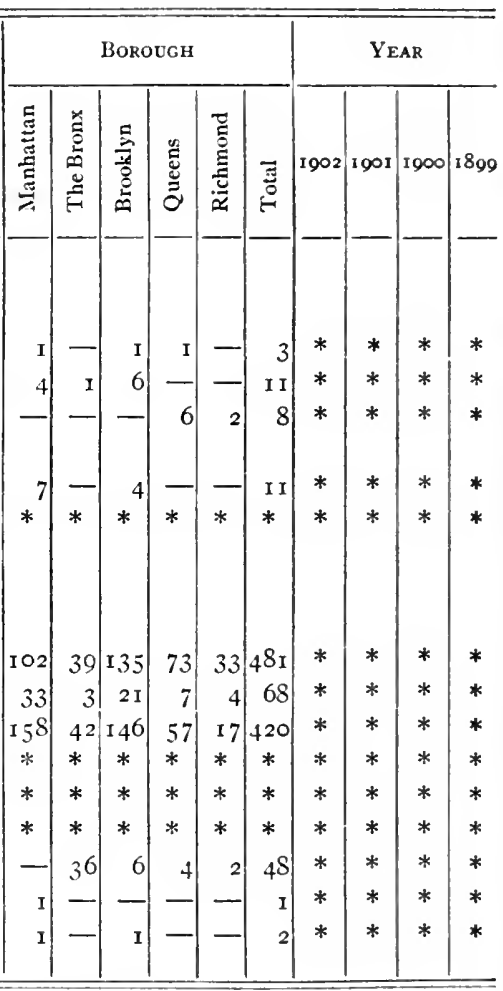

* Information lacking. 
Exнівіт B

ORganization FOR SUPERVISION OF INSTRUCTION

General Supervision:

Head City Superintendent

Associate Superintendents

Division Superintendents

Office Assistants.

Special Supervision:

Superintendent Vacation Schools, etc. ..

Superintendent Evening Schools........

Superintendent Training Schools ......

Office Assistants.................

PRINCIPALS:

Training and High Schools:

Manhattan

The Bronx

Brooklyn

Queens..

Richmond.

Elementary Schools:

Manhattan

The Bronx

Brooklyn

Queens

Richmond . .

Office Assistants

Other Supervising Officers:

Number.

Office Assistants

Total Officers.

Total Office Assistants

Grand Total

YEAR

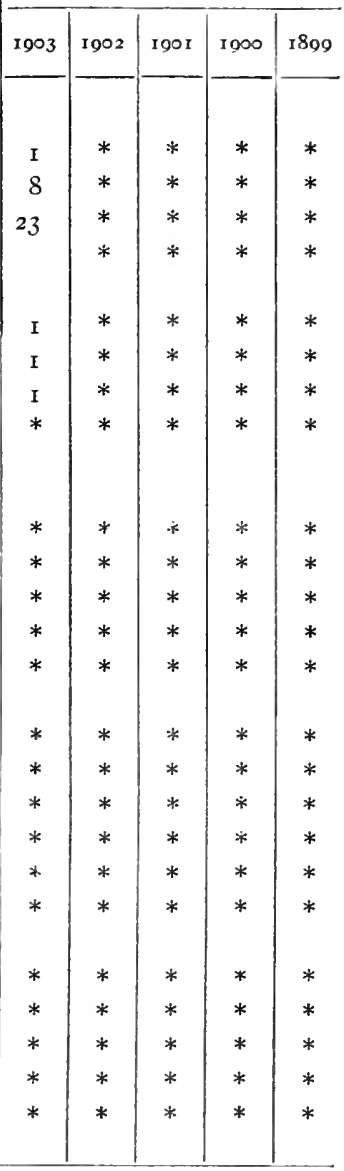

* Information lacking. 


\section{ExhiBIT B}

Teaching Staff by Boroughs

\begin{tabular}{|c|c|c|c|c|c|}
\hline & \multicolumn{5}{|c|}{ YEAR } \\
\hline & 1003 & 1902 & 1901 & 1900 & 1890 \\
\hline \multirow{2}{*}{\multicolumn{6}{|c|}{$\begin{array}{l}\text { ScHOOLS OF Higher Instruction: } \\
\text { Training Schools: }\end{array}$}} \\
\hline & & & & & \\
\hline 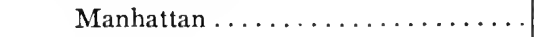 & $*$ & $*$ & $*$ & * & * \\
\hline Brooklyn................. & $*$ & * & $*$ & * & * \\
\hline 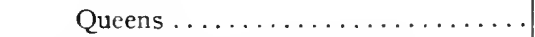 & $*$ & $*$ & $*$ & $*$ & * \\
\hline High Schools and Departments: & & & & & \\
\hline 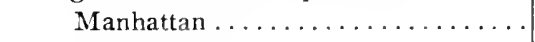 & $*$ & * & * & $*$ & $*$ \\
\hline 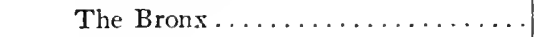 & * & * & * & $*$ & $*$ \\
\hline Brooklyn . . . . . . . . . . . . & $*$ & * & * & $*$ & * \\
\hline 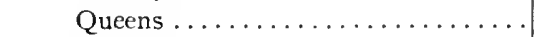 & $*$ & $*$ & * & * & * \\
\hline Richmond.$\ldots \ldots \ldots \ldots \ldots$ & $*$ & $*$ & $*$ & * & $*$ \\
\hline \multicolumn{6}{|l|}{$\begin{array}{l}\text { ELEMENTARY ScHools AND BRANCHES: } \\
\text { Grammar Schools: }\end{array}$} \\
\hline 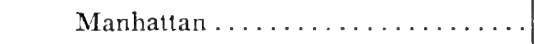 & $*$ & * & $*$ & * & $*$ \\
\hline The Bronx................. & * & $*$ & * & $*$ & * \\
\hline Brooklyn................... & * & $*$ & * & $*$ & * \\
\hline 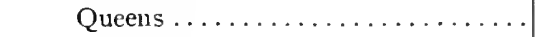 & $*$ & $*$ & $*$ & $*$ & $*$ \\
\hline Richmond . . . . . . . . . . . . & * & * & * & $*$ & $*$ \\
\hline \multicolumn{6}{|l|}{ Kindergarten Clas:cs: } \\
\hline 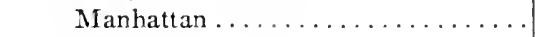 & * & $*$ & * & $*$ & * \\
\hline 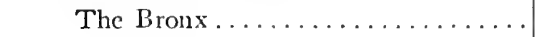 & $*$ & * & * & * & $*$ \\
\hline Brooklyn................... & $*$ & * & $*$ & $*$ & $*$ \\
\hline Queens ................. & $*$ & $*$ & $*$ & $*$ & * \\
\hline Richmond............... & $*$ & $*$ & * & $*$ & $*$ \\
\hline \multicolumn{6}{|l|}{ Special Branches: } \\
\hline Manhattan .............. & $*$ & $*$ & * & $*$ & * \\
\hline The Bronx ............ & * & * & * & $*$ & * \\
\hline Brooklyn.............. & $*$ & * & * & * & $*$ \\
\hline Queens ................... & * & * & * & * & * \\
\hline Richmond $\ldots \ldots \ldots \ldots \ldots \ldots \ldots$ & * & * & * & * & * \\
\hline Nautical School ............... & * & * & * & * & * \\
\hline Truant Schools.................. & * & * & * & $*$ & * \\
\hline Other Teaching Staff .............. & * & * & * & * & * \\
\hline Total $\ldots \ldots \ldots \ldots \ldots \ldots \ldots$ & * & $*$ & * & * & * \\
\hline
\end{tabular}

* Information lacking. 
ExнiвIт B

Teaching Staff by Classes and Sexes

\begin{tabular}{|c|c|c|c|c|c|}
\hline & \multicolumn{5}{|c|}{ YEAR } \\
\hline & 1903 & 1902 & 1901 & 1900 & I899 \\
\hline \multicolumn{6}{|l|}{ SCHOOLS OF Higher INSTRUCTION: } \\
\hline \multirow{2}{*}{ Training Schools, Male ........ } & $*$ & * & $*$ & $*$ & $*$ \\
\hline & * & * & * & $*$ & $*$ \\
\hline \multirow{2}{*}{$\begin{array}{r}\text { High Schools, Male ...... } \\
\text { Female.... }\end{array}$} & * & $*$ & $*$ & $*$ & $*$ \\
\hline & $*$ & $*$ & * & $*$ & $*$ \\
\hline \multirow{2}{*}{$\begin{array}{r}\text { Total, Male } \ldots \ldots \\
\text { Female........ }\end{array}$} & * & * & * & $*$ & $*$ \\
\hline & * & $*$ & $*$ & $*$ & $*$ \\
\hline \multicolumn{6}{|l|}{ ELEMENTARY ScHOOLS: } \\
\hline \multirow{2}{*}{$\begin{aligned} \text { Grammar, Male.... } \\
\text { Female. }\end{aligned}$} & $*$ & $*$ & $*$ & $*$ & $*$ \\
\hline & * & $*$ & $*$ & $*$ & $*$ \\
\hline Kindergarten, Male............ & $*$ & * & * & $*$ & $*$ \\
\hline Female........... & $*$ & $*$ & $*$ & $*$ & $*$ \\
\hline \multirow{2}{*}{$\begin{array}{r}\text { Special Branches, Male .... } \\
\text { Female .. }\end{array}$} & $\ddot{*}$ & $*$ & * & $*$ & $*$ \\
\hline & 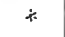 & $*$ & $*$ & $*$ & $*$ \\
\hline \multirow{2}{*}{$\begin{array}{r}\text { Truant, } \\
\text { Female } \ldots \ldots \ldots \ldots \ldots \ldots \ldots \ldots \ldots \ldots \ldots \ldots\end{array}$} & $*$ & $*$ & $*$ & $*$ & $*$ \\
\hline & * & $*$ & $*$ & $*$ & $*$ \\
\hline \multirow{2}{*}{$\begin{aligned} \text { Nautical, } & \text { Male..... } \\
& \text { Female... }\end{aligned}$} & $*$ & $*$ & $*$ & $*$ & $*$ \\
\hline & $*$ & $*$ & $*$ & $*$ & $*$ \\
\hline Other Teachers, Male .......... & $*$ & $*$ & $*$ & $*$ & $*$ \\
\hline Female $\ldots \ldots \ldots$ & $*$ & $*$ & $*$ & $*$ & $*$ \\
\hline \multirow{2}{*}{$\begin{aligned} \text { Total Elementary, Male.... } \\
\text { Female. }\end{aligned}$} & $*$ & $*$ & $*$ & $*$ & $*$ \\
\hline & $*$ & * & * & * & $*$ \\
\hline 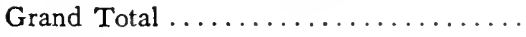 & $*$ & $*$ & $*$ & $*$ & $*$ \\
\hline
\end{tabular}

* Information lacking.

With regard to superintendence and instruction, facts Comment on special topics must now be sought in various widely separated parts of the superintendent's report, as follows: In statements pertaining to the organization of the Board of Superintendents (pp. r6-18); in the exhibit of organization of the district superintendents 
and a statement of their assignments and duties (pp. I8-I9); in the list of the Board of Special Examiners (p. Io); in the list of special assignments for evening schools, recreation centres, etc. (p. I 9); in the tabulated summaries and classified statements with reference to teachers (pp. $\left.3^{2}, 37,3^{8}\right)$; etc. Consolidation and correlation as suggested above would obviously facilitate a proper appreciation of any topic of special interest and eliminate whatever textual comment might be thought to be necessary to an understanding of those functions of the Department of Education that fall under the authority of the superintendent.

The third division, Educational Service Rendered, may also be introduced by a general tabular statement. Whatever the form of the table, it should give answer to the questions of administrative concern and popular inquiry. In answering these questions, the facts and conclusions should not only be set out in such a manner as to repreShould lay sent teaching service, but to lay the foundafoundation for tion for such portions of the general report board's report of the Board of Education as depend on the report of the superintendent. The same purpose and necessity would determine the arrangement and classification of textual treatment, of detailed exhibits and of special summaries.

Some of the subjects of administrative and popular interest at the present time pertain to evening schools, why complete special branches, vacation schools, and recshowing should reation centres. To specific inquiries on be made

points of current interest special textual treatment and detailed exhibits may be given. But information on topics of special interest is only incidental to the report; its primary purpose is to enlighten the administration in the performance of duty and to enlighten 
the public concerning the doings of their corporate servants. It is essential to both purposes that information be given on all branches of the service. Likewise it is to the advantage of the officer whose duty it is to make the report. For example: A subject that has not been made a matter of interest, but to which serious consideration may be given, is that of the private (so-called corporate) schools to which the city is giving large revenues each year. These contributions are supposed to rest on a pseudo-control. The administration and the public should have definite knowledge of the character of instruction given and the educational results accomplished by these legatees under the law as it at present stands. Should controversy arise at any time concerning these schools, the officer whose duty it is to report such information might be justly condemned for withholding it or failing to make it accessible.

THE "FIFTH ANNUAL REPORT OF THE DEPARTMENT OF EDUCATION" - ITS FORM AND METHOD OF PRESENTATION

The "Fifth Annual Report of the Department of Education" to the chief executive officer of the city would seem to possess few features measuring up to any accept-

Defective charable standard, either for the guidance of acter of report

officers or for the information of the public.

Nor can the general excellence of the exhibit made by the superintendent of schools be considered as an exonerating circumstance. It has already been suggested that the report of the superintendent of schools cannot be a substitute for a report from the board; that he does not report to the mayor; that he cannot officially report on any matter that does not come within the range of his duties and activities; that the purely educational 
activities of the department form only one part of one of the three general subjects of interest to be presented by the Board of Education to the mayor. True, the detailed information from which the report of the Board of Education is to be drawn must be derived in considerable measure from the several responsible officers within the department, and this information is obtained by the board in the form of documents submitted, which may be appended for further illumination. But admitting all this, the reproduction of these documents or subordinate reports cannot be considered as a proper method of reporting the activities of the department as a whole. Aside from commanding reports from subordinates the board has a duty to perform.

The "Fifth Annual Report of the Department of Education" contains four classes of material, viz.: (1) The signed report or letter of transmission; (2) a financial statement; (3) reports of subordinate officers, with property schedules; and (4) a directory of official members of the staff of superintendence and instruction. The signed report or letter of transmission occupies the first twenty-two pages. Of this all but one page is an excerpt from the report of the superintendent of schools, and this one page is made up of an excerpt from the law. The second section, or the "financial report," is presented in one hundred and fifty-four pages. Following this are the signed reports, in haec verba, made by the superintendent of school supplies (forty pages), the superintendent of lectures (fifty-four pages), the superintendAnalysis of published report ent of the Nautical School (ten pages); a statement of school sites (twenty pages); a list of officers and staff (twenty pages), and the school directory (thirty-six pages). In the whole volume, containing four hundred and twenty-one pages of printed 
matter, there does not seem to be any attempt to lay before the officers of the department itself, or before the general officers and administrative agents of the city, such a digest of information as will give to them the data necessary for the exercise of sound discretion in the performance of their duty and for the protection of the general welfare; nor does it bring to the public such record of service rendered by public officials and such summaries as will inform them of the doings of those agents into whose hands the educational affairs have been placed. The only part of the document which purports to come from the board is that contained in the financial exhibit. Whatever may be the content of the volume, so far as it pertains to the subjects of principal public interest or administrative inquiry, the information given must first be searched out by the reader from the mass of special and subordinate documents and detailed statements.

We turn to the content or substance obtainable after this heterogeneous array has been analyzed and digested. Invoking as a standard for judgment that the board in its official capacity, as head of the department, has a duty to perform, and that this duty is to report to the executive officers of the city as well as to the public all the data pertaining to the work of this branch of municipal activity which may be of interest to either, the analysis is proceeded with.

\section{CONTENT OF THE REPORT AS TO SERVICE RENDERED}

Pertaining to service rendered, such information as is contained in the report of the department is in the first section. From page 8 may be drawn the following summary: 
Number of schools under jurisdiction of Board............

Number of teachers (exclusive of teachers of special branches, directors, and superintendents) $\ldots \ldots \ldots \ldots \ldots \ldots \ldots$ II,74I

Total number of pupils on register in elementary schools ... 43r,49I

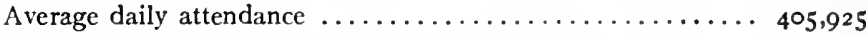

Number of high schools and training schools............ I

High school departments in the Borough of Queens......... 6

High school departments in the Borough of Richmond ...... 3

Total number of teachers (high school)............... 680

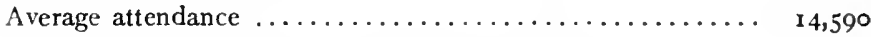

Number of corporate schools and societies (Manhattan) .... 17

Number of corporate schools and societies (Brooklyn)....... II

Total corporate schools and societies ............... $\quad 28$

Number of teachers in corporate schools.............. $\quad 560$

Number of pupils in corporate schools ............. 19,829

This summary is not presented (as is shown above) in tabular form, but the information is found in a running text; it is the only summary given of educational service rendered in high schools, training schools, elementary schools and other schools under the jurisdiction of the board. No separate summaries are given pertaining to the several classes of schools. The detailed exhibits which follow contain nothing but schedules of registration and average attendance, and in this the classification is by individual schools and boroughs. To show the character of the exhibit, the following excerpt is given:

\begin{tabular}{|c|c|c|c|c|c|}
\hline $\begin{array}{c}\text { Public School } \\
\text { Department }\end{array}$ & $\mid \begin{array}{c}\text { Register } \\
\text { July } 3 \mathrm{I}, \mathrm{I} 902\end{array}$ & $\begin{array}{c}\text { Average At- } \\
\text { tendance for } \\
\text { Year }\end{array}$ & $\begin{array}{l}\text { Public School } \\
\text { Department }\end{array}$ & $\begin{array}{c}\text { Register } \\
\text { July } 31,1902\end{array}$ & $\begin{array}{c}\text { Average At- } \\
\text { tendance for } \\
\text { Year }\end{array}$ \\
\hline 56 P. D. & 586 & 626 & 77 B. D. & I , 4 I 5 & $I, 462$ \\
\hline 57 G.D. & $85^{6}$ & 743 & 77 G. D. & 1,371 & 1,347 \\
\hline 57 P. D. & $\mathbf{I}, 560$ & 1,577 & 78 G. D. & 959 & $\delta_{10}$ \\
\hline $5^{8}$ B. D. & 868 & $75^{8}$ & 78 P. D. & 672 & 735 \\
\hline 58 P. D. & 740 & $7+9$ & 79 B. D. & I, 041 & 903 \\
\hline
\end{tabular}

Whatever may be said of a showing of this kind in the 
report of the superintendent of schools to the board it is submitted that the general summary exhibited and the Defects in nineteen solid pages of detailed statistics report of such as above referred to are not sufficient educational ser- information to enlighten the officer or to vice rendered satisfy the inquiry of a taxpayer as to the educational and administrative public service rendered by the Department of Education of the city of New York. It is submitted that in the detailed statistical subjects treated, the content is not sufficient, and further, that the form of presenting these statistics is not such as to be readily understood and grasped. In other words, that the report in so far as it attempts to represent service rendered is deficient in content as well as to form of presentation.

The objection is often urged that the benefits of destructive criticism are lost because no accompanying suggestion is made for improvement. In this relation, it is to be remembered that constructive criticism and suggestion should flow from a more exact knowledge of records and of conditions present than may be had from the report itself, which is made the subject of the foreSubjects for going strictures. But certain general topics report on of interest may be pointed out from a "Educational" knowledge of the law governing the organservice found ization of schools and from a general
in the law understanding of the nature of the service rendered. By provision of charter (Sec. I069), power is expressly conferred on the Board of Education to establish and conduct the following classes of instruction:

(I) High Schools and Training Schools for teachers.

(2) Elementary Schools (in addition to regular grade schools). 
(r) Kindergartens.

(2) Manual Training Schools.

(3) Trade Schools.

(4) Truant Schools.

(5) Vacation Schools.

(6) Evening Schools.

(7) Special Classes.

(8) Free Lectures.

It appears from the financial and other sections of the report of the board, and from the report of the superintendent of schools, that these several classes have been established and are being conducted. In addition to the above enumerated classes of instruction, the law (charter, Sec. II $5^{2}$ ) has also recognized certain private schools as a part of the educational system of New York. It is further to be noted that still another class, viz., instruction conducted in what are known as recreation centres, is being given. Without attempting to prescribe forms or schedules, it may be consistently urged that the public, as well as responsible officers and agents, would be interested in having well-digested information presented (in statistical summary and in subsidiary schedules and exhibits) showing the service which is being performed in the several classes and departments of instruction, and that this information be reduced to such a basis that comparison may be instituted for the purpose of determining the relative educational efficiency of each.

Still another branch of inquiry as to service rendered

Subjects for report on administrative service is found in the general administration of the department, at the head of which is the Board of Education itself. To give conciseness to the suggestion, the textual treatment of this branch of departmental activity might be 
preceded by a tabular statistical summary of the main facts and conclusions reached. Without claiming for the form conformity to the exact need, the table below is suggested for the purpose of illustrating the character of exhibit referred to.

Statistics of School Operation - General Aduinistration

\section{BOARD OF EDUCATION:}

Members of the Board

Subordinate Officers of the Board, Male

\section{Female.}

Clerks and Stenographers, Male.....

$\mathrm{Y}_{\mathrm{EAR}}$

Female ...

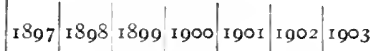

Janitors and Caretakers, Male ......

Female .........
Female.....

Total Num. Empl. in the Gen. Offices, Male

Female.

Total.

Department of Supplifs:

Officers and Assistants, Male.

Stock Clerks, etc., Male

Female.

Female

Caretakers, Male

Female

Total in Dept. of Supplies, Male....

Female...

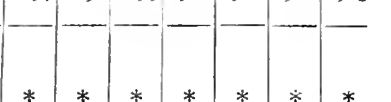

Total.

\begin{tabular}{|c|c|c|c|c|c|c|}
\hline * & $*$ & $*$ & * & $*$ & $*$ & * \\
\hline * & * & * & $*$ & * & * & $*$ \\
\hline$*$ & * & $*$ & * & * & $*$ & $*$ \\
\hline * & * & * & * & * & * & $*$ \\
\hline * & * & $*$ & $*$ & $*$ & $*$ & $*$ \\
\hline$*$ & $*$ & $*$ & $*$ & $*$ & $*$ & $*$ \\
\hline * & * & * & $*$ & $*$ & $*$ & $*$ \\
\hline * & * & $*$ & * & * & * & $*$ \\
\hline$*$ & * & $*$ & $*$ & * & $*$ & $*$ \\
\hline$*$ & $*$ & $*$ & * & * & $*$ & $*$ \\
\hline$*$ & $*$ & $*$ & * & $*$ & * & $*$ \\
\hline * & $*$ & * & $*$ & $*$ & * & $*$ \\
\hline$*$ & * & $*$ & $*$ & $\neq$ & * & $*$ \\
\hline$*$ & $*$ & $*$ & $*$ & $*$ & $*$ & * \\
\hline * & $*$ & $*$ & $*$ & $*$ & * & * \\
\hline$*$ & $*$ & * & * & * & * & $*$ \\
\hline$*$ & $*$ & $*$ & $*$ & $*$ & * & * \\
\hline$*$ & $*$ & $*$ & * & $*$ & $*$ & $*$ \\
\hline * & $*$ & $*$ & * & $*$ & * & $*$ \\
\hline$*$ & $*$ & $*$ & $*$ & * & * & * \\
\hline
\end{tabular}

* Information lacking. 
Statistics of School Operation - General admintstraTION - Continued

SUPERINTENDENCE OF BUiLdings:

Superintendent and Assistants, Male. . Female

Clerks and Stenographers, Male..... Janitors, Male.

Female...

Female

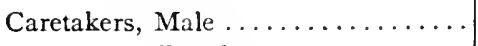

Female ..............

Carpenters, Electricians and Skilled Men

Other Laborers

Total under Super. of Buildings,

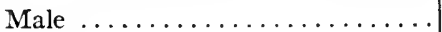

Female ....................

\begin{tabular}{r|c|c|c|c|c|c|c} 
Total............................. & $*$ & $*$ & $*$ & $*$ & $*$ & $*$ & $*$ \\
Total Employed in Gen. Admin., Male.. & $*$ & $*$ & $*$ & $*$ & $*$ & $*$ & $*$
\end{tabular} Total

\section{* Information lacking.}

In the literary presentation of subjects of "service," all of these several relations indicated might be illuminated and enlarged upon by subsidiary schedules and such exhibits as might be necessary to give public confidence in the result obtained or to furnish the detailed information required as a basis for administrative discretion and critical judgment. 
CONTENT OF THE REPORT OF THE BOARD OF EDUCATION PERTAINING TO PHYSICAL EQUIPMENT PROVIDED FOR SCHOOL PURPOSES

The only part of the report of the Board of Education which deals with school equipment is found in the reports of subordinate officers and in the schedules of sites and buildings. Of these no digest is made and no coördination is attempted by the board. In the report Defects in re- of the superintendent of school buildings port as to is found much of interesting data; this, equipment however, is ill-digested and has no summary which will catch the eye and quickly convey intelligence as to the physical aspects of the educational plant. In another section a report is found giving a list of school sites which have not been improved. But the best digest that can be made from the data here given leaves much lacking that is necessary to a proper understanding of equipment and leaves the reader without any information from which judgment may be made as to the fidelity of official custodians of property intended for public use. Neither is there any information which will admit of a conclusion with reference to adequacy of equipment and comparison with equipment needs.

As before suggested, there are two distinct purposes pertaining to education for which the property of the city under control of the board is used. These purposes may be described as : (I) General Administration; (2) Superintendence and Instruction. There are, moreover, at least three distinct classes of physical property to be accounted for, viz.: (I) Land for sites and playgrounds; (2) buildings and permanent improvements; and (3) furniture, apparatus, etc. If, therefore, an attempt is made to represent the several classes of property used for the 
several purposes suggested, it would be necessary to make

General subjects of interest with reference to equipment

a showing, statistically or otherwise, of the lands, buildings, and properties employed for administration purposes; and of the lands, buildings, and properties employed for superintendence and instruction. In representing further the properties employed for superintendence and instruction still other sub-classifications might be made which would show the properties and equipment used by the supervising staff and those in use by teachers and pupils. Some such representation might also be made with respect to prospective buildings, or those in the process of erection or for the erection of which some definite provision has been made (as that contained in the published report). By way of still further illuminating the textual discussion, the properties and equipment used for purposes of instruction might be classified according to the character of the several kinds of schools using them.

A classified statement of equipment such as that indicated, however, cannot be made of highest administrative use, and will not give to the public the best information, unless the general statistics are reduced to units of comparison. Among numerous units of comparison might be mentioned floor space occupied per student; cubic yards of air space of rooms occupied per student; text-books and supplies furnished per student, etc., arranged according to schools and classes of schools. Would not such facts be of distinct administrative advantage in judging physical conditions pertaining to health, comparative cost of heating, lighting, caretaking, repairs and replacements, etc.? The establishment of units of comparison would also be necessary to a popular estimate of official ability in administrative and official custodianship and fidelity with reference to text-books, supplies, etc. 
To illuminate a discussion of properties and equipment an exhibit might be made of sites owned and sites leased, Should estab- building sites improved and unimproved, of lish units of temporary buildings compared with percomparison manent buildings, air space contained in each class per student, etc., etc. The floor and air space occupied for administrative and supervising purposes as compared with the space occupied for teaching purposes might also be brought into comparison. Various summaries and exhibits might be suggested to throw light on the problem of relation of physical equipment to service rendered, and also to furnish a basis for judgment with respect to administrative economy and use of property. The suggestion here as before is, not that the particular subjects above mentioned should be taken for illumination in reports, but, first, that whatever data might be considered of importance, the board is in a position to obtain the same at small expense, and, secondly, that it has a duty to report them to the chief executive officer of the city and through him to the public.

CONTENT OF THE REPORT AS TO FINANCIAL OPERATION AND FINANCIAL RESULTS

Among the most important divisions in a report of any department of municipal government is that which reflects financial relations and results. It is these relations that are first brought home to the taxpayer and to the municipal corporation at large. It is the financial side of operation which causes the citizen to ask concerning relations of cost to service rendered and economy of ad-

Defects in

financial report port ship and as to the fidelity of officers and
agents in the administration of public properties and ministration. It is financial interest, also, which institutes inquiry as to proprietor- 
in the creation of corporate liabilities. A report which attempts to reflect these results, therefore, should collect the financial data of administration around three principal categories, viz.: (I) Categories of economy of administration; (2) categories of corporate proprietorship; and (3) categories of fidelity of officers and agents. Turning again to the report of the Department of Education for these results we find it deficient in content as well as difficult to understand. From the report under review, little or no information can be obtained as to relations of administrative economy. The report reflects no basis for comparison of administrative cost among the several departments or among the several classes of institutions and departments of instruction. As a matter of expense, it may be proper to ask, What are the expenses incurred for instruction? What are the expenses incurred for general administration? What are the miscellaneous general expenses? And in making a showing of the expenses incurred for instruction it would be proper to inquire, What are the expenses of instruction within the several classes of schools and departments?

Inquiries of this kind are necessary, not only for the purpose of instituting a comparison of expenses with revenue and appropriations, but also that the experience of one year may be aligned with the experience of another year. As a further test for administrative economy, a unit of cost per pupil may be established that the inquirer may get at the relative expense of instruction within the several groups or departments. In examAbsence of ining the expenses of general administracomparative tion, it is proper to know what is the relative tables of cost cost of maintaining the board itself, and of the general administration of the Departments of Supplies, of Building Superintendents, of janitor service, etc. So, 
too, in making inquiry as to miscellaneous or general expenses, it may be of advantage to know the cost of heating and lighting per cubic unit; of caretaking per square unit, etc. In the exhibit made of the amount of fuel used, while the number of tons and pounds used in each building and the total cost are reported, there is no statement showing the prices per ton - the only intelligible key to a financial statement of a fuel account. Furthermore, the statements made in the report of janitor service, while long and given in detail as to the amounts paid to each person, contain no showing as to whether this amount is for salary or for some other purpose. Judging from the amount paid to each, in some instances running as high as $\$ 2,000$ or $\$ 4,000$, it is to be assumed that these in part are statements of moneys distributed through the person named. Classification is desirable that will not only show the several important items of cost, absolute and comparative, in total and by unit, but will also exhibit such relations as sinking fund requirements, and other current charges for which revenue contribution should be made.

Another subject for inquiry that comes properly within the term "economy" is to be found in an account and final showing of revenues provided for the purpose of meeting costs of administration, etc. As to this, the report made is inadequate. Section 226 of the charter provides for departmental estimates for the ensuing year. It further provides (Sec. I064, subsequently amended) for a tax the minimum amount of which shall not be less than three mills. Another provision is that the departmental Statements of estimate shall go before the Board of Estirevenues defec- mate and Apportionment, where the final tive

budget shall be determined. None of these financial relations are shown in the published report. The 
constitution, the statutes of the State of New York, and the charter further provide for income to the schools of the city for the "common school fund," the "literature fund," the "United States Government deposit," etc., and other funds, and yet no representation is made in the published report as to these. The charter provides (Sec. Io66) for the sale of supplies not needed and not to be used, and for the application of the money so received for current use to the special fund of the borough in which the supplies are sold. The only representation of revenues accruing to the schools is under the term and title "appropriations" - which should not be regarded as coterminous with "revenues."

All expenses of the board must be paid by warrant, and this warrant must be reduced to controlling record; therefore, the records and report of the Board of Education and the city comptroller should be in agreement. From an examination of the two reports, it will be found that in the general financial statement for the year end-

Lack of harmony with statements of comptroller ing December 31, 1902, there is scarcely an item of financial summary in agreement. Nor are the general balances the same. Only four items of the general summary of the "special school fund," for example, are in accord, whereas fiftecn of them are out of accord. The balance of appropriations remaining unexpended as represented by the Board of Education is $\$ 380,109.49$, while according to the published report of the comptroller for the same date the balance is SI,531,947.78.

Without attempting to do more than illustrate the character of showing that might be made in a final summary exhibiting relations of administrative economy, and not even attempting to bring the sub-titles into harmony with the existing institution, the following suggestion is offered: 
Comparative Financial Statistics

I. Statistics Showing Relations of Economy -

EXPENSES INCURRED

General Administration:

Salaries and Wages:

Board of Education and General..

Department of Supplies.........

Superintendent of Buildings.......

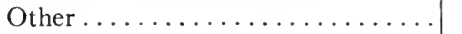

Supplies .................

Miscellaneous General ...........

Total General Administration .. SuperintendeNCE ANd INstruction:

Salaries and Wages:

City Supt., Asso. City Supts., Dist.

Supts., etc. ............

Teaching Staff:

Day Schools:

Training Schools

High Schools

Elementary Schools.........

Evening Schools .............

Vacation Schools and Recreation

Centres......................

Total Salaries and Wages...... Educational Supplies:

Text-books ..............

Printing . . ..............

Blank Books and Paper..........

Stationary ................

Libraries . . . . . . . . . . . . .

Miscellaneous ...............

YEAR

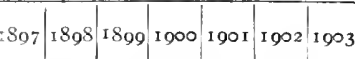

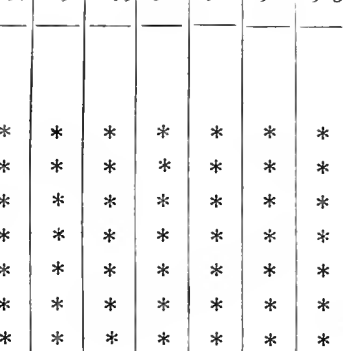

Total Educational Supplies

* Information lacking. 
Comparative Financial Statistics

I. Statistics Showing Relations of Economy EXPENSES INCURRED - Continued

\begin{tabular}{|c|c|c|c|c|c|c|c|}
\hline & \multicolumn{7}{|c|}{$Y_{\text {EAR }}$} \\
\hline & 1897 & 1898 & 1890 & 1900 & 1901 & $190_{2}$ & $\left.\right|_{1903}$ \\
\hline SUPERINTENDENCE AND INSTRUCTION: & & & & & & & \\
\hline $\begin{array}{r}\text { Cost of Lectures } \ldots \ldots \ldots \ldots \ldots \ldots \\
\text { Total Superintendence and In- } \\
\text { struction } \ldots \ldots \ldots \ldots \ldots \ldots\end{array}$ & $*$ & * & * & $*$ & * & * & * \\
\hline BuIlding Operation and Mainte- & & & & & & & \\
\hline $\begin{array}{l}\text { NANCE: } \\
\text { Operation: }\end{array}$ & & & & & & & \\
\hline $\begin{array}{l}\text { Salaries and Wages } \ldots \ldots \ldots \ldots \ldots \\
\text { Supplies: }\end{array}$ & * & * & $*$ & * & * & * & $*$ \\
\hline Fuel and Light $\ldots \ldots \ldots \ldots$ & * & * & * & * & $*$ & * & * \\
\hline Janitors and Cleaners......... & $*$ & $*$ & * & * & * & * & * \\
\hline 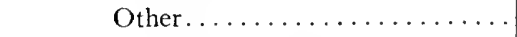 & * & * & $*$ & * & * & * & * \\
\hline Total Operation .......... & $*$ & * & $*$ & * & * & * & $*$ \\
\hline Maintenance (including depreciation) : & & & & & & & \\
\hline Grounds................. & * & * & * & $*$ & * & * & * \\
\hline Buildings ............. & * & * & $*$ & * & * & * & $*$ \\
\hline Furniture and Fixtures ......... & $*$ & $*$ & $*$ & * & * & * & $*$ \\
\hline School Books and Libraries....... & * & * & $*$ & * & * & * & * \\
\hline Apparatus and Machinery ....... & * & $*$ & * & * & * & * & $*$ \\
\hline Other $\ldots \ldots \ldots \ldots \ldots \ldots \ldots$ & * & * & * & * & * & * & $*$ \\
\hline Total Maintenance ........... & * & * & $*$ & * & * & * & * \\
\hline Total for Operation and Maintenance & * & * & * & * & * & * & * \\
\hline Total Expenses Incurred during Y'ear... & $*$ & $*$ & * & * & * & * & * \\
\hline
\end{tabular}

* Information lacking 
Comparative Financial Statistics

II. Statistics Showing Relations of Economy-Revenues ACCRUED.

DEpt. Estmates for the Ensuing YeAr, $\$ 226 \ldots \ldots \ldots \ldots \ldots \ldots \ldots . \ldots \ldots$
Property Basis For APPORTIONMENT AND Appropriation fOR SCHOOLS, $\$ 1064 \ldots \ldots \ldots \ldots \ldots \ldots \ldots \ldots \ldots \ldots$

Min. Amt. of School Approps. under THE LAW, $\$ 226 \ldots \ldots \ldots \ldots . . .$. Budget as Prepared by the Board of Estimates and APPORTIONMENT, $\$ 226$

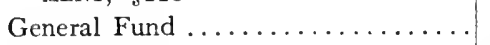

Special Fund...................

Total......................

REVENUE FROM TAXATION AS APPROPRIATED AND APPROI'ED BY BOARD OF ALDERMEN, \$226.

General Fund

Special Fund

Total....................... Aliount Accruing from the State AND OtHer Funds:

Com. School Fd. Cons. IX, $\$ 3$ and Statistics ..................

Liter. Fd. Cons. IX, $\$ 3$ and Statistics U.S. Gov. Deposit, IX, $\$ 3$ and Statistics Other Revenus Accruing During the YEAR:

Sale of Supplies for Benefit of Sp. Fd., $\$ 1066$

Miscellaneous

Total Rev. Accruing for Fiscal Year

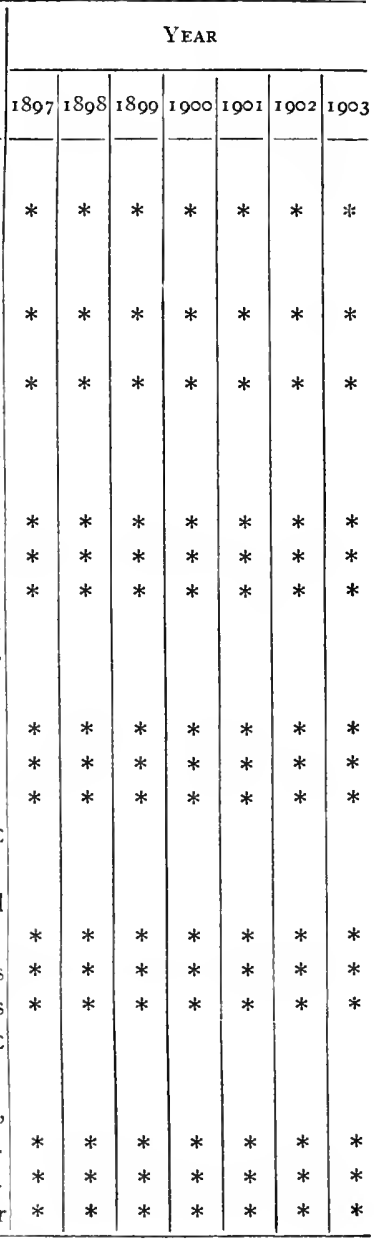

* Information lacking. 
Comparative Financial Statistics

II. Statistics Showing Relations of Economy - Revenues ACCRUED - Continued

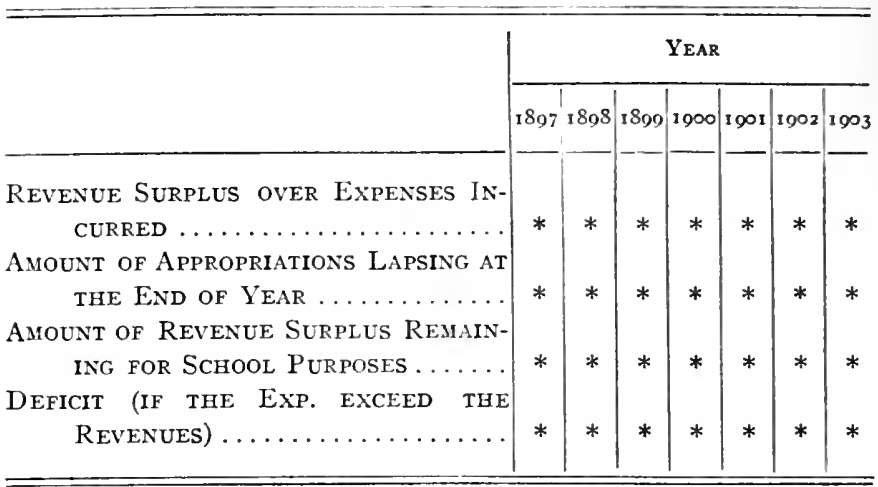

* Information lacking.

III. Statistics Showing Relations of Economy - Comparison of Sertice Rendered to Cost

Average Cost of General AdminisTRATION PER PUPIL PER YeAR:

Bd. of Education and Gen. Officers. .

Administration of Dept. of Supplies. .

Building Superintendence .........

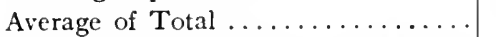

Average Cost of Superintendexce

AND INSTRUCTION PER PUPIL PER

YEAR:

Superintendence .............

YEAR

\begin{tabular}{|c|c|c|c|c|c|c}
\hline 1897 & 1895 & 1899 & 1000 & 1001 & 1902 & 1003 \\
\hline & & & & & & \\
& & & & & & \\
$*$ & $*$ & $*$ & $*$ & $*$ & $*$ & $*$ \\
$*$ & $*$ & $*$ & $*$ & $*$ & $*$ & $*$ \\
$*$ & $*$ & $*$ & $*$ & $*$ & $*$ & $*$ \\
$*$ & $*$ & $*$ & $*$ & $*$ & $*$ & $*$ \\
& & & & & & \\
& & & & & & \\
& $*$ & $*$ & $*$ & $*$ & $*$ & $*$
\end{tabular}

* Information lacking. 
III. Statistics Showing Relations of Econony - Comparison of Service Rendered to Cost - Continued

Average Cost of Superintendence and INSTRUCTION PER PUPIL PER Year: Teaching Staff :

Day Schools :

Training Schools for Teachers.. High Schools ................

Elementary Schools ..........

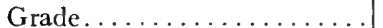

Manual Training ..........

Nautical ..................

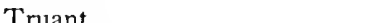

Evening Schools..............

Recreation Centres ....................

Evening and Vacation Schools to be

Reduced to Regular Pupil-day

Standard...............

Average Cost of Lecture per Pupil per

Hour ....................

Average Cost of Play Grounds per Pupil

per Year .................

Average Cost of Building Operation and Maintenance Per Regular PupIL-DAY :

Operation :

Salaries

Supplies

Maintenance :

Grounds

Buildings

School Books and Libraries.......

Apparatus and Machinery ........

Other ...................

Total Operation and Maintenance...

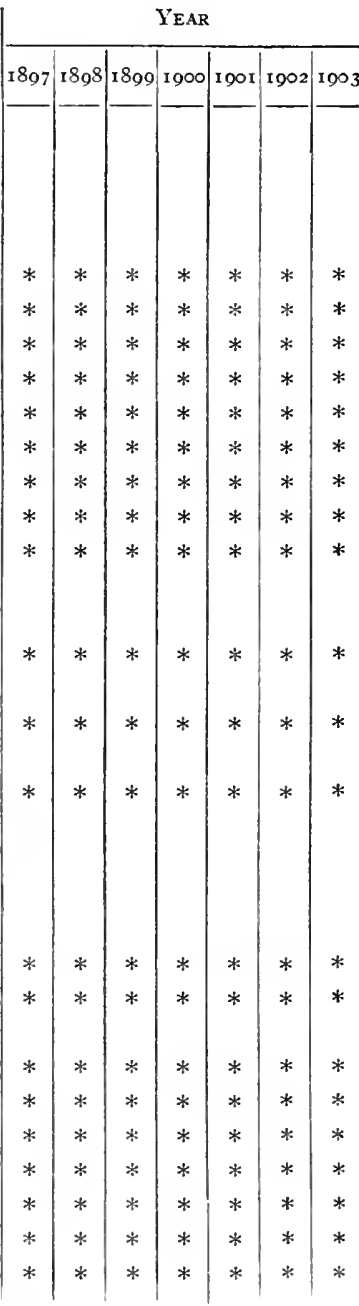

* Information lacking. 
In offering suggestions as to schedules for final summaries of relations of economy, the writer is aware of the fact that no definite formulation could be made for statistical representation of results except at a very large cost

No additional cost if books are kept to give results wanted

to the department, unless the accounts of the department be kept in such a way that the footings of controlling items might be drawn from the books themselves without recasting and without statistical research. While from the character of the report made it may be inferred that the several categories of information suggested might not be readily answered from the books, the conclusion is ventured without fear of controversy that a report containing a statistical statement having reference to the relations of economy here indicated is necessary as a means of enlightening the public and giving to the administration a basis for more intelligent control.

In the report of the Board of Education little or no attempt is made to give any data with reference to financial relations of proprietorship. In justification of this, the fact may be urged that the board is simply an administrative trustee, while under the charter (Sec. I055) the No statement proprietorship of school properties is in the of assets and city of New York. On the other hand, liabilities the board under the same statute, being made trustee for these properties and being the custodian by whom the properties are held, is in duty bound to render to the city of New York, the cestui qui trust, a report of its trusteeship. The published document under review being made for the purpose of representing the board in all of its relations, proprietary assets and proprietary liabilities of the city on account of its schools might properly be exhibited in its financial statements. 
Without this, many important school relations may not be understood. Even if such a report were exhibited by the comptroller of the city of New York, still it would be proper for the department to include as a matter of completeness a showing of assets and liabilities. Still more imperative is such a demand when no well-digested and classified statement is found in other reports.

The general administrative needs for the keeping of asset and liability accounts are two: (I) That the data may be at hand for determining whether adequate allowances are being made for expenses to keep the properties in repair and to maintain the educational plant, thereby protecting the city against future expenditure for past use, and (2) as a means of recording the fidelity of agents Uses to be into whose hands funds and properties made of such are placed for use and safekeeping. Other statements incidental relations may be shown. For the purposes of the board, the city chamberlain may be considered as a fiscal trustee. For the purpose of obtaining the revenue necessary to carry on schools the Board of Estimate and Apportionment and the Board of Aldermen may be considered as agents who have a duty to perform; guide to judgment as to whether they have complied with the law and exercised proper discretion can come only from a complete financial statement. All funds belonging to the schools and which are to be administered by the Board of Education are to be kept by the city chamberlain and disbursed by him. The report contains no such information as will show whether either the city chamberlain or the board have properly performed the duties imposed by law in making provision for school revenues and dispensing school funds. Again, for the purpose of obtaining the funds provided under the revenue measures above referred to, the several departments of government 
having charge of the collection of taxes, the collection of funds apportioned to the city by the State, etc., stand in fiduciary relation. No showing is made as to these. Quite an extended showing is made of the work of the Department of Supplies, but no classified or systematized result is given which will bring these into comparative relation, or which will exhibit to the public official fidelity.

Again attention is called to the fact that this communication is based on an examination of the report of the Board of Education, and of the law under which the schools are operated; it does not assume any knowledge either of accounts kept or of peculiar conditions existing, all of which must be brought to riew before arriving at a final result. The criticisms and suggestions made proceed, rather, from a consideration of the purpose of a report in a public corporation of such size as to make a public statement necessary, and of the duties of officers to give an account of their stewardship. Nor is it to be said that the officer is exonerated from a charge of nonfeasance because the public have not made their demands felt in such a way as to compel attention. A statement that a stockholder does not read a report made is no reason to be urged by an officer for not making the report. Conclusion But leaving the public demand for information entirely out of the question, the duty of an officer to himself and to all other officers and administrative agents to lay before each other such a digest of activities and results obtained as a basis for the exercise of the best discretion in directing the affairs of a great corporation is sufficient reason for an intelligent and comprehensive report. At the present time much discussion is current as to the adequacy of appropriations made to maintain the schools; but how can the Board of Education complain at a reduction in their estimates of 
financial needs if no report is made which would lay the basis for intelligent opinion as to service and service requirements? For a proper consideration of any aspect of administration, a report which embodies an intelligent statement of all the essential facts is necessary. And in making such a report the criterion as to form and content must be the ends for which the branch of the service exists. A report which conforms to this standard, which shows the manner in which the administrative purpose is complied with, will answer both the public and the corporate needs. This is not a purely academic question. In municipal government the demand of the time is for increased efficiency. The impotence of the past has been largely due to lack of well-classified and well-digested information. Given this in the form of published reports, and the largest and most complicated municipal corporation may lead in measures of administrative reform. 


\section{CHAPTER XVIII}

Accounting Methods of the Department of EduCATION OF THE City OF NEW YORK ${ }^{1}$

THE books and records of account of an institution or department must necessarily be determined by its organization and purpose. The Board of Education is, by law, created a distinct governing body and, as such, is made to "possess the powers and privileges of a corporation." As a distinct corporation it is charged with the care and the control over "all properties, real and personal, that now, or hereafter, may be acquired for school or educational purposes, except the State Normal School at Jamaica"; also "all properties, real and personal, purchased for school or educational purposes with any school moneys whether derived from the issue of bonds, or derived by taxation in the city of New York."

Character of organization

To the Board of Education is also given "the management and control of the public schools and of the school system of the city, subject only to the general statutes of the State relating to public schools and public institutions." With the exception of ccrtain trust estates, the title to the property so controlled or operated, however, is rested in the city of New York, and the Board of Education as a depart-

' Report submitted to a special committee appointed by President Tifft of the Board of Education and later in revised form to the Committee on Accounting and Statistics of the Mayor's Advisory Commission on Finance and Taxation. 
ment of the city government is charged with the operation of the properties and is made responsible for the economical management of its schools.

Under the laws of the State, and under the charter from which the Board of Education derives its power, "the corporation" stands in a double accounting relation. (I) Deriving its funds from the city through the Board of Estimate and Apportionment it is responsible for a fund accounting to the city in the manner and according to the forms prescribed by the comptroller. (2) As a distinct corporation it should have an instiAccounting requirements tutional accounting of its own, setting forth its own assets and liabilities, its expenses and its revenues, in other words, it should have a system of accounts which will enable the board intelligently to direct the operation and management for which it is responsible as a trustee. Without such accounts the corporation is not in a position to protect the properties and equipment under its control against waste and depreciation; without such an accounting there can be no proper basis for estimates of supplies; neither can there be such a control over the several officers and agents of the board as will hold them accountable for the funds, supplies, or other materials which come into their hands. Unless the liabilities of the board were set up in the form of accounts there is no basis for determining what are the obligations of the board, or what balances remain unencumbered in the several funds appropriated to its use; unless there be a strict accounting for expenses incurred there is no basis for the exercise of judgment with respect to efficiency or economy of management in any of its many business operations. In fact, from the point of view of business management the Board of Education is so far removed from the details of administration that a complete asset 
and liability accounting and a complete expense and revenue accounting is as essential to intelligent administrative direction as is such an accounting necessary to any active corporation charged with the economic operation of a large business and the faithful account for trust income and resources.

A list of current books of account furnished by the auditor of the Board of Education is as follows:

(a) 8 Voucher books.

(b) I General journal.

(c) Sundry appropriation ledgers.

(d) Sundry bond ledgers.

(e) I Special or trust fund ledger.

In this list of books of account there is to be found no general ledger, in a sense that such a term is customarily used - i.e., there was no book or books containing accounts showing assets and liabilities, income and expenses, except such liabilities as may be found in what is called the "bond ledger," etc., and such categories The accounts of expense as are found in the Appropriation kept by the board

Ledger. The accounts as kept are in a form appropriate to financial control by the comptroller, but are not in form designed to obtain information as a basis for administrative judgment with respect to operation of either the buildings or the schools. Neither do they give a proper basis for the control of construction. They give no adequate control over properties and supplies. All of the books of general account above referred to, as indicated by the lists and exhibited by the auditor, are in the nature of books of general account, subsidiary to and controlled by the comptroller of the city of New York. The bureau of audit of the Board of Education, therefore, may be said to have complied with the legal requirements of accounting to the city for funds 
obtained through appropriation, but so far as could be ascertained the board as a separate and distinct corporation has no system of accounts of its own - i.e., no general controlling books which will enable it to determine its assets, its current liabilities, or its true expenses and operative cost, the economy or efficiency of management for which it is responsible.

There are kept by the auditor certain registers and memoranda from which it is attempted to get at some of

Collateral

records

the administrative results which should be currently obtained from a system of operative account. A list of such registers and memorandum books furnished by the auditor is as follows:

(a) Claims registers.

(b) Pay-roll registers.

(c) Claimants' ledgers (registers).

(d) Contract registers.

(e) Insurance registers.

(f) Register of liens and assignments.

(g) Lease book.

(h) Rent book.

(i) Record of checks canceled.

(j) Record of sites in course of acquisition.

(k) Books showing appropriations - building committee.

The foregoing registers or records, however, are not in a true sense subsidiary to controlling operative accounts of the board as a distinct corporation. In a number of instances they are not footed and closed into general ledger accounts. Being thus uncontrolled, there is no direct accounting method for readily determining whether the results obtained or shown on these registers are accurately stated, except as control is obtained through the 
accounts subsidiary to the books of the comptroller of the city of New York.

As a means of obtaining statistical exhibits of data pertaining to expenses and of satisfying the demands of

Financial statistics committees for information of this character, various books or tables of "analysis" are kept. These books or tables are listed by the auditor as follows:

(a) Analysis - general school fund.

(b) Analysis of janitors' salaries.

(c) Analysis of salaries of officers, clerks, and other employees.

(d) Analysis of salaries of inspectors, draftsmen, etc.

(e) Analysis of the incidental fund.

(f) Analysis of fuel fund.

(g) Analysis of repair account.

(h) Analysis of printing bills.

(i) Record of the supervising and teaching force.

In many instances these analyses, in so far as they register a true statement of classified "expenses incurred," have been obtained by indirect statistical methods instead of being taken directly from general or subsidiary ledger accounts of the board. To a considerable degree, however, they do not correctly state "expenses incurred." They are rather a recapitulation of cash expenditures for different classes of objects, as taken from the voucher records subsidiary to the office of the comptroller, and do not correctly state the "expenses" for any particular period. For example: The analysis of the fuel account showed the amount of cash paid for supplies in the nature of fuel during a particular period. In the office of auditor, however, there is no attempt made to show how much fuel has been used. If we are to obtain a comparative statement of expenses of operation of the different buildings, 
when coal is purchased and stored in large quantities, the fact that the board buys a thousand tons of coal for school No. I, and only five hundred tons for school No. 2, is no reason for setting up the cost of this coal as an expense of the year in which the purchase was made. The administrative situation may be that school No. I has burned only five hundred tons, and school No. 2 has burned one thousand tons. So long as the coal is on hand it is not expense, but is in the nature of an asset.

In determining the cost of operating a building, it is only such amount of fuel as is burned within a given time that is chargeable to the expenses of that period. For the purpose of administration, the expense accounts should, therefore, show the amount of coal burned. As a matter of fund accounting, it is true that the board should report to the comptroller through its audited

False basis for expenses vouchers the amount of coal purchased; it is this latter accounting only that was kept by the auditor, the same information being obtained by him that is required by the comptroller to be reported to the board. To obtain an accurate view of the fuel expenses of each school as a basis for judgment as to economy of administration would require only that a fuel stock account be adjusted by inventory; this seemed not to have been done - in fact, there was no provision in the scheme of accounting for obtaining an administrative accounting for the several classes of operation and expenses for supplies used. By taking the administrative expense data from requisitions on the supply department, instead of setting up the cost data from invoices, true expense accounts might be set up with each school for the several classes of supplies. This would give an accurate basis for administrative judgment both as to supplies on hand and as to materials used, and this might be done with less 
clerical work than is at present involved in the keeping of the accounts and making up the statistical reports required.

In defense of this method it has been stated that the analyses furnished are close enough for all practical purposes. But at the same time, the auditor admits and openly states that his staff is constantly involved in making special investigations and rendering special reports which should be obtained currently from the accounts Information themselves. This is the chief purpose for not taken from which the departmental accounts should be the accounts kept. Accuracy of analyses and statements with respect to administrative expenses, as well as financial results, is fundamental to administrative accounting. Principles of administrative accounting seem to be applied to no part of the records in the office of the auditor, except in so far as they reflect the dealings of the board with the city chamberlain as controlled by the city comptroller.

THE CHARACTER OF DATA ON WHICH THE ADMINISTRATION MUST RELY

In default of a system of controlling accounts in the office of auditor showing the true financial condition and the true expenses of the board as a distinct corporation, the sereral committees having charge of such portions of the business of the board as may be assigned to them Memoranda must rely largely on the books and memokept by bureaus randa kept in the several bureaus through which the business of the board is conducted. For cxample: It was stated by the chairman of the Committec on Supplies, that when this committee desires to know the amount of orders outstanding against a certain appropriation as a means of determining what amount 
of a particular fund is still unencumbered or available, the information cannot be obtainable from the Bureau of Audit but must be had from memoranda kept by the Bureau of Supplies.

It is further stated that there is no account in the general books of the department showing amounts to be reserved to cover contingent liabilities on orders given, although the information is furnished to the auditor for setting up such a reserve. The law governing the comUncontrolled records mittees and officers, charged with making purchases, requires that no orders shall be given in excess of the amount appropriated. For information as to orders outstanding, or the amount of the fund that is encumbered by such orders, we are informed, reliance must be on memoranda kept outside of the bureau of audit, this memoranda being uncontrolled by the auditor.

Again we were informed by a member of the Committee on Sites that if they desire to know what is the contingent liability or encumbrance on the funds set aside for the purchase of sites, they must obtain this knowledge, if at all, from an uncontrolled register. Even this sites register did not exist until after the present investigation Incomplete was begun. By several members of the data

board we were informed that for information pertaining to assets, current liabilities and many forms of expenses incurred, the president of the board and the chairman of the various committees must rely on registers, which are uncontrolled by general ledger accounts, many of which registers are not kept in the office of the auditor. Instead of getting information from the accounting department it would seem that the directing heads of the Board of Education are compelled to ferret out the places where memoranda are kept 
designed to supply the several departments with information needed in the conduct of their business, such information not being available in the Bureau of Accounts.

\section{LACK OF UNITY IN THE SYSTEM}

The purpose of the school system is to educate. As a means to this end there is provided a staff or corps of educators, and physical equipment and supplies; both are necessary to carry on the work. In the organization of the institution the charter has provided that all of the affairs of the public schools shall be placed in the hands and under the control of a corporation known as the Board of Education. The charter further provides that the corps or staff of instruction shall be administered by

Division of responsibility

a city superintendent, and that the administration of the physical equipment shall be divided between two bureaus; the first (the superintendent of buildings) having charge of the buildings or permanent equipment, and the second (the superintendent of supplies) having charge of the furnishing of those educational materials and supplies currently used or consumed. Each of these three departmental heads has a specific function to perform; all of them, however, are subsidiary to the controlling administrative purpose - education - which is under the directive management of the board.

The efficiency with which the board is able to organize, equip, and direct an institution conducting over five hundred distinct educational plants, carrying on various classes of instruction and having differing physical educational requirements involving annual disbursements exceeding twenty-five millions of dollars, depends on the installation of a system which will bring each of these 
various departments and each of the educational activities Lack of central within the knowledge of the board. The administrative records kept by the several departments or purpose

bureaus of the board have not been installed with reference to a central and administrative purpose.

The administrative work of the board has been largely delegated to committees. These committees have borne no direct accounting or statistical relation to the several bureaus or departments. Generally speaking, each of the departments or bureaus seem to have built up a system of record and statistical analysis to suit its own purpose, having little regard for the interdependence which exists between the several parts of the institution as a whole. The records and statistics of one department, in many instances, may not be used in getting at the results or as a basis for directing the affairs of another bureau

Records of or department. For example: We were one department informed that as a means of effecting econnot cöordinated omy, the department of buildings, under with others advice of competent architects or engineers, has during the last year installed a large number of water heaters, but that owing to the lack of a system which proceeds from a unity of purpose in administration, no information as to the fact that water heaters had been put in came to the knowledge of the Bureau of Supplies until after the Budget for 1906 had been made up, when a request was received that the Bureau of Supplies furnish from four to five hundred tons of coal with which to run these water heaters. The Committee of Supplies having no knowledge of the intention of the building bureau to make such an installation could make no provision for this extra quantity of coal in the Budget of Igo6.

Furthermore there is no provision made by the board for harmonizing or unifying the records kept by the various 
departments or bureaus, there being no central office or bureau in which is brought together this information. As a means of more effectively directing the educational corps, the city superintendent has brought together in his own office much of the information collected by the Bureau of Supplies, the Bureau of Buildings, the Bureau of Audit, etc. This has been made necessary owing to the failure on the part of the board to introduce a central or Difficulty in unified system. Even when each departobtaining com- ment seeks to obtain information for itself, parable facts as does the city superintendent, great difficulty is experienced in getting comparable data for the reason that the records have little unity of purpose, and little central control. The administrative system has proceeded from the departments, or from the circumference toward the centre, instead of being designed and promulgated by the board; in most instances the systems existing in the departments have fallen short of the mark - they have not reached the central office, nor are they available for the general purposes of the board.

\section{LACK OF COÖPERATION}

Without a unified system of administration there cannot be intelligent coöperation between the several branches. Evidences of want of coöperation were many. A few of the many examples coming to our attention are here given. Owing to the failure of the auditor to coöperate, the superintendent of the Bureau of Supplies is required to maintain books dealing with various funds against On the part of which orders are issued, so that the work the Bureau of of the department may, at all times, proAudit

ceed without delay and in accordance with the law requiring funds to be available before an order is issued. Whatever books might be kept in the Bureau 
of Supplies for the guidance of the superintendent, the committee having direction over this department should receive its information from an authoritative source and the books of the bureau should be purely subsidiary to those kept by the auditor.

Another instance of lack of coöperation has to do with the relation of education to supplies. The first intimation the Bureau of Supplies receives that workshops, kitchens, and kindergartens are to be opened (thereby requiring equipment and supplies) comes through the presentation to the board by the Board of Superintendents of recommendation to that effect, without previous conference on financial ability and without regard to budgetary estimates. While the Budget of 1905 was cut On the part of so far as (in the judgment of the Committee the Board of on Supplies) to debar the equipment or Superintendents supplying of any new work-shops, kitchens or kindergartens, during that year the Board of Superintendents continued to recommend the installation of those new activities until formally notified that they could not be granted. Another illustration of the same kind: Although the Board of Superintendents had not presented any plans for such features to the Committee on Supplies when preparing the Budget of 1905 , they carried out plans for the opening of a new evening trade school in the Manual Training High School building, Borough of Brooklyn, which called for many kinds of special supplies not on the list. Another Evening Trade School in the Bryant High School, Borough of Qucens, and still another in the Morris High School Building, Borough of Bronx, was said to have been founded by the Board of Superintendents under similar conditions. The chairman of your committee was told that the first information that the Committee on Supplies of the Board of Education had 
of these acts, and that supplies would be required, was when the requisitions were received in the Bureau of Supplies. The superintendent of the Bureau of Supplies states that he was able to provide the materials requisitioned, but only through shifting his plans and making different arrangements than had been contemplated at the time that the plans were made for the year's business; in order to have the supplies on hand on the opening day, or as near to that date as possible, much of the time of the department was consumed in extraordinary measures for obtaining those things which were not on the list and not available at the time the request was made.

We are informed that it frequently has happened that changes in the course of study made without coöperation between the Board of Superintendents and the Department of Supplies causes undue disturbance and that these changes are made without consideration of the contingent loss or expense involved. In the year 1904, at the request of the Bureau of Supplies, the representatives of the Board of Superintendents furnished the Bureau of Supplies with a list of books lying idle in the schools because of such changes. These represented about I 25,000 volumes. It is represented that had there been coöperation between the Board of Superintendents and the Bureau of Supplies, many of these volumes might have been used instead of books which were Effect on ser- currently purchased while they were lying
vice rendered idle; that upon the information thus furnished the Bureau of Supplies was able afterwards to utilize a large number of the books thus discovered, saving the board a proportionate amount in expense for the purchase of new books. In the demands made by principals for additional appropriations in 1905 , the state- 
ment was frequent that the additional appropriations were needed by reason of changes in the course of study rendering many of the books on hand useless. So many were these applications that the principals were asked for a list of books laid aside because of changes in the course of study. This notice was sent out October 6, 1905. A compilation of the reports received up to October 20 shows that there were sixty-two thousand volumes thus affected.

A further illustration of lack of coöperation between the educational and supply branches of the board is found in the provisions made for the opening of workshops in Public Schools 15, 9I, and II2. For carrying on the educational work the organization had gone so far as to have teachers appointed, but there were no supplies provided and no information given to the Bureau of Supplies that these would be needed until actual requisitions were received. On receipt of this request, the Bureau of Supplies, pursuant to the duties imposed upon it, was required to hold up the requisition long enough work of to determine whether the teachers had schools ham- been appointed. Such information being pered received, the Committee on Supplies then ordered that the bureau furnish to these work-shops reduced quantities in order to keep the teachers from lying idle and the plans made by the Board of Superintendents from becoming inoperative. The opening of work-shops and other educational functions without notice even of intention given to the bureau upon which falls the burden of supplying the materials necessary to its successful operation does not seem to comport with efficient administration nor with any intelligent scheme of control. The action above indicated is reported as having been taken by the Board of Superintendents notwithstanding the 
fact that the Committee on Supplies had notified the Board of Superintendents that on account of the appropriation allowed in 1904, there would be no funds available for new work-shops and kitchens. Examples might be multiplied. The above illustrations are given simply to call the attention of your committee to the nature of this lack of coöperation and to the manner in which it hampers the work of the bureaus and stands in the way of effective direction by the board.

\section{DEFECTS IN CLASSIFICATION}

For the purposes of statistics and accounting, classification means that things similar or related administratively shall be brought together or counted as within one class. In the general accounts and statistical summaries these several similar classes may be brought together in such manner that the institution may be intelligently viewed as a whole. Both of these processes are necessary to intelligent thought concerning an institution having as many different activities and departments as the Board of Education. If it is desirable to know the numbers of children attending school by ages it is necessary to classify the children in each of the schools according to age and then to coördinate the similar classes of the various schools as a means of informing the board and all persons connected with or interested in the work how many children there are of a given age attending the public Advantage of schools in the city of New York. These uniform clas- children being so classified, then other sifcation classified information such as courses of study given, ages by grades, graduations, failures to pass examinations, cost of study, etc., may be related. But the ability to coördinate depends on uniformity of classification, coöperation between those in charge of the several 
schools and divisions, classification within the school, and a central bureau or office for the collection of the facts to be coördinated. This applies to all information, physical, operative, or financial, which is needed, either for the guidance of the superintendents, for the information of the several bureaus, or for intelligent direction by the boards and committees of the board.

As a means of thinking intelligently about the question Sites of sites a classification of the physical data is necessary in order that operative and financial data may be understood. The board may wish information of the following kind:

(I) Sites for administrative purposes:

(a) Location.

(b) Size:

(I) Space occupied by building.

(2) Space not utilized.

(c) Ownership:

(1) By city.

(2) Leased.

(2) Sites for purposes of instruction:

(a) Location.

(b) Size:

(I) Space occupied by building.

(2) Space occupied by playground.

(3) Space of driveways and approaches.

(4) Space not utilized.

(c) Ownership:

(I) By city.

(2) Leased.

If such information is desirable, it should be indicated by the board and a classification of data presented which will require all bureaus and departments to so organize the operative and financial data coming within the scope 
of their duties on such lines that these may be correlated; assuming that the above indicated physical statistics pertaining to sites were desirable, then the financial statistics, building statistics, etc., should be so classified as to enable the board to utilize them for their own information.

Again the board, its committees, and the several officers Buildings of administration have to deal with buildings. As a basis for administration some such information as the following might be considered advantageous:

Buildings:

(I) For administration:

(a) When built.

(b) Character of structure:

(I) Wood.

(2) Brick.

(3) Stone.

(4) Combination (wood, brick, or stone).

(c) Number of stories, including basement.

(d) Number of rooms:

(I) For offices.

(2) Assembly halls, etc.

(3) For vaults and storage purposes.

(4) For mechanical plant.

(5) Other rooms used.

(6) Rooms not used.

(e) Cubic space:

(I) For office rooms, (I) total; (2) number rooms, (3) per cent whole.

(2) Of assembly rooms, etc. (I) total; (2) number rooms, (3) per cent whole.

(3) Of library rooms, (I) total; (2) number rooms, (3) per cent whole. 
(4) For mechanical plant, (I) total; (2) number rooms, (3) per cent whole.

(5) Other rooms used, (I) total; (2) number rooms, (I) per cent whole.

(6) Rooms not used.

(f) Area:

(I) Of foundation.

(2) Floor space.

(3) Exposure.

(4) Enclosed wall space and ceilings.

(5) Hall areas.

(6) Stair areas (horizontal space.)

(2) For educational purposes:

(a) When built.

(b) Character of structure:

(I) Wood.

(2) Brick.

(3) Stone.

(4) Combination.

(c) Number of stories, including basement.

(d) Number of rooms:

(I) For school purposes.

(2) For office.

(3) For library rooms.

(4) For gymnasium or enclosed playground.

(5) Locker and dressing-rooms.

(6) For mechanical plant.

(7) For storage.

(8) Other rooms used.

(9) Rooms not used.

(e) Cubic space:

(I) Of school rooms, (I) total; (2) number rooms; (3) per cent whole. 
(2) Of office rooms, (I) total; (2) number rooms; (3) per cent whole.

(3) Of library rooms, (I) total; (2) number rooms; (3) per cent whole.

(4) Of gymnasium and enclosed playground, (I) total; (2) per cent whole.

(5) Locker and dressing rooms, (I) total; (2) per cent whole.

(6) For mechanical plant, (I) total; (2) per cent whole.

(7) For storage, (I) total; (2) per cent whole.

(8) Other rooms used, (I) total; (2) per cent whole.

(9) Rooms not used, (I) total; (2) per cent whole.

(f) Area:

(I) Of foundation.

(2) Floor space.

(3) Exposure.

(4) Enclosed wall space and ceilings.

(5) Hall area.

(a) Total.

(b) Per seating capacity.

(6) Stair space:

(a) Total.

(b) Per seating capacity.

(g) Light space:

(I) Total light space:

(a) Unobstructed.

(b) Obstructed:

(I) Exterior.

(2) Interior.

(2) Light space per one hundred cubic feet of school rooms. 
(h) Sittings;

(I) Sitting capacity of school rooms.

(2) Actual sittings:

(a) Complete.

(b) Incomplete.

Information of this kind is available to the board if it were collected and classified. With some such classification of the physical data pertaining to buildings, and with financial data so classified that these might be coördinated, the Board of Education might determine what is the rate of depreciation on structures of wood, of brick, and of stone; it might definitely show to the Board of Estimate and Apportionment what is necessary to be appropriated for the purpose of preventing depreciation of the structure; it might also be known what building space has Advantage of been made available for purposes of inclassified in- struction as distinct from administration formation what have been the provisions for offices, for libraries, for gymnasia and playgrounds, for lockers and dressing-rooms, for mechanical plants, for storage and other uses to which buildings are put; the board might also know what have been the provisions made for health; by having the cubic air space and floor space a standard might be established for estimating the economy of heating, ventilating, caretaking, etc.; by having the seating capacity of each room and the actual sittings it might be known whether or not there is any space available for new sittings. From any point of view the classification of data, educational and financial, seems to be defective in that the classification used in one department is not such as to make the information at all times available to the other departments.

Whatever may be the basis of classification it should be applied to the physical, the financial, and the educational 
in such a way that all of these results may be brought to-

Basis of classification

gether. For the information of the board, and to the end of intelligent administration, the classification should be broad enough to answer every question to be asked by the board, by its committees, or by the several bureaus of administration. To attempt to say wherein the classification in any particular bureau is defective would assume superior knowledge as to what the board, its officers, or the public wish to know. That the classification is not uniform and may not be coördinated appears on the face of the records. It also appears that the classification which has been established, in many instances is not used. An example of this is found in the form on which the various principals report to the superintendent.

Looking toward the need for further equipment, one of the questions of primary importance to the superintendent, to the Board of Education as well as the Board of Estimates and Apportionment, is that of sittings. The only way that there may be any intelligent judgment as to sittings available is to get at the sittings not in use by grades. This information is returned by the principals, but it is not regularly coördinated in the department. On inquiry as to how much time it would require for those coördinating the reports of principals to state the vacant sittings by grades, we were informed that it would be very difficult to do in the present condition of the records, but that if this information were drawn off currently at the time the reports were analyzed it would be a very simple matter and would require little or no additional clerical force.

Under the present method of obtaining information, it very frequently happens that a special statistical investigation is necessary, to lay before the board or before the 
public, information which should be currently stated on the face of the records, and which should be so stated if the character of the information to be obtained were made a subject of consideration and coöperation betwcen the board and the several departments. As has been before stated, defects in classification and coördination are also found in the accounts. In the office of auditor the general journal and the several registers are books of classification. In many instances these do not have in mind the character of information required for administrative purposes, as a result of which a large part of the time of the clerical and supervising staff is talien up in the preparation of special reports; in fact, this was one of the serious burdens complained of by the auditor.

It being assumed that the purpose of the inquiry on the part of the mayor in the appointment of an advisory commission is to determine what is necessary to obtain friendly coöperation among the several bureaus and committees of

A restatement of conclusions a department and to bring about an improvement in the system of accounts and administration such as will give to him an intelligent basis for control, without going into further details, the defects in the records and administrative methods of the board may be summarized as follows:

(I) The Board of Education as a separate and distinct corporation seems to have no well-devised system of general accounts reflecting its corporate financial relations its assets, its liabilities, or administrative relations of current expenses - such accounts as are kept being in the nature of accounts with funds controlled by the comptroller of the city of New York.

(2) The books and records kept by the several bureaus and committees for the guidance of administrative heads, and for the information of committeemen in many in- 
stances seem to be uncontrolled by general accounts kept in the Bureau of Audit.

(3) Although the Board of Education as a corporation is by the charter made the highest authority and given control over all the properties and affairs of the public schools, including the appointment of a superintendent of school buildings, a superintendent of school supplies, a city superintendent of schools, a supervisor of lectures and one or more auditors, and the several departments or bureaus of administration are by law made subordinate to the board, these bureaus and departments have been operated and controlled by the several superintendents or heads in large measure as if they were independent of the supreme control of the board, and as if they were not interdependent in obtaining educational and administrative results.

(4) Proceeding on these lines departmental or bureaucratic methods have dereloped without central control by the board and without intelligent control by the general government, each superintendent of bureaus or each committee following its own designs, as a result of which the statistical forms and records have little unity or consistency of purpose; there seems to have been no common basis for classification, and the data obtained by the one department or the other in many instances could not be utilized to advantage either as a basis for intelligent control by the board, or for accurate and comprehensive report to the public.

(5) The reports made by the several branches of the service to the board, and by the board to the public, are inadequate and do not present information in a form to permit the board to exercise discretion in its acts or for the public to properly estimate and appreciate the character of serrice performed by a department of government upon whose efficiency and economy depends the future welfare of the community. 


\section{CHAPTER XIX}

Administrative NeEd For ACCuRaCy and Uniformity IN THe Accounts and Reports of Hospitals ${ }^{1}$

THE underlying thought in the subject assigned is not new to the medical profession. The question is whether or not in hospital operation physicians should not apply the same methods of research, and have before them the same accurate basis for judgment, that you have in operating on and prescribing for your patients. Applying to the problem of administration the nomenclature of medical science, we may regard the hospital as having its own habitat, its anatomy, its physiology, and its pathology. Anatomically the hospital is a form of corporate body that, through centuries of adaptation, has evolved attributes as common in kind as humanity itself, as uniform as the functions of the human body whose physical The hospital sufferings the hospital is designed to relieve. as a subject The functions common to all hospitals are of analysis general administration, professional service, ward service, dietary service, provisioning, housekeeping, laundering, and the general care and maintenance of buildings and hospital equipment. These functions and the organic parts adapted to their performance being common, all activities and all data pertaining to them may be classified and summarized, and thus reduced to a common basis for scientific thought. It is of course to be noted

${ }^{1}$ Read before the Medical Society of the County of New York, February 26,1906 . 
that many special characteristics have been developed, such as differences in supervising staff, in professional staff, in ward organization, in dietary arrangements, the addition of free dispensaries, the organization of out-patient departments, ambulance service, and other specialized adjustments in the nature of adaptations to conditions; all these must be reckoned with as a matter of institutional survival or corporate growth.

The study of function in its relation to corporate organism is the physiology of our subject; the exercise of judgment as to what function is normal and what is abnormal, the diagnosis of institutional condition, the giving of administrative direction and the exercise of administrative control - all are premised on the anatomical and the physiological study of the hospital. But this is not enough; abnormality of function must be accounted for before a remedy can safely be prescribed. The administrator must apply the method of scientific research to institutional pathological inquiry. He must be able promptly to get at the organic causes of maladministration and institutional inefficiency. His diagnostic faculties and instruments of precision must be such that he can tell whether the malady comes from a lack of administrative stimuli (symptomatized by inaction and institutional atrophy), or whether it is traceable to a colony of grafters or to some other local parasitic infection.

A science is a body of exact knowledge collected, classified, and coördinated with reference to problems arising Definition of a some common subject of human inscience $\quad$ quiry. As a medical science could not be developed by the study of the anatomy, the physiology, and the pathology of a single individual, so administrative knowledge would be small, to say the 
least, if limited to inquiry with respect to a single institution. Neither can a science be developed by the research of a single investigator. There must be collaboration between many, and as a basis for collaboration there must be a common method of research, a common classification, a common basis for coördination of results obtained in order that each investigator may contribute something to the sum total of exact knowledge with respect to a subject of common interest. Hospital organization and administration has come to be a prominent subject of inquiry. Hospital organization and administration must, therefore, become a specialized science, the making of which is dependent on the combined intelligence and experience of all those who are engaged in this branch of business activity. This end must be reached before we can establish such a basis for direction and control as will meet the requirements of men of professional training.

Viewing the hospital as one of the necessities of modern life, and the problems of organization and administration as a proper subject for inquiry, the practical question is this: How may we go about it to put the art of hospital operation on a scientific basis? As a matter of practice, how has medical science, geological science, physics, chemistry, botany, linguistics, engineering, architecture, law been reduced to a plane of exact thinking? We The scientific have our colleges of medicine, our unistudy of hos- versity departments of geology, of physics, pitals of chemistry, of languages, our schools of engineering, architecture, and law. In these the essential feature has been the association of workers who, by use of a common method of research, have coöperated for scientific results. That we may have the practical question squarely before us, let us assume that there were organized a commission or a bureau of hospital research. 
With such a group of investigators collaborating under competent direction what might be accomplished?

One of the first questions of hospital organization relates to hospital needs. The hospital is the institutional instrument organized for the purpose of providing the conditions best suited to success in surgical operation and medical prescription. As surgery and medicine have become highly specialized, so also has hospital service. The need for hospitals is the need for institutional facilities for the application of specialized remedial aid to the sick and the injured. By humanitarian impulse some one is What may be moved to give. Some one desires to condone by the tribute a fund for the relief of the sick poor. scientific study Shall it be in aid of the medical and surgical of hospitals specialty of tuberculosis, obstetrics, ruptured and crippled, abdominal surgery, eye, ear, and throat, gynæcology, insanity, contagious diseases, or what? The intelligent determination of hospital needs must depend on scientific research.

Having determined that the institution shall take the form of a tuberculosis hospital, the next question is as to location and physical equipment. Generally speaking, the question of location is one which has reference to the convenience of the community to be cared for or to the natural conditions favorable to the remedial treatment to be administered. An institution for obstetrical practice should be placed in or near a crowded quarter which is not already so supplied. A hospital for contagion should be isolated yet within easy reach of the city. A tuberculosis hospital should be so located as to secure the conditions most favorable to physical invigoration and successful combat with localized infection. The interests of medical and surgical science would suggest that benevolence and public expenditure should have the 
guidance of some association or authority competent to advise.

Even more urgent is the need for research and welldigested records pertaining to matters of hospital housing and equipment. The highly specialized uses to which the hospital is to be put require a highly specialized architecture. Assuming that a bureau of hospital research were established, there could gradually be brought together such architectural experience as would add permanently to the social efficiency of bequests and as to the working efficiency of institutions established on private or public foundations.

Before the informative basis for hospital organization is complete, data pertaining to location and physical equipment must be supplemented by exact knowledge with respect to hospital service. How should a corporation be organized to obtain the best corporate results? What should be the corporate powers granted? How should these corporate powers be exercised? What powers should be given to the board? How large a board should be provided? How should it be chosen? Should it be a continuous or a terminating body? What should be the individual and collective responsibility of its members? What powers should be given to officers? How should the official staff be organized? What should be their accountability and responsibility? What should be the departmental organization? What should be the system of administrative control? How shall the professional staff be provided for, and should the hospital be monopolized by the staff, or should it be operated as an institution open to the whole profession for the care of patients under treatment?

These are fundamental questions. Assuming that a Carnegie or a Rockefeller, a Morgan or a Phipps, were to 
consider the endowment of a hospital, to whom would he turn for scientific information as a basis for judgment? Can any single institution, association, or person act wisely on such matters, unless some method is devised for collecting, classifying, coördinating, and reporting the experience of hospitals with respect to questions of hospital needs, hospital location, hospital architecture and equipment, hospital incorporation, and the organization of hospital service.

It will be seen that in all these relations hospital facts bear a close resemblance to what may be called anatomy and habitat. We now come to the physiological side of the subject. This presumes a study of functional activity. Having analyzed and classified the several methods of organizing the general administration, the ward service, the ambulance service, the dispensary, the out-patient department, the dietary and kitchen, the laundry, the What may be housekeeping, the service for maintenance done by the of property, etc., questions of administrascientific study tion centre in the operation of these several of hospital ad- branches or departments. Operative results
ministration

maybe reflected in the statistics and accounts. But before any intelligent opinion can be formed, or any conclusions drawn, there must be a common method employed for the collection of data, a common basis for classification of information adopted, a similar coördination of the classified facts, and a form of report which will enable those reading the results arrived at, to come to a common understanding.

As a means of obtaining such results, a bureau of hospital research would be an invaluable, we may say an indispensable, aid. Without some agency through which scientific coöperation can be maintained, each institution and each investigator is working independently, and hos- 
pital research can never rise to the plane of a science. Whatever be the agency - whether the work be carried on by an independent bureau, a joint commission, a hospital Saturday and Sunday association, or by frequent conferences among hospital superintendents and accountants - certain it is that the operative side of hospital work can never be reduced to an exact science nor a sound foundation ever laid for administrative judgment till some provision is made for coöperation.

Let us assume that through some central agency a bureau of hospital research or a permanent joint commission, the habitat, the anatomy, and the physiology of each institu-

The advantages of a hospital science to the individual institution tion becomes known; more than this, let us assume that through methods of scientific research a compendium of hospital facts were available from which might be drawn conclusions capable of serving as fundamental principles for the guidance of administrators.

The advantage of such information and such guidance to the individual is evident. Is the coal expenditure of a particular institution so large as to become a symptom of institutional irregularity? This at once calls for a diagnosis. Other symptoms are looked for. Is all of the coal received that is paid for? Is the firing economically done? Is the type of furnace one that transmits the heat, or is the fuel wasted through defective or ill-constructed flues? Is the transmitting apparatus of a kind such as will give the best heating result? Are the pipes well jacketed? Let us suppose that all these are answered in the affirmative; what next? Is the ventilating apparatus such as to carry off the heat before it has been effectively used? Do the windows and doors close tightly, Yes? The diagnosis is not yet complete. Is the institution exposed to cold winds? After careful diagnosis this is noted 
as a fact. The remedy is indicated. The superintendent prescribes revolving winter doors and double glazed windows. The prescription is filled at a capital cost of, say, five hundred dollars, and the expense of the institution reduced one hundred dollars per year. By such a thoroughgoing investigation inspired by an indicated and seeming abnormality of function the superintendent is enabled to locate an institutional disease anywhere along the whole line which without standards for judgments would not have been discovered.

By application to well-established standards of efficiency and normality in medical and surgical practice, the superintendent (for example) discovers a symptom of institutional disease in the alcohol bill. Inquiry as to this locates the cause in the use of ninety-five per cent alcohol for rubbing backs. Another symptom of economic weakness is found in the gauze supply. Administrative diagnosis discovers that the surgeons and physicians are careful, but that antiseptic gauze is used by the nurses in cases or at times when unsterilized muslin bandages or towels would serve as well. The expense for supplying food seems abnormal; this may be traced to a lack of responsibility for supplies, permitting petty thievery by servants, to the wasteful use of stuffs, to the serving of high-priced viands to the house servants, to the purchase of provisions out of season when seasonable ones would have the same dietic value, to one or more of a hundred other causes. In every part of the institution the management is improved, and economies may be pointed out by having some basis for judgment that will indicate a pathological condition.

Above all, the administration of an individual hospital depends on the system of control through the accounts. In this hospitals are woefully defective. Like the life 
insurance and other trustee institutions they have failed to appreciate the meaning of administrative control, and What may be the duty of hospital boards to introduce done by the such systems of account which will give it. formulation of
an effective system of ac- method and means of collecting and clascounting con- sifying the financial data, and coördinating trol these data around problems of administration, a central bureau of hospital research can do much to raise the standard of efficiency. Such an agency would prove especially effective in establishing a form or basis for reporting which would give to the public and to benefactors an intelligent account of hospital trusteeship. 


\section{CHAPTER XX}

\section{EleEmosynary Institutions and Accountancy ${ }^{1}$}

The members of this conference may not be accustomed to thinking of philanthropy in terms of accountancy. Dealing with human factors, you have perhaps found little or no interest in figures. Nevertheless, for an apostle of finance it may not be considered inappropriate to say that your sums, whether they have to do with human integers, or with human fractions, must be finally solved by the logic of the counting house. Application is made to the office of philanthropy for relief; you at once send out an agent to take off an individual balance sheet, an individual income-statement, and an analysis of the individual deficit-account. Philanthropy which is not preceded by such an investigation is considered as worse than wasted.

The records from which your data are drawn, are found in the faces, the hearts, and homes of social dependents. The symbols read and interpreted by you are hunger, pain, and disease - the dwarf child, the tear-worn face of the mother, the hopeless and inebriate father. The quantitative and qualitative emblems interpreted and summarized by philanthropy differ from those of accountancy; but the methods employed for obtaining results are much the same. The professional accountant procceds from the point of view of the administrative prob-

' Paper read before the National Conference on Charities and Corrections, May, 1906. 
lem of an institution, and looks toward the individual welfare of the stockholders. The professional philanthropist proceeds from the premise of the social problem, and looks towards the individual welfare of the component member of society. In each case, the remedy is applied to existing conditions only after a careful analysis of results reported. Administrative reform looks toward increasing industrial efficiency; social reform must have in mind an increase of physical, mental, and moral force, that the deficit in the individual income account may be transformed into an earned surplus on the individual balance sheet.

Accountancy has to do with institutional pathology. Philanthropy has to do with social pathology. Having before it ideals of healthful social activity, philanthropy applies concepts of normality to the pathological aspects of social life. The philanthropist, as philanthropist, is not interested in man as individual; he is not primarily concerned with individual insanity or disease; neither does he feel that duty calls him to a consideration of the moral pervert as such. These subjects lie within the professional field of the physician, the clergyman, and the teacher. Those who devote their lives to philanthropy regard temporary incapacity with an eye to the restoration of the individual to normal healthful activity in a society coöperating for common well-being.

But aside from analogy in method and purpose, philanthropy and accountancy have a very direct relation in fact one which requires direct coöperation. In a society like our own, philanthropy must deal through institutions, and organically takes on corporate forms. It has estates to be administrated, and corporate functions to be exercised and controlled. Administrative control is the professional field of accountancy. The ideals of administration by which it is guided are, fidelity, economy, 
and efficiency; it holds itself out as a professional adviser, willing and able to prescribe the methods by which administrative control is to be attained and exercised, in order that these institutional ideals may be realized. It is this, the institutional aspect of philanthropy, to which this paper is especially addressed.

\section{PHILANTHROPY AND CORPORATE TRUSTEESHIP}

The suitableness of corporate organization for philanthropic work is readily perceived from the briefest statement of its characteristics. A corporation is a legal person empowered to receive and hold property for its beneficiaries, but with no power to use or dispose of the same, except through duly appointed agents or trustees; through these, all corporate activities must be carried on. Corporate activities, therefore, are premised on personal fidelity; and corporate estates are protected by rules of law, which hold these trustees to a strict account.

The beneficiaries of a commercial joint stock corporation are persons (or their assigns) who have directly contributed to its capital, in exchange for shares. In order that one or more of the shareholders may not receive an inequitable share of the benefits of corporate association, no one is permitted to control its property or its policy, or to distribute its profits, except those delegated to act in a representative trust capacity for all concerned. A further protection is found in the legal provision that no business may be transacted except by an entirely different set of trustees, known as officers. As has been before pointed out, there are, in such a corporation, three forms of institutional control to be exercised: (I) Proprietary control, exercised by stockholders through the choice of a Board of Trustees. (2) Board control, to be exercised through the appointment of officers 
and through the making of rules prescribing their duties and limiting their powers. (3) Administrative control, to be exercised by those who are charged with the details of the business transacted by the company.

A philanthropic institution differs from a commercial or joint stock company chiefly in this: that the element of proprietary control is wanting. In such a society there are no stockholders, and therefore, no proprietors to whom the trustees are required to report; there is no one by whom the acts of the trustees are to be reviewed before new representatives are elected. Those who have contributed property or funds as a foundation for benevolent work, usually relinquish all beneficial rights in the estate, and leave the management to a self-perpetuating Board of Trustees. Their duty is to direct the affairs of the society and control its officers in the interest of a class of social dependents, for whose relief the society was organized. These beneficiaries have no claims which may be enforced, neither have donors any guarantee that the terms of their gifts and bequests will be complied with, except such guarantee as is found in the integrity and accountability of the trustees.

Without a body of proprietors to call them to account, the trustees of the benevolent society have a much greater responsibility than the directors of a commercial joint stock company. To add to the sacredness of this relation, the corporation itself is made a trustee, with rights to enforce the will of the contributors on one hand, and with a duty to protect the beneficiary interests on the other. By such a trustee, these rights and duties are enforceable in courts of law, but their enforcement depends on accounts and reports which will give to officers and directors, as well as to donors and beneficiaries, an intelligent view of administrative results. 


\section{THE VIEW OF THE PAST}

In the past, corporate trusteeship has been too lightly regarded. It has been customary for religious and philanthropic enthusiasts (as well as for designing promoters) to seek out men of reputation for stool pigeons to sit on corporate boards. This has been done to attract the attention of the benevolent public, and to inspire confidence while soliciting contributions. When asking persons of prominence to accept such positions a definite pledge is frequently given that no demands will be made on their time in attending to the affairs of the society. It has not been uncommon for a single person to hold places on many of such boards, at the same time giving practically no thought to the business of any of them. This is little short of dishonesty. The control of such a society is usually dependent entirely on the personal attention of its trustees. Relying on the sense of duty which should reside in trusteeship, donors contribute to an estate in which they retain no controlling right or interest; and these sacred obligations have been accepted by persons knowing that all general powers of direction and control are in their hands.

Quite as remiss is the man who accepts a position on a Board of Philanthropy as an honorarium - or in order that he may occasionally spend a pleasant hour, and have his name associated with persons who have attained honor and distinction in literature, business, or public life. These motives do not comprehend the first thought of respect for duty and personal integrity; nor do they admit of a more favorable interpretation than the act of one who, being unmindful of his trust, permits his own servants to waste the estate of another that has been left in his care and keeping. 
Another type of corporate infidel is found in the officer who, being in executive position, uncontrolled by his board, - or what is still worse, supported by a self-perpetuating board of his own choice, - comes to regard himself as a proprietor and chief beneficiary of a philanthropy that looks to the public for support. This type is still found in certain educational, reformatory, and charitable corporations. Such an officer spends hours trying to educate the public not to give to individual beggars, but considers himself licensed to beg without feeling under any obligation to take the public into his confidence, or even to render an intelligent account of his stewardship. In response to demands for informiation, he will answer that the trustees have no interest in details, and that the public is not entitled to knowledge with respect to the inner workings of his organization.

\section{A NEW IDEA AS TO CORPORATE RESPONSIBILITY}

The public demand for more light on matters of trust is not limited to life insurance. This craving for facts pertaining to institutions is a manifestation of a general awakening which requires that those holding positions of trust (whether they be officers of government, or of transportation and investment companies, or members of boards and officers of benevolent associations) shall be held to public account. There is a disposition to ferret out the moral pervert and the institutional parasite, whatever be his station in life. Especially is this true in connection with institutions organized in the interest of public welfare. The demand of the time for personal fidelity, for economy of human effort, and for institutional efficiency, applies to the millionaire as well as to the pauper. And these are qualities which require an intelligent basis for the exercise of judgment on the part of 
those in possession of controlling responsibility, whether this judgment be that of citizen, of stockholder, of voluntary contributor, or of the trustees and officers of institutions supported by taxpayers, stockholders, and voluntary contributors.

This new demand comes not from a diminishing standard of individual honesty, as has sometimes been urged, nor by reason of a decreasing sense of personal honor. It comes from the higher ideals of social duty; from the constantly increasing personal responsibilities incident to broader institutional life. In a society so complicated in its fabric as our own, so comprehensive in scope (industrially, financially, and politically), there is an ever increasing need for control - in order that those who work with fidelity for common ends may be protected; in order that economy in group activity may be conserved; in order that personal efficiency may be rewarded and that such as are inefficient may be marked for replacement by those who are able to contribute their share to coöperative production; in order that there may be a proper regard for the larger duties and responsibilities on which institutional growth and general welfare depend.

In a philanthropic institution, such an ideal requires that the employee shall be under the administrating control of the officer; that the officer shall not only keep a complete and accurate account of the administrative activities for which he is responsible, but that he shall also render an intelligible report of the same to the trustees; that the report as rendered shall not only speak in terms of details as to funds received and funds disbursed, but also shall give an accurate measure of the full range of institutional achierements. It requires that the administrative data should be regularly and currently collected through departmental accounts, and reported in such 
manner as to inform the board with respect to the economy and efficiency of functions performed. Going a step further, this new idea as to responsibility requires that the board shall not only assume responsibility for the general direction of the society's affairs, but also make a full report of its activities and finances both to contributors and to the public for whose benefit the institution is maintained.

THE RACE IDEAL OF ACCOUNTABILITY AND CONTROL

Intelligent institutional control presumes administrative knowledge of the minutest details ; it presumes that all judgment and directive action proceeds from such knowledge. Our highest ideal of administrative account and personal responsibility is not the dream of a prudist, nor the dogma of the reformer; it is found in the moral and religious culture which dominates the race. As man has looked out on a universe of countless worlds, he has contemplated the spheres as they swing through millenniums of time and an infinity of space - driven onward by immeasurable force, yet each controlled by other forces which bend their paths and shape their courses in such manner that planets, suns, and satellites move on in perfect order. Considering this magnitude, the complexity of substance, of force, of form (a cosmos so great that it may not be comprehended or probed by instruments of sight), all moving under such complete control that our astronomers may calculate the tides, the eclipses, and other cosmic phenomena with certainty for centuries to come, we have the best race concept of control that is possible for the human mind to grasp.

Following the tenets of religious belief this control is held to be a personal one - our religion centres on personal responsibility of the creature (the servant), to the 
Creator (the master). The power which impels is conceived as Almighty; the hand which controls without mischance - this, the race regards as Omnipotent. But with the concept Omnipotent our notion of cosmic administration is not complete. The hand which shapes and determines the destinies of the universe is conceived to be guided by an Intelligence as great as it is powerful. We call this intelligence Omniscience. Omnipotence! Omniscience! One element is still lacking. Personal responsibility of every creature to a common Creator! These are the elements essential to the race ideal of control and responsibility.

Whatever may be our religious faith, this race concept has in it a very direct bearing on the social problem before us - the great problem of institutional administration. Human association and institutional life, broadening, widening, becoming more complex, is gradually coming to comprehend a wider range of facts. In some of our coöperating groups we have already spanned the earth. Individual intelligence, however, is limited to the senses. To know, we must taste, touch, smell, hear, or see. Our intelligence in institutional control must come through these senses. The possibility of individual direction must depend on the person in command being able to bring the acts of all persons coöperating within the range of his faculties of perception and of reason. Under primitive conditions this was simple - it required no organization other than that provided by nature itself. The one in control was able to hear or see each employee and keep in personal touch with his every act. No intermediate controlling device was necessary unless it be to aid the memory and to lay the foundation for better judgment as comprehended within the wider range of experience. But under modern organic conditions original 
perception must come through others. Its certainty must depend on some intermediate accounting device which will accurately record the acts of every person and give such logical summary of results as will place before the administrator a digest of experience which may be used as premises for highest administrative reason and the best directive control. This fact the philanthropist has not yet fully perceived. He receives millions in funds; he accepts responsibility for the management of large estates; the manager of these funds and estates may be responsible for many agencies and branches which are supported by trust income. In many instances, without feeling it incumbent on him to adopt methods which will enable him to discharge his duties with highest honor or to extend relief to the maximum number within the class whom the philanthropy administered by him is intended to reach. He has not yet come to appreciate the truth that business principles should be applied to the business side of the trust in his hands. 


\section{CHAPTER XXI}

\section{An Agency of Citizen Inquiry - The Bureau of Municipal Research ${ }^{1}$}

ONE hundred and thirty years ago the people of this republic took upon themselves the task of self-government; they incorporated themselves for purposes of public business. In this act of incorporation they decided what agents they would employ and assumed the right to select their own trustees; they executed to their business agents limited deeds of trust, and made these deeds of trust (their charters of government) revokable at will. That the acts of their trustees might be subject to frequent review, they limited their tenure and made A bit of ample provisions for direction and control. Franklin One of the first coins struck by these rephilosophy organized states was designed by that great publicist and revolutionary philosopher, Benjamin Franklin. On its face was portrayed a dial and the rising sun - emblematic of the dawn of a new political era full of hope and promise. The reverse side had for its margin a chain of thirteen links, suggesting need for coöperation and combination for common ends. Within this broad border was the motto: "Mind Your Own Business." As citizens your business is public business. Have you been mindful of it?

In your city is a great water-producing enterprise. It

${ }^{1}$ Memorandum for address before the Real Estate Board of Brokers, New York, February 17 , I 909. 
collects from hundreds of square miles of territory, and distributes to millions of people. From the operation of this plant millions of revenues accrue each year. In this plant many times more millions are invested. You, as citizens, pay this water revenue. You, as citizens, have furnished this capital. The purpose of all this is to maintain a public enterprise which will produce the best, the purest water at the lowest possible cost. This is your business. Are you minding your business?

Around this city are miles of water front. These belong to a corporation of which you are a member. Reaching out to river and ocean traffic are docks and

The citizen's business

piers. You furnished the capital with which these docks and piers were built. The management of these properties, the leases entered into, their operation and maintenance, has been placed in the hands of your trustees. Do you even know whether these trustees have had ordinary facilities for doing business? Do you mind your own business?

The several boroughs of the city are widely separated by arms of the sea, to span which bridges have been built, tunnels constructed, and ferries operated. Many of these are municipal bridges, tunnels, and ferries. They were built at high cost. The bridges are operated and maintained at an annual expense of, approximately, $\$ 1,500,000$; the ferries are operated and maintained at an annual cost of approximately $\$ 2,100,000$; nearly $\$ 900,000$ in excess of revenues. This is your business. What are you doing to mind your own business?

To house your schools, your hospitals, your social dependents, your courts, your police, your firemen, your workmen, your public business offices, between one and two thousand buildings are required; these must be ade- 
quately maintained. To provide the service necessary to the welfare of a great population some sixty thousand employees are retained; these must be paid. To make Incidents of this service effective a variety of equipment corporate must be provided at high cost to the comtrusteeship munity; this must be repaired and replaced. Municipal stables caring for thousands of horses; municipal repair shops employing thousands of men; municipal storehouses containing millions in supplies; annual expenses over one hundred and fifty million dollars; annual receipts and disbursements of nearly five hundred millions; a gross debt that is close to a thousand million; - these are some of the incidents of corporate trusteeship which call upon you as citizens and as beneficiaries of public funds to "mind your own business."

For years you have been guessing at your city debt. Two years past the legality of bond issues has been in question, because you did not know whether the limit Some condi- of borrowing power had been reached. By tions which reason of failure to record contract liasuggest inquiry bilities incoming administrations have been saddled with the debts of past administrations; appropriations and bond funds have been overencumbered; authorizations to spend have been forced; the Board of Estimate and Apportionment have been unable to exercise financial control. By reason of lack of cost data, budgets have been guesses and control over economy and effciency has been an administrative impossibility. Is it thought by you that the conditions which have prevailed in our public affairs are in a measure due to the fact that you have not been mindful of your business? Is the reason why you are interested in hearing something about the Bureau of Municipal Research that you have felt that some organized citizens' agency is needed to provide 
you with the information necessary to make the powers of citizen control effective?

\section{A STATEMIENT OF PRINCIPLES}

If asked to formulate the principles, the plans, the work, of the Bureau in a single phrase, I would say that the single motive of those who were instrumental in its organization and its maintenance was to provide an effective agency of citizen inquiry - to make the information obtained concerning the great business in which citizens are interested available for intelligent coöperation. The principles fundamental to the work of the Bureau are the principles fundamental to Democracy, viz:-

That the end of public business is public welfare.

That there is a non-political administrative and technical side as well as a political side to public business.

That whatever direct part the people may play in politics, the administration of public business must be conducted through authorized agents.

That a public administrative officer or agent is a public trustee.

That actions to enforce fidelity, economy, and efficiency of public trusts depends on evidence.

That the effective use of evidence in the enforcement of public trusts depends on the availability of this evidence to the trust beneficiary - the people.

The fundamental assumption of the programme of the Bureau is an organic part of our public law, namely, that the trust beneficiary (the citizen) may at all times freely inquire into the accounts of his trustee (the officer); that this is an essential part of minding his own business. As an organized agency, the Bureau relies on the common law and statutory right of access to public records. The questions we ask are: 
What records or evidence of transactions are kept by our trustees and public servants?

What may be learned from these records?

What is the story told with respect to fidelity, economy, and efficiency in the administration of the public trust?

What information necessary to intelligent judgment with respect to trusteeship is lacking?

In so far as results are unsatisfactory, is this due to the malfeasance, misfeasance and nonfeasance of public servants and how much is due to conditions for which the people themselves are responsible?

What political or administrative acts are necessary to the removal of conditions adverse to fidelity and efficiency of municipal officers and employees; and what changes in organization, what changes in methods and procedure, must be effected in order that our trustees may conduct our business with greatest economy, and efficiency.

THE WORK OF THE BUREAU OF MUNICIPAL RESEARCH

Four years ago a definite plan of citizen inquiry was formulated. Three years ago one citizen of New York became so far interested in this plan, in the possibilities of shaping opinion and directing coöperation through exact knowledge, that he undertook personally to support the plan as an experiment. Two years ago the original plan had become a conviction and three citizens of New York undertook to guarantee the funds necessary to supSystematic port of a vigorous agency of citizen inquiry. inquiry for The Bureau of Municipal Research was facts formally incorporated. One hundred and fifty thousand dollars has been spent in acquiring information concerning the great problem of public business in the city of New York, - about one dollar for each three thousand spent by the city during the period under 
review. The possibility of future accomplishment and of future citizen influence when the citizen body is actuated by a knowledge of facts, the profits which may accrue from an independent non-political citizen agency which may continue to cumulate institutional experience and make this available to enlightened citizenship, is before you.

Investigation has demonstrated beyond question that most of our municipal employees as individuals are serious in their work and have the city's welfare at heart; investigation has quite as conclusively proved that results which are unfavorable have usually proceeded from institutional methods and practices for which individuals in the service are not to be held responsible; that official incompetence has usually been due to the same condition which has caused citizenship to be ineffective, viz., to lack of the institutional means through which adequate information might be obtained. Citizen, officer, and the Methods of municipal employee have been constantly making facts handicapped by your neglect to "mind your available own business." For this reason the Bureau has undertaken to place the result of inquiry in the hands of officers, in order that methods which have seemed to encourage infidelity, and that practices which seemed to have produced waste and inefficiency might be corrected before these practices and results were made public. In other words, realizing that true democracy consists in intelligent coöperation between citizens and those elected or appointed to serve, it is hoped that the intelligence gained through systematic and independent citizen inquiry might be used by the mayor, the comptroller and heads of departments to correct abuses concerning which a citizen might complain, without waiting for the fortuitous circumstance a change in administra- 
tion. That is, it was thought that, under the conditions present, better results might be obtained through intelligent coöperation than through political upheaval based on partisan ignorance; that the problem of administration of a great city at the best is a most difficult task and that it is the duty of the citizen quite as much as the duty of the officer to assume responsibility for the constructive side of government.

\section{A CONSTRUCTIVE PROGRAMME}

Notwithstanding frequent assertions to the contrary on the part of those who have circulated false reports, or who, without inquiry, have accepted such report as true, "muck-raking" is no part of the work of the Bureau of Municipal Research. By far the greater part of the information obtained has not as yet been formally reported, for the reason that it was found that constructive action might be obtained by informally reporting conditions to administrative heads. A considerable number of our most important reports are still unpublished by reason of an expressed desire on the part of those in authority and a manifest disposition to use the suggestions effectively for "Muck-raking" constructive ends and to correct defects no part of the in administrative methods before the conBureau's work ditions to be remedied were given out. It is assumed that whatever the political faith and whatever the political faction represented in an office, the incumbent, as trustee, should be permitted to take credit for instituting measures to make more effective the administration of his trust rather than be placed in the position of being publicly criticised for infidelity and official neglect, due to methods inherited from the past; that when informed of infidelity and inefficiency in the service and of waste in management there can be but one result, 
namely, the use of the authority and power to correct these conditions; that the conditions which have made for bad government have been primarily an unintelligent citizenship and lack of means for obtaining a prompt, full, and accurate knowledge of the affairs.

\section{THE WORK OF REORGANIZATION IN PROGRESS}

As a result of popular opinion based on occasional disclosures of malfeasance and misfeasance in office, the powers of the comptroller have been enlarged until in administrative and financial importance this office is second to none in government. For half a century the comptroller of the city of New York has had powers adequate to devise, install, revise, and correct the methods of accounting and reporting and the administrative business

Powers unused practices of the city of New York - to made operative

bring them up to a standard as high as that of any private corporation. Notwithstanding this fact, at the time Comptroller Metz took office he was helpless to administer because there had not been established in his own office methods whereby he might inform himself even as to the most essential facts pertaining to the business of the city. There were no records in the city from which he might obtain accurate information as to the justice of claims presented, either for service rendered or for goods delivered. There was no method by means of which the fidelity of employees having the custodianship of millions of dollars' worth of supplies and materials and the care of great properties, might be determined. There were no records by means of which accurate information might be obtained as to the cost of operating and maintaining the various functions and activities for which the annual budget was voted. The only controlled accounts were appropriation and fund 
accounts and these could not readily be proved as to their accuracy. The accounts of departments were set up on the basis of 'vouchers drawn; the accounts of the comptroller were set up on the basis of warrants signed; the accounts-current of the chamberlain were prepared and rendered to the comptroller on the basis of warrants paid; the accounts-current of the chamberlain were reconciled with much difficulty, but no attempt was ever made to reconcile the accounts of the departments with those in the comptroller's office. Liabilities to the amount of millions of dollars were not entered on the city's books; no accounts were kept of properties owned; comptroller after comptroller had outlived his official term, with full power to correct and with practically no results in the revision of business methods. This had not been due to official carelessness, but due to the fact that the business of the city had become so encumbered and involved that a large part of the official term expired before a basis for intelligent judgment could be arrived at; and then the momentum of the institution, with its thousands of employees whose customary method of doing business must in a measure be interfered with, was so great that when attempts were made by individual officers and employees to correct, the end of an official term or a change affecting the prestige of those who sought to improve was made the opportunity for sliding back into the old groove.

During Mayor McClellan's first administration he drew attention to the unsatisfactory condition of the city's finances and accounts, and appointed a commission to report with recommendations. The powers of accounting revision lay with the comptroller. Comptroller Metz was selected on the platform of "a business man for a business office" and definitely promised "a business administration." In so far as the Bureau may claim 
credit for any change which has been made in administrative methods and procedure, it is for spending long coöperation hours of hard labor in finding out the facts, of official for assistance in getting before Mayor heads

McClellan, heads of administrative departments, and the citizenship of the city a statement of conditions to be corrected; for coöperation with Comptroller Metz and his official staff; for aid and support in the preparation of plans; for its part in conferences with the comptroller, the mayor and heads of departments; for work on committees appointed by the comptroller, the mayor, and heads of departments, who have had before them methods and procedure, responsibility for the adoption of which these officers have definitely assumed. Whatever assistance may have been rendered in the preparation of plans, it is to be remembered that the adoption of these plans and changes in procedure are official acts, and not the acts of a non-official citizen body. It is further to be remembered that responsibility for these changes is official responsibility.

During the last two years the office and the work of the Commissioners of Account has been completely reorganized; this branch of the executive organization has been materially strengthened. During the last two years, Comptroller Metz, assisted by Mayor McClellan and the heads of departments, has been working out a complete change in methods, designed to enable citizens and officers to think and act intelligently. A uniform system of accounts is now in process of installation in all departments New methods to take the place of the chaos of methods and procedure which heretofore has prevailed. In Deinstalled

cember, 1907, installation was begun along these lines in four of the large departments. During the summer of 1908 a central system of accounting control 
was devised by a special staff of experts appointed by Comptroller Metz and responsible to him for this work. In September, 1908, installation was begun in the department of finance by the introduction of a method of control over the signing and dispensing of warrants. The next step was taken in November, with the introduction of central control over certification and audit of vouchers. January I, I909, the books and documents required for a complete uniform system of disbursements accounts were placed in the accounting offices throughout the city, including the department of finance.

The seriousness and magnitude of this undertaking cannot be overestimated. A complete change has been made in the accounts of the department of finance by which control may be exercised over department appropriations, bond funds, contracts, open market orders, pay-rolls, stores, expense accounts, and construction

The need for citizen support accounts of one hundred different accounting offices, comprehending almost the full range of business activities and involving changes of institutional customs and habits of thousands of municipal employees. This is an undertaking that requires the fullest support that citizen coöperation and executive action can give. While Comptroller Metz has assumed official responsibility for these changes, what the citizens of the city of New York should realize is the fact that the comptroller and the mayor and the heads of departments are their trustees; that this is not the business of these officers, but the business of a corporation of which every citizen is a member; that as citizens you owe it to your officers and servants of all times, to keep fully informed about the business of this city; that this is your business, and without this information you cannot "mind your own business." 
THE CONTINUING NEED FOR AN INDEPENDENT CITIZEN AGENCY

The needs of government are largely business and not political needs. In the past it has been assumed that charter powers and "good" men were the only elements essential to the conduct of the business of a great public corporation. The army of employees, the methods and

Needs of government business needs equipment needed to make this army efficient, have been lost sight of. Without an appreciation of the administrative problem, without concrete knowledge of methods, equipment, or results, citizen organizations, publicists, and the press have assumed to reach conclusions, to express opinions, and to formulate these into constitutional and administrative law. Without knowledge either as to the organized agencies of public business or as to personal qualifications, without knowing what had been accomplished or what had been left undone, citizens have assumed to elect and depose, institute and repeal. It has been only recently that the thought has become current that the problem of administration of public corporate business is just as exacting, requires as great ability and as close application to assure success, as the problem of private corporate administration; that in large measure public business is administrative and nonpolitical; that the success of public administration depends on ability intelligently to direct and control the millions of details rather than ability to organize and crystallize popular opinion in support of political theories.

A more direct and forceful expression of this conviction has never been uttered than by Governor Hughes. The continuing need for an agency of citizen inquiry has been 
clearly defined by him. The sincerity of his statement A citizen's busi- was the more convincing when during the ness as defined closing hours of the last campaign he deby Governor parted from his tour of vote-getting to Hughes

accept an invitation to speak at the Budget Exhibit which was being held in the city of New York. An excerpt from his address is here given, not because of its reference to the work of a particular citizen organization, but because it may be accepted as an authoritative expression of a new view of citizen responsibility.

"I have come here," said Governor Hughes, "not to make a partisan speech. I have come from a desire to show interest in a movement in which all our citizens, irrespective of party, are deeply concerned. Whatever may be our party, after the issue the vast majority of our citizens are sincerely desirous to have an economical and efficient administration of our government. What we desire more than anything else is to get at the actual facts. I have no patience whatever with indiscriminate censure of public officials. I have every desire that study and investigation should precede action and that in all these important matters we should diligently strive to know the truth and to work together with the fullest degree of coöperation to improve our system of administration. As you know, I believe most thoroughly in 'home rule.' I have sought in many ways to show my desire that the principles of 'home rule' should be maintained. One thing that has struck me more than anything else during the past few years is the very large number of our citizens who in an unofficial way, but none the less effective way, are endeavoring to get at the facts regarding state and local administration, and to make a genuine contribution to progress.

"We are here under the auspices of a bureau which, 
I believe, in the character of its investigations to aid administration in this city marks one of the most important movements of recent years. The Bureau of Municipal Research is striving to get at the facts in an honorable, straightforward way, and is striving to present them so that they will be intelligently comprehended. This Budget Exhibit, a method of presenting in an attractive and forcible way the facts regarding our city life, is an important advance over the old methods of circulating information. . . . It is important not only to insist upon honesty and impartiality, but also the highest degree of efficiency. I do not sympathize with those who say that we cannot expect to have our public business conducted on as honest and efficient a basis as is private business. Whatever our attitude toward government may be, there is a wide sphere in which government must act. That sphere is extending. The necessary activities of state and city are extending. What can be done to further the highest degree of efficiency presents the most serious tests of our institutions and we must derote ourselves in the future to the solving of these problems in an intelligent and thorough-going manner. Not for political capital! Not for its own sake! I believe in quiet effective work which gets patiently at the facts and presents them to the intelligent judgment of the community. Then we can stand together and insist upon reforms the facts justify. We have had during the past years just preceding those when most of us came upon the public stage a splendid illustration of sacrifice and heroism and devotion to the interests of the country.

"We have had an illustration of the fact that if we are ever threatened by foreign powers, our young men would rush from their work with a sincere desire to serve the interests of the country. We must never forget that the 
same flag floats over the capital at Albany and the City Hall of New York, and so often as intelligent appeal is made we may expect the same patriotic service in relation to the official management of state and city. We have thousands of men who are giving faithful service in public employment. Don't make the mistake of making every man who holds a public office feel that he is considered dishonest, - because he is serving in a public capacity that the presumptions are against him.

"If we want good service we must vigorously criticize unfaithful service. And if we are going to have good results we must hold up the hands of the official who is trying to do his duty. In this city and in the state and in our various local organizations throughout the state we have a great number of men who are putting in their time and best work in the endeavor to do the business allotted to them in the most efficient way. We can aid them by insisting on standards which have been uplifted for a business-like administration, by holding up these standards and securing the general opinion of the public in favor of maintaining an administration based on real facts of the sort accepted in private business. Don't be cynical. We can have just what we want if we keep at it faithfully and expeditiously. This exhibit represents an enormous amount of work on the part of men who are trying to get at the facts, not for any selfish purpose, not for any censorious purpose, not for political or partisan purpose, but for honest government."

One thought I would leave with you, viz., that the ability of the people to rule must depend on the intelligence of public opinion. Public opinion is the force which governs. It determines our morals; it controls us in our daily lives; it makes for individual success and failure; it is the law of business, public and private; it repeals constitutions, 
annuls statutes, and reverses decisions of courts without going through legal forms and conventions; it decides Enlightened what the government shall be and underpublic opinion take; it elects our officers, approves and the desideratum disapproves their acts. In a democracy, public opinion wields the sceptre. Whether it shall be used to crucify truth and sanctify falsehood, or for ends of social justice, whether officers and agents shall be successful in the administration of our great public trusts, whether funds and properties shall be faithfully and effectively employed for the welfare of the people, must depend on the intelligence of this opinion. In calling your attention to the continuing need for an independent, non-partisan agency of citizen inquiry through which citizenship may be made effective, through which you may be systematically informed of the details of public business, through which the force of popular opinion may be used for community welfare, we are asking you to mind your own business. 

. 




\section{University of British Columbia Library \\ DUE DATE}

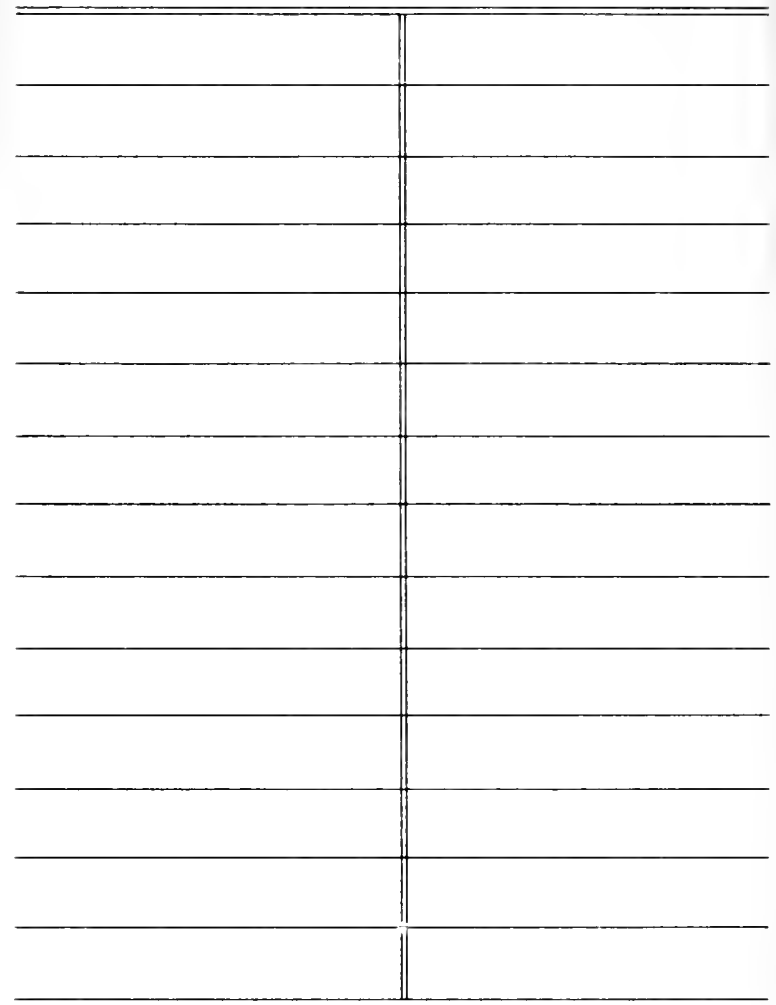

FORM 310 


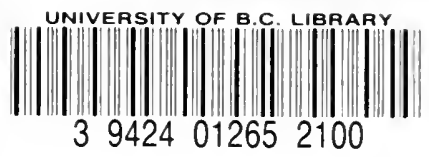




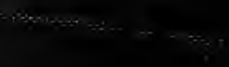

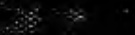

$\therefore \quad \cdots$ 